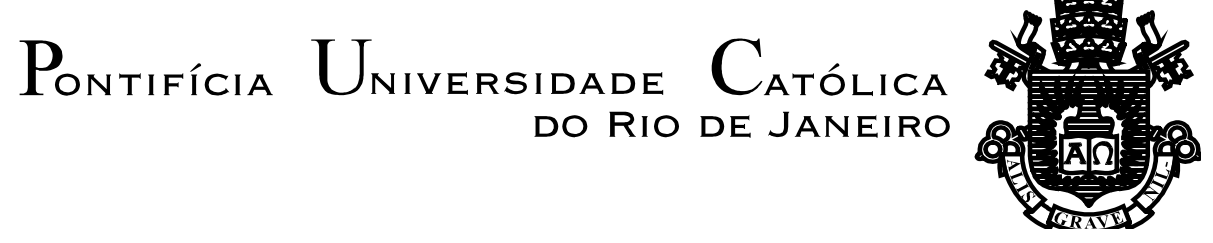

Maria de Lourdes Souza

\title{
Do Córrego ao Rio, o percurso de quem lê e escreve no chão de sua terra a própria história e a de sua gente
}

\section{Dissertação de Mestrado}

Dissertação apresentada como requisito parcial para obtenção do grau de Mestre pelo programa de Pós-Graduação em Literatura, Cultura e Contemporaneidade do Departamento de Letras.

Orientadora: Prof $\stackrel{\text { a }}{\text {. Rosana Kohl Bines }}$ 
Pontifícia Universidade Católica

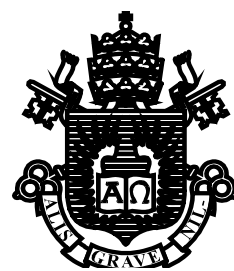

Maria de Lourdes Souza

\begin{abstract}
Do Córrego ao Rio, o percurso de quem lê e escreve no chão de sua terra a própria história e a de sua gente
\end{abstract}

Dissertação apresentada como requisito parcial para obtenção do grau de Mestre pelo Programa de PósGraduação em Literatura, Cultura e Contemporaneidade do Departamento de Letras do Centro de Teologia e Ciências Humanas da PUCRio. Aprovada pela Comissão Examinadora abaixo assinada.

Profa. Rosana Kohl Bines

Orientadora

Departamento de Letras - PUC-Rio

Profa. Daniela Gianna Claudia Beccaccia Versiani

Departamento de Letras - PUC-Rio

Profa. Maria Cristina Cardoso Ribas

UERJ

Profa. Denise Berruezo Portinari

Coordenadora Setorial do Centro de Teologia

e Ciências Humanas - PUC-Rio

Rio de Janeiro, 01 de abril de 2014 
Todos os direitos reservados. É proibida a reprodução total ou parcial do trabalho sem autorização da universidade, da autora e do orientador.

\section{Maria de Lourdes Souza}

Graduou-se em Letras pela PUC-Rio, habilitação em Licenciatura em Letras/Português e Literaturas de Língua Portuguesa, em 2011. Obteve o título de Mestre pelo Programa de Pós-Graduação em Literatura, Cultura e Contemporaneidade do Departamento de Letras da PUCRio, em 2014. Em 1998 lançou o livro "Dicionário de Lembranças", pela Editora Contemporânea. Publicou contos em quatro antologias editadas pela GANG Edições. É Coordenadora da Casa de Memória e Cultura do Córrego dos Januários, na comunidade do Córrego dos Januários-Inhapim/MG.

Ficha Catalográfica

\section{Souza, Maria de Lourdes}

Do Córrego ao Rio, o percurso de quem lê e escreve no chão de sua terra a própria história e a de sua gente / Maria de Lourdes Souza ; orientadora: Rosana Kohl Bines. - 2014.

195 f. : il. (color.) ; $30 \mathrm{~cm}$

Dissertação (mestrado)-Pontifícia Universidade Católica do Rio de Janeiro, Departamento de Letras, 2014.

Inclui bibliografia

1. Letras - Teses. 2. Clubinho de leitura. 3. Contador de história. 4. Comunidade. 5. Formação de leitor. 6. Tradição oral. 7. Transformação. I. Nines, Rosana Kohl. II. Pontifícia Universidade Católica do Rio de Janeiro. Departamento de Letras. III. Título. 
Para meus pais, Bolivar Martinho de Souza e Floripes Cândida de Souza (in memoriam), e para todos os nascidos no Córrego dos Januários, minha terra. 


\section{Agradecimentos}

À minha orientadora professora Rosana Kohl Bines, pela confiança e parceria cuidadosa na construção deste trabalho.

À CAPES e à PUC-Rio, pelos auxílios concedidos, sem os quais este trabalho não poderia ter sido realizado.

Aos professores e funcionários do Departamento de Letras da PUC-Rio pela atenção e conhecimento partilhado.

À Denise Sampaio Gusmão pela força e a delicadeza com que vem me incentivando e apoiando na aventura por novos mundos, e concretizando sonhos.

À Luana pela confiança e amizade que permitiram abrir para mim as portas para o conhecimento da literatura e tudo de bonito que veio depois.

À Natalie, minha filha do coração com quem eu dividi muitas histórias, e que tanto tem me ensinado.

À Hilda Sampaio Gusmão pela recepção sempre alegre na casa que tem sido meu refúgio nos momentos mais delicados.

À professora Sonia Kramer, pelos muitos ensinamentos e pelo olhar delicado e amoroso para o que venho fazendo e pensando.

À professora Solange Jobim e Souza por acompanhar, respeitar e valorizar os passos desta narrativa.

À professora Leila Mathias, pela forma carinhosa pelo apoio na reta final deste trabalho.

À Deborah Alexander por ter me dado o livro "O dom da história", de Clarissa Pinkola Estès, que desencadeou um sem fim de ações, pela acolhida e pela amizade sempre tão presente e verdadeira.

Ao Marcos Giácomo, pela ajuda na hora necessária e por incentivar os voos.

Ao Madson, Renata, Luisa, Rose, Laércio, Rômulo e Cleonice, os petropolitanos que nos proporcionaram lindos momentos na Casa de Memória e Cultura do Córrego dos Januários. 
À professora Eliana Yunes pelas oportunidades de trabalho e pelos muitos aprendizados sobre livros, leituras e leitores.

À professora Marília Rothier Cardoso pela oportunidade de ir para Rosário/Argentina, onde tive aprendizados imensuráveis e inesquecíveis.

À professora Sandra Contreras, por tão bem me receber na Universidad de Humanidades y Artes na Universidad Nacional de Rosário/AR.

Ao professor Gerardo Kahan pela orientação preciosa na Universidad de Humanidades y Artes na Universidad Nacional de Rosário/AR.

Aos professores e funcionários da Escuela de posgrado, Escuela de Letras e da Escuela de Ciências de la Educación da UNR, pela atenção dispensada.

À Biblioteca Popular Cachilo, Biblioteca Popular Juan Bautista Alberdi, Semillas de Futuro y Biblioteca Independiente para el pensamiento amplio, crítico y poético, Biblioteca Popular Y Municipal Jose Hernandes, Biblioteca Pedagógica Eudoro Dias, ao Instituto Superior del Profesorado $N^{o} 16$ "Dr. Bernardo A. Houssay" e ao Centro para una Cultura Alternativa y Popular y la Bibliomóvil, Biblioteca Municipal Mariano Moreno, por tanto me ensinarem sobre livros e responsabilidade social.

À Circe Guedes, por me acolher em sua casa rosarina, pela alegria e pelas longas conversas.

À Clea Oliveira por me facilitar o caminho até Rosário.

A Graciela Diez, Mariela Aspiazu, Laura Borletto, Brenda Calabrasa, Silvina Vittar, Luciana Andrea Fernandez e Maria Elena Micheli por me ensinarem muito sobre respeito à cultura e sobre generosidade.

À escritora Beatriz Actis, pelo saber compartilhado com alegria.

Ao Luiz, à Maíra e Aline pela companhia na UNR e nas descobertas rosarinas.

Ao Sávio Roberto, pelas lindas fotografias.

À equipe Clubinho de Leitura: Adélia, Branca, Dayane, Edervanio, Edilaine, Saulo, Rita, e Zilda, pela parceria no sonho de levar adiante os projetos da Casa de Memória e Cultura.

À minha família por ser parte dessa história.

A toda a comunidade do Córrego dos Januários, por acompanhar e ser parte de todo o fazer dessa dissertação, e pelas orações. 


\section{Resumo}

Souza, Maria de Lourdes; Bines, Rosana Kohl (Orientadora). Do Córrego ao Rio, o percurso de quem lê e escreve no chão de sua terra a própria história e a de sua gente. Rio de Janeiro, 2014, 195p. Dissertação de Mestrado - Departamento de Letras, Pontifícia Universidade Católica do Rio de Janeiro.

O propósito desta dissertação é narrar a trajetória cultural de uma leitora e sua comunidade de nascimento, o Córrego dos Januários, área rural do município de Inhapim, leste de MG, bem como produzir um relato reflexivo sobre as ações desenvolvidas no Clubinho de Leitura, projeto de formação de leitores realizado por voluntários, que existe desde 2003. O primeiro capítulo aborda a tradição dos contadores de histórias, um passeio pelos campos da infância, apresentando alguns contadores e algumas histórias de tradição oral recolhidas junto a moradores da comunidade do Córrego dos Januários, ao longo dessa pesquisa. $\mathrm{O}$ segundo capítulo refaz a trajetória cultural de Maria de Lourdes, autora desta dissertação, entremeada com a história de transformação do povoado onde nasceu, sua gente, sua terra. O terceiro capítulo trata das atividades realizadas pelo Clubinho de Leitura e sua repercussão na comunidade. O quarto capítulo traz o relato da pesquisa realizada durante o mestrado-sanduiche na Facultad de Humanidades y Artes - Universidad Nacional de Rosário (UNR), na cidade de Rosário/Argentina, apresentando alguns projetos de promoção de leitura com os quais a pesquisadora teve maior aproximação. O último capítulo propõe uma reflexão sobre questões sociais e processos de transformação e aprendizado com os olhos no futuro.

\section{Palavras-chave}

Clubinho de leitura; contador de história; comunidade; formação de leitor; tradição oral; transformação. 


\section{Resumen}

Souza, Maria de Lourdes; Bines, Rosana Kohl (Director de Disertación). Del Córrego al Rio, el recorrido de quien lee y escribe en el suelo de su tierra la propia historia y la de su gente. Rio de Janeiro, 2014, 195p. Disertación de Maestria - Departamento de Letras, Pontifícia Universidade Católica do Rio de Janeiro.

El propósito de esta disertación es narrar la trayectoria cultural de una lectora y su pueblo de nacimiento, el Córrego dos Januários, región rural de la municipalidad de Inhapim, al este de Minas Gerais, bien como producir un relato reflexivo sobre las acciones desarrolladas en el Clubinho de Leitura, proyecto de formación de lectores realizado por voluntarios, que existe desde 2003. El primer capítulo aborda la tradición de los cuentacuentos, un paseo por los campos de la infancia, presentando algunos de los cuentistas y algunas historias de tradición oral que fueron recogidas junto a los que viven en el pueblo de Córrego dos Januários, a lo largo de esta investigación. El segundo capítulo rehace la trayectoria cultural de Maria de Lourdes, autora de esta disertación, intercalada con la historia de transformación del pueblo donde ha nacido, su gente, su tierra. El tercer capítulo trata de las actividades realizadas en el Clubinho de Leitura y su repercusión en el pueblo. El cuarto capítulo trae el relato de la investigación realizada durante el "mestrado-sanduiche" en la Facultad de Humanidades y Artes - Universidad Nacional de Rosario (UNR), en la ciudad de Rosario/Argentina, presentando algunos proyectos de promoción de lectura a los cuales la investigadora más se acercó. El último capítulo propone una reflexión sobre las cuestiones sociales y procesos de transformación y aprendizaje con los ojos en el futuro.

\section{Palabras-clave}

Clubinho de Leitura; cuentacuentos; pueblo; formación de lectores; tradición oral, transformación. 


\section{Sumário}

1. Introdução

2. Um dedo de prosa: voltando aos campos da infância

3. Por parte de mãe $\quad 51$

3.1. Bolivar e Floripes, os meus pais 58

3.2. De professora a escritora, muitos caminhos 61

3.3. Volta ao Córrego em três dias: uma aventura em busca da
memória

3.4. Maria de Lourdes - a Toquinha, e a Universidade 76

4. O livro, a leitura e as tecnologias: novas leituras, novas histórias. 81

4.1. Gratidão: dar, receber, retribuir - O Clubinho de Leitura 91

4.2. O Córrego chega ao Rio, o Clubinho cruza montanhas... 95

4.3. O Clubinho de Leitura de sala nova! 102

$\begin{array}{ll}\text { 4.3.1. Temos visita! } & 104\end{array}$

5. Navegando por outros rios: bibliotecas populares de Rosário 134

5.1. Biblioteca Popular Cachilo 141

5.2. Biblioteca Popular Juan Bautista Alberdi 147

5.3. Biblioteca Independiente para el Pensamiento Amplio, Crítico y Poetico

6. Reflexões e caminhos 162

6.1. Direito de sonhar e de realizar 170

$\begin{array}{lr}\text { 7. Considerações finais } & 184\end{array}$

$\begin{array}{lr}\text { 8. Anexos } & 189\end{array}$

9. Referências Bibliográficas 191

9.1. Referências Eletrônicas 194 


\section{Lista de figuras}

Figura 1: O Córrego dos Januários 18

Figura 2: Tio Geraldo Domingos $\quad 19$

Figura 3: Casa do meu avô onde ouvi muitas histórias 19

Figura 4: versos lembrados por Zilmar 27

Figura 5: História de Zezinho e Mariquinha 1

Figura 6: História de Zezinho e Mariquinha 2

Figura 7: História de Zezinho e Mariquinha 3

Figura 8: História de Zezinho e Mariquinha $4 \quad 29$

Figura 9: Antônio Silvino: vida, crime e castigo 37

Figura 10: Antônio Silvino: vida, crime e castigo 2

Figura 11: Antônio Silvino: vida, crime e castigo 3

Figura 12: Seu Genorinho dando entrevista na E. E. Alberto Azevedo 39

Figura 13: Meu rencontro com Seu Genorinho e a filha Maria das Graça (Didi)

Figura 14: Seu Zé Barba (foto de Madson José) 43

Figura 15: Toquinha no balanço 51

Figura 16: Bolivar $\quad 58$

Figura 17: Floripes 58

Figura 18: Livro "Escrava de um dever" 59

Figura 19: Bolivar e Floripes se casam 60

Figura 20: Floripes na janela, Marco, Argeu, Márcia (netos), e Amauri 60

Figura 21: Toquinha, Natalie e Luana 62

Figura 22: A biblioteca de Luana, a primeira a que tive acesso livre. (Foto de Natalie)

63

Figura 23: Livro "Dicionário de Lembranças" 65

Figura 24: Casa da Tia Fiinha (Foto de Denise Gusmão) 68

Figura 25: Tia Fiinha 69

Figura 26: Brenno, Denise, Deborah, Seu Agenor, Deodato e Cláudia 71

Figura 27: Juca segurando a dália, Maria de Lourdes narrando a cidade e Brenno filmando (Foto de Denise Gusmão 71

Figura 28: Matéria publicada no jornal Oficina de ldeias, de Inhapim $\quad 74$

Figura 29: Cátedra UNESCO de Leitura PUC-Rio 78

Figura 30: Contação de histórias na Sala de Leitura Educagente, por Rute Casoy

79

Figura 31: Toquinha, Denise e o varal de histórias 82

Figura 32: Casa de Memória e Cultura do Córrego dos Januários, em dia de visita

Figura 33: Toquinha sendo entrevistada por alunos da Escola Municipal Elias Januário (Foto de Denise Gusmão)

Figura 34: Marlene e Dayane lendo o livro "Dicionário de Lembranças" (Foto de Denise Gusmão)

Figura 35: Toquinha na inauguração da Casa de Memória e Cultura (foto de Ana Andrade)

Figura 36: Sara lendo (Foto de Sávio) 91

Figura 37: A primeira mala de livros 92

Figura 38: O Clubinho de Leitura na sua primeira casa 93 
Figura 39: As irmãs Marlene, Teresinha, Dorvalina, Isabel e Maria de Lourdes

Figura 40: A Casa, herança de nossos pais (Foto de Denise Gusmão) 95

Figura 41: Postal com mensagem de Elizete 97

Figura 42: Resposta de Bárbara para Elizete 98

Figura 43: Nosso grupo encontra Gabriela Gibrail, então curadora da FLIPinha (2009, p. 166)

Figura 44: Representantes do Clubinho e participantes da oficina colocando seus postais em nossa caixa de correio Evento PUC pela PAZ. (2009, p. 167)

Figura 45: Postal enviado ao Clubinho pela escritora Lygia Bojunga. (2009,

Figura 46: Postal de Sonia Kramer para o Clubinho (2009, p. 237) 100

Figura 47: Mensagem de Solange Jobim. (2009, p. 137) 100

Figura 48: Mensagem/carta de Eliana Yunes 101

Figura 49: Sala do Clubinho no dia da inauguração 102

Figura 50: Primeiros visitantes do Clubinho (Fotos de Ana Andrade) 102

Figura 51: Dayane lendo para as crianças 103

Figura 52: Crianças ouvindo a história de Dayane (Fotos de Sávio) 103

Figura 53: Maria Eduarda e Sara 1

Figura 54: Maria Eduarda e Sara $2 \quad 104$

Figura 55: Caio e Sandro lendo no Clubinho 104

Figura 56: A Velhota Cambalhota na Casa de Memória e Cultura 105

Figura 57: A Velhota Cambalhota e Maria Aparecida, na Casa de Memória e Cultura 106

Figura 58: Olha a ciranda... 106

Figura 59: Hoje tem palhaçada, tem sim senhor! 107

Figura 60: Na Escola Municipal Elias Januário!!! 107

Figura 61: Nenê, Adriana, Cacareco, Marmelada, Mariinha, Zito e Zilmar, todos vão à escola... 107

Figura 62: Espetáculo "Depois da Chuva" 1 (foto de Mariana Rocha) 109

Figura 63: Espetáculo "Depois da Chuva" 2 (foto de Mariana Rocha) 109

Figura 64: Espetáculo "Depois da Chuva" 3 (foto de Mariana Rocha) 109

Figura 65: Fomos ao teatro! Jupira, Adélia e Gustavo 109

Figura 66: No teatro Casa Laboratório 111

Figura 67: Tem prosa da boa. 111

Figura 68: Dulcinéia conta sua experiência... 111

Figura 69: Os amigos do Andança na casa de Edervanio 112

Figura 70: Espetáculo "Direções do Céu" na Casa de Memória de Cultura 1 (Foto de Luisa Alves)

Figura 71: Espetáculo "Direções do Céu" na Casa de Memória de Cultura 2

Figura 72: Espetáculo "Direções do Céu" na Casa de Memória de Cultura 3

Figura 73: Oficina de cartões ecológicos 113

Figura 74: Oficina de cartões ecológicos 1

Figura 75: Oficina de cartões ecológicos 2

Figura 76: Oficina de cartões ecológicos 3 (Fotos de Sávio) 115

Figura 77: Oficina de cartões ecológicos 4 (Foto de Sávio) 116

Figura 78: Roda de choro e de alegria $1 \quad 117$ 
Figura 79: Roda de choro e de alegria 2

Figura 80: Oficina de percussão do Professor Alegria 1

Figura 81: Oficina de percussão do Professor Alegria 2

Figura 82: Olhando a banda a dançar $1 \quad 118$

Figura 83: Comidas gostosas para arrecadar fundos 118

Figura 84: Professora Lúcia e os alunos com o livro de mão em mão 122

Figura 85: João Laender lendo para os colegas 122

Figura 86: Leonardo lendo para os colegas 122

Figura 87: Livro "Língua de trapos", de Adriana Lisboa 124

Figura 88: Língua de trapos, papel e brincadeira 124

Figura 89: Crianças e obra de arte coletiva 124

Figura 90: Dia de Clubinho 1 (Foto de Sávio) 129

Figura 91: Dia de Clubinho 2

Figura 92: Casa de Memória e Cultura na UNEC-Caratinga/MG 130

Figura 93: Aun tenemos utopias... 134

Figura 94: Pedindo a bênção a Nossa Senhora do Rosário 135

Figura 95: Caixa de livros enviados às escolas argentinas pelo Plan Nacional de Lectura

Figura 96: Livro-álbum

Figura 97: Biblioteca Popular Cachilo 1

Figura 98: Biblioteca Popular Cachilo 2

Figura 99: Taller Beatriz Actis 143

Figura 100: Divulgação da Quermesse 145

Figura 101: La Cachilo te cuenta 1 (Foto de Victor Bobadilla) 145

Figura 102: Leitura ternura $\quad 145$

Figura 103: La Cachilo te cuenta 2 (Foto de Victor Bobadilla) 146

Figura 104: La kermess $\quad 146$

Figura 105: La Cachilo te cuenta no bairro de Ludueña 1

Figura 106: La Cachilo te cuenta no bairro de Ludueña 2 (Fotos de Victor Bobadilla)

Figura 107: Biblioteca JB Alberdi 147

Figura 108: Apresentação do livro-objeto de Graciela Diez 149

Figura 109: Toquinha e Graciela Diez 149

Figura 110: Graciela Diez e seu livro-objeto 149

Figura 111: Amanda Paccotti e Emilia Casadedio 150

Figura 112: Bibiana Oliva, Amanda Paccotti e Emilia Casadedio lendo seu conto

$\begin{array}{ll}\text { Figura 113: Logotipo Biblioteca Independiente } & 152 \\ \text { Figura 114: Biblioteca Independiente 1 } & 153\end{array}$

Figura 115: Paróquia Santa Catalina 153

Figura 116: Biblioteca Independiente 2

Figura 117: Conhecendo Biblioteca Independiente 155

Figura 118: Maria de Lourdes e Javier (Foto de Luciana) 156

Figura 119: Convite para trabalhos na Biblioteca 157

Figura 120: Obra coletiva $\quad 157$

Figura 121: Pintando o nome da Biblioteca 157

Figura 122: O aprendizado e a alegria do trabalho comunitário $1 \quad 158$

Figura 123: O aprendizado e a alegria do trabalho comunitário $2 \quad 158$

Figura 124: Dançando para celebrar 158

Figura 125: Todos somos um 158 
Figura 126: Centro para una Cultura Alternativa y Popular 159

Figura 127: Bibliomóvil 159

Figura 128: Biblioteca Municipal Popular y Popular Jose Hernandez 159

Figura 129: Oficina de Literatura $\quad 160$

Figura 130: Casa de Cultura Granadero Baigorria $\quad 160$

Figura 131: Quadro-negro com frases de Paulo Freire $\quad 161$

Figura 132: Marcelo (Foto de Denise Gusmão) 163

Figura 133: Marcelo, Rafaela e Dayane (Foto de Denise Gusmão) 164

Figura 134: Toquinha e Galeano no Auditório do RDC-PUC-Rio (Foto de Denise Gusmão) 166

Figura 135: Inauguração da Casa de Memória e Cultura, Antônio, João Donato, Julio e Mônica 181

Figura 136: Adriana e Eulália 181

Figura 137: Rosália e Sebastião (Fotos de Ana Andrade) 181

Figura 138: Inauguração da Casa de Memória e Cultura, Denise e Seu Genorinho 182

Figura 139: Inauguração da Casa de Memória e Cultura, Maria José, Virgínia, Betinho e Lucas

Figura 140: Inauguração da Casa de Memória e Cultura, Tio Cândido (Fotos de Ana Andrade) 182

Figura 141: Dayane, Toquinha, Saulo, Edervanio, Rita e Branca 183

Figura 142: Luis Humberto Soriano Bohórquez $\quad 185$

Figura 143: Luis Soriano e as crianças 187 
Não me iludo

Tudo permanecerá Do jeito que tem sido

Transcorrendo

Transformando

Tempo e espaço navegando

Todos os sentidos...

(Gilberto Gil) 


\section{1 \\ Introdução}

Este trabalho narra o percurso cultural da leitora e escritora Maria de Lourdes Souza, autora desta dissertação, e da comunidade do Córrego dos Januários situada na área rural do município de Inhapim, região leste de Minas Gerais. Faço uma reflexão sobre a repercussão e a relevância das atividades oferecidas no Clubinho de Leitura, projeto de formação de leitores criado em 2003, que vem realizando um trabalho de sensibilização para a leitura e o contato com distintas formas de arte, integrado à Casa de Memoria e Cultura do Córrego dos Januários. A Casa de Memória e Cultura, inaugurada em 30 de agosto de 2008, é resultado da ampla pesquisa de mestrado e de doutorado de Denise Sampaio Gusmão dentro do GIPS (Grupo Interdisciplinar de Pesquisa da Subjetividade), pelo Departamento de Psicologia da PUC-Rio, sob a orientação da professora Solange Jobim e Souza, e é hoje um lugar de ações culturais, de lida com a literatura oral e escrita e de encontros entre os próprios moradores e com visitantes de outras terras. Nela está resguardada a nossa história, os contos $e$ imagens de muitos januarenses e a biblioteca, o nosso Clubinho de Leitura.

$\mathrm{O}$ entrelaçamento entre a minha própria história e a história de transformação comunitária se dá porque meus aprendizados da leitura e da escrita me levaram a desenvolver ações que possibilitaram a recuperação da nossa memória histórica e cultural daquele meu lugar. Do meu encontro com a pesquisadora Denise Gusmão surge uma possibilidade de transformação que se deu com muita delicadeza e cuidado por parte da pesquisadora que, com sua sensibilidade e dedicação, escavou o solo de nossa memória nos ajudando a nos reconhecermos como atores do nosso próprio caminho.

No primeiro capítulo "Um dedo de prosa: voltando aos campos da infância", abordo a tradição dos contadores de histórias, fazendo um passeio pelo Córrego dos Januários da minha infância, apresentando alguns contadores e algumas histórias de tradição oral recolhidas junto a moradores da comunidade, ao longo do trabalho de pesquisa. Esse caminho percorrido tem como motivador a memória deixada pelas narrativas tradicionais que andavam por lá nos meus tempos de menina. O filósofo Walter Benjamin é quem me acompanha nesta fase da viagem, quem ancora o meu pensar. 
No segundo capítulo, "Por parte de mãe", refaço a minha própria trajetória cultural entremeada com a história de transformação do povoado onde nasci, minha gente, minha terra. São lembranças que permitem reconhecer os eventos que construíram a leitora e escritora que me tornei, que recuperam momentos sem os quais possivelmente a vida me levaria por outros rumos.

O capítulo terceiro "O livro, a leitura e as tecnologias: novas leituras, novas histórias", trata das atividades realizadas pelo Clubinho de Leitura e sua repercussão na comunidade, dos encontros e aprendizados. A professora e pesquisadora em educação, Sonia Kramer, me ajuda ao longo de todo esse caminho, e eu me apoio principalmente no conceito de Leitura como Experiência, que tem sido base para meus pensares e fazeres no mundo da leitura e do trabalho dos professores e suas escolas. Com Eliana Yunes, professora do Departamento de Letras da PUC-Rio e criadora da Cátedra UNESCO de Leitura PUC-Rio, eu busco um diálogo em que o livro, esse personagem silencioso e revolucionário, vai ocupando espaços e proporcionando amadurecimento.

O capítulo quarto "Navegando por outros rios: bibliotecas populares de Rosário", apresenta o relato de pesquisa realizada durante os três meses de mestrado-sanduiche na Facultad de Humanidades y Artes - Universidad Nacional de Rosário (UNR), na cidade de Rosário/Argentina. Essa experiência me deu a oportunidade de conhecer algumas bibliotecas populares e uma biblioteca que se identifica como independente, que são projetos realizados pelos próprios bairros, trabalhando na promoção de leitura e difusão da literatura. E pude entender o importante trabalho social que estes projetos desenvolvem nos respectivos bairros onde estão inseridos. A autora argentina Beatriz Actis me ajuda a navegar por essas terras.

O último capítulo "Reflexões e caminhos", traz uma reflexão sobre nosso processo de transformação comunitária e aprendizado, com os olhos no futuro. No diálogo engendrado com Boaventura de Souza Santos e com Eduardo Galeano, busco o entendimento sobre o nosso tempo, sobre questões sociais que nos perpassam, nos indagam, pedem solução.

Numa perspectiva etnometodológica, de pesquisa-ação, construo uma narrativa atenta aos conceitos de polifonia e dialogismo propostos pelo pensador russo Mikhail Bakhtin, com quem dialogo no sentido de perceber o papel do outro, que foram tantos, na realização do projeto com o qual vimos trabalhando 
desde 2001, o processo de criação da Casa de Memória e Cultura, que nos permitiu olhar para nós mesmos e nos abriu horizontes.

Além dos já citados, outros autores foram muito importantes no processo de produção desta dissertação como o psiólogo judeu nascido na Áustria Bruno Bettelheim e nosso grande educador, inspirador de uma legião de educadores, Paulo Freire, Frei Chico, um pesquisador da cultura popular do Vale do Jequitinhonha, o filósofo francês Paul Ricoeur e a professora e filósofa Jeanne Marie Gagnebin. A psicóloga americana Clarissa Pinkola Estés comparece como inspiradora de toda uma trajetória chamando minha atenção para as histórias populares e de família.

Para a recolha do material de pesquisa lancei mão de entrevistas gravadas em áudio e vídeo transcritas, fotografias e correpondência via e-mail e redes sociais. Além dos autores aqui nomeados, outros ainda comparecem dando suporte ao meu pensamento.

A narrativa que se segue é feita de retalhos de cores e espessuras imprecisas que compõem um tecido disforme, às vezes falho, às vezes frágil, revelando uma costura que deixa entrevisto a sua feitura coletiva; e essa é sua importância, seu valor, por ter sido feito a muitas mãos, estar carregado de muitas energias, e de ser único; nisso reside a beleza do que construímos como comunidade, como povo transformado e transformador. 


\title{
2 \\ Um dedo de prosa: voltando aos campos da infância
}

\author{
Minha mãe achava estudo \\ a coisa mais fina do mundo \\ Não é \\ A coisa mais fina do mundo é o sentimento. \\ Aquele dia de noite, o pai fazendo serão, \\ ela falou comigo \\ "Coitado, até essa hora no serviço pesado". \\ Arrumou pão e café, deixou tacho no fogo com água quente. \\ Não me falou em amor. \\ Essa palavra de luxo. \\ (Adélia Prado)
}

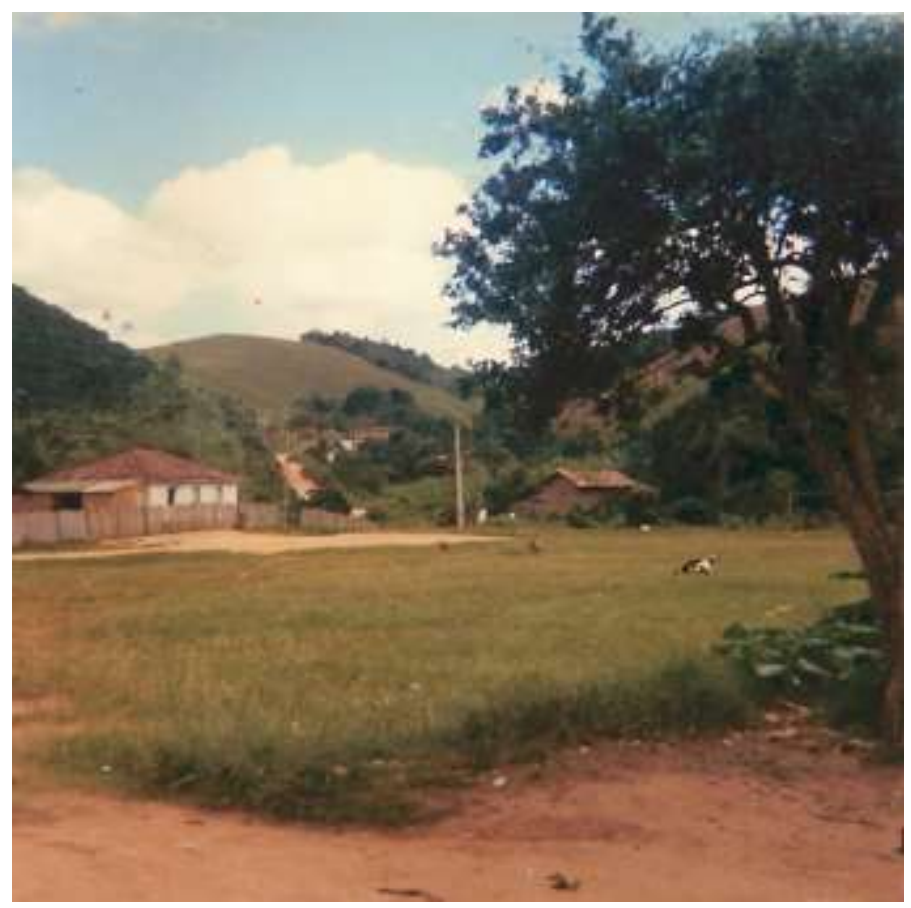

Figura 1: O Córrego dos Januários

Muitos anos atrás nascia eu, Maria de Lourdes, no Córrego dos Januários, uma pequena comunidade situada na área rural do município de Inhapim, interior do interior de Minas Gerais, onde, naquele tempo, não havia água encanada, nem luz elétrica. Cheguei ao mundo por mão de parteira, caçula de uma família de cinco filhas. Por Maria me batizaram, mas quem chega no Córrego dos Januários melhor perguntar por "Toquinha", ou não saberá nada de mim; minha irmã Terezinha diz que esse apelido surgiu quando eu era ainda muito pequena, por conta de um livro chamado "Histórias de Zé Toquinha", e que me achavam 
parecida com a figura da capa. Começaram a me chamar Toquinha, por brincadeira, e assim é até hoje.

Nasci na roça, cercada por montanhas que me separavam de tudo quanto era modernidade. Por lá, na minha infância, eu brincava de roda, tomava banho de córrego, ouvia histórias; muitas histórias. Eu não tinha livros, tinha contadores de histórias, e cresci cercada pelos personagens da literatura oral que chegaram a mim pela boca do povo, onde eu podia abusar do imaginário, do lúdico e criar meus próprios mundos.

Tio Geraldo Domingos, Seu Genorinho, Seu Carmo Felix, Seu Ismael, Tia Dina e Tia Inês gostavam de contar histórias. Dentre estes, meu tio Geraldo era o mais próximo. Eu e meus primos nos reuníamos quase todas as noites em volta dele aquecidos pelo calor do fogão a lenha, enquanto assávamos milho-verde na brasa. Quase todo dia as mesmas histórias, mas sempre outras. Tão bonitas! E tristes. Muitas eram engraçadas, outras compriiiiidas... O coração pulava no peito quando ele fazia longas pausas tragando seu cigarro de palha até quase queimar o bigode, em momentos decisivos da história.
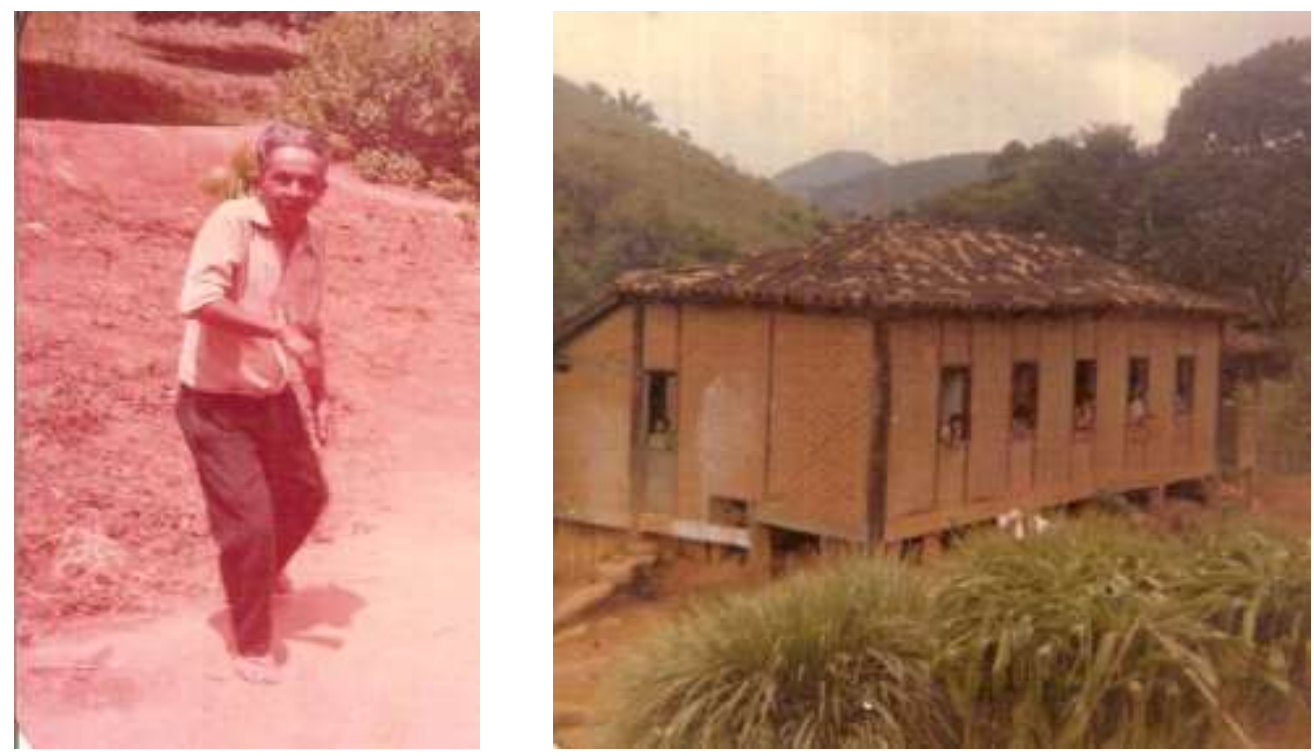

Figura 2: Tio Geraldo Domingos

Figura 3: Casa do meu avô onde ouvi muitas histórias

Dorvalina: uai, eu lembro do Tio Geraldo lá contando história pra nós todo dia. Tinha lá a cozinha, acendia o fogo lá no meio da cozinha, fazia biscoito, fazia pipoca... eu lembro de uma história do soldado da guerra, mas eu não sei, eu só lembro trechos.

Toquinha: soldado da guerra?

Dorvalina: que escutava os soldados quando vinham, aí punha o ouvido no chão e via que a cavalaria vinha longe, aí, mas eu não lembro da história toda mais. Eu lembro dessa da Mariazinha. 
Toquinha: ah, essa que eu gostaria que você contasse, porque essa eu tento lembrar e não consigo.

Dorvalina: A Mariazinha era uma menina muito boa, mas a mãe dela morreu muito cedo e o pai dela casou de novo. O pai dela casou de novo, mas casou com uma mulher muito má e a mulher judiava muito dela. Aí essa mulher começou a maltratar Mariazinha, mas o marido não sabia. Ele chegava à tarde e ela ia reclamar com o pai mas o pai não dava ideia não. Aí ela, ela tinha uma outra filha da mesma idade dela, mas ela não fazia com a filha dela o que ela fazia com a Mariazinha. Todo dia ela falava pra Mariazinha fazer serviço pesado e ela era muito pequena ainda. Aí um dia ela falou com ela assim: ó, hoje cê vai lavar essa roupa, vai passar essa roupa passadinha. Vai lavar e passar hoje. Ela pegou a trouxa de roupa e saiu chorando pela estrada pensando como que ela ia arrumar. Ela encontrou com uma velhinha e a velha falou assim: Por que cê tá chorando? Ah, eu tô chorando porque eu tenho que fazer um serviço aqui que eu não sei fazer, e é muito pesado. Aí falou o que que era. Aí a mulher falou assim: eu sou sua fada, tudo que cê precisar eu vou te ajudar. Vai ter um jeito de te ajudar. Aí ela viu uma vaquinha na beira da estrada, a vaca pastando, aí a vaca conversou com ela: que que cê lavai fazer com essa trouxa de roupa? Ah, eu vou lavar essa roupa, mas eu não vou dar conta de lavar e minha madrasta vai me bater demais e judiar de mim. Aí ela falou assim: não, boba, cê pode dormir um soninho aí que eu vou dar um jeito nela pr'ocê. A vaca engoliu a roupa e voltou a roupa passadinha. Ela pegou a roupa passada e levou. Quando chegou lá a madrasta ficou boba de ver, né, aí falou assim: Cê vai ver, eu vou inventar um negócio que cê não vai dar conta não. Aí pôs um balde grande lá e aí falou assim: ó, cê vai encher esse balde de água dos olhos dos passarinhos, de lágrima de passarinho, pra mim. Aí ela falou assim: agora que eu não vou conseguir mesmo. Aí ela vai me matar de bater. Mas aí na estrada ela encontrou a velhinha: Ah, minha filha, que que cê tá querendo hoje? Não, eu tenho que encher esse balde com lágrima de passarinho. Ah, mas cê vai dar conta! Eu vou te dar esse assobio aqui pequenininho, cê vai andando lá pro meio da mata, quando cê chegar lá no meio da mata cê põe o balde lá e pode dormir um sono. Aí ela foi, no meio da mata ela deu o assobio, aí ela dormiu um soninho. E os passarinhos vinham e cada um deixou uma gotinha, quando ela acordou de tarde o balde tava quase cheio. Aí ela levou. Quando ela chegou lá a madrasta ficou boba de ver! Mas que que essa menina tá arrumando? !Agora cê vai encher esse colchão de pena de passarinho. Aí foi de novo, ela encontrou a velhinha: agora cê vai fazer a mesma coisa, minha filha. Chegar lá cê vai por lá o colchão estendido e vai dormir um soninho num lençol do lado. Assobia, a mesma coisa. Os passarinhos vinham e deixavam, só saiam com as peninhas da asa e do rabo pra voar e deixavam as penugens tudo lá. Aí de tarde ela veio e falou com a madrasta: ó, a senhora manda os empregado lá buscar porque o colchão eu num aguento trazer não. Aí foi lá, buscou o colchão e trouxe, ela viu que era pena de passarinho mesmo, mais aquelas penugens fininhas. Aí, quando foi no outro dia, ela falou assim: ela vai ver, agora ela vai fazer perto de mim. Aí ela arranjou um pilão bem grande lá que ela tinha e foi e botou uma cuia debaixo, no fundo do pilão, e pôs arroz por cima: agora cê soca esse arroz pra mim, e falou quantos minutos lá, aí ela pegou a mão-de-pilão, ela chorou: agora eu não vou ter ajuda. Quando ela bateu a mão-de-pilão a primeira vez aí quebrou, fez aquela zoeira. A cuia quebrou. E a madrasta deu um coro nela: ah, quebrou minha cuia de estimação! Ela danou chorar: pode deixar que eu vou dar um jeito. Cê dá um jeito nessa cuia e não deixa nem uma marquinha nela, de emendado. Cê não pode deixar nem uma marquinha nela de emendado, heim! Aí ela saiu chorando, mas ela pensou: a fada vai dar um jeito. Chegou na estrada encontrou a fada: ô minha filha... Aí ela contou a história. Oh, cê vai fazer o seguinte, e ela tava com os pedaços de cuia dentro da sacola, tem um gigante que conserta cuia, mas ele mora muito longe, cê quer ir lá? Quero. Eu quero mostrar pra minha madrasta que eu faço as coisas. Aí ela mostrou uma 
ramagem assim no meio da estrada, ela levantou a ramagem assim e falou: cê tá vendo essa porteirinha aqui? É aqui que cê vai passar, mas cê só vai fazer coisa boa aí porque senão cê não consegue não. Aí ela entrou, mas a porteirinha tava assim meio aberta, entreaberta, né, ela falou assim: como é que eu vou passar aqui? Aí a porteirinha falou assim: ô minha filha, me empurra pro cantinho, todo mundo que passa por aqui me bate e eu sinto muita dor. Nesse reino aqui todo mundo fala, todo mundo é muito sensível, precisa de ajuda. Aí ela foi com jeitinho e colocou a porteira lá no cantinho.

Dorvalina, minha irmã, cinquenta anos, me traz de volta uma linda e triste história que eu lembrava apenas pela emoção de ouvi-la, mas não mais o seu enredo. Na sequência da história, Mariazinha, ao passar pela porteira falante, cumpre todas as tarefas de sua longa jornada sempre atenta ao que lhe dissera a fada. Fora dito que ali era o reino onde a boa ação importava mais do que a força, e assim tudo ia se resolvendo.

A nossa memória falha, mas o que nos sobrou, além de algumas histórias e pedaços de outras, são os afagos na alma, a graça das peripécias de muitos personagens, a irreverência de outros.

Outra história de que Dorvalina se lembra, e me emociona poder ouvi-la novamente, é a do Tatu que, desencantado pela princesa e retomando sua aparência verdadeira, a de um lindo príncipe, precisava rapidamente voltar ao seu reino que ficava num lugar muito distante. Muito triste, ela recebe autorização de seu pai para ir atrás do príncipe, mas para chegar tão longe precisará gastar três sapatinhos de ferro, lhe avisa o conselheiro. E ela então inicia sua grande viagem passando primeiro pela casa do sol, depois pela casa da lua e por último a do vento, que dão a ela lindos presentes e a ajudam a encontrar o reino onde vive seu amado.

Lembrar essas histórias é voltar no tempo, e me dar conta de que elas me ensinaram, entre outras coisas, a inventar cenários, pensar em música e sonhar. Ensinaram, sobretudo, a imaginar. Já de cabelos brancos, calos na mão, Tio Geraldo narrava. Narrava meu futuro sem saber, nem sequer suspeitar.

Eram histórias de fadas, bruxas, assombrações, monstros, reis e rainhas, príncipes e princesas, animais falantes, árvores falantes... Lembro-me do encanto e do espanto com as repetidas contações da mesma história. Nelas cabia tudo, inclusive a dor, o medo, aquilo que não me agradava. Havia muitas atrocidades. Lembro, ainda hoje, de meu tio contando a história de Zezinho e Maria. Maria era uma princesa que se apaixonava pelo filho do sapateiro, e numa determinada cena 
os conselheiros do Rei recomendam, para dar cabo do moço apaixonado, formas cuéis que me chocavam muito: jogá-lo num caldeirão de óleo fervente, amarrá-lo com uma corda a um burro bravo e soltar o animal pelas ruas do reino até que o moço morresse, e outras que iam se alternando a cada vez que eram contadas. Enforcamento, trabalhos forçados, guilhotinas, missões impossíveis para crianças criadas por madrastas, como encher um balde com lágrima de passarinho, consertar uma cuia quebrada sem deixar marcas dos remendos, vigiar uma figueira por dias e noites sem poder descansar ou comer um figo sequer, cenas comuns e até aplaudidas no nosso ingênuo, árduo e lúdico mundo da imaginação. Nosso aprendizado do mundo. Mas na cena final Zezinho salvava a princesa da morte, e esse era meu momento de alívio, de redenção.

$\mathrm{Na}$ história de Zezinho e Maria, depois de muito conversar com seus conselheiros de reinos distantes, o pai de Maria decide, aconselhado por um dos sábios consultados, dar um navio sem acabamentos para cada um dos três pretendentes da princesa e mandá-los ao mar, o que voltasse mais rico se casaria com sua filha. Como me aliviava essa possibilidade de justiça, de concretização daquele amor tão bonito! Zezinho é o que mais demora a voltar, mas é o que volta rico vencendo a tarefa dada pelo Rei. Três dias de festa, banquetes, vestidos bordados a ouro com laços de fita, entre outras delicadezas próprias dessas histórias do tempo do era uma vez num reino distante... E duas frases são cruciais nessa história, a primeira é quando Maria, logo depois de se casar com Zezinho, tendo ele cumprido a tarefa dada pelo pai de sua amada, diz, pensando alto: é, como é que pode a filha do rei casar com o filho do sapateiro... Zezinho ouve e toma essas palavras de Maria como ofensa, e essas palavras causam o desespero de Maria e a separação dos dois, e Zezinho vai embora. Outra frase é dita por Zezinho e fecha a história: pois é, como é que pode o filho do sapateiro salvar a princesa da morte. Essa era minha "vingança", a minha "vitória". Hoje percebo claramente as marcas deixadas em mim pelo mundo lúdico e atroz dos contos que me contavam. O contador de histórias Francisco Gregório, conta um episódio de sua vida em que reconhece o seu aprendizado emocional com a história da D. Baratinha.

Tempos depois, meu avô morreu. Minha mãe e minhas tias prepararam os netos para o velório. Fomos todos. Meu avô no caixão, em cima da mesa. Os netos em volta. Meu avô, solene, sereno, de olhos fechados. Eu olhava meu avô, ali, de olhos 
trancados, olhava... De repente, senti um aperto no coração, uma dor no peito e chorei... chorei... chorei. Chorando eu tive um deslumbramento, uma descoberta: estava com dor de Baratinha. Tomava ciência, pela primeira vez, da dor da perda. Sim, estava com dor de Baratinha! (GREGÓRIO, 2000. p. 15)

Nesse tempo do era uma vez, a truculência, a punição, o castigo, assim como a beleza e ingenuidade das princesas e moças pudicas, faziam parte de um mundo onde eu ia e podia voltar. Experimentava as emoções que a imaginação me permitia e retornava sã e salva para a minha realidade. Terezinha, cinquenta anos, também lembra de alguns fragmentos de histórias, e conta de sua emoção ao ouvilas, sua crença no mundo dos contos que que ouvia.

Terezinha: ué, quem contava história pra mim era o Carmo Félix, e convidava as crianças, juntava aquele monte de criança e subia lá pra casa da Tia Dina, aí reunia lá de noite, e a gente ficava a noite inteira lá, contano história até de madrugada. Aquelas história que a gente pensava assim: Nossa Senhora, vai acontecer mesmo! É verdade! As histórias de antigamente, Nossa Senhora! parecia que era verdade. Escutava, e quanto mais contava pra gente, mais vontade de ouvir aquela história... Nossa Senhora, eu gostava demais, gente! Aí, no final da história assim, ah, a gente parecia que aquilo era verdade mesmo. A história pra mim era real assim, ó, do jeito que eles contavam. Pra mim... era bom demais! Era bom a gente ouvir, a gente acreditava mesmo. Coisa de criança, né? A gente era criança.

Bruno Bettelheim ${ }^{1}$, em A psicanálise dos contos de fadas, chama a atenção para a função terapêutica dos contos de fadas.

Como educador e terapeuta de crianças gravemente perturbadas, minha tarefa principal foi a de restituir um significado às suas vidas. (...) Vi-me confrontado com o respeito a essa tarefa, nada é mais importante do que o impacto dos pais e das pessoas que cuidam da criança, em segundo lugar vem nossa herança cultural, quando transmitida à criança de maneira correta. Quando as crianças são pequenas, é a literatura que canaliza melhor essa informação. (BETTELHEIM, 1997, pg. 10)

Explicações, conselhos tentando fazer com que a criança compreenda racionalmente as situações conflituosas pelas quais possam estar passando não dão conta do problema, pois a criança não é capaz de se colocar no lugar do adulto e elaborar pela razão, mas o conto de fadas lhe mostra como pode viver com seus

1

Durante a Segunda Guerra Mundial foi deportado pelos nazistas para o campo de concentração de Dachau e, mais tarde, para Buchenwald. Aí pôde observar os comportamentos humanos quando o indivíduo é sujeito a condições extremas, percepcionadas como radicalmente destrutivas (desumanização), que estiveram mais tarde na base das suas teorias sobre a origem do autismo. Graças a uma anistia em 1939, Bettelheim e centenas de outros prisioneiros foram libertados, o que lhe salvou a vida. Emigrou então rumo aos Estados Unidos, onde foi professor de psicologia em universidades americanas e dirigiu o Instituto Sonia-Shankman em Chicago para crianças psicóticas, destacando-se o seu trabalho com crianças autistas. Cometeu suicídio em 1990. 
próprios conflitos, sugere fantasias que ela nunca poderia inventar por conta própria. (BETTELHEIM, 1997, p. 159).

Sexualidade, conflitos edipianos, angústia, raiva, morte, vida, medos, desejos repreensíveis, a transformação do próprio corpo, são tratados nos contos de fada sob a roupagem da fantasia e a criança pode assim experimentar sentimentos como a raiva, o poder de matar ou de aprovar tal atitude, colocar-se no lugar do herói ou do vilão sem com isso ser repreendida, e assim vai ganhando maturidade. Quando a criança entra em contato com a realidade da condição humana através das histórias, e toca o lado instintivo do bicho homem, o jeito às vezes perverso que cada um tem de defender o próprio território afetivo; esse vaie-vem do mundo real ao mundo da fantasia e vice-versa vai ajudando essa criança a entender o ser humano. Com a educação, o aprendizado dos costumes, da cultura na qual está inserida, vai aprendendo a dominar os instintos, a ser humano para além de sua natureza. É na cultura que nos tornamos sociáveis, assim nos percebemos como seres afetivos, com capacidade de compreender a condição do outro, e nos tornamos parte de uma sociedade, de uma família e nos apaziguamos com nós mesmos.

O imaginário dá à criança o poder de reflexão, de tomar partido, de explicitar desejos através do simbólico. De um modo geral, Bettelheim abre nossos olhos para a profundidade e a potência criadora do ser humano na infância e o quanto pode ser compensador ou desastroso o modo como as informações chegam até ela.

Desde a antiguidade que nós humanos temos o hábito de contar e de ouvir histórias. Inicialmente as histórias tradicionais eram contadas para o público adulto, e quando começaram a ser recolhidas e coligidas em livros estes também eram escritos para adultos. O mundo do adulto e da criança era um só, a noção de infância ainda não havia sido forjada, não havia preocupação com a atenção especial à infância e não eram conhecidas todas as suas complexidades. É historicamente recente a noção de infância, a dedicação de autores e teóricos para com o tema.

Que criança esqueceria o batizado da sua boneca quando ela mesma, junto com primos, construiu a própria casinha feita com bambu e folhas de bananeira, com direito a fogãozinho a lenha onde preparou arroz, tutu e frango frito, ainda que ficasse tudo com gosto de fumaça; e que o pai, imitando os batizados de 
verdade, soltou fogos para festejar quando os padrinhos chegaram com a boneca já batizada? Inventávamos nosso mundo. Esse mundo em que era possível provar, no sentido de quem prova uma comida ao prepará-la, da realidade pelo lúdico e nos aproximava, a mim e os de minha geração, do mundo dos adultos, mas ao mesmo tempo nos preservava o mundo da inocência. Tendo vivido muito de perto experiências como beber água de mina na concha da mão ou na folha do inhame, tomar banho de rio enquanto minhas irmãs mais velhas lavavam roupa, ter como limitador de minhas ações o cuidado dos pais e de toda uma comunidade e não o medo da violência, me ajudou a ler o mundo com outros olhos; e faz do meu percurso entre o Córrego dos Januários e o Rio de Janeiro, mais especificamente a PUC-Rio como aluna de Letras, um laboratório para pensar a minha formação cultural. Por essas e outras, percebo mais concretamente a grandeza das transformações culturais e sociais pelas quais passei, para o bem e para o mal, seus prós e contras.

Falo desde essa terra que inaugurou a luz dos meus olhos porque vivi ali momentos, culturalmente falando, muito ricos, que me formaram como apreciadora de histórias orais e me abriram portas para o prazer da leitura. Essas histórias foram sendo esquecidas por não serem mais contadas. Ao descobrir já na década de 1990, o livro Histórias da Baratinha (Ed. Livraria Quaresma), de Figueiredo Pimentel, e Lendas e fábulas do Brasil, seleção de histórias organizadas por Ruth Guimarães, (Edições Círculo do Livro) acabei encontrando escritas muitas das histórias que eu ouvia quando menina, dentre elas A Pombinha e a Moura-Torta, Os dois papudos, Os passarinhos da figueira, Arte de BrancaFlor, Pedro Malazartes e O Príncipe Papagaio. Trabalhando como babá no bairro do Leblon-RJ, lia para preparar o sono de Natalie o livro que pertencera ao seu pai, e recuperava histórias de minha própria infância. Eu nunca havia pensado que as histórias que eu ouvira poderiam um dia ter figurado ou vir a figurar nos livros. Era a literatura a que eu tivera acesso pela voz do meu tio Geraldo, homem de mãos calejadas e de doçura na voz, que ficou marcado para mim e meus primos que sentávamos à volta dele aquecidos pelo fogo da fornalha no centro da cozinha de chão de terra Até onde eu me lembro, ele não sabia ler, nem tinha livros.

Contar histórias é uma prática ancestral, contudo depende do preparo e da habilidade de quem conta. Sentado em praças orientais sobre seus tapetes, ou nas tribos de tradições orais, os contadores vão burilando seu ofício como o poeta faz 
com seus versos. Contam e recontam, procurando as nuances, as suspensões, as imagens, as situações surpreendentes, inusitadas que prendam o ouvinte. A vida moderna tem deixado ao espaço familiar pouca oportunidade de trocas verbais que não sejam as mais ordinárias, em meio a ordens, gritos, recriminações: nenhum tempo é destinado para a escuta e a pronúncia - as crianças andam com fome de ouvir e sede de falar.

De uma boa história ninguém escapa, sempre queremos ouvir mais uma, como o sultão Chahriar que, adiando a morte anunciada, redescobriu o prazer na vida, usufruindo durante o dia das histórias que Cheherazade lhe narrava, à noite.

Cheherazade a essa altura percebendo que já era dia, e sabendo que o sultão costumava levantar-se de manhã bem cedo para fazer sua prece e reunir o conselho, deixou de falar.

- Por Deus, minha irmã, é maravilhosa tua história - disse Dinarzade.

- A continuação é mais surpreendente ainda - respondeu Cheherazade - e tu concordarias se o sultão me deixasse viver ainda hoje e me permitisse contá-la na próxima noite. Chahriar, que ouvira Cheherazade com prazer, pensou consigo mesmo:

- Esperarei até amanhã, e ela morrerá mal eu tenha ouvido o resto da história.

Resolvido, portanto, a não matar Cheherazade naquele dia, levantou-se para fazer sua prece e ir ao conselho.

Além de tudo o que já dissemos, está a riqueza extraordinária de ir povoando a memória, insistindo em sentimentos, emoções, afetos e também ideias, comparações, traços que se vão criando para novas associações, à medida que cresce a capacidade discursiva. (...) O que lembramos, seletivamente, lembra quem somos, quem "estamos sendo", ao nos constituir como seres de histórias. (YUNES, 2009. p. 18-19)

Neste meu lugar de nascimento e de contato com uma cultura rara hoje em dia como prática interiorana - e que foi se trasladando das encruzilhadas, das beiradas das fogueiras para palcos, salas de leitura, e outros espaços de formação de leitores, mesmo lá no interior - o imaginário era o tempo todo estimulado. Os contadores eram meu livro ambulante. Minha vontade de ser escritora nasceu da minha prática de ouvir histórias e por perceber que a minha pequena comunidade, hoje com cerca de 300 habitantes, a grande maioria parentes, tinha também histórias para eu contar. Uma das histórias que mais me encantava quando criança a que já me referi, eu encontrei há poucos dias, na internet, na forma de cordel, mas a história das minhas lembranças era totalmente outra do meio para o fim. Do quem conta um conto aumenta um ponto, a história de Zezinho e Maria chegou a mim com remendos que, a meu ver, a deixaram muito mais bonita e marcante. $\mathrm{E}$ na conversa com Zilmar, 77 anos, moradora do Córrego dos Januários, ela me surpreende lembrando a mesma história. Conta que seu pai gostava de tocar sanfona, e pedia para ela e as irmãs cantarem enquanto ele tocava. E Zilmar se orgulha de tê-la na memória ainda hoje, e vai rememorando alguns dos versos que 
coincidem com o texto que descobri recentemente, da lavra do paraibano Silvino

Pirauá de Lima.

Zilmar: eu sabia a história do Zezinho e Mariquinha, cê já viu contar ela? Eu comecei contá ela pr'ocê um dia aqui mas nós num cabô de contá. Eu agora já tropico muncado, eu num falo direito mais não, porque o papai, ele tocava era na sanfona, eu aprendi contar essa história foi com ele, que ele cantava. De primeiro eu sabia até a toada, mas agora eu perdi a toada. Mas ele cantava, porque a história do Zezinho é muito comprida.

Toquinha: A que eu conheço é muito comprida.

Zilmar: como é que é a que ocê sabe?

Toquinha: conta a senhora primeiro. (risos)

E Zilmar então conta...

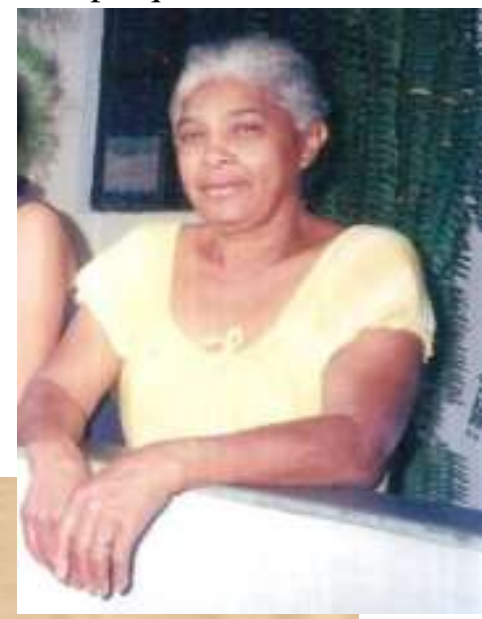

História de Zezinho e Mariquinha (Versos lembrados por Zilmar)

Havia numa cidade um home de grande riqueza bem perto dele morava um pobre por natureza tanto tinha um de rico como o outro de pobreza O rico, pobre coitado só tinha uma filhinha como era filha única no palácio era rainha chamava ela Maria tratava de Mariquinha O pobre, homem coitado por viver bem probrezinho além de ter muito filho tinha um bem pequenino Ele chamava José e tratava de Zezinho O pobre, homem coitado por não possuir fazenda vivia de sapateiro trabalhava numa tenda 1. tudo que ele fazia só dava para a merenda

Figura 4: versos lembrados por Zilmar
O ricaço milhonário mandou ensinar Mariquinha E lhe deu uma criada para não andar sozinha pela rua da cidade quando ia e quando vinha. Um dia que Mariquinha passeava na cidade por lá encontrou Zezinho que era da sua idade foramjuntos conversando consagrando amizade perguntou ele quem era respondeu: sou seu vizinho como de fato ele era morador de bem pertinho até aí Mariquinha não conhecia Zezinho Foi andando todos juntos todos três em companhia se Zezinho não fosse em casa Mariqui nha também não ia quando um passava tormenta o outro também sentia (...)

A história vai surgindo nos versos de Zilmar mesmo com os tropeços da lembrança. E nas semelhanças e desencontros dos versos vão ficando evidente os 
muitos caminhos por onde andam as histórias, onde pedaços são perdidos e outros acrescentados.

COLEÇAO LUZEIRO

Silvino Pirauá de Lima

\section{HISTÓRIA DE}

\section{ZEZIMHO E MARIQUINHA}

Direçä̉o de

ARUINDO PINTO DE SOUZA

Textos revistos e classificados por HéLIO CAVENAGHI

Capa

GLEN

Direitos adquiridos e registrados de acordo com a lel na Biblloteca Nacional

1974

LUZEIRO EDITORA LIMITADA

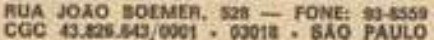

Figura5: História de Zezinho e Mariquinha 1

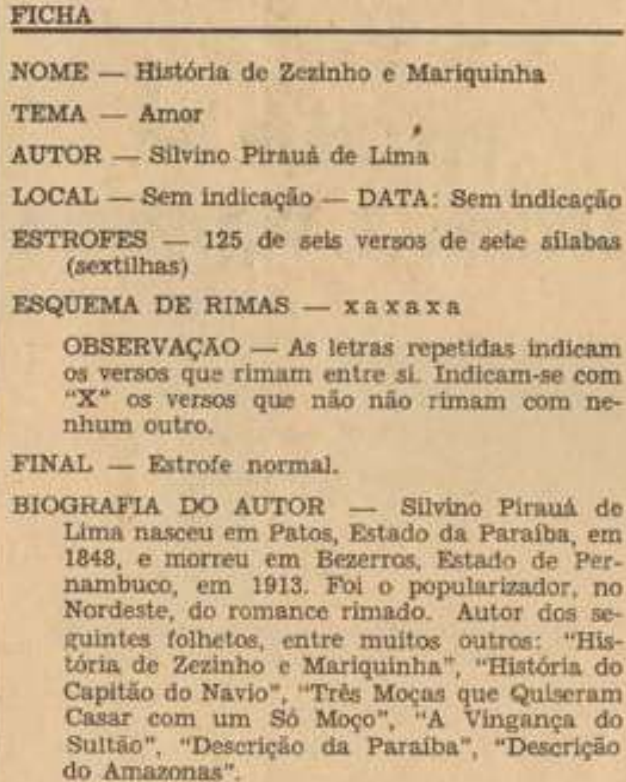

Figura 6: História de Zezinho e Mariquinha 2 


\begin{tabular}{|c|c|}
\hline \multirow{2}{*}{$\begin{array}{c}\text { História de } \\
\text { Zezinho e Mariquinha }\end{array}$} & gRVYNO PIRAUA DE LIMA \\
\hline & $\begin{array}{l}\text { O rico nabo tinha filhos, } \\
\text { apenas uma filhinha, } \\
\text { como era filha unica } \\
\text { do sobrado era rainha, } \\
\text { era chamada Maria, } \\
\text { tratavam por Mariquinha. }\end{array}$ \\
\hline $\begin{array}{l}\text { Vou contar aos bons jeitores } \\
\text { uma historla mui distinta; } \\
\text { quero contar a verdade, } \\
\text { se nâo for quem me desmintat: } \\
\text { no coraciolo do quem ama } \\
\text { uma amizade o que pinta. }\end{array}$ & $\begin{array}{l}\text { Lhe botaram este apelido } \\
\text { por sua delicadeza, } \\
\text { pelo seu porte elegante, } \\
\text { sua graca e singeleza. } \\
\text { Apesar da pouca idade. } \\
\text { era um mimo de beleza. }\end{array}$ \\
\hline $\begin{array}{l}\text { Havis em uma cidade } \\
\text { um homem de muita riqueza, } \\
\text { e perto dele morava } \\
\text { um pobre por natureza - } \\
\text { tanto tinha um de rico, } \\
\text { como o outro tinha de pobreza. }\end{array}$ & $\begin{array}{l}\text { Com oito anos de idade } \\
\text { era rainha das flores, } \\
\text { se comparava ums santa } \\
\text { no meto dos pecadores, } \\
\text { o seu riso recordava } \\
\text { sublimes juras de amores. }\end{array}$ \\
\hline $\begin{array}{l}\text { Esse homem era rico, } \\
\text { senhor de muitos milhōes. } \\
\text { determinava a cidade } \\
\text { em muitas reparttçóes, } \\
\text { afinal satisfazia } \\
\text { todas as suas pałxöes. }\end{array}$ & $\begin{array}{l}\text { O pobre do sapateiro, } \\
\text { com o seu viver pobrezinho, } \\
\text { alem de ter multos filhos } \\
\text { tinha um pequenininho, } \\
\text { que chamavam de José } \\
\text { e tratavam por Zezinho. }\end{array}$ \\
\hline $\begin{array}{l}\text { O pobre do sapateiro } \\
\text { náo possuia riqueza, } \\
\text { vivia de sua arte } \\
\text { no estado de pobreza, } \\
\text { mas o pouco que ganhava } \\
\text { dava prá sua despesa. }\end{array}$ & $\begin{array}{l}\text { Bsse era um bom menino } \\
\text { por obra da Providência, } \\
\text { apesar de ser tāo novo } \\
\text { timha rara intellgéncla, } \\
\text { o seu pal se orgulhava } \\
\text { por ver sua sapiencia. }\end{array}$ \\
\hline
\end{tabular}

Figura 7: História de Zezinho e Mariquinha 3

Figura 8: História de Zezinho e Mariquinha 4

As lembranças de Zilmar são retalhos do mesmo enredo escrito pelo cordelista paraibano, resquícios de memória que vão me mostrando que essa cultura longe dos grandes centros brasileiros onde os livros e as informações do mundo quase não chegavam, tinha e tem raízes na antiguidade e, tendo sido trazidas pelos colonizadores, que se mantêm em regiões distintas, ganham características próprias, resistindo ao tempo. Nas histórias de Zilmar, nos romances, nas festas com seus maracatus, reizados, folias de Reis e de outros santos, tambores de mina, burrinhas e tantas outras manifestaçõesculturais consideradas folclóricas está a marca da tradição. Força impressa na singeleza de povoados na sua lida de plantar e colher quando Deus permite, e de fazer de tudo motivo para festejos. 
O ofício de contador de histórias, para além de divulgar a cultura, recheia nossa memória afetiva, resguarda a pureza de uma experiência que vem sendo encoberta pelo advento da tecnologia, das mídias e suas urgências. O tempo do narrador é mais lento, mais calmo, mais degustado, degustável. Walter Benjamin, pensador alemão, fala dessa experiência do narrador que, segundo ele, entrou em extinção na modernidade.

A experiência que passa de pessoa para pessoa é a fonte a que recorreram todos os narradores. E, entre as narrativas escritas, as melhores são as que menos se distinguem das histórias orais contadas pelos inúmeros contadores anônimos. Entre estes, existem dois grupos, que se interpenetram de múltiplas maneiras. A figura do narrador só se torna plenamente tangível se temos presentes esses dois grupos: "Quem viaja tem muito que contar", diz o povo, e com isso imagina o narrador como alguém que vem de longe. Mas também escutamos com prazer o homem que ganhou honestamente sua vida sem sair do seu país e que conhece suas histórias e tradições. Se quisermos concretizar esses dois grupos através dos seus representantes arcaicos, podemos dizer que um é exemplificado pelo camponês sedentário, e o outro pelo marinheiro comerciante. Na realidade esses dois estilos de vida produzem de certo modo suas respectivas famílias de narradores. (BENJAMIN, 1994, p. 198-199)

Benjamin fala dos tempos de guerra, do silêncio produzido pelo terror vivido nos campos de batalha, e esse narrador que tem apenas o seu próprio corpo indo e vindo como propagador das notícias, das histórias de viagens, que não contava com tecnologias avançadas para contar os acontecidos passava a não ter vontade de contar. Isso é um fato. As condições afetivas desses momentos de transmissão, de compartilhamento de experiências tornam-se raras.

No Córrego dos Januários, era possível experimentar esse modo de narrar tradicional até bem pouco tempo. A ausência dos meios de comunicação nos colocava neste espaço comunitário onde as experiências eram necessariamente transmitidas no dia-a-dia. Penso nas discrepâncias quanto ao desenvolvimento em todas as regiões do Brasil em que metrópoles totalmente cosmopolitas parecem pertencer a um outro país que não o que ainda hoje mantém comunidades isoladas dos avanços tecnológicos, econômicos e culturais. E em pleno 2013, muitas comunidades no Brasil e pelo mundo afora vivem, pelo distanciamento geográfico, pelo esquecimento histórico ou por opção, longe dos modernismos, e resguardam suas expressões genuínas de culturas consideradas tradicionais. Eu pude experimentar a drástica e a rápida transformação cultural daquele meu lugar. Em trinta anos passamos, como comunidade, por um nível de desenvolvimento 
significativo, e é preciso aprender a lidar com tantas mudanças sem muitas angústias, pois, diferente das cidades que foram se desenvolvendo juntamente com os avanços tecnológicos e industriais,o Córrego dos Januários, de um dia para outro, entrou na era tecnológica, com a chegada da energia elétrica, em 1984.

Ter vivido nessa comunidade que experimentou a precariedade, a falta de energia elétrica, e que por isso não tinha acesso a informação e bens de consumo como televisão, geladeira, aparelhos de som, computadores, me permitia estar em contato com uma realidade muito distante da modernidade. Mas, acompanhando o desenvolvimento tecnológico que acelerou mundo afora, hoje por lá as roças estão salpicadas de antenas de sinal de celular, parabólicas e internet que despontam no meio das lavouras e nos quintais das casas como um produto e evidência do progresso. O tempo acelerou também lá pelos interiores de Minas, e no correcorre diário esse narrador que desperta o imaginário de quem o escuta, vai ficando escondido, mas pulsa.

Vivemos níveis distintos e voláteis de modernidade. No meu diálogo com Benjamin há uma espécie de vai-e-vem, de é e não é. As afirmações de Benjamin, sobre o empobrecimento da experiência na modernidade, me incomodam, por acreditar que não somos, a comunidade de Córrego dos Januários e outras Brasil afora com as mesmas características, pobres em experiência, vivemos transformações radicais em curtos espaços de tempo e precisamos, isto sim, estar sempre alertas para não nos perdermos na aceleração comum dos nossos dias, pois corremos o risco do soterramento da história que nos pertence, da sobreposição do novo sobre o que construímos como grupo cultural e social durante muitos anos. Suas observações a respeito do declínio da narrativa tem, a meu ver, raízes fortes e profundas no contexto em que vive e que tem consequências em todo o mundo como regra geral, mas as transformações não são homogêneas, e muitos grupos sociais convivem com o novo, mas as novidades são assimiladas mais lentamente, num tempo próprio permitindo manter viva a essência o que os caracteriza como grupo.

Se a arte da narrativa é hoje rara, a difusão da informação é decisivamente responsável por esse declínio.

Cada manhã recebemos notícias de todo o mundo. E, no entanto, somos pobres em histórias surpreendentes. A razão é que os fatos já nos chegam acompanhados de explicações. Em outras palavras: quase nada do que acontece está a serviço da 
narrativa, e quase tudo está a serviço da informação. Metade da arte narrativa está em evitar explicações. (BENJAMIN, 1994, p. 203)

De fato, a informação em tempo real e em maior volume predomina sobre o modo de narrar no momento em que o filósofo reflete e escreve acerca do tema e ainda muito mais nos dias de hoje, mas, nas minhas idas e vindas apoiada nas reflexões de Benjamin e, por outro lado, contrapondo, muitas comunidades guardam modos de vida e de convivência onde a "pulsão narrativa" é evidente. Num momento crítico da história da comunidade do Córrego dos Januários em que eu faço o "apelo de memória" que é ouvido por Denise Gusmão (ver capítulo 3), tivemos a chance de parar e pensar sobre o que nos estava acontecendo, e então foi possível perceber a chama acesa da nossa cara condição de comunidade, de reconhecimento de valores que pareciam estar se perdendo e o reconhecimento de que o narrador ainda estava e está presente. As condições de narrativa estavam vivas aguardando quem delas quisesse desfrutar, mas é necessário trabalhar para torná-las vivas. São momentos de ressignificação do ato de narrar, de reconhecimento das transformações pelas quais passamos e de percepção de que não devemos acompanhar cegamente o desenvolvimento acelerado desse início de terceiro milênio.

Benjamin está se colocando num momento de crise da narrativa, do surgimento do romance pelo fator distanciamento, de isolamento que empobrece a narrativa, e sua percepção naquele momento histórico, penso, é também um pedido de atenção, de cuidado com as transformações tão bruscas em meio a tanta brutalidade. E hoje, pensar em perdas e/ou ganhos, ou, que o moderno supera o tradicional, e vice-versa,no contexto das experiências vividas no Córrego dos Januários, me parece pouco eficiente; não traduz a nossa condição cultural, nosso modo de vida. Mantemos, com a convivência comunitária, espaços onde a narrativa brota, onde a essência do narrador está viva; e desfrutamos do moderno, do mundo globalizado. São outros tempos. Benjamin não privilegia este ou aquele modo de narrar, mas sim, explicita a transformação, acende a luz que adverte para o perigo da perda deste elo tão importante entre gerações, a transmissão do conhecimento através do ato de narrar. Compreendo que a narrativa tradicional como regra foi ultrapassada com a modernidade, mas a narração está aí, a narrativa é necessária e possível atendendo aos modelos do século XXI; enquanto 
também os narradores à moda antiga, as Zilmares e os Genorinhos que contam a seu modo e gosto suas experiências de vida, as histórias que aprenderam "de ouvido" ou nos raros livros que tiveram vida afora, são a resistência do que nos é essencial, penso. E fica uma pergunta: nós, quando mais velhos, não teremos histórias, experiências, para compartilhar? Do nosso tempo acelerado, não nos ficará nada? O "Dicionário eletrônico Houaiss da língua portuguesa 3.0” define, na rubrica filosofia, a experiência como qualquer conhecimento obtido por meio dos sentidos e forma de conhecimento abrangente, não organizado, ou de sabedoria, adquirida de maneira espontânea durante a vida; prática; se pensamos que nos nossos dias a experiência está de fato empobrecida, seria, segundo o Houaiss, pensarmos que não aprendemos através dos nossos sentidos, que não temos conhecimento e sabedoria adquiridas na prática diária de sermos homens nesses tempos conturbados.

Tudo está em extinção há milênios, somos perecíveis assim como o que produzimos como fazedores de cultura. Ninguém quer ficar "parado no tempo", queremos superar o que vem antes de nós, somos e continuaremos sendo superáveis como modelo de homem e de cultura. Se rareiam os narradores marinheiros e os camponeses sedentários, não seria plausível considerarmos outros modos de narrar sem que isso signifique pobreza de experiência? Outras sensações, outras memórias merecemserresguardadas. Mesmo as nossas narrativas entrecortadas pela ligeireza do tempo nos tempos de agora, creio, nos comunicam muito. Quando Benjamin levanta a questão da nossa pressa aniquiladora das experiências, está também, na minha maneira de ver e de pensar, deixando uma pista de que refletir sobre essa nossa crônica falta de tempo pode, e talvez deva, nos ajudar a reconhecer, buscar e/ou criar espaços onde possam brotar os Leskovs ${ }^{2}$ modernos. Que nos mantenham atentos ao que historicamente nos constitui. É possível? São perguntas que vêm junto com a compreensão de que Benjamin trabalha sobre bases muito claras para suas ideias acerca dos tempos de guerra,

\footnotetext{
${ }^{2}$ Nikolai Leskov nasceu em 1831 na província de Orjol e morreu em 1895, em S. Petersburgo. Por seus 'interesses e simpatias pelos camponeses, tem certas afinidades com Tolstoi, e por sua orientação religiosa, com Dostoievski. Mas os textos menos duradouros de sua obra são exatamente aqueles em que tais tendências assumem uma expressão dogmática e doutrinária - os primeiros romances. A significação de Leskov está em suas narrativas, que pertencem a uma fase posterior. Desde o fim da guerra houve várias tentativas de difundir essas narrativas nos países de língua alemã. Além das pequenas coletâneas publicadas pelas editoras Musarion e Georg Müller, devemos mencionar, com especial destaque, a seleção em nove volumes da editora C. H; Beck. (BENJAMIN, 1994, p. 197)
} 
das atrocidades vividas no seu tempo, que desestimulam a narrativa, mas ela, continuo "sentipensando", , resiste.

Por mais familiar que seja seu nome, o narrador não está de fato presente entre nós, em sua atualidade viva. Ele é algo de distante, e que se distancia ainda mais. Descrever um Leskov* como narrador não significa trazê-lo mais perto de nós, e sim, pelo contrário, aumentar a distância que nos separa dele. Vistos de uma certa distância, os traços grandes e simples que caracterizam o narrador se destacam nele. Ou melhor, esses traços aparecem, como um rosto humano ou um corpo de animal aparecem num rochedo, para um observador localizado numa distância apropriada e num ângulo favorável. Uma experiência quase cotidiana nos impõe a exigência dessa distância e desse ângulo de observação. É a experiência de que a arte de narrar está em vias de extinção. São cada vez mais raras as pessoas que sabem narrar devidamente. Quando se pede num grupo que alguém narre alguma coisa, o embaraço se generaliza. É como se estivéssemos privados de uma faculdade que nos parecia segura e inalienável: a faculdade de intercambiar experiências. (BENJAMIN, 1994, p. 197)

Considero-me uma narradora dos tempos modernos. As experiências que tive na infância me inspiram, mas sei das limitações do meu tempo. Sei que o chão onde piso desde que nasci está repleto de ensinamentos, alimento para o meu fazer criativo e narrativo num momento em que as distâncias se desfazem atendendo à pressa de agora, distâncias estas que se agigantam no que toca os afetos que também são propiciados nos momentos de intercâmbio de histórias, ainda que breves, propiciadas pelos aparatos tecnológicos.

Durante anos de trabalho de busca por quem se lembre das histórias que me restam em pedaços que não consigo recuperar de memória, nada havia encontrado, o que me fazia pensar que esse narrador à moda antiga, de fato, não estava mais à disposição, e como muito se diz, vinha se tornando peça de arquivo, sujeito reverenciado pelo que foi. Mas ao longo da pesquisa alguns relatos me levam por outros caminhos. Agenor Caetano da Silva, o Seu Genorinho, como é mais conhecido, fala da tristeza de já não ter mais sua grande plateia, se ressente

\footnotetext{
${ }^{3}$ Sentipensar, termo criado pelo prof. S. de la Torre (1997), em suas aulas de criatividade na Universidade de Barcelona (Torre, 2001), indica "o processo mediante o qual colocamos para trabalhar conjuntamente o pensamento e osentimento (...), é a fusão de duas formas de interpretar a realidade, a partir da reflexão e do impacto emocional, até convergir num mesmo ato de conhecimento a ação de sentir e pensar" ( Torre, 2001:01).

Para o prof. S. de la Torre, este termo traduz um processo de fusão e de integração do "sentirpensar", associado a outros impulsos básicos como persistir, interagir, atuar, comunicar, etc. Para ele, são duas categorias complementares, duas polaridades, uma envolvendo o âmbito afetivoemocional e a outra o âmbito cognitivo. Daí a necessidade, segundo De la Torre (ibid.) de uma concepção holística e integradora da realidade, onde o biológico, o psicológico e o sócio-cultural representam dimensões parciais de uma realidade complexa. (MORAES; TORRE, p. 3)
} 
de que muitos já não tenham paciência para suas longas histórias, mas reconhece que quando conta, emociona.

Seu Genorinho: (...) A gente lembra, a gente tem saudade. A gente morava tudo junto assim. À noite assim, no tempo de frio tinha sempre um fogo assim na cozinha, na beira do fogão. Sentava ali, Maria costumava fazer uns bolinhos pra nós, uma broa, e aí eu contava história pra eles. Contava muita história. Mesmo fora assim, eles me chamavam pra contar. Mas depois foi acabando tudo, a televisão foi montando em cima. (...) Fica tudo entretido com a televisão, essa bobajada e num pede. Se o sujeito pedir: vai lá contar uma história; é pra prestar atenção, né? Prestar atenção naquilo, botar sentido. Mas a gente contar uma história, outro tá contando um caso ali, num tá prestando atenção. (...) Tem muitos menino assim que nem sabe que que é história. Essa meninada de hoje, nova, né? Tem muitos que até vê falar mais não sabe. Outro dia eu fui no Colégio aqui contar história. Aí eu fui contar uma história pra eles lá que a moça pediu pra ir contar, uma história pra aquelas formandas fazer ali um negócio duma redação que elas iam fazer lá, e precisava dum sujeito contar assim uma história, uns negócio do passado mais assim pra elas poder fazer aquela redação. Então eu fui lá e contei pra elas essa história do Lampião lá, aí elas ficaram emocionadas com o negócio. (GUSMÃO, 2004, p. 27)

Seu Genorinho, falecido recentemente, me relatava, alguns anos atrás, que na meninice tinha o hábito de reunir amigos em volta de pequenas fogueiras nas encruzilhadas dos caminhos entre casas de lavradores e suas roças, e contar causos, histórias que ora reproduziam o que ouvira de outros contadores, ora recitar versos, hábito este que durou toda uma vida. E num outro trecho da conversa o que surge é o velho narrador, o contador de causos que gosta muito de uma boa prosa.

Toquinha: Qual é a profissão do senhor?

Seu Genorinho: Lavrador. Sou casado e tenho dez filhos. Tenho esposa e dez filhos.

Toquinha: O senhor tem netos?

Seu Genorinho: Tenho. Dezoito netos e três bisnetos.

Toquinha: E o senhor costuma contar histórias pros seus netos?

Seu Genorinho: Costumo. Porque, acostuma quando eles tá todo mundo junto aqui a gente costuma contar alguma história pra eles, né?

Toquinha: E eles se interessam em ouvir história?

Seu Genorinho: Os meus netos gostam muito. Assim, eles vem aqui, a gente conta história pra eles e eles gostam muito de ouvir. As meninas, os meninos mesmo depois de crescido, que mora em Belo Horizonte, eles tudo gosta de história. Sempre quando eles vem aí a gente conta história. Inclusive eu fui lá em Belo Horizonte passear na casa da minha menina lá, até contei pro Dom Morais. A Maria Lúcia falou com ele: Ah, papai é contador de história. Uma dó que ele não pode ficar aí, Dom Morais, pra contar uma história."

O Dom Morais, vai ele é muito popular, aí daí a pouco chegou ele e um outro padre, que trabalha com ele na igreja. Ele chegou e tal e: ah Agenor, vim aqui pr'ocê contar uma história pra mim. Aí ele falô: conta uma história pra nóis aí. Diz que ocê conta uma história muito bonita aí do Lampião da Morte. Cumé 
que ocê conta? Ah, eu conto a história do Lampião da Morte, mas a gente passa muito tempo assim, porque lá no interior lá eles gostavam muito de história mas agora com esse negócio de televisão o pessoal, os menino que gosta de história é criança, né? Quer dizer, eles chama agente pra contá uma história na casa deles começa ouvi direitinho daí a pouco chega a hora da novela eles vão saino, vão saino, largano, fica um, dois só e fica sem graça. Mas então a gente vai largano de contá, né? De maneras que eu contei pra ele uma história do Lampião. Ele ficou muito entusiasmado. "ô Agenor, como é que pode, que ocê tem uma memória assim!" Falei: quando eu era sortero, que era mais forgado, trabalhava muito, mas trabalhava com tropa, jogava muito futebol, essa coisa, e era mais forgado. Eu pegava um livro de história assim ó, pegava ele e lia umas duas, três vez assim.

Toquinha: O senhor tinha livros de história?

Seu Genorinho: Eu tinha livro de história. Eu pegava aqueles livro assim. As vez na hora que eu tava forgado assim eu pegava e ficava leno e rimava aquilo tudo, boba.

Toquinha: É mesmo Seu Agenor?

Seu Genorinho: Eu rimava aquilo tudo. Mas depois a gente foi cresceno, o serviço foi apertano. A gente foi largano, o negócio foi apertano. (risos) A gente largou aquilo pra lá, então eu contava pra ele uma história do Antônio Sirvino, que era um valente. Antônio Sirvino era um valente lá de Pernambuco. Então ele brigava muito. E juntou aquela turma e tal e começô a brigá. Primeiro aconteceu que eles mataro o pai dele, né? Então foi que ele disse:

\author{
Eu nasci em setenta e cinco \\ No ano do inverno forte \\ Por isso o cruel destino \\ Deu-me de bandido a sorte. \\ Meu avô foi muito rico \\ O meu pai foi abastado \\ Mas domadô me educaro \\ Porque aonde eu fui criado \\ O povo não apriceia \\ o home civilizado. \\ Ali se apriceia muito \\ É um cantadô, um vaquero \\ Um amansadô de potro \\ Que seja bem catinguêro \\ Um home que mata onça \\ Ou então um cangaceiro \\ O meu pai fez diversas mortes \\ Porém não era bandido \\ Matava em defesa própria \\ Quando se via agridido \\ Mas nunca guardô disfeita \\ Morreu por ser atrivido.
}

Conversamos por um bom par de horas. Ele lembrava das caçadas e me contava o jeito certo de caçar cotia. Aquele narrador ali diante de mim me fazia voltar lá pro Córrego dos Januários dos anos setenta. Eu chegava a me lembrar do gosto do café, das broas e dos biscoitos assados em forno de barro ou mesmo na 
panela de ferro. Mas ele lembrava que as histórias eram muito compridas, e que já lhe faltava tempo.

Seu Genorinho: E essa história, isso era 416 versos. Decorei tudo, mas decorei do princípio. Eles mandava eu contar e eu contava tudo. Aí depois o negócio do serviço foi apertano, eu larguei aquele trem pra lá, o negócio apertô memo, eu resorvi a casá. Aí eu esqueci, larguei...

Toquinha: O Senhor casou e esqueceu as histórias, Seu Agenor?

Seu Genorinho: Eu larguei aquele trem tudo pra lá. A única história que eu decorava pra eles lá, que eu falava pra eles lá e inda lembro ela é uma história do Zé Pretim, a história do Zezim mais a Mariquinha e a história do Lampião da Morte. Essas três. Mas o resto, umas história bonita que eu sabia, boba, uma história bonita tamém, Cancão de Fogo, mas era uma história mesmo, mas eu fui largano aquilo pra lá, os livro tamém foi sumino, cabô.

Toquinha: O Senhor se lembra de uma história que contavam de uma menina que ia procurar o príncipe dela e ela passava pela Lua, pelo vento, pela...

Seu Genorinho: Pois é, aquela história eu lembro dela ainda, aquela eu lembro. Aquela história é muito bonita. Muito bonita! Aquela é em prosa, né?

Toquinha: É, é em prosa. O senhor sabe história em prosa e em verso?

Seu Genorinho: E em verso, é. Ainda tem outra bonita tamém. Essa era rimada, mas eu esqueci ela tamém, gente. Pavão Misterioso.

Toquinha: Pavão Misterioso?

Seu Genorinho: Pavão misterioso. Ih, uma história bonita pra daná. Essa eu senti de ter perdido o livro dela. Até foi o Paulo que trouxe o livro pra mim lá de São Paulo. Ele veio aí e falou: ah, papai, um livro da história do Pavão Misterioso aqui, mas bonita pra disgraçá! Eu comecei a decorá ela. Depois não tem jeito não. Depois que a gente inventa serviço pra gente, apertado, a gente num tem prazo não. A gente esquece com aquela pertubação de serviço. Mas era muita história bonita que eu sabia, boba.

Nas minhas incursões no rastro das narrativas que me são tão caras, pesquisando na internet, encontro a história do livro perdido de Seu Agenor, o Pavão Misterioso, história mencionada com orgulho, porque, segundo ele, sabia ela decor $e$ salteado. Esse era o modo como a literatura chegava ao meu universo até a década de 80. Seu Genorinho foi um dos contadores de histórias que conheci dentre amigos de meu pai, tios e tias. E me deparei também com a história do Antônio Silvino, que ele reproduz parte dos 416 versos

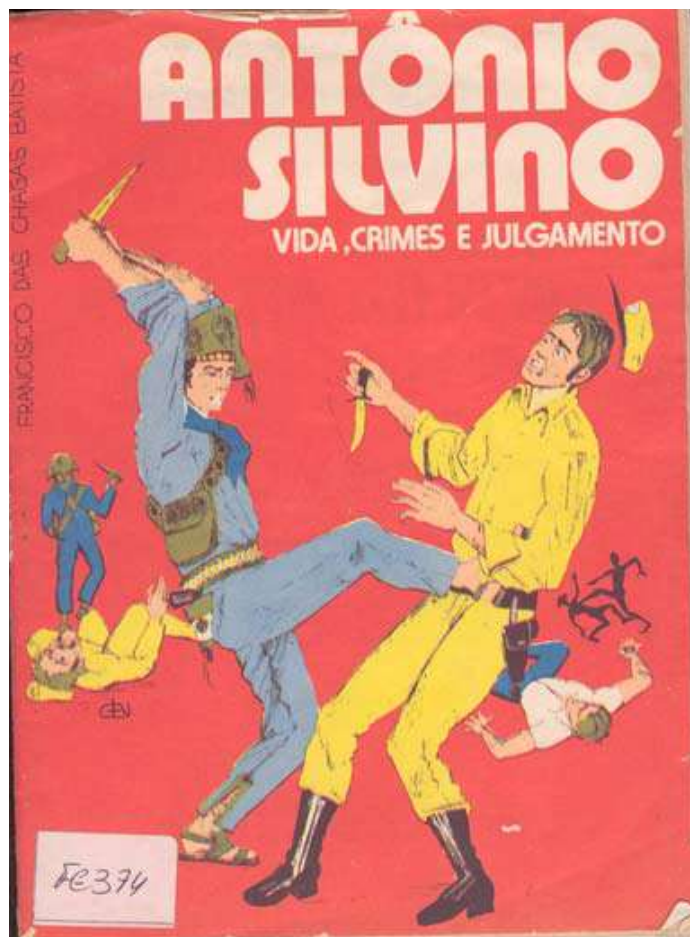

Figura 9: Antônio Silvino: vida, crime e castigo 


\section{COLEÇĀO LUZEIRO}

puavcisco das casgas matista

\section{ANTONIO SILVINO}

\section{VIBA. CRIMES E ILLGAMENTO}

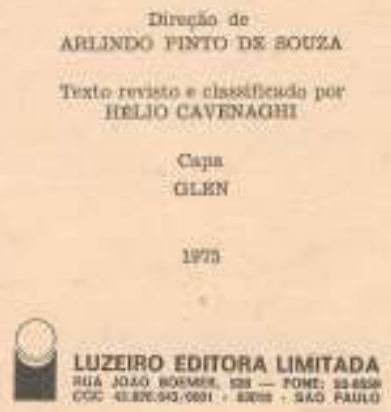

Figura 10: Antônio Silvino: vida, crime e castigo 2

\section{ANTÔNIO SILVINO}

\section{Vida, Crimes e Julgamento}

Leitor, em versos rimados Vou minha história contar, Os crimes que pratiquei Venho agora confessar. Jurando que da verdade Jamais me hei de afastar.

Pedro Batista de Almeida E Balbina de Morais, Casados catolicamente, Foram meus legítimos pais, Nascidos em Pernambuco E do Pajeú naturais.

Nas margens do Pajeú No distrito de Ingazeira, Junto à Serra da Colônia Vi o sol a vez primeira; Ao nascer trouxe nas veias Sangue da raça guerreira.

Nasci em setenta e cinco, Num ano de inverno forte, No dia dois de novembro, Aniversário da morte; Por isso o cruel destino Deu-me de bandido a sorte.
Meu avô foi muito rico E meu pai foi abastado, Mas não me mandou educar, Porque onde eu fui criado O povo não aprecia O homem civilizado.

Ali se aprecia muito Um cantador, um vaqueiro, Um amansador de potro Que seja bem caatingueiro, Um homem que mata onça Ou então um cangaceiro.

Meu pai fez diversas mortes, Porém não era bandido; Matava em defesa própria Quando se via agredido, Pois nunca guardou desfeita, Morreu por ser atrevido.

Enquanto eu era pequeno Aprendi a trabalhar, Chegando aos 14 anos Dediquei-me a vaquejar. Abracei aos vinte anos A profissão de matar. 
Figura 11: Antônio Silvino: vida, crime e castigo 3

Seu Agenor, narrador em verso e prosa, lembra que para narrar precisa de tempo. Seus afazeres de pai de família o impedem de contar com a frequência desejada, mas sempre foi conhecido na cidade por ser bom de prosa, por seu ofício de contador.

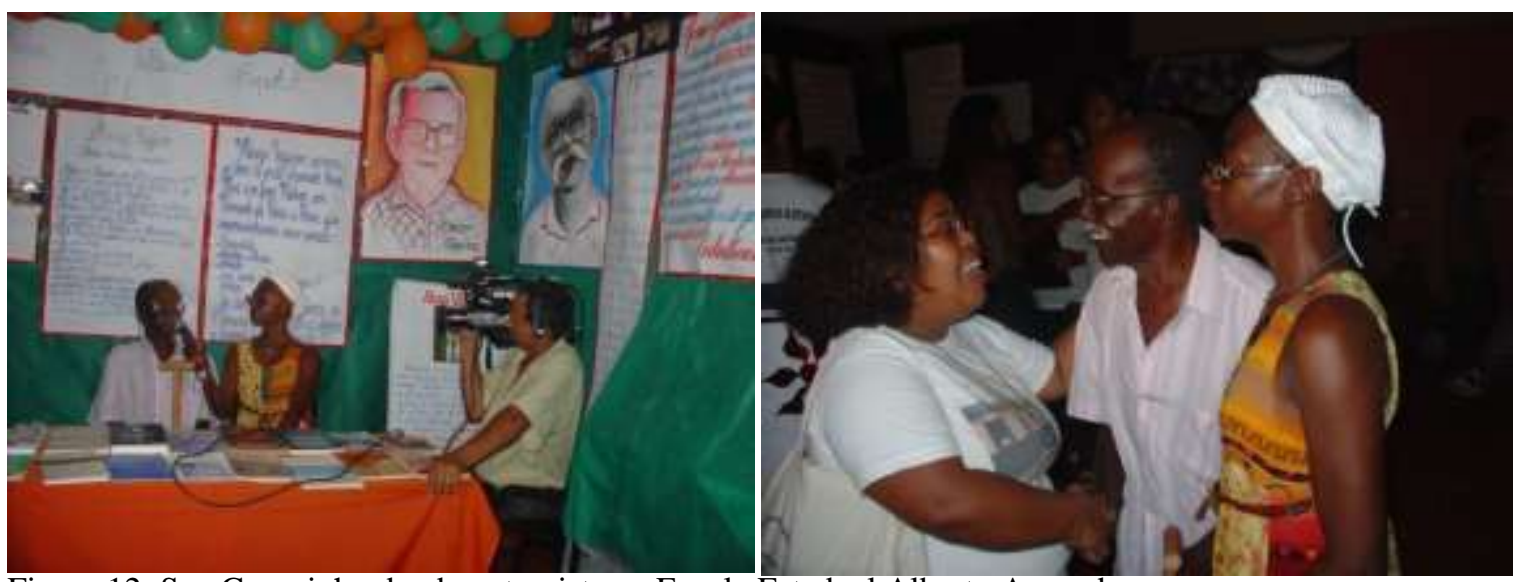

Figura 12: Seu Genorinho dando entrevista na Escola Estadual Alberto Azevedo

Figura 13: Meu rencontro com Seu Genorinho e sua filha Maria das Graças (Didi)

A filha Rosália, professora, 42 anos, lembra do pai com alegria, e se orgulha de que a cidade o tenha reconhecido no seu papel de contador de histórias e de causos.

Rosália: quando a gente era mais novo ele contava história quase todo dia. Morava na roça, não tinha luz, não tinha televisão, não tinha nada. A gente ficava sentado em volta do fogão e ele contava várias histórias interessantes. A gente amava! Era tudo de bom! Então, assim, é uma dádiva muito grande, ele ser meu pai, famoso contador de histórias. Ele contava muito bem as histórias, né. A gente até perguntou pra ele como que ele aprendeu a contar histórias, então ele contava pra gente que ele trabalhou de tropeiro muitos anos, então ele pegava tropa, né, viajava de um lugar pra outro com mantimentos, com café, milho, e ele tinha um livrinho de histórias que o homem que cuidou dele deu pra ele. Aí ele ia caminhando e lendo essa história, as histórias, aí ele aprendeu. Decorava, ele contava história em verso.

Toquinha: o Seu agenor era um contador mesmo, né, só o fato da gente conversar com ele, ele começava a contar. Eu gostava muito do Seu Agenor. Você lembra de histórias que ele contava?

Rosália: são tantas, menina! ele contava muito a história do Lampião, né. Era uma história bem bonita, do Lampião, que ele era cangaceiro, era uma história até real, ele foi real, e ele contava em forma de versos. Então eu achava muito interessante dela ser contada em versos. Muito bacana! Então a que me marcou mais foi essa. Era muito comprida, demorava bastante pra contar. E ficava todo mundo atento.

Rosália fala do pai com emoção. Lembra que ele era convidado para eventos na Escola Estadual Alberto Azevedo, que recebera medalhas, troféus por seus 
feitos de contador. E conta que sua irmã, Conceição, pretende lançar o livro "Histórias que papai contava", com as histórias de Seu Agenor.

Eu posso dizer que sou do tempo em que se dava e se ouvia conselhos. E muitos destes conselhos, destas lições, eram dados através de histórias. Na minha comunidade havia os conselheiros, pessoas que tinham o dom de falar. E sendo a minha comunidade formada por parentes, a tarefa de aconselhar e a de ouvir os conselhos era prática ainda mais corriqueira. E no ato de aconselhar muito era transmitido.

O senso prático é uma das características de muitos narradores natos. Mais tipicamente que em Leskov, encontramos esse atributo num Gotthelf, que dá conselhos de agronomia a seus camponeses, num Nodier, que se preocupa com os perigos da iluminação a gás, e num Hebel, que transmite a seus leitores pequenas informações científicas em seu Schatzkastlein (Caixa de tesouros). Tudo isso esclarece a natureza da verdadeira narrativa. Ela tem sempre em si, às vezes de forma latente uma dimensão utilitária. Essa utilidade pode consistir seja num ensinamento moral, seja numa sugestão pratica, seja num provérbio ou uma norma de vida - de qualquer maneira, o narrador é um homem que sabe dar conselhos. Mas se "dar conselhos" parece hoje algo de antiquado, é porque as experiências estão deixando de ser comunicáveis. Em consequência, não podemos dar conselhos nem a nós mesmos nem aos outros. Aconselhar é menos responder a uma pergunta que fazer uma sugestão sobre a continuação de uma história que está sendo narrada, Para obter essa sugestão, é necessário primeiro saber narrar a história (sem contar que um homem só é receptivo a um conselho na medida em que verbaliza a sua situação). $\mathrm{O}$ conselho tecido na substância viva da existência tem um nome: sabedoria. A arte de narrar está definhando porque a sabedoria - o lado épico da verdade - está em extinção. Porém esse processo vem de longe. Nada seria mais tolo que ver nele um "sintoma de decadência" ou uma característica "moderna". Na realidade, esse processo, que expulsa gradualmente a narrativa da esfera do discurso vivo e ao mesmo tempo dá uma nova beleza ao que está desaparecendo, tem se desenvolvido concomitantemente com toda uma evolução secular das forças produtivas. (BENJAMIN, 1994, p. 200-201).

Como frisa Benjamin, para o conselho há que ter escuta. Não é um responder perguntas, mas é lembrar que se faz parte de uma linhagem, que se faz parte de uma história que não deve ser partida, que é necessário que se conduza como um leito de rio evitando desvios, interrupções bruscas do caminho.

Para o ato de aconselhar era necessário sabedoria, argumento, paciência. Era um ato de transmissão, e para tanto esse conselheiro devia ser homem de boa palavra.

Nesse tempo em que, além do tempo lento tão caro ao narrador, tudo tinha sua cerimônia, não era hábito conversar livremente com os filhos ao orientá-los, conduzindo o processo educativo, de formação da pessoa. Era tempo em que se 
exigia obediência aos mais velhos, e, nesse cenário, muitos conselhos eram entendidos como repreensão. Mais tarde, já adulto, é que se entendia o valor, o efeito daquela conversa, daquela prosa-ensinamento.

Lá pelos Januários, a conselheira ou o conselheiro também eram vistos como mulher severa, ou homem severo, de palavra a ser obedecida, mas muitos lembram de tias e tios que conversavam sobre namorados, amigos mais velhos que sabiam dizer a palavra certa na hora necessária, os que transmitiam mensagens por rememoração, por lembranças do vivido, pela experiência.

Meu Tio Cândido, irmão de minha mãe, era desses que sempre evocava os antepassados, falava das saudades e dos ensinamentos. Era um apaixonado quando falava, discursava com veemência durante as rezas quando de suas visitas à família. Era um lembrador. Ele fora embora dos Januários ainda muito jovem, rumo ao Seminário, mas acabou desistindo da vida do sacerdócio, casou-se e foi morar em Manhuaçu/MG. Evocava sempre suas memórias de infância, seus aprendizados, a dureza dos tempos e a alegria. Muitas vezes chegava a ser dramático. As histórias tradicionais da família, a importância de respeitar certos modos de vida por serem guardiães da moral e dos bons costumes eram passadas para as novas gerações. Em momentos de reuniões fosse na igreja, fosse nas festas, eram lembrados nomes de pessoas que foram exemplos de formas de bem viver, de boa conduta, em quem se confiava.

Muitos tinham ideias novas, queriam outros rumos para suas vidas, e trilhavam seus caminhos apartados do que se esperava na calmaria daquele interior de Minas. Helena Inês de Souza, 75 anos, me conta, via facebook, como eram aqueles tempos em que cada um tinha seu papel, sua tarefa comunitária.

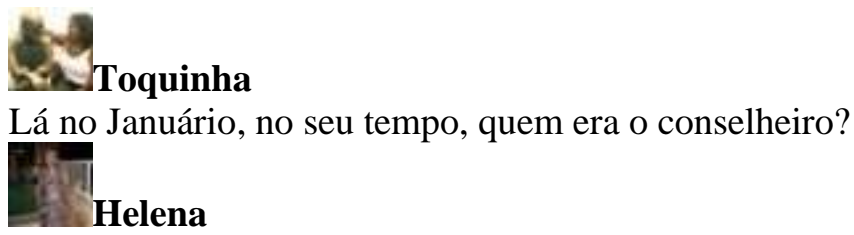

Era o tio Luís, Mas quando eu queria alguma coisa, não obedecia os conselhos de ninguém. Só ia a rezas porque era obrigada. Hoje eu entendo tudo isto. Dou muito graças a Deus. Ele abriu meus caminhos.

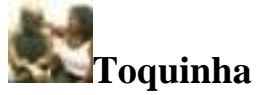

Ele era chamado para estes conselhos, para essas conversas? 


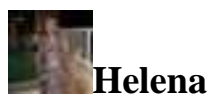

Sim. No dia que ele disse que eu teria que ficar lá no Januário eu disse a ele que viria para o Rio a pé, mas lá eu não iria ficar. Então ele concordou comigo.

Quando Helena diz "Então ele concordou comigo”, está dizendo que depois da conversa, do entendimento do desejo e da necessidade, fora respeitado o caminho escolhido por ela. Tio Luiz, do que sei, era paciente, entendia das medicinas raizeiras, das homeopatias, era nosso médico para as urgências mais corriqueiras, e quando o caso era mais sério era chamado o Dr, Tomás Lucas, médico conhecido de toda a região. E pelo visto, Tio Luiz tinha também um pouco de psicólogo, de cuidador.

Mas é certo também que muito havia de repressão, de cerceamento da liberdade, de vigilância, mas ainda a modernidade não chegara. Vivia-se do que era ensinado de pai para filho. A autoridade familiar, comunitária e religiosa era muito respeitada e muitas vezes temida. A sexualidade era reprimida, a religiosidade tinha muita força, e a instituição familiar era muito vigiada.

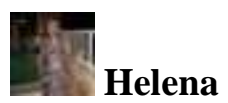

A repressão era muito forte. Por falta de conhecimento, e o domínio dado pela Religião castrava o ser humano. Você vê que hoje alguns estão dominados pelo medo. O filho da Dulce, o Francisco, me disse que ele era pequeno quando eu saí de lá, e a forma que eu saí. Disse que nunca tinha visto tamanha coragem como a minha, e disse também que todos me aplaudiram pela minha coragem.

Comunidade pequena onde todo acontecido corria de boca em boca todo e qualquer deslize de comportamento era observado, e as punições eram severas. Mas eram outros tempos, pouco conhecimento, faltava informação e psicologia. Se repetia com os filhos muito do que se aprendia com os pais, e seguia a vida. Mas muitos, como Helena Inês, seguiram seus destinos da forma que acharam mais conveniente. Saíram da comunidade em busca de um mundo que comportasse suas ideias avançadas, e acabaram abrindo caminho para outros. Mulher separada do marido voltava para a casa dos pais, e pronto. Mas Helena veio embora para o Rio de Janeiro sozinha e com filhos para criar, e isso naquele tempo era considerado afronta aos pais e aos costumes dos mais antigos. Rupturas. 
Naqueles tempos, para além dos contadores de histórias, havia os narradores com o poder de persuasão, de convencimento, homens e mulheres com o dom de palavrar. E esse dom já conferia à pessoa distinção e caráter. Eram homens e mulheres com alguma leitura, como costumavam dizer, ou com conhecimento de como tratar dos doentes com homeopatia ou ervas, que sabiam conduzir as novenas e festas da igreja. Um outro exemplo desse dom da palavra era o pedido de casamento onde o moço apaixonado e com intenções de casar recorria a alguém de respeito na comunidade para que este pedisse ao pai a mão da moça em seu favor. Muitas histórias desses episódios são lembradas ainda hoje.

Zé Barba: eu pedi bastante casamento.

Toquinha: como que era isso, como que chega na casa de alguém e pede um casamento pra alguém, pra outra pessoa?

Zé Barba: é muito fácil, Toquinha, é bão que ocê tem as condição pr'ocê falar com o pai dela, como que tá o negócio... Porque é ruim cê perder a buscada, né.

Toquinha: tem isso? O senhor tem que ganhar o negócio, igual aposta. (risos)

Zé Barba: aí cê tinha que falar: fulano pediu desculpa ocê, mas mandou falar com o senhor o seguinte: ele gosta muito da filha do senhor, se o senhor num faz muita questão dele entrá pra família do senhor. Chamava a mãe dela, o pai dela.

Toquinha: e a resposta era no mesmo dia?

Zé Barba: tinha que esperar uns quinze dias.

Seu Zé Barba é um desses homens que entendem os costumes de antigamente. E lembra seus tempos de moço em época de se casar. Conta que aprendeu a ler com Tio Sebastião Lau que escrevia na parede com carvão, e, quando paravam para o descanso na roça, escrevia na folha de bananeira.

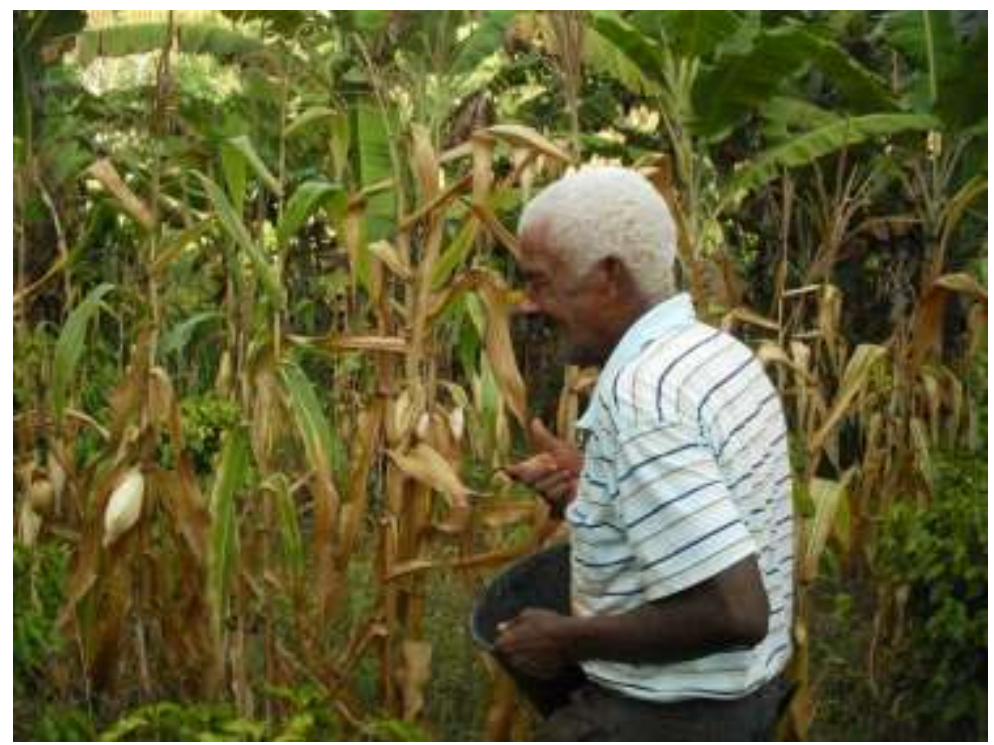

Figura 14: Seu Zé Barba (foto de Madson José) 
Zé Barba: ô Toquinha, parece que era um milagre, eu senti muito a morte do meu pai porque ele morreu com trinta e oito anos de idade, mas eu passei pra casinha do meu tio mais a minha mãe, foi mió que o meu pai ainda, o modo de criação. O negócio era o seguinte, Toquinha, com idade de nove anos a escola era o seguinte: ele passou pra mim o A-B-C, depois começou fazer as frase. Mas isso era na parede. Quando nós tava capinano lá na roça ele falava: vamo discansá mucado, José. E na foia de banana ele fazia aqueles nome, então foi indo. No fim ele comprou um manuscrito pra mim, quem sabia ler o manuscrito podia correr mundo. Eu num fui na escola não, eu aprindi as quatro operação, li o manuscrito. Era um livro, devia ter mais ou menos uma base de umas quarenta leitura. Cada uma com uma história diferente.

Toquinha: quando a pessoa conseguisse ler todo ele, o manuscrito, aí tava pronto? Zé Barba: Se ocê lesse o manuscrito ocê podia correr mundo, podia correr mundo.

Zé Barba: O acolhimento, Toquinha, tira muita gente da perdição, concorda comigo? Foi acolhido? Foi acolhido acabô, tem casa...

Seu Zé Barba se orgulha da família que constituiu, fala da importância do acolhimento. É homem positivo, como se diz por lá, fala com franqueza, e diz coisas poéticas também. Diz as coisas como elas são. E me recorda Paulo Freire, traz a importância do aprendizado do necessário, quando ler o manuscrito era o essencial para "correr mundo".

Mas, é importante dizer, a "leitura" do meu mundo, que me foi sempre fundamental, não fez de mim um menino antecipado em homem, um racionalista de calças curtas. A curiosidade do menino não iria distorcer-se pelo simples fato de ser exercida, no que fui mais ajudado do que desajudado por meus pais. E foi com eles, precisamente, em certo momento dessa rica experiência de compreensão do meu mundo imediato, sem que tal compreensão tivesse significado malquerenças ao que ele tinha de encantadoramente misterioso, que eu comecei a ser introduzido na leitura da palavra. A decifração da palavra fluía naturalmente da "leitura" do mundo particular. Não era algo que se estivesse dando superpostamente a ele. Fui alfabetizado no chão do quintal de minha casa, à sombra das mangueiras, com palavras do meu mundo e não do mundo maior dos meus pais. $\mathrm{O}$ chão foi o meu quadro-negro; gravetos, o meu giz. (FREIRE, 1987, p. 16)

As manifestações culturais típicas de pequenas cidades do interior que ainda sobrevivem nesse mundo considerado periférico hoje, muitas vezes ficam legadas ao campo do exótico, e não na sua verdadeira importância como constitutiva da nossa cultura como um todo. Constituem, na maioria das vezes, um adendo, o nosso folclore, contemplado muitas vezes apenas nos calendários escolares.

Essa cultura da narração de histórias tão característica de culturas tradicionais, populares, começa a ganhar outras nuances a partir dos anos de 1990. Pela minha percepção desta nova modalidade de narradores, a necessidade de comunicar essas práticas orais, a tentativa de preservá-las, foi se modernizando. Das cozinhas de chão de terra batida, das rodas em noites de lua cheia, das camas 
quentinhas com carinho da ama, dos pais ou da babá, essas histórias foram se trasladando para as bibliotecas, espaços recreativos, palcos. O clima intimista foi dando lugar ao espetáculo. $\mathrm{E}$ isso foi acontecendo sem alarde, nas tentativas de envolver as crianças em ambientes aconchegantes onde tivessem contato com o lúdico, com a oralidade e com o simbólico das histórias que sempre viajaram de boca em boca, mundo afora.

E começaram a ser organizadas oficinas para a aprendizagem da técnica de se contar história, e a serem formados grupos de contadores de histórias que se apresentavam em escolas, eventos culturais, teatros. Um dos primeiros grupos de contadores de histórias foi o Morandubetá, que tem uma história intimamente ligada ao desejo de formar leitores. Numa entrevista ao professor Julio Diniz, do Departamento de Letras PUC-Rio, o Morandubetá relata como foi esse início de um novo olhar para o contador de histórias, agora ocupando o cenário urbano.

Em 1989 aconteceu no Rio de Janeiro um curso de contadores de histórias com um grupo da Venezuela "En Cuentos y Encantos" formado pela venezuelana Isabel de los Rios e o brasileiro Luiz Carlos Neves, foram convidados por Eliana Yunes que era Diretora da FNLIJ - Fundação Nacional do Livro Infantil e Juvenil, onde trabalhavam também Lúcia Fidalgo, Maraney Freire e Inês Rocha. As quatro fizeram o curso e foram a semente do futuro grupo, mas ainda não era o Morandubetá. Nesse meio tempo o Celso Sisto entrou para a FNLIJ como especialista na área da literatura, e se juntou ao grupo. Começamos a nos reunir e contar histórias no instituto Nazareh, um colégio dirigido por Regina Yolanda que ficava na Rua Pereira da Silva, em Laranjeiras. Eliana participava da equipe pedagógica e nos levou para lá. Ali nasceu o Morandubetá. (PRIETO, 2011, p. 49$50)$

Segundo o grupo, a contação de histórias foi assumida como parte de um programa de formação de leitores, e o PROLER (Programa Nacional de Incentivo à Leitura) disseminou o trabalho. A narração urbana ainda era uma novidade, mas essa prática reintroduzia a narração na prática social do brasileiro, contam. E daí foram surgindo as oficinas, apresentações em feiras de livro, chegando ao teatro e daí à imprensa, tornando conhecida essa nova vertente da antiga atividade própria dos interiores do Brasil e do mundo.

Seguindo o fio dos encontros, eu não conhecia essa modalidade de contação de histórias. Rute Casoy ${ }^{4}$, por essas sortes ou destinos que a vida nos apresenta,

\footnotetext{
4 Rute Casoy Rute Casoy é psicomotricista, arteterapeuta, poeta, bordadeira, contadora de histórias, coordenadora da Roda de Histórias Indígenas, da Oficina Livre de Histórias e da Roda das Mulheres Sábias. Criadora do Atelier Véu de Poesia, projeto que agrega bordadeiras de
} 
me abriria portas para experimentar o ofício de contadora. Eu nunca me imaginei contadora de histórias, acho que talvez tenha sido essa uma das razões de eu ter buscado lidar com a escrita, um modo de lidar com as histórias. Eu não tinha modos, nem voz, para palco, público. Quando fui ao primeiro encontro do que viria a ser a Roda de Histórias Indígenas, fui por curiosidade, a convite de Denise Sampaio Gusmão. Era uma reunião, na Universidade Federal do Rio de Janeiro UFRJ, entre pessoas familiarizadas com esse universo dos interiores do Brasil, apaixonados pelas culturas tradicionais, pela cultura indígena. Alguns já haviam se encontrado em outras situações de vivência dessas manifestações da tradição como encontros com povos indígenas. Rute Casoy, Denise Gusmão, Claudia Bandeira, Ana Roberta (Bina) e Deodato Rivera me envolviam numa nova história. O grupo começou estudando alguns livros, um deles o "Brasil, outros quinhentos", do antropólogo argentino Néstor Garcia Canclini, um primeiro estudo em grupo do qual eu participava. Estudávamos entrando em contato com as narrativas indígenas pelas mãos de Rute Casoy, psicomotricista e arteterapeuta, que tinha um extenso conhecimento da cultura indígena tendo passado pela experiência de viver um tempo com um grupo indígena do Acre. Sua delicadeza ao lidar com o tema nos encantava a todos e ela, em encontros semanais, ministrava a sua "Oficina Livre de Histórias". E nossos encontros eram sempre muito lúdicos, com trabalhos corporais, desenhos, cantos em roda de inspiração indígena. E Rute me conta um pouco sobre sua forma de olhar para as narrativas da tradição.

Rute Casoy: Contar histórias é uma maneira de comunicação muito antiga e meio em desuso nos tempos atuais, tempos de tanta informação e tão pouca troca de experiência vivida.

As histórias são estruturas simbólicas, representantes do universo e do percurso da alma da pessoa em processo de perambular para encontrar-se, encorpar-se, realizarse e articular-se ao mundo.

As histórias da tradição oral têm força, não só pelo seu conteúdo de sabedoria de vida, mas também pelo exercício de revelar esta alma contida no interior de quem narra. Esta alma sabe e atua mobilizando energias intuitivas que discernem o que é suficiente, o que é possível, o que é atraente, o que alimenta, o que ensina e mostra o caminho.

Em geral as histórias da tradição oral atravessam florestas, mares, trilhas, castelos, aldeias, rios, lagos que são lugares onde o fio narrativo vai sendo tecido até revelar a paisagem por inteiro. Ao mesmo tempo que o fio entre o narrador e seus ouvintes

diferentes origens sociais para bordar poesia e histórias de vida em seu próprio atelier em Santa Tereza-RJ e em diversas comunidades. E é assessora pedagógica da "Universidade das Quebradas", curso de extensão da UFRJ para produtores culturais de periferia atualmente sediado no Museu MAR, RJ. 
vai evoluindo em movimentos que fazem a sintonia necessária para que a magia do encontro se dê. Esses espaços são labirintos desafiadores. Não há história que evolua fora da concretude destas difíceis travessias.

Aprendi muito sobre o universo dos povos da floresta, e fui experimentando o contar, soltar a voz, respeitar meu ritmo. Aquele grupo de companheiros de estudo me ajudava a perder o medo da fala, da expressão artística, a ganhar autoconfiança, e fui me permitindo contar algumas histórias, até que o grupo decidiu ganhar os palcos, se projetar para fora da nossa sala na UFRJ. Rute Casoy já fazia esse trabalho, mas não o nosso grupo. Foram dando linha à minha pipa e eu fui me soltando, quando vi estava contando histórias no Teatro do Jóquei e nos espaços recreativos do Rio Design Leblon e Rio Design Barra, no Rio de Janeiro, junto com Rute, Ana Luiza, Ana Gibson, Miza e Juliana Franklin. Foi uma ousadia, mas enquanto contava eu rememorava toda uma infância, toda uma prática tão de todo dia que tanto me havia ensinado. Eu aprendera algumas técnicas vocais, a sentir mais o meu corpo, mas Rute Casoy me ensinava que cada contador é um contador, e precisa respeitar o que tem dentro, e gostavam da minha voz calma, pequena, me diziam. Eu conseguia fazer minha voz chegar aos ouvidos de outros. Fiz parte do grupo até 2006, ano que entrei para a faculdade e não pude mais conciliar trabalho, estudo e a Roda, sendo posteriormente convidada a participar do Poranduba, contando "A Origem do Mundo", mito do povo Macuxi, junto com as antigas companheiras. O projeto, financiado pela PETROBRAS, incluía a gravação de quatro CDs com histórias de tradição indígena, livro com as histórias selecionadas e oficinas em escolas e outros espaços dedicados à educação.

E a nossa mestra no aprendizado do narrar nos falava sempre com muita delicadeza dessa sua experiência de ajudar outros a serem contadores

Rute Casoy: Os monges budistas, antigamente criavam parábolas para provar ao mestre que tinham aprendido a lei. A lei é sempre um aprendizado. Ninguém nasce sabendo das histórias. Um narrador é aquele que teve a oportunidade de ouvir muito, tanto que apreendeu, isto é, pescou este peixão simbólico que serve para alimentar entre outras coisas, como compartilhar e agradecer. Coisas que dão valor à vida e garantem a sua sustentação.

A prática da contar e de ouvir histórias, agora num outro contexto, me apresentava uma multiplicidade de sensações. Rute Casoy fala de seu cuidado ao trabalhar com as narrativas, e explica que sua "Oficina Livre de Histórias" tem 
sido uma forma de ajudar os que a procuram a descobrir suas potencialidades como narradores.

Rute Casoy: Meu método de preparação para a narração consiste, antes de mais nada, em fazer o cruzamento daquela história que está sendo preparada e a minha história de vida, para extrair um real ensinamento, percebo que estas histórias descontextualizadas perdem em significado sóciocultural, mas não perdem em simbologia e contribuem para enriquecer o vocabulário de imagens sobre os quais nossas experiência está baseada. O principal desafio consiste em, ao retirar as histórias de seu contexto sóciocultural, não cometer a traição de utilizá-las com um intuito anteriormente planejado. $\mathrm{O}$ meu intuito consiste em tão somente demonstrar ser possível lançar mão de simbologias de outras culturas para expressar questões da minha subjetividade, levando em conta sermos todos humanos e universais.

A Oficina visa instaurar, em cerca de 8 encontros, um processo criativo em torno das histórias apresentadas, numa construção coletiva.

Nosso programa desdobra-se em etapas, que serão percorridas no decorrer dos trabalhos, através de vivências, técnicas, referências teóricas e práticas visando gerar um ambiente propício ao exercício da narrativa e promover o desenvolvimento, a autoconfiança e o estilo próprio do contador de histórias.

OFICINA é um lugar onde muitas coisas são inventadas, criadas, restauradas, consertadas e/ou transformadas. Este é o conceito que melhor define nossa abordagem em relação às histórias da Tradição Oral de todo mundo que estamos pesquisando.

LIVRE, porque utilizamos uma metodologia que permite aprofundar a leitura para libertar a expressividade corporal, lúdica e artística dos textos.

Este trabalho é aberto a todas as pessoas, que por diversos motivos queiram fazer uma formação nesta velha arte, tanto para conhecer um vasto acervo DE HISTÓRIAS, quanto para desenvolver a capacidade de contá-las, tornando-as atraentes e significativas.

Acreditamos que todos têm potencial para desenvolver esta habilidade.

Um terceiro grupo que vem trabalhando também com contação de histórias, mas de forma bastante distinta do Morandubetá e da Roda de Histórias Indígenas é o Tapetes Contadores de Histórias. Cada grupo tem sua forma de lidar com o ofício de contar. A oralidade vai ganhando roupagens, atrativos para cativar o público. Nesses espaços mais "cosmopolitas", de tantas linguagens possíveis, a oralidade vai delineando contornos de novidade, mas levando no bojo dos fazeres, da lida com as narrativas, suas experiências em outros campos como o teatro e as artes visuais. E cada grupo encontra seu jeito de interagir com um público que, por mais urbanos que sejam os novos espaços por onde as histórias têm andado, há sempre o desejo de intimidade, de falar mais de pertinho, de encontrar a característica tradicional dos narradores.

Os tapetes contadores de histórias: Somos um grupo de atores e contadores de histórias que desde 1998 produz e realiza espetáculos, sessões de histórias, 
oficinas, exposições interativas e projetos culturais que envolvem oralidade, artes visuais e teatro. Criamos e nos utilizamos de objetos (tapetes, painéis, malas, aventais, roupas, caixas e livros de pano) como cenários de contos autorais e populares de origens diversas, a fim de despertar o imaginário de crianças, jovens e adultos para as artes e a leitura. Formados em Artes Cênicas pela UniRio, nossa pesquisa tem como base os contos de tradição oral e da literatura em geral, e as intersecções entre oralidade e artes visuais.

Para nós, contar e escutar histórias proporciona uma qualidade de contato entre as pessoas que permite um profundo e prazeroso intercâmbio de experiências: atua tanto na construção de valores como contribui para a formação de uma percepção crítica e sensível da vida, da arte e da sociedade.

Diferente do meu Tio Geraldo, dos Genorinhos e tantos outros que usavam apenas o próprio corpo e a própria voz para levar as histórias até seus ouvintes, os "modernismos" no ato de narrar vêm favorecendo um entrelaçamento entre contadores, ouvintes e leitores. Cada vez mais se investe na ideia de o contador de histórias ser um formador de leitores trabalhando a partir de livros, haja vista os eventos nas feiras literárias, as bienais do livro no Brasil e mundo afora.

Os grupos citados e muitos outros têm suas raízes na tradição, mas vêm renovando os modos de contar, se adaptando aos novos tempos inserindo novos elementos, utilizando recursos que atraiam neste universo cada vez mais dominado pelas imagens, pela pressa, pelo lazer com dia e hora marcados.

O universo das artes se alimenta de troca de experiências, do intercâmbio de ideias, da interlocução. No caso do contador de histórias, o que o alimenta é a interação entre narrador e ouvinte. Um desses eventos que oportuniza interações foi inspiração para que Benita Prieto ${ }^{5}$ criasse o Simpósio Internacional de Contadores de Histórias, que acontece desde o ano de 1999. Prieto me conta que a motivação para criar o Simpósio surgiu quando, em 1996, saiu do Brasil para contar histórias no Encontro de Contadores de Histórias da Feira de Livros de Buenos Aires. Fascinada com os contadores argentinos e uruguaios, ela pensou: se tem na Argentina, terá no Brasil, e maior. Segundo Benita, a gota d'água foi uma outra viagem para fora do país, para participar do Festival Internacional del Cuento, em Los Silos, província de Santa Cruz de Tenerife, nas Ilhas Canárias/Espanha. Desde então organiza, no Rio de Janeiro, um grande encontro de contadores de histórias brasileiros e estrangeiros onde acontecem mesas

\footnotetext{
${ }^{5}$ Contadora de Histórias do Grupo Morandubetá, Atriz, Escritora, Produtora Cultural, Especialista em Literatura Infantil e Juvenil e em Leitura: Teoria e Práticas. Presidente do Instituto Conta Brasil e da Prieto Produções Artísticas. Coordenadora da Red Internacional de Cuentacuentos. Vive no Rio de Janeiro. Narra em Português e Espanhol.
} 
redondas, oficinas, Mercado da Palavra e Maratona de Contos. É na verdade uma grande festa de intercâmbio de histórias. Durante o Simpósio muitas experiências e modos de narrar têm a oportunidade de compartilhar o mesmos espaços, de ocupar distintos endereços pela cidade com o intuito de contar histórias.

Essas iniciativas, a meu ver, vêm responder à demanda dos novos tempos. Se tenho um carinho muito grande pelos meus tempos de infância em que os modos de vida permitiam experiências tão cheias de significados, é porque ainda hoje eles povoam lugares muito especiais nas minhas lembranças, e se os tempos são outros, o mundo é outro, as histórias também são outras. É assim desde que o mundo é mundo.

Neste meu percurso de encontro e encanto com narrativas e narradores, muitos foram os caminhos. Rememoro personagens e momentos que fazem parte da história de muita gente. Do Corrego dos Januários ao Rio de Janeiro, refaço a trilha dos cuidados, dos afetos, do aprendizado pelas palavras que andam de boca em boca e se derramam num mar de alegrias. 


\section{3 \\ Por parte de mãe}

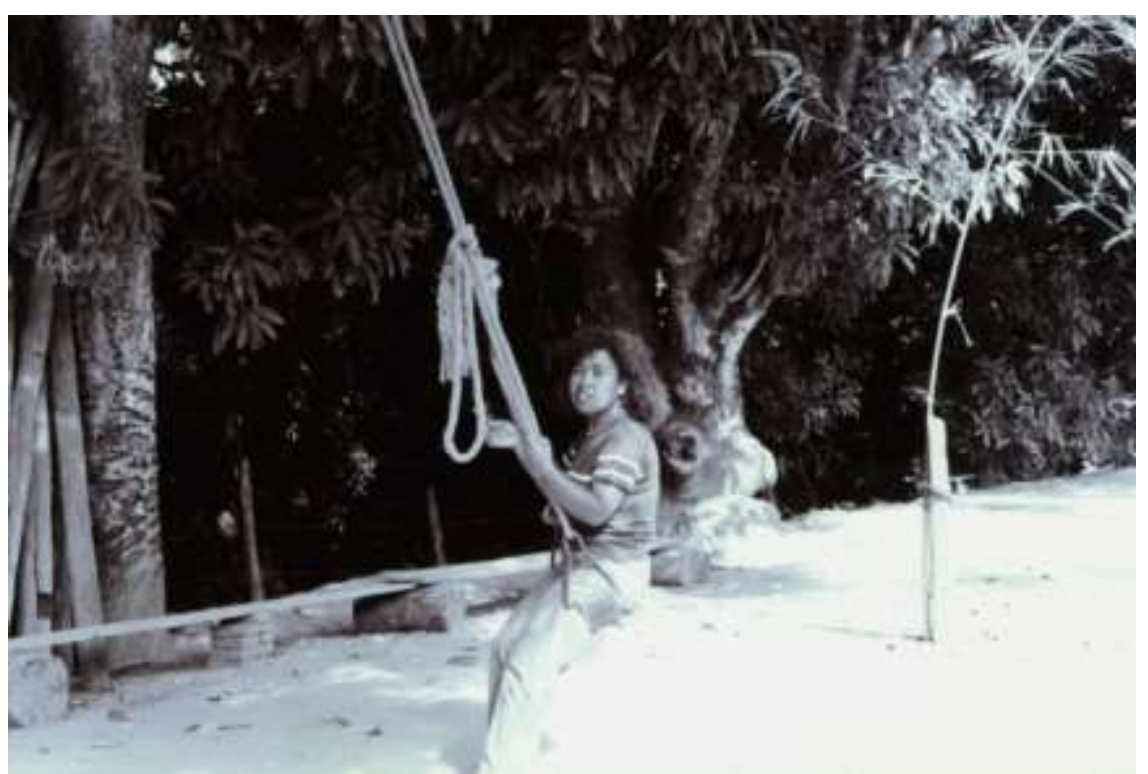

Figura 15: Toquinha no balanço (Foto de Denise Gusmão)

És um senhor tão bonito

Quanto a cara do meu filho

Tempo tempo tempo tempo

Vou te fazer um pedido

Tempo tempo tempo tempo...

Compositor de destinos

Tambor de todos os rítmos

Tempo tempo tempo tempo

Entro num acordo contigo

Tетро tетро tетро tетро...

Que sejas ainda mais vivo

No som do meu estribilho

Teтро tempo tempo tempo

Ouve bem o que te digo

Tempo tempo tempo tempo...

Peço-te o prazer legítimo

E o movimento preciso

Tempo tempo tempo tempo

Quando o tempo for propício

Tempo tempo tempo tempo...

De modo que o meu espírito

Ganhe um brilho definido

Tempo tempo tempo tempo

E eu espalhe benefícios

Tempo tempo tempo tempo...

$O$ que usaremos pra isso

Fica guardado em sigilo

Tempo tempo tempo tempo

Apenas contigo e migo

Tempo tempo tempo tempo...

(Gilberto Gil) 
A construção de um percurso não é uma ação solitária, ela se dá no entrecruzamento de histórias. E já, então, não é um percurso, mas muitos percursos de muitos afluentes que acabam por desaguar no grande rio onde todas as águas se juntam. A experiência da existência requer, como escreveu Guimarães Rosa, coragem. A coragem para enfrentar o inesperado, que pode ser de enfrentamento ou de encontro. No percurso que faço optei por narrar, a parte que me cabe, pelo viés dos encontros, e através deles dialogar com alguns companheiros nessa viagem.

A formação de uma comunidade, de um grupo, se dá pelas relações entre os envolvidos. E para essa conversa meio ao pé da fogueira, convido Francisco Van Der Poel, o Frei Chico, padre franciscano holandês que chegou ao Brasil em 1967, e tornou-se um dedicado pesquisador da cultura do Vale do Jequitinhonha, que diz que onde não há comunidade nenhuma cultura sobrevive, pois é nessa perspectiva que quero tratar de alguns pontos que marcam a relação entre a cultura da oralidade e a cultura da leitura e da escrita, fragmentos de pensamentos que têm norteado minha vida acadêmica e de autora literária.

Frei Chico: O que acaba com a cultura é quando acaba a comunidade. Inclusive, a adaptação da cultura popular, se ela acontece, e não só a adaptação, a renovação, ou criar coisas novas, se ela acontece na comunidade o próprio bom senso do grupo garante uma certa objetividade, uma garantia que essa cultura tá num bom caminho. E não é o especialista que vai dizer como uma comunidade tem que se comportar. Entente? Então pra mim a sobrevivência da cultura, a renovação da cultura tem tudo a ver com a própria comunidade. E, quando acaba a comunidade nenhuma cultura sobrevive não. (trasnscrito do filme "Quando acaba a Comunidade nenhuma cultura sobrevive".)

As raízes dessas ideias com as quais venho lidando estão fortemente plantadas na comunidade rural do Córrego dos Januários, Inhapim - MG, essa comunidade que me constitui como sujeito da minha própria história e da história de parceiros no aprendizado vida afora. Eliana Yunes lembra que o ato de ler lida com a nossa memória de experiências que ganham vida, nos convoca a lembrar que somos parte de tudo que nos cerca.

É na série de memórias evocadas trazidas pelo ouvir/ler/pensar as histórias do mundo e dos livros, que algumas identificações vão ganhando forma e ajudando no perfil que vamos desenhando, e corrigindo, de nós mesmos, a todo tempo. $\mathrm{O}$ ato de ler, porque implica a memória de experiências que se vão avivando, convoca-nos a pensar e dizer quem somos nós por meio daquilo que dizemos sobre tudo o que nos 
cerca. Esse contexto é, em verdade, compartilhado com muitos outros que influenciam nossas histórias e memórias. (YUNES, 2009. p. 27)

Se falo a partir de uma experiência pessoal é porque transformações muito profundas se deram na minha vida, e essas transformações estiveram e estão sempre muito ligadas à relação de amor com a terra onde nasci e com os que lá vivem. O meu desenvolvimento cultural, a minha entrada na universidade e no mestrado estão condicionados ao desenvolvimento cultural e social do meu lugar, da minha gente, das coisas que acredito serem muito importantes. Parto de uma situação concreta, particular, mas que não é um caso isolado, é uma amostra, pois me coloco apenas no lugar de um nome, uma referência para se pensar a relação de comunidades com suas próprias culturas, com suas próprias histórias e o contato com outras histórias, outras culturas.

Desse espaço delimitado, de onde eu conheço a geografia, a história de fundação, das famílias que se foram formando ao longo do leito do Córrego dos Januários, vou descobrindo pedaços, fragmentos de memória que vão ligando essa comunidade a outras, pontos de contato com histórias que de certa forma se repetem, têm raízes num mesmo passado mais longínquo. Manifestações que são memórias de outros povos indígenas, de Àfrica, Portugal, Espanha talvez e quantos outros. As cantigas de roda, as de ninar, as comidas e suas formas de preparo nos indicam que somos uma comunidade que foi gerada a partir de outras.

Vou reconhecendo nos eventos culturais que marcaram desde infância a mim e os de toda uma geração, e que ainda hoje têm uma força que permanece quando recordadas de memória, as marcas de uma tradição, de costumes e crenças que vêm de longe. A solidez dessas manifestações culturais, na sua maioria ligadas à igreja, encontra ressonância teórica nas palavras do pensador russo Michail Bakhtin, pois eram genuínas, criadas pela própria comunidade, e mesmo fazendo parte de rituais comuns à religião, traziam em si a essência da festa que congrega, que, no fim das contas, celebra a vida. E para esta celebração do simples impregnado de arte, o que importava era a comunhão, o sentido de comunidade. Eram festas de tradição religiosa, popular. E na arte popular essa implicação entre vida e arte fica muito explícita, pois a matéria prima é a vida cotidiana, simples, do povo. Uma construção coletiva. E experienciar a alegria presente na preparação dessas festas, que só poderia nascer ali, naquelas 
circunstâncias, entre aquelas pessoas, pois tudo era construído num universo de consenso discursivo, deixou uma memória que é sempre lembrança de um tempo bom. Ou seja, éramos uma grande família que se irmanava. E era a festa necessária do trabalho, da comemoração, do descanso da labuta diária, da segunda vida, nas palavras de Bakhtin. No tempo da colheita, nos finais de ciclos da lavoura, a acabada do café ${ }^{6}$, o fazer a farinha, produzir a rapadura, o queimar dos tijolos na olaria de meu pai e seus irmãos, tudo virava festa. E dentro da própria comunidade surgiam os poetas circunstantes, de ocasião, os fazedores de verso. Isso se dava pela ocasião da páscoa e nos bailes ou pagodes, como eram chamados os encontros para dançar ao som da sanfona e violão na casa de algum dos moradores. Aí surgiam os namoros, os casamentos, motivos para outras festas. Mais genuíno, impossível.

O carnaval é a segunda vida do povo, baseada no princípio do riso. É a sua vida festiva. (...) As festividades (qualquer que seja o seu tipo) são uma forma primordial, marcante, da civilização humana. (...) tiveram sempre um conteúdo essencial, um sentido profundo, exprimiram sempre uma concepção do mundo (BAKHTIN, 1993, p. 7)

Essa condição genuína da festa ganhava seu auge na malhação do Judas. A carnavalização era expressa na galhofa. $\mathrm{Na}$ noite de sábado de Aleluia, os responsáveis pela festa se dividiam em dois grupos, um ia para o mato fabricar o boneco a ser malhado e outro ia roubar os objetos para compor o reino passageiro do traidor de Jesus. Havia festa durante toda a Semana Santa e a festa do Judas encerrava as festividades na tarde do domingo de Páscoa. Os versos dos nossos poetas, inesquecíveis, os versos e os poetas, contavam histórias de um Judas namorador e contador de vantagens, à procura de uma moça para casar, mas que não conseguindo noiva, e descoberto seu ato de traição, era morto ao fim da festa. Nestes versos, escritos num português longe do considerado padrão da língua, mas que fazia parte da troça com o boneco, os nomes das moças solteiras de cada casa eram mencionados como desejadas do ilustre pretendente. E era uma farra só, com muito riso.

\footnotetext{
${ }^{6}$ A acabada do café é quando termina a colheita do café e todos que trabalharam naquela lavoura são convidados para a festa em agradecimento pela fartura, pela conclusão do trabalho.
} 


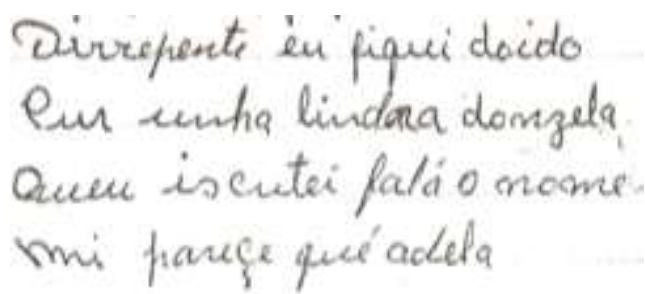

Prots estas nuin parecer: Gu eanssei de isperár Giui pra easinha dissima Baningo Bulidancicat

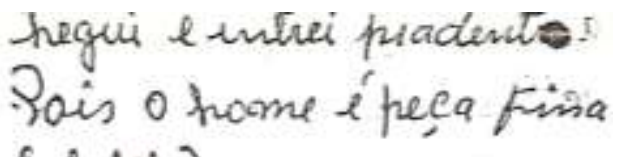
Ef fali' do cmeu amore Com a garóto dervalina
Dirrepente eu fiquei doido Pur unha lindra donzela Queu iscutei falá o nome Mi parece qué Adela

Versos do poeta Zé Chico)

Ainda muito menina, observava tudo aquilo com os olhos da beleza e da graça. Encantada. Tudo era nutrido de uma verdade incontestável: era vida. Mas era também, arte da mais pura. Zito Mesquita, irmão de Zé Chico, lembra dessa época e faz uma certa crítica ao ato de "malhar o Judas". Mas naquele tempo, como diz o próprio Zito, o povo se divertia com aquilo.

Zito: mas esse negócio do Juda, é engraçado, hoje se fizé esse negócio do Juda eu sou capaz de num ir não. Num ir lá assistir não, porque a pessoa vai panhano uma certa... ocê num pode condená aquele que perdeu ali. Então fazia aquele negócio: nove hora da manhã vai matar o Juda. Um levava espingarda, outro levava garrucha, outro punha um porrete na mão, um cabo de enxada. E quando dava aquela hora assim, o compadre Izalpino fazia aquele negócio, eles falava pisquim. Quem vai fazer o pisquim? Era o Izalpino. Sempre era ele que fazia, ficava a noite inteira, até o dia amanhecer, fazendo aqueles versos. Escrevia um caderno às vez com quinze, vinte folha, fazendo verso.

E Zito lembra um dos versos e explica que às vezes o mote para os versos era outro. E lembra da vez que, com os versos, os objetos roubados eram restituidos aos verdadeiros donos.

Zito: Aí fizero um verso pra madrinha Armerita, ela tinha uma cabrita. As coisa que robava do Juda, repartia. Nos verso repartia as coisa do Juda. 


\begin{abstract}
A vaca do rabo chato eu deixo pra Armerita dá três ciué de leite a danada da cabrita.
\end{abstract}

Mas lá pelo Córrego dos Januários era a singeleza dos versos, a troça entre amigos, uma festa religiosa que a fé do povo entremeava com um tanto de humor e irreverência.

Mais tarde, já adulta, pude distinguir a vida da arte, e para aprender a fazer arte tendo como matéria a minha observação do vivido, comecei a ler os grandes autores e estudar literatura, pois eu queria ser fraseadora, ao modo do poeta matogrossense, exaltador das pequenos acontecidos do cotidiano, Manoel de Barros.

Mas esse tal de fraseador bota mantimento em casa? Eu não queria ser doutor, eu só queria ser fraseador. Meu irmão insistiu: Mas se fraseador não bota mantimento em casa, nós temos que botar uma enxada na mão desse menino para ele deixar de variar. A mãe baixou a cabeça um pouco mais. O pai continuou meio vago. Mas não botou enxada. (BARROS, 2010, p. 39)

Mas por um tempo eu, fraseadora, não botava mantimento em casa. Era preciso me apossar de enxada e garantir o próprio sustento. Mas o Ser fraseador morava em mim e comigo permaneceu. Muitos outros foram aparecendo na minha vida e começaram a me mostrar caminhos. Esse outro, tão caro a Bakhtin, foi fundamental na minha experiência de vida e na minha arte.

As experiências pelas quais tenho passado como escrevedora, contadora das histórias da minha gente, são minhas por parte da mãe comunidade cultural que me constituiu sujeito sensível às culturas ligadas ao povo, à simplicidade, genuínas e necessárias para que permaneçam vivas, a comunidade e a cultura. Para falar dessa minha herança cultural comunitária quero escrever nas paredes essa relação de encontro com mundos muito diferentes que me fizeram querer olhar para o meu próprio mundo com mais respeito, apropriação e cuidado. A minha linhagem é a das coisas simples e fundamentais, e a minha estrada, meu norte, uma incógnita que vai se realizando nos encontros.

Os caminhos que me levariam ao encontro amoroso com o livro, ao prazer da leitura, foram tortuosos. Ainda cursando séries do que hoje conhecemos como Ensino Fundamental II, lendo Jorge Amado, eu pensava, ingenuamente: ele conta histórias da sua Bahia; e me perguntava: quem vai contar as histórias dos 
Januários? Por que as histórias da minha gente, as minhas histórias bonitas ou mesmo as tristes e comoventes, outras cheias de poesia, não eram contadas por ninguém? Pelo menos não assim em livros pra todo mundo ler. Eu cheguei à conclusão de que elas não eram escritas porque não eram importantes. Mas aquilo me incomodava demais. Eu pensava que histórias que tivessem aquelas nossas brincadeiras de criança, que falassem das festas que se fazia, das histórias de amor que aconteciam por lá iam ser bonitas demais e muitos iam gostar de ler. E eu tinha vontade de ser escritora para poder contar essas histórias, mas eu não sabia escrever bonito como eu achava que devia ser. A escola não imprimia em mim o desejo de leitura e de escrita. Certa vez, já cursando o primeiro ano do que hoje se conhece como Ensino Médio, naquelas conversas de fim de ano em que tradicionalmente se pergunta o que de fato a gente quer fazer como profissional, eu disse que queria ser escritora, e a professora disse: então escreva! E só. Eu havia dito aquilo na intenção de que ela, que tinha livros publicados, se interessasse pelo meu desejo e pudesse me indicar caminhos, mas nada. Eu nunca esqueci isso, como também não esqueci a única professora de literatura que me fez entender um pouquinho o que era literatura, a professora Erci. Ela falava sobre denotação e conotação, e, como exemplo, leu pequenos textos em que tinha as expressões que nunca mais esqueci: nuvens plúmbeas e baldes de luz dourada. Depois dessa aula nós escrevemos pequenos textos em que deveriam estar presente exemplos de denotação e de conotação. Lembro que depois disso eu escrevi um breve texto de que todos gostaram muito e foi para o mural do colégio. E lembro também de uma redação, na $6^{\text {a }}$ série, que ficou em terceiro lugar na sala e foi representada em teatro. E é só. Bem mais tarde, ao ler "Cem anos de solidão", de Grabriel Garcia Márquez, eu entenderia que se pode, pela literatura, inventar cidades, países, galáxias, subverter a língua. Até então eu nunca havia pensado que eu também tinha o poder de criar.

Mas o que eu queria mesmo, desde muito cedo, era ser professora. Achava lindo aprender e queria um dia poder ensinar! E ser escritora. Uma professora que escrevesse histórias. 


\section{1}

\section{Bolivar e Floripes, os meus pais}
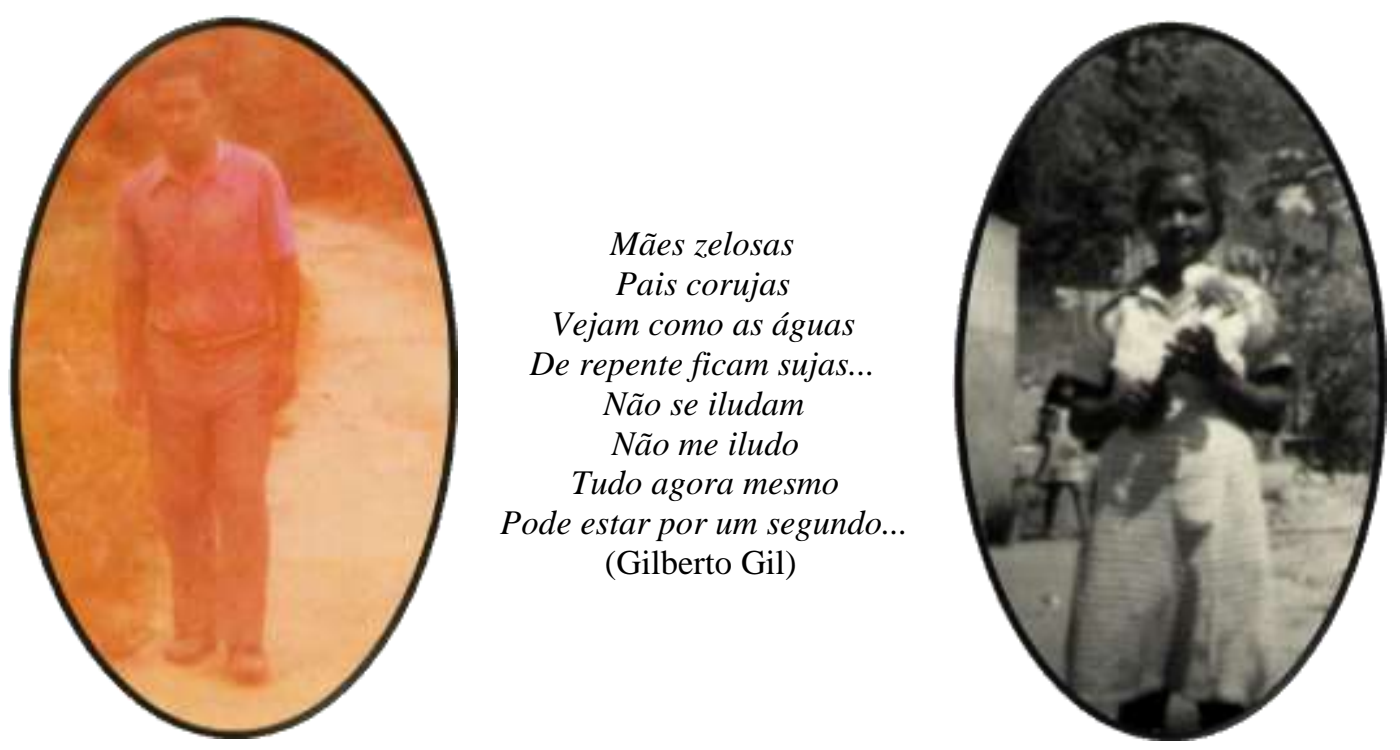

Figura 16: Bolivar Figura 17: Floripes

Meu pai, Bolivar, era homem de grande respeito na comunidade, incentivador de que participássemos de atividades culturais, tentativas de arte, que fizéssemos encenações na igreja e de que estudássemos, pois o estudo era a única herança que nos deixaria, como dissera certa vez.

Minha mãe, Floripes, gostava de música e de flores, tinha as mãos abençoadas para plantar roseiras, que enfeitavam a frente do nosso lar, além de fazer um feijão como poucas mães sabem fazer e que ficou na memória gustativa de muitos que frequentavam nossa casa. Lembro-me dela vestida de São José numa dramatização que fizemos numa comunidade vizinha, o Córrego do Belém, onde morava seu irmão, meu tio Sebastião. Mas eles faleceram em 1982, ele, nas férias de julho, ela, na véspera de natal. Eu tinha então quinze anos. Se eu fosse poeta naquela época gostaria de ter escrito o poema que a poeta Adélia Prado (1991, p. 116) escreveu, e que diz de todo o meu sentimento naquele momento de incertezas da adolescência me sentindo obrigada a tornar-me adulta em três tempos. No poema dela eu só mudaria: dói-me a cabeça aos 15 anos...

Dói-me a cabeça aos trinta e nove anos.

Não é hábito. É rarissimamente que ela dói.

Ninguém tem culpa. Meu pai, minha mãe descansaram seus fardos, não existe mais o modo 
de eles terem seus olhos sobre mim.

Mãe, ô mãe, ô pai, meu pai. Onde estão escondidos?

É dentro de mim que eles estão.

Não fiz mausoléu pra eles, pus os dois no chão.

Nasceu lá, porque quis, um pé de saudade roxa, que abunda nos cemitérios.

Quem plantou foi o vento, a água da chuva.

Quem vai matar é o sol.

Passou finados não fui lá, aniversário também não.

Pra quê, se pra chorar qualquer lugar me cabe?

É de tanto lembrá-los que eu não vou.

Ôôôo pai

Ôôôo mãe

Dentro de mim eles respondem

tenazes e duros

porque o zelo do espírito é sem meiguices:

Ôôôoi fia.

Foram anos muito difíceis os que se seguiram. Nunca me sentira tão sozinha no mundo. A dor pela perda dos dois me adoeceu e eu vim para o Rio de Janeiro trazida por minha irmã Terezinha para cuidar da minha saúde. Chegando ao Rio fiquei vivendo na casa em que minha irmã trabalhava como empregada doméstica/cuidadora de D. Carminha; aí conheci Gisélia, mãe de três filhos já adultos, filha de D. Carminha, que me escrevia cartas desde quando eu tinha 12 anos de idade - essas cartas sempre eram escritas em papéis lindos e sempre me emocionavam porque diziam coisas lindas, que ela gostava de mim porque me conhecia através das histórias que minha irmã contava de nossa família. Gisélia me levava para passear por Copacabana e me dava de presente livros de uma coleção destinada a adolescentes chamada "O amor de todos os tempos", que se vendia em bancas de jornal. Ganhei uns 4 ou 5 da série. Eu gostava daquelas histórias, e uma delas me marcou, pois contava a triste história de uma menina que vivia numa casa em que era indesejada e sem saber que era uma das filhas. Uma gata borralheira dos anos oitenta.

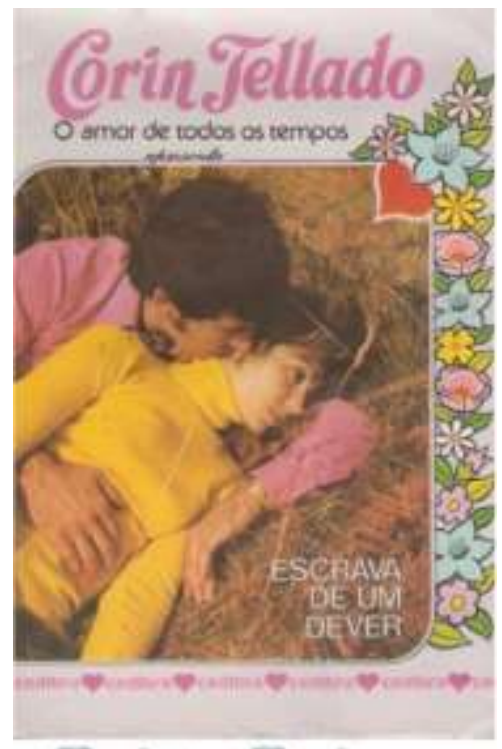

Figura 18: Livro "Ëscrava de um dever"

Anos mais tarde, a alma mais sossegada, escrevi o conto Simplesmente amor dedicado aos meus pais e às minhas irmãs. 
Nascida lá nos cafundós do mundo, sob os olhares severos e carinhosos da existência. Planos, ela jamais teve desde que lhe deram o nome de Felizarda Esperança, por conta de um sonho compartilhado pelos pais na véspera de seu nascimento: uma menina morena, de olhos muito verdes, que sorria ingenuamente. Tal riso, segundo eles, tinha o poder de dispersar a escuridão e suplantar as mazelas do dia-a-dia. Tendo a filha nascido muito parecida com a imagem vista pelos dois, acharam por bem batizá-la com o mesmo nome. (...) Apaixonou-se por um homem que apareceu numa noite de delírios. Antes mesmo de sentir o sangue que a iniciaria na arte de ser mulher, se viu perdida. Sentia-se febril. Felizarda Esperança via-o cruzar cidades inteiras, atravessar rios e montanhas. Lugares descritíveis apenas por ela. Foram meses de caminhada que ela por fim se viu amedrontada com a possibilidade de conviver para sempre com aquele ser capaz de fazê-la resistir a noites de sono, pois assim se livraria de sua presença invisível.

Apesar da angústia, guardava tudo em segredo. Certa madrugada não suportou o sono e dormiu. Então ele apareceu sentado na montanha, diante de sua janela.

Nunca o vira tão definido. (...)

A moça acordou sobressaltada. (...)

Passou o resto da noite em claro. Levantou muito cedo e tratou de ocupar-se da rotina. Antes que os pais acordassem, alguém bateu na porta. Ela atendeu enquanto secava o rosto suado apesar do frio daquela manhã. Foi como se abrisse a própria alma.

Um homem a cumprimentou e ficaram se olhando como se estivessem diante

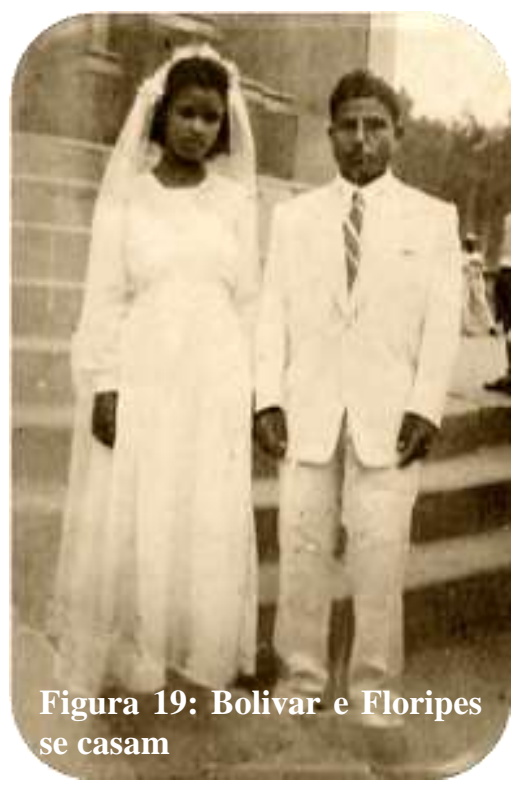

Pensou: é saudade do meu Feliciano, mas ele daqui a pouco vai chegar, deve ser isso.

Enquanto esperava resolveu reformar o jardim que cultivava há anos. Precisava podar as roseiras e revolver a terra, já não era sem tempo. Fazia aquele delicado trabalho demonstrando preocupação com o marido que ficara de retornar de madrugada, e o sol já ia alto sem que ele aparecesse.

Os netos chegaram e conseguiram de um espelho. Pareciam se conhecer desde sempre. O viajante dos seus intermináveis sonhos estendeu-lhe a mão. Seu toque fez que a febre chegasse ao ponto de enlouquecê-la. Mas deixou-se ficar assim, mãos dadas, enquanto sentia o corpo aliviar e de novo poder respirar sem agonia.

Os pais se levantaram e receberam o forasteiro. E nada se soube dele, além de que se chamava Feliciano da Cruz e vinha de longe, de uma cidade chamada Mar de Espanha.

Nunca mais foi embora e acabou se casando com Felizarda Esperança. (...)

Numa manhã de inverno, ela sentiu o silêncio do mundo e uma tristeza torturante no peito.

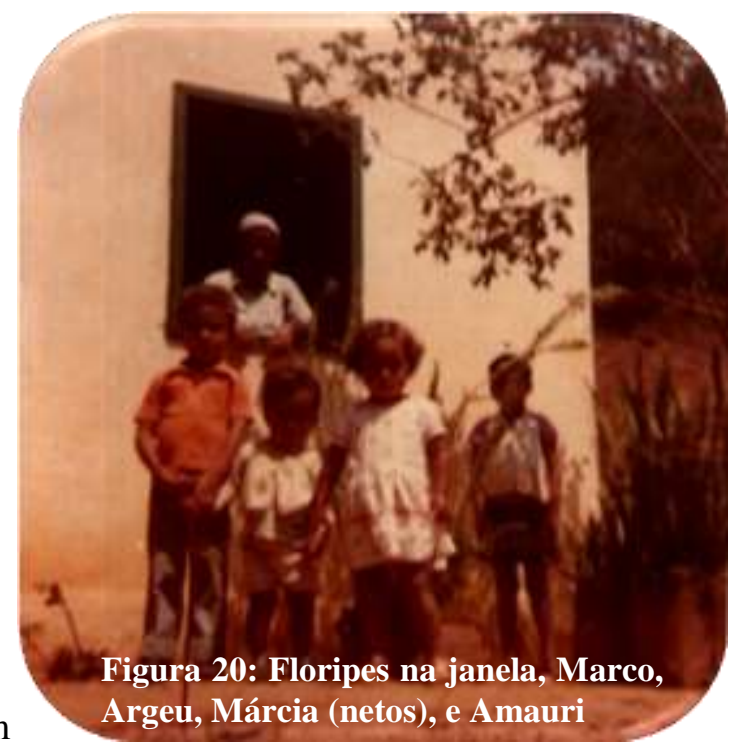


dela um riso largo e a promessa de contar histórias.

De repente seus olhos se voltaram para a estrada, por onde surgia, silencioso, um carro preto com cortinas de franjas amarelas. Parou a uns metros de sua casa. Nunca aparecera um automóvel igual por aqueles lados.

Uma mulher tristonha desceu e caminhou em sua direção e deu a notícia: Feliciano da Cruz deixara seus últimos suspiros num hospital da cidade. Entregaram a ela apenas um corpo pálido e enrijecido.

A notícia logo se espalhou, e em pouco tempo a casa estava cheia de gente. Pela primeira vez presenciaram o desvario daquela mulher. Felizarda Esperança correu em direção à mata chamando por ele. Desceu até o mais fundo de sua dor, no limiar da loucura. Gesticulava seu amor e ódio com a força de uma pantera. Não podia acreditar que tudo terminasse assim, sem aviso. Instantes depois transformou-se em metade de uma mulher. Agora era apenas soluços sentada entre as roseiras. (...) Nos meses seguintes, passava as noites debulhada em lágrimas, que guardava sob os lençóis. Dia após dia tentando enganar a solidão. Até que na véspera de natal daquele mesmo ano, deixou o coração explodir. Uma veia rasgara-lhe o peito jogando-a sobre o chão frio enquanto o suor frio umedecia suas roupas.

O último suspiro livrou-a dos muitos momentos de pura tristeza.

Apesar da saudade deixada como herança, todos entenderam que Felizarda só queria reencontrar o seu amor, do outro lado da vida. (SOUZA, 1998, p. 75-80)

Depois de seis meses no Rio de Janeiro voltei para casa um pouco mais aliviada, e fui dar conta de terminar meus estudos, meu Curso Normal.

\section{2 De professora a escritora, muitos caminhos}

Consegui me formar professora chegando a trabalhar alguns meses na comunidade de Pedra Bonita, no município de Inhapim. Era uma comunidade menor do que a comunidade onde nasci, e eu me lembro do dia em que fizemos a homenagem às mães e alguns choraram, pois eu e Marília, minha companheira de trabalho, éramos as primeiras professoras formadas que chegávamos à comunidade, e preparamos uma festa em que cada um levava um prato de doces ou salgados. Inauguramos a primeira escola da prefeitura com prédio próprio na comunidade, antes disso as aulas eram ministradas por D. Neusa, então professora leiga que trabalhava na tuia ou antigo paiol, de sua casa que abrigava até então a escola onde chegamos a trabalhar por algumas semanas. E era comum naquela época, 1987, os alunos nos levarem de presente verduras, leite, doces, produtos da roça cultivado por seus pais. E nós, professoras, éramos muito respeitadas e queridas, apesar da nossa inexperiência e nossa pouca idade. Mas a vida tem suas artimanhas, e em julho de 1987 eu vim para o Rio de Janeiro em busca de sossego para a alma e de um futuro promissor. Meu primeiro trabalho em terras cariocas 
foi como ajudante de costureira e estofadora, alguns meses depois consegui uma escola para trabalhar como professora, mas depois de um ano e meio a situação financeira ficou insustentável, e acabei deixando a sala de aula indo me empregar como babá na casa de Luana, uruguaia, e Natalie, a filha de um ano e meio; lá teria casa e comida sem ser um estorvo para ninguém; e com o sustento garantido eu poderia repensar e reorganizar a minha vida. Isso era 1989.

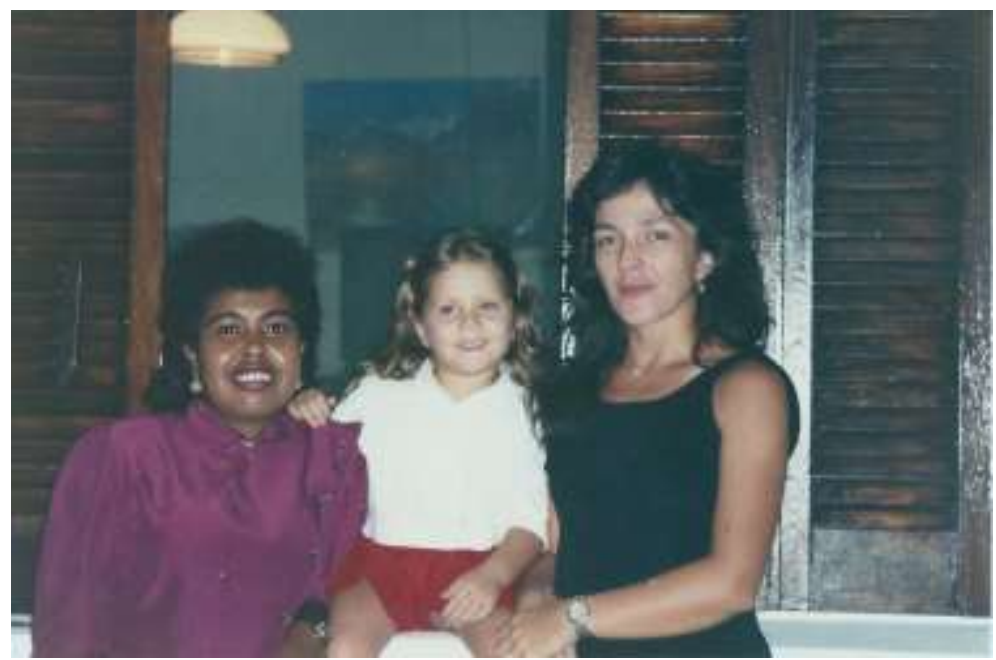

Figura 21: Toquinha, Natalie e Luana

Sair da sala de aula para o quarto de empregada não foi uma decisão fácil, mas no momento não havia outra possível.

Assim que cheguei para trabalhar na casa de Natalie, me foi franqueada a biblioteca, pois sua mãe sabia que eu era professora formada e que tinha deixado o trabalho como professora numa sala de aula na Zona Oeste do Rio de Janeiro para trabalhar como babá. O chamado da necessidade. A desconstrução do espaço de convivência patroa/empregada que eu conhecia foi me dando liberdade para que também a relação empregada/patroa tivesse outro tom, permitisse experimentar mais proximidade, ainda que eu tivesse consciência do meu lugar nessa relação sempre tão delicada entre empregados e empregadores, ainda mais na intimidade do lar. À noite, então, eu lia alguns livros que ia selecionando na estante do escritório, ou escrevia enquanto via novela. Eram desabafos com alguma intenção de poesia ou mesmo em prosa. Comecei a mostrar para Luana os meus escritos e um dia ela me surpreendeu com um recorte de revista, a Vejinha-Rio, com endereço e telefone de uma oficina de literatura ali mesmo no bairro do Leblon. Hesitei, mas me matriculei na oficina, e a partir daquele dia foi que eu comecei a conhecer o que era literatura. Abriu-se para mim um mundo novo. 


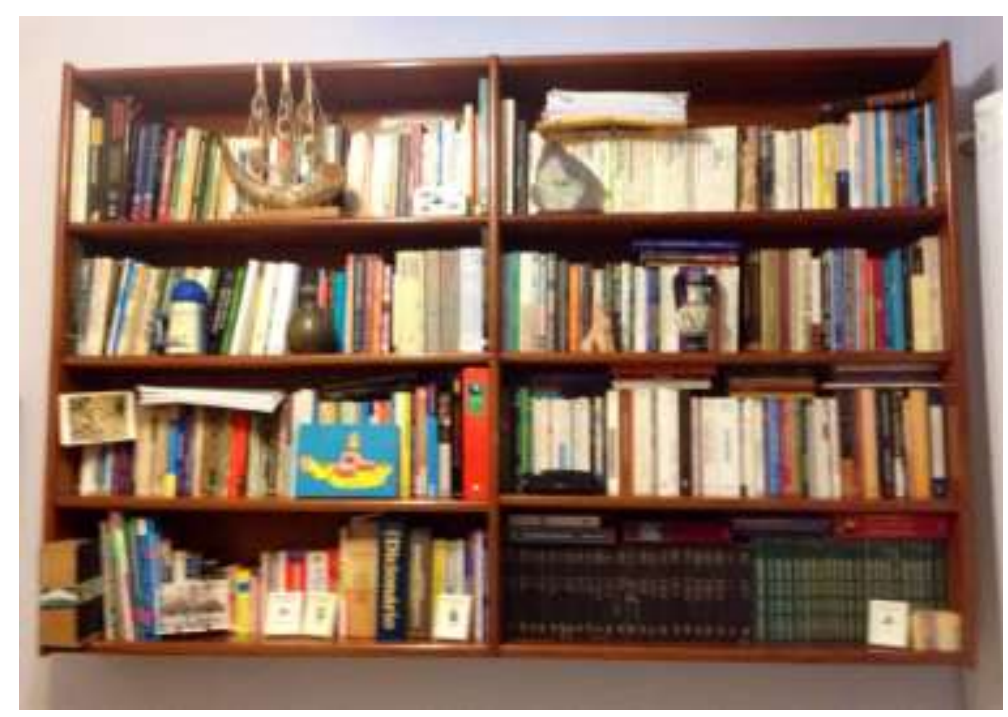

Figura 22: A biblioteca de Luana, a primeira a que tive acesso livre. (Foto de Natalie)

$\mathrm{Na}$ casa dessa família eu fui apresentada a grandes autores, por quem eu fui me apaixonando. Dostoievski, Adélia Prado, Isabel Allende, Guimarães Rosa, Drummond, Gabriel García Márquez, Eduardo Galeano, Clarice Lispector; e à música de Chico Buarque, Caetano, a voz de Maria Bethânia, Marisa Monte, Juan Manuel Serrat, ou seja, fui penetrando esse universo da arte que é janela para outros mundos.

E nas oficinas e eventos culturais que comecei a frequentar eu conhecia a cultura também pelo viés da produção de textos literários, da discussão e entendimento do que é fazer arte. E muitos artistas invadiram meu mundo me alimentando, me fazendo acordar para novas possibilidades. Inscrita na oficina de literatura na Rua Dias Ferreira, no bairro do Leblon-RJ, mesmo antes de participar dos encontros, fui a um sarau literário onde, convidada pelo professor a quem eu conhecia apenas por telefone - eu nem sabia o que era um sarau literário - e depois da insistência dos organizadores, li a história que havia escrito naquela semana especificamente para a ocasião, era a história inspirada na vida simples de uma tia muito querida. Jamais imaginei que aquela história tivesse já um formato publicável, eu soube disso ao final da minha leitura e depois de cessarem os aplausos para o meu texto que, nas palavras do professor Rogério Ferreira, pertencia à categoria do conto. Ali me descobri escritora. Naquela noite tive insônia, li e reli o meu próprio texto inúmeras vezes, e chorei. A emoção era porque, sendo eu mesma na minha ingenuidade, contando a história singela de meu povo, eu era reconhecida e me reconhecia artista da palavra, ou sentia que era o primeiro movimento para vir a sê-lo. O filósofo francês Paul Ricoeur, tratando 
do tema do reconhecimento, me emociona quando valida a minha escolha de ser e agir sempre na simplicidade que me fez nascida para o mundo e toda a sorte que ele me reservava.

Não é em minha identidade autêntica que peço para ser reconhecido? E se, por sorte, me reconhecerem como tal, minha gratidão não será dirigida àqueles que, de uma maneira ou de outra, reconheceram a minha identidade ao me reconhecer? (RICOEUR, 2006, p. 11)

Mas o reconhecimento de fato veio aos poucos, nos meus sucessivos escritos bem recebidos nos saraus mensais que aconteciam em casas de companheiros de oficina pelos bairros da Zona Sul do Rio de Janeiro. Eu já era, ainda que sem refinamentos, o que sonhava ser, mas não tinha consciência. Numa segunda-feira, voltando do meu descanso semanal, encontrei sobre a minha cama, no quarto de empregada, o livro "Cem anos de solidão", com uma linda dedicatória, era um presente de Luana, minha patroa, e este livro seria responsável pela minha nova relação com a leitura e com a escrita. Depois da leitura, que eu não queria que chegasse ao fim, eu me senti autorizada a criar outras histórias, cenários nascidos da minha imaginação. E nunca mais esqueci Macondo, as begônias da matriarca dos Buendía e sua extensa prole de nome sempre igual e sempre diferente. O meu despertar para a literatura se deu no inusitado, por caminhos tortos. Naquele apartamento do Alto Leblon aprendi ainda me comunicar numa segunda língua, o espanhol. Tornei-me escritora, ou melhor, eu me descobri escritora. Eu enxerguei em mim a marca da palavra ouvida cicatrizada em palavra escrita.

O problema da dimensão temporal tanto do si como da própria ação, dimensão que pode ser negligenciada nas análises precedentes: a referência da enunciação ao enunciador e do poder de agir ao agente pareciam poder ser caracterizadas sem que fosse levado em consideração o fato de que o enunciador e agente têm uma história, são sua própria história.

É nessa medida que a identidade pessoal considerada em sua duração, pode ser definida como identidade narrativa, no cruzamento da coerência conferida pelo pôr em intriga com a discordância suscitada pelas peripécias da ação narrada. (...) Ora, a identidade narrativa não elimina essa espécie de identidade. (...) Pode-se atribuir ao caráter esse primeiro tipo de identidade entendendo com isso todos os traços da permanência no tempo, desde a identidade biológica assinada pelo código genético, balizada pelas impressões digitais, a que se acrescentam a fisionomia, a voz, o jeito, passando pelos hábitos estáveis até as marcas acidentais por meio das quais um indivíduo se faz reconhecer, ao modo da grande cicatriz de Ulisses. (RICOEUR, 2006, p. 116-117) 
Minha história singela ganha status de poesia. Publiquei meu primeiro conto “Amor de viajante" (GANG Edições), em 1997, numa coletânea da Oficina de Literatura Cairo Trindade, que funcionava na varanda de seu apartamento no bairro de Copacabana. Encorajada pela façanha, no ano seguinte publiquei, de forma independente, aventureira, "Dicionário de Lembranças" (Ed. Contemporânea), meu primeiro livro.

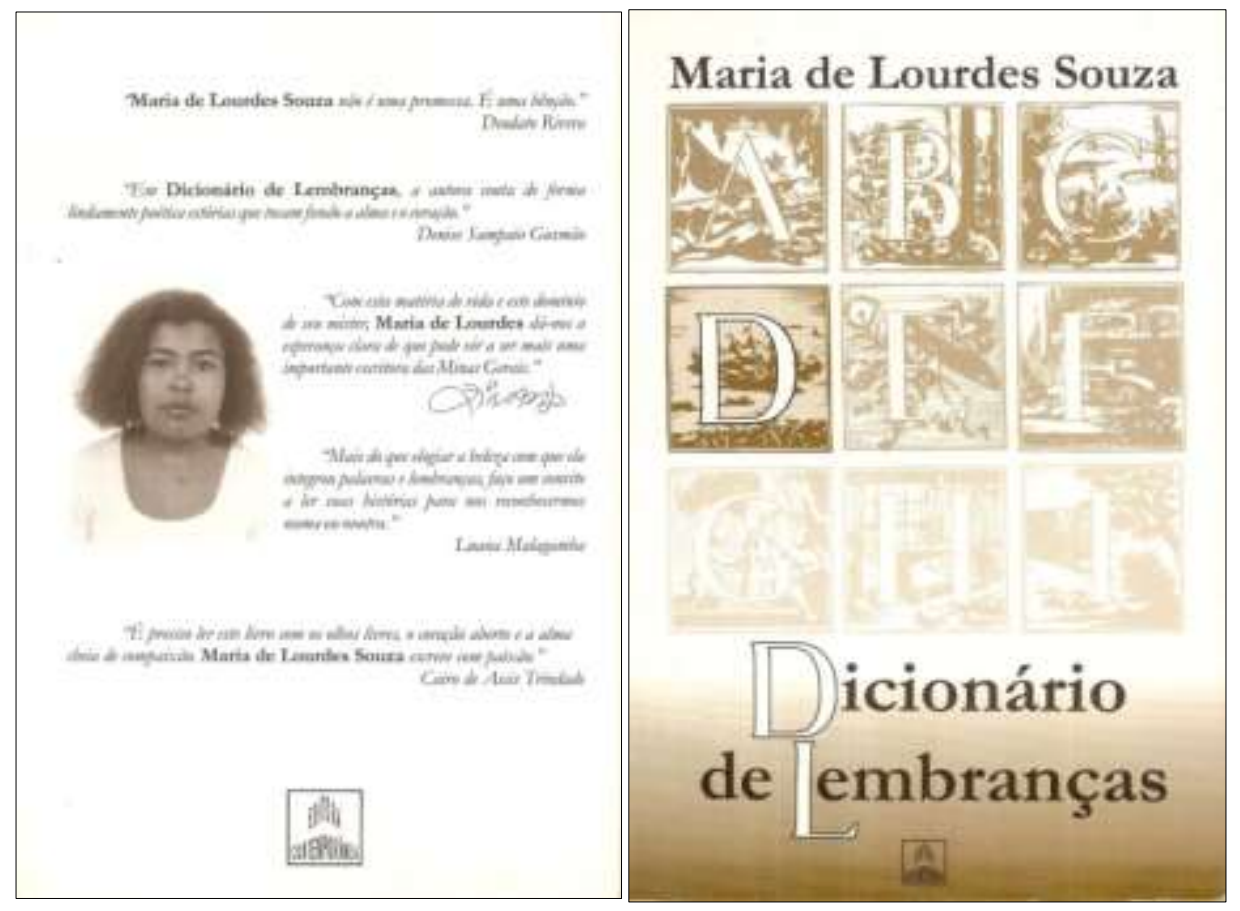

Figura 23: Livro "Dicionário de Lembranças"

Aprendi, pela emoção, pela intuição, que dar atenção aos meus sentimentos enquanto escrevia me dava a dimensão da universalidade da cultura na qual eu estava inserida desde que abri os olhos para o mundo. E como diz Ricoeur, lembrar-se é não esquecer; cumprir uma promessa é não traí-la. (RICOEUR, 2006, p.124). E eu sentia que a minha promessa nascera comigo, que era lembrando de meus antepassados que eu me afirmava. Que pelo caráter genuíno de minhas ações e de minhas palavras eu me tornava alguém com o poder de dizer.

Mas há uma razão que somente a pragmática moderna do discurso sobre pôde evidenciar: ela consiste em que, segundo a famosa formulação do filósofo Austin, falar é "fazer coisas com as palavras". Ao inaugurar a ideia de capacidade pelo poder dizer, conferimos de saída à noção de agir humano a extensão que justifica a caracterização como homem capaz do si que se reconhece em suas capacidades. (RICOEUR, 2006, p.110) 
Construindo minha escrita sobre o solo de minha terra, sobre a história que me constituía, pude perceber-me observadora, sensível às transformações culturais da minha comunidade. E essa relação com a minha terra tornou-se mais visceral quando eu recebi de Tia Fiinha, irmã de minha mãe, a bela lição de felicidade que dali por diante mudaria a minha vida. Foi um diálogo curto, mas de uma verdade e potência que jamais esqueci e que reproduzo de memória.

Toquinha: Tia Fiinha, eu soube que os meninos (os filhos) querem fazer uma outra casa para a senhora. E porque a senhora não deixa fazer a casa nova? Os meninos estão preocupados com a senhora já de idade. Uma casa com banheiro dentro de casa, piso de cimento ou de cerâmica é mais fácil de cuidar.

Tia Fiinha: Ih, bobage. Desde que Catarina (irmã) mudô pra casa nova que num teve mais aligria. Adoeceu e num foi mais aquela muié alegre. Se acabô.

Como? Perguntei a mim mesma. Fiquei muda. Conversamos mais um pouco, esperei que ela fizesse o almoço, almoçamos, e quando dias depois voltei para o Rio de Janeiro eu queria contar aquilo que eu tinha ouvido e que calara qualquer possível argumento que eu pudesse ter para convencê-la do contrário. Tia Fiinha não falou de sua felicidade, falou da falta de felicidade de alguém que ela prezava muito. Foi na infelicidade e na dor da pessoa a quem tanto amava que ela reconhecera a sua própria felicidade, e não queria mudar.

\begin{abstract}
Digamos, pois, que "o bem do homem será uma atividade da alma segundo a virtude, e se houver várias virtudes, segundo a melhor e a mais completa". Com isso é excluída imediatamente a ideia de que a felicidade provém unicamente da graça divina ou da sorte: ela tem sua origem em nós, em nossas atividades. Nisso reside a condição mais primitiva do que nós denominamos reconhecimento de si mesmo. Sua possibilidade radical é a consolidação da aspiração à felicidade em atividades que compõem a tarefa do homem enquanto tal, a tarefa nossa. (RICOEUR, 2006, p. 98)
\end{abstract}

Tia Fiinha, que interrompia seus afazeres, quaisquer que fossem, quando a gente chegava em sua casa e sentava para conversar, tinha sempre comida farta, doces, que ela mesma preparava e enchia as latas que eram guardadas na sua prateleira enfeitada com pano bordado, estava segura de sua felicidade. Trabalhara a vida inteira na lida da casa e da roça e não se imaginava numa casa moderna. Queria para sua vida a alegria, não uma outra casa. Sua felicidade estava entranhada naquela casa de pau trançado e barro, chão de tábua rústica onde criara os filhos e vivera a maior parte de sua vida. A professora e filósofa suiça Jeanne Marie Gagnebin, me instiga a pensar nas palavras de uma sertaneja que tem a 
potência de transformar, que carrega na sua essência a crença no que se é, no que quer e espera da vida.

Ao juntar os rastros/restos que sobram da vida e da história oficiais, poetas, artistas e mesmo historiadores, na visão de Benjamin, não efetuam somente um ritual de protesto. Também cumprem a tarefa silenciosa, anônima, mas imprescindível do narrador autêntico e, mesmo hoje, ainda possível: a tarefa, o trabalho de apokatastasis, esta reunião paciente e completa de todas as almas no Paraíso, mesmo das mais humildes e rejeitadas, segundo a doutrina teológica (julgada herética pela Igreja) de Orígenes, citado em mais de uma passagem por Benjamin.

Hoje não existe mais nenhuma certeza de salvação, ainda menos de Paraíso. No entanto, podemos - e talvez mesmo devamos - continuar a decifrar os rastros e a recolher os restos. (GAGNEBIN, 2006 p. 118)

O depoimento da minha tia era só a opinião de uma sertaneja de pouco saber, que apenas assinava o nome, considerado um resto, coisa de pouco valor na atualidade. Mas o que fazer com os restos preciosos? A casa de pau-a-pique que abrigava a felicidade daquela mulher também era, prestes a ser demolida, um resto, mas que deixara um rastro, uma conversa-conselho, ainda que não tenha tido intencionalmente este caráter, ao fim a e ao cabo, eu recebera naquele momento, um ensinamento, um alerta de cuidado com o desejo de prosperidade, de progresso. Eu recebera um anúncio de um tesouro que jazia sob o solo do córrego dos Januários, minha terra. E então sucedeu que eu tive que escavar, pois era um recado do tempo, urgente, como uma conversa entre pai e filhos no leito de morte, ao modo do pai no texto "Experiência e pobreza", de Walter Benjamin.

Em nossos livros de leitura havia a parábola de um velho que no momento da morte revela a seus filhos a existência de um tesouro enterrado em seus vinhedos. Os filhos cavam, mas não descobrem qualquer vestígio do tesouro. Com a chegada do outono, as vinhas produzem mais que qualquer outra na região. Só então compreenderam que o pai lhes havia transmitido uma certa experiência: a felicidade não está no ouro, mas no trabalho. (BENJAMIN, 1985, p. 114)

As palavras de Tia Fiinha viraram literatura, arte. Benjamin e Tia Fiinha conversam, filosofam e aconselham. Se entendem. Filosofias e conselhos se entrelaçam no emaranhado da confusa temporalidade e das peripécias que permitem que suas ideias se encontrem e se complementem, e/ou fortaleçam novos pensares. O que fora dito despretensiosamente por Tia Fiinha fora lapidado e dado a conhecer, e é compreendido como filosofia de vida que inspira; o que escrevera Benjamin ganha corpo nas palavras da sertaneja que nunca pensou em 
filosofia, como se dissessem, cada um com suas palavras: temos que aprender com o passado, com as experiências dos outros e com as nossas.

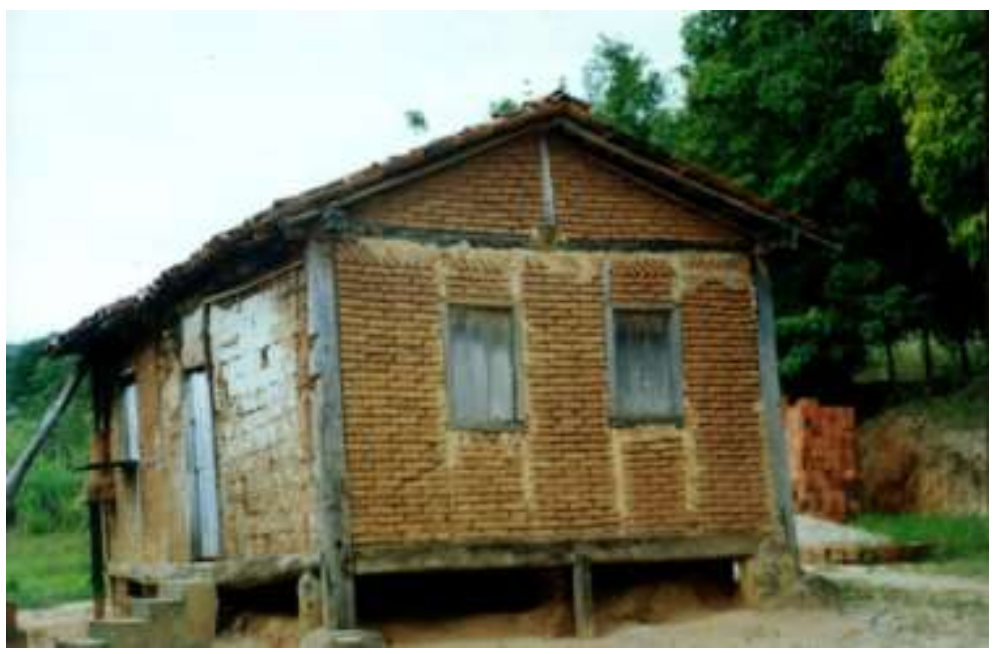

Figura 24: Casa da Tia Fiinha (Foto de Denise Gusmão)

Sobre essa casa eu escrevo, alguns anos depois, o conto Lembranças de tapera, ainda inédito.

Os companheiros da moça estranharam seu silêncio, há tempos não a viam assim. Mas ninguém sabia que a tristeza dela era por conta de uma tapera cheia de história num lugar longe dali que mais dia menos dia ia virar poeira misturada com saudade. A tapera para ela era um lugar onde se podia guardar sonhos. Enquanto os sonhos estivessem ali, ninguém bulia. Sabia que era obra do tempo, da própria natureza, mas ainda assim uma dor grande a consumia na peleja por achar um jeito de mudar tal destino. Tinha jeito não. E isso a fazia ter vontade de chorar por mais que o moço que ela tanto gostava cantasse a noite inteira. (...)

Mas a verdade é que o tempo todo ficava entre a tapera e a palavra, entre a tapera e o sentimento, entre a antiga tapera e o sonho. E quem diria que um monte de pau trançado, amarrado com cipó coberto de barro sem pintura nem nada, só tingido de barro branco branco branco causaria tamanho destempero. (...) A tapera já era um personagem porque guardava uma história, um enredo tecido de tempo, de sabores doces guardados em potes sobre prateleiras singelamente enfeitadas com panos bordados a mão, de panelas aquecidas por labaredas tremulantes ou braseiros que ficavam lá cumprindo destino. E uma mulher sentada num banco fazendo seu cigarro de palha, guardando memórias nas frestas de pau antigo por onde entrava um vento frio no mês de maio, junto com o perfume das roseiras que ela tanto apreciava, e que nas noites de lua cheia recheavam os olhos da gente de uma beleza sem igual. (Trecho do conto de minha autoria, ainda inédito, "Lembrança de tapera") 


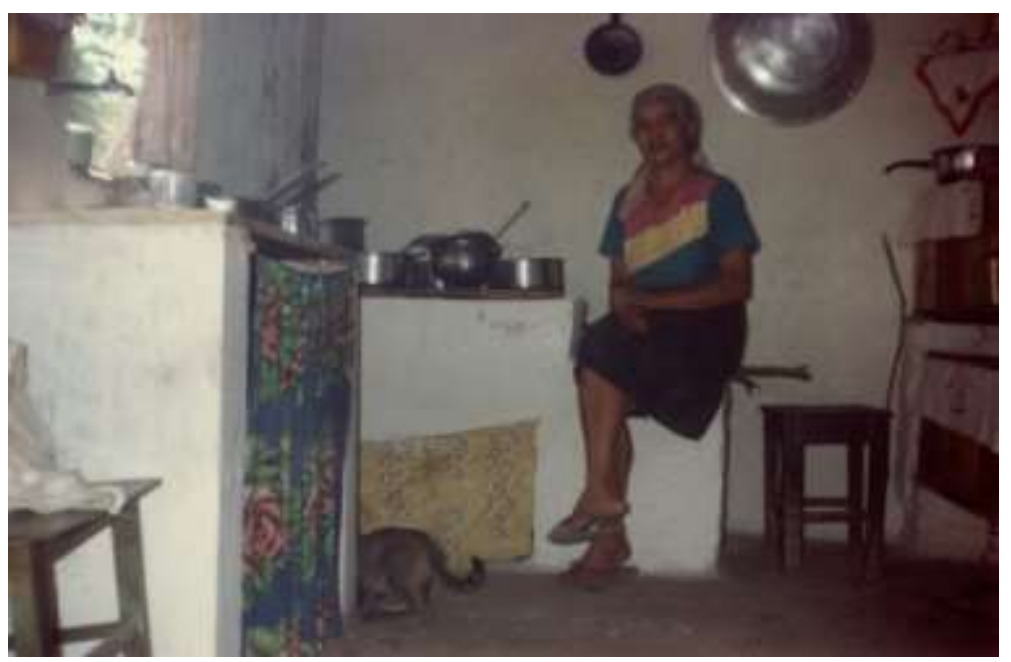

Figura 25: Tia Fiinha

Reconheci na simplicidade dela que eu estava diante de algo muito especial que mais tarde se transformaria no conto Felicidades, um passeio à beira-mar, que eu lera naquele sarau na Zona Sul do Rio de Janeiro e que fecha meu "Dicionário de Lembranças". Na reprodução de parte do diálogo do conto, a poesia na simplicidade de D. Felícia.

-Quem te deu todas essas coisas?

-Foi Deus, Nosso Sinhô.

-A senhora sabe muita coisa?

-Num sei nada, minha menina! O que sei aprindi na vida, com o tempo.

-A senhora sabe ler?

Sei assiná meu nome.

-Por que a senhora não pede pra Seu Luiz fazer uma casa nova? Essa tá muito velhinha. Parece que quer cair.

-Nem pensá, minha fia. Eu tenho medo de dismanchá essa tapera que foi de minha vó, e minha alegria morrê com ela. Minha irmã dismanchô a casa véia, feis uma casa nova e eu acho, cá pra mim, que a felicidade dela morreu de tristeza.

-Mas, D. Felícia, felicidade não morre!

-Minina Juliana, a felicidade pra mim é que nem um passarinho. Se ela posar na sua janela, ocê dé de comê pra ela, tomá conta dela, passado uns tempo, tá que nem um vivero. Uma felicidade chama a outra e vai assim toda vida. Mas se ocê num cuidá, ela vem um dia, faia dois. Vem notro dia e faia treis. Até que cansa e vai simbora. Eu sempre fui feliz aqui, com as coisa que tenho. Eu fiz o meu vivero. Vorta-e-meia aparece um fiotinho novo da tal felicidade. Quando ocê crescê pode tê um que nem o meu. É só tê carinho e amô no coração. (...) (SOUZA, 1998, p. 87-89)

Aquela lição transformou-se em literatura e me acompanha desde então.

Felicidade passou a ter sentido de realidade, não de utopia. Depois de eu escrever essa história desencadeou-se um processo bastante inusitado, pois, com aquele 
conto fui aceita no mundo dos escritores e, conheci um grupo de pessoas que viram beleza em meus textos, e tornaram-se grandes amigos.

\section{3 \\ Volta ao Córrego em três dias: uma aventura em busca da memória}

No ano 2000 ganhei de Deborah Alexander um pequeno grande livro chamado "O dom da história", da psicóloga americana Clarissa Pinkola Estés, que fala da importância da contação de histórias, das reuniões familiares onde se conta histórias, da transmissão de conhecimento entre gerações. Quando terminei de ler o livro o abracei e chorei.

Uma coleção de histórias culturais, e especialmente de histórias de família, é considerada tão necessária para uma vida longa e saudável quanto uma alimentação razoável, trabalho e relacionamentos razoáveis. A vida de um guardião de histórias é uma combinação de pesquisador, curandeiro, especialista em linguagem simbólica, narrador de histórias, inspirador, interlocutor de Deus e viajante do tempo (ESTÈS, 1998, p.09).

Fiquei tão tocada pelo que acabara de ler que liguei para Deborah para agradecer, e para Denise Gusmão para contar minhas ideias. Contei que iria, tão logo fosse possível, para a minha terra registrar em vídeo e áudio as histórias da minha gente, sem mesmo saber como, pois não tinha os equipamentos necessários. Foi uma vontade que desde aquele momento passou a ser necessidade. E era urgente, pois desde que a luz elétrica chegara no Córrego dos Januários, em 1984, muito da nossa cultura começou a desaparecer. A chegada da televisão foi um divisor de águas. As pessoas foram se distanciando, os valores culturais foram sendo renovados sem muita consciência do progresso. Cada vez que eu voltava lá sentia-me mais distante dos meus e de mim mesma. Algo muito estranho e ruim estava acontecendo. Era preciso fazer alguma coisa, ainda que fosse apenas um registro particular da história da minha família. Era urgente registrar, tornar conhecida, pensar sobre a história de vida da minha família, que era também a história de muitos, resultado de palavras alheias das quais nos apropriávamos, como diz o filósofo russo Mikhail Bakhtin. Dessas palavras alheias fazem parte contos tradicionais, histórias de vida, nosso dia-a-dia. As nossas histórias. 
A notícia do meu desejo verbalizado foi se espalhando entre os amigos e fiquei muito surpresa quando uma semana depois eu soube que um grupo de pessoas muito queridas desejava me acompanhar nessa aventura. Queriam muito conhecer a casa onde tinha vivido até bem pouco tempo a pessoa que inspirou a criação da personagem $D$. Felícia, de que tanto gostavam.

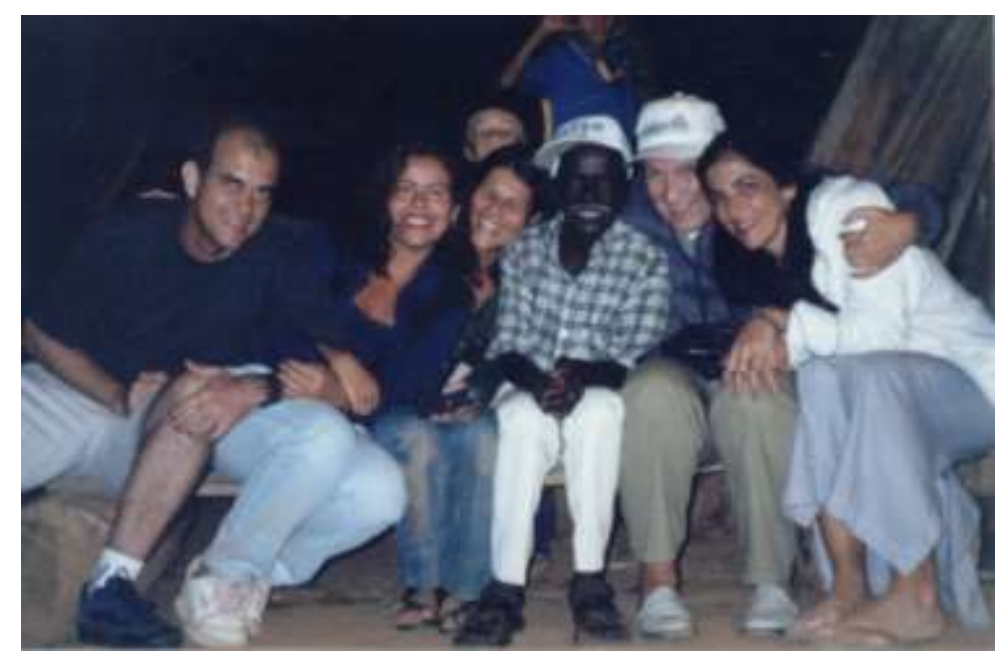

Figura 26: Brenno, Denise, Deborah, Seu Agenor, Deodato e Cláudia

O resultado foi um lindo encontro entre meus amigos e a minha gente. Três dias de fornada de broas, forró e conversa regada a boa comida e boa prosa. E eu ia contando a minha história, apresentando о mеи lugar, auxiliada pelos amigos aventureiros e tudo sendo registrado pelo cinegrafista Brenno de Britto, vindo de Porto Alegre especialmente para o evento, e por Deborah Alexander, responsável pelo making off.

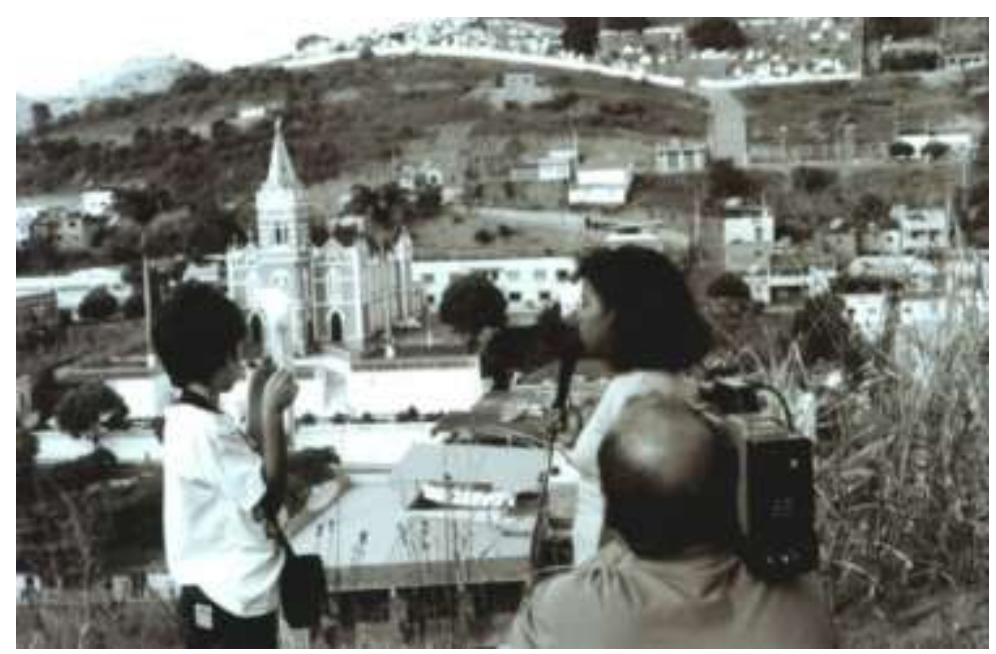

Figura 27: Juca segurando a dália, Maria de Lourdes narrando a cidade e Brenno filmando (Foto de Denise Gusmão) 
Durante esse memorável encontro Denise Sampaio Gusmão ${ }^{7}$ percebeu a riqueza do que havia ali e que estava ameaçada de desaparecer, e iniciou então um projeto do qual me orgulho muito de ter participado. Denise Gusmão fez da tarefa de escavar o solo dos Januários e registrar manifestações culturais da minha comunidade seu projeto de pesquisa de mestrado, e posteriormente de doutorado, no Departamento de Psicologia da PUC-Rio, no GIPS (Grupo Interdisciplinar de Pesquisa da Subjetividade), sob a orientação da professora Solange Jobim e Souza. Foram sete anos de um trabalho regido pela delicadeza e pela dedicação da pesquisadora. E como legado para a minha gente Denise deixaria, além de muita reflexão sobre o que vivíamos, o material produzido durante sua pesquisa transformado no acervo de contos e imagens que hoje compõe a Casa de Memória e Cultura do Córrego dos Januários.

E nesse lidar com a palavra, fosse pela leitura ou pela escrita, fui me apossando de valores, de respeito por minha própria história, e do encanto de conhecer outros universos.

Esse caráter perpetuador da escrita, o papel desvelador da leitura e o exercício de um e de outro deveriam ser melhor compreendidos, melhor exercitados, pois a grande maioria da população aprende que livro é artigo de luxo e de pouca serventia. O papel da arte e o tempo dedicado a ela, seja na produção ou na apreciação, o mais das vezes é tido como tempo perdido. Mas eu perdi o medo de frequentar livrarias, me transformei numa compradora de livros e, assim fui perdendo também o medo ou a vergonha de ir ao teatro, de entrar nos bons restaurantes, de falar o que pensava. Eu ganhava autonomia. Foi um aprendizado a partir dos encontros, da partilha de saberes, da generosidade de muitos. E desde então fui me dando conta de que

É preciso fazer uma análise profunda e aguda da palavra como signo social para compreender seu funcionamento como instrumento da consciência. É devido a esse papel excepcional de instrumento da consciência que a palavra funciona como elemento essencial que acompanha toda criação ideológica, seja ela qual for. A palavra acompanha e comenta todo ato ideológico. (VOLOSHINOV; BAKHTIN, 1979, p. 23)

\footnotetext{
${ }^{7}$ Denise Sampaio Gusmão é Psicóloga. Especialista em Educação Infantil. Mestre e Doutora em Psicologia pela PUC-RJ. Membro do corpo docente do curso de especialização- Educação Infantil: Perspectivas de Trabalho em Creches e Pré-Escolas da PUC-RJ. Membro do Núcleo Interdisciplinar de Memória, Subjetividade e Cultura- NIMESC, que integra o Departamento de Psicologia e Artes \& Design da PUC-Rio. Consultora e Pesquisadora no campo da memória social e coletiva tendo como foco a interface entre psicologia, educação, fotografia e cultura.
} 
Esse meu aprendizado foi se dando à medida que eu tomava consciência tanto do valor da minha cultura quanto de que eu começava a assumir um papel importante na comunidade, e que meu instrumento de ação era, por excelência, a palavra, a minha atividade de escritora. Eu, desde muito cedo, ainda que inconscientemente, sabia da força da palavra, e da força das histórias de minha gente. E a vida foi me permitindo reconhecer o que vinha junto com o conhecimento que eu adquiria, e a minha tomada de consciência impulsionava a minha ação, pois, ao longo da vida venho tornando próprias muitas palavras alheias. Sou fruto de contos, de causos, de lições ouvidas e das quais fui e vou me apossando para tecer minhas histórias. E mesclando a minha palavra e a do outro, tendo a interpretação como transformação do alheio no "meu alheio" (BAKHTIN, 2003), vou construindo meu discurso. E essa somatória de coisas aprendidas, de apropriações do alheio, vai me construindo, construindo a minha comunidade, as minhas comunidades. Pois, em acordo com Bakhtin, sem o outro não há discurso, sem o outro não existe $e u$, pois é no encontro que se dá o reconhecimento do eu como esse ser apartado pela diferença. Na estranheza do outro é que me vejo e tenho referência para poder me ver, não no espelho. É no excedente da visão daquele que não sou eu que são criados os contornos de mim, que delimito meu espaço, pois eu sou a minha pessoa e o que me cerca. E isso me constitui. E as ideias de Mikhail Bakhtin, entre elas ainda o princípio da exotopia, a possibilidade e a necessidade do distanciamento necessário para olhar de fora mesmo sendo de dentro, para perceber a riqueza das pequenas e singelas expressões da cultura, se bem as compreendi, me apoiam para conceber a ideia de conduzir os caminhos de uma casa que nasceu para ser e tem sido abrigo para a cultura de uma comunidade e mantém um grupo de leitores que, com todas as dificuldades, cria, vai além dos próprios limites.

O excedente da minha visão é o broto em que repousa a forma e de onde ela desabrocha como uma flor. Mas para que esse broto efetivamente desabroche na flor na forma concludente, urge que o excedente da minha visão complete o horizonte do outro indivíduo completado sem perder a originalidade deste. Eu devo entrar em empatia com esse outro indivíduo, ver axiologicamente o mundo de dentro dele tal qual ele o vê, colocar-me no lugar dele e, depois de ter retornado ao meu lugar, completar o horizonte dele com o excedente da minha visão que desse meu lugar se descortina fora dele, convertê-lo, criar para ele um horizonte concludente a partir desse excedente da minha visão, do meu conhecimento, da minha vontade e do meu sentimento. (BAKHTIN, 2003, p. 23) 
E é na empatia com o outro que nos convertemos ambos em seres completos, não no sentido de acabado, de perfeição, mas de inteireza como pessoa. E dessa contemplação do outro é que nasce a minha singularidade, que se abre o espaço para eu existir com toda a minha complexidade, sem ser mais nem menos, mas ser $E u$. E esse $E u$ tem responsabilidades. Na relação de alteridade me construo como sujeito. E é no intercâmbio de conhecimentos, de saberes que vou me tornando parte, tecendo redes, e pelo caminho espalho notícias de meus aprendizados. Conhecendo e dando a conhecer. E pelo Jornal Oficina de Ideias-de Inhapim, junto com Denise, escrevo sobre o que vamos descobrindo.

\section{FAMÍLIA RIBEIRO E JANUÁRIO SÃO PIONEIRAS NO MUNICÍPIO DE INHAPIM}

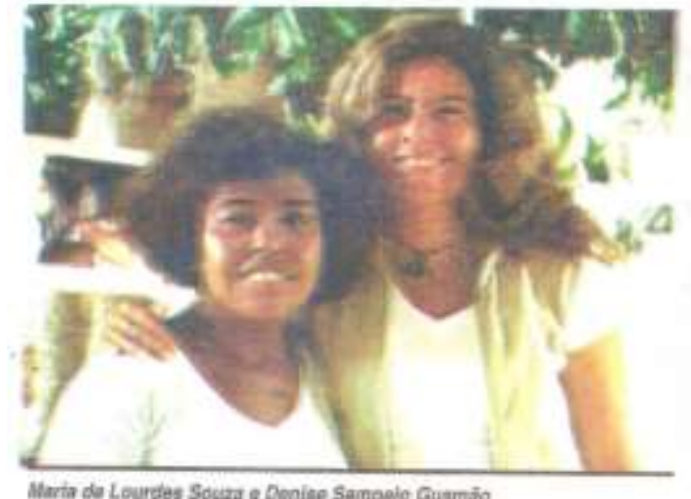

Mavia do Lourdes Socsa a omice sampaic Guama

Desde de criança ouço dizer que sou descendente ds cidade de Inhapim, mas sempre me soou como uma coisa muito distante o nem dava real portancia. Ha alguns anos. quando come cei a descobrir o pader da palavra e nasceu err mim o de sejo de escre ver historias, gurgiu tambèn a necessidade de conhecer minha própria historia.

Percorri muttos caminhos

et6 chegar ao Rio de Jane ro, onde conheci pessoas que se aliaram a esse meu desejo e desde o inicio de 2002, minha amiga Denise Sampaio Gusman de senvolve. no Corrego dos Januârios, seu Projeto de Mestrado em psicologia Contos e Imagens das Roças de Minas" pela PUC/RI, sob orientaç̄o da
Professora Solange Joblim e Souza.

Durante os altimos dois anos temos feito oficinas euniōes com a comunita de e trabalhado nas esco. las do Corrego com o apolo da Prefeitura através da Se cretaria Mun cipal de Edu caçã̃o. Tamrbêm conta mos com a dH. rectồo da E. E Dr. Gulihermino de Oliveira que nos abric as portas. Desde en tho através do reglistro de fotografie, da historia oral colhida em entrevistas e em conver sas com os mais veitios, jovens e crianças, a nos sa histôria estâ sendo re cuperada. Hole um Centro Cultural esta sendo criado unto com a comunidade. onde ja comeca a funcio blioteca. nar nossa recèm-criada bi-
Eu, Maria de Lourdes Souza, participo na realiza căo do projeto come o fio condutor, quem faz a porn te entre a pesquisadora $a$ a comunidade, jáa que esse projeto tem sua semente num antigo desejo meu de cespatar a história cultural do meu lugar, da minha terra, a identidade da mihith gente.

A familia Rioeiro e Janu. ario tern a marca da bra vura, da cultura tipicamen te interiorana que estava ameaçade de se perder. mas esse destino esta mudando.

Como descentos de to aquim Josê Ribeiro, pto neiro/fundador de Inha. pim, है com ortulho que eu, a comunidade dos Ja. nuários e amigos do Rio de laneiro, estamos se guindo pistas que nos ie vam ào encontro de uma rica historia que reúne, entre outras coisas, forca tề e esperança.

Muitas outras famtlies chogaram a inhapim se Juntando a nos, tazendo da cidede o lugar ideal para crisrem seus filhos a fazendo com que ala, cravada entre essas enigmáticas montanhas de Minas Gerais, encontrasse seu caminho e prosperasse.

Somos um povo forte e sonhador e hoje podemos dizer, ainda timidamente. quo estamos nos reconhe. cendo, nos re-inserindo no cenario inhapinhense.

Marfa de Louriefes Souza

Figura 28: Matéria publicada no jornal Oficina de Ideias, de Inhapim 
E no que vou dando a conhecer, vou também compreendendo que o processo de aprendizagem é longo e vou buscando aproximar os teóricos do meu universo e vice-versa. E levo Mikhail Bakhtin lá pros interiores de Minas e lhe faço um cordel

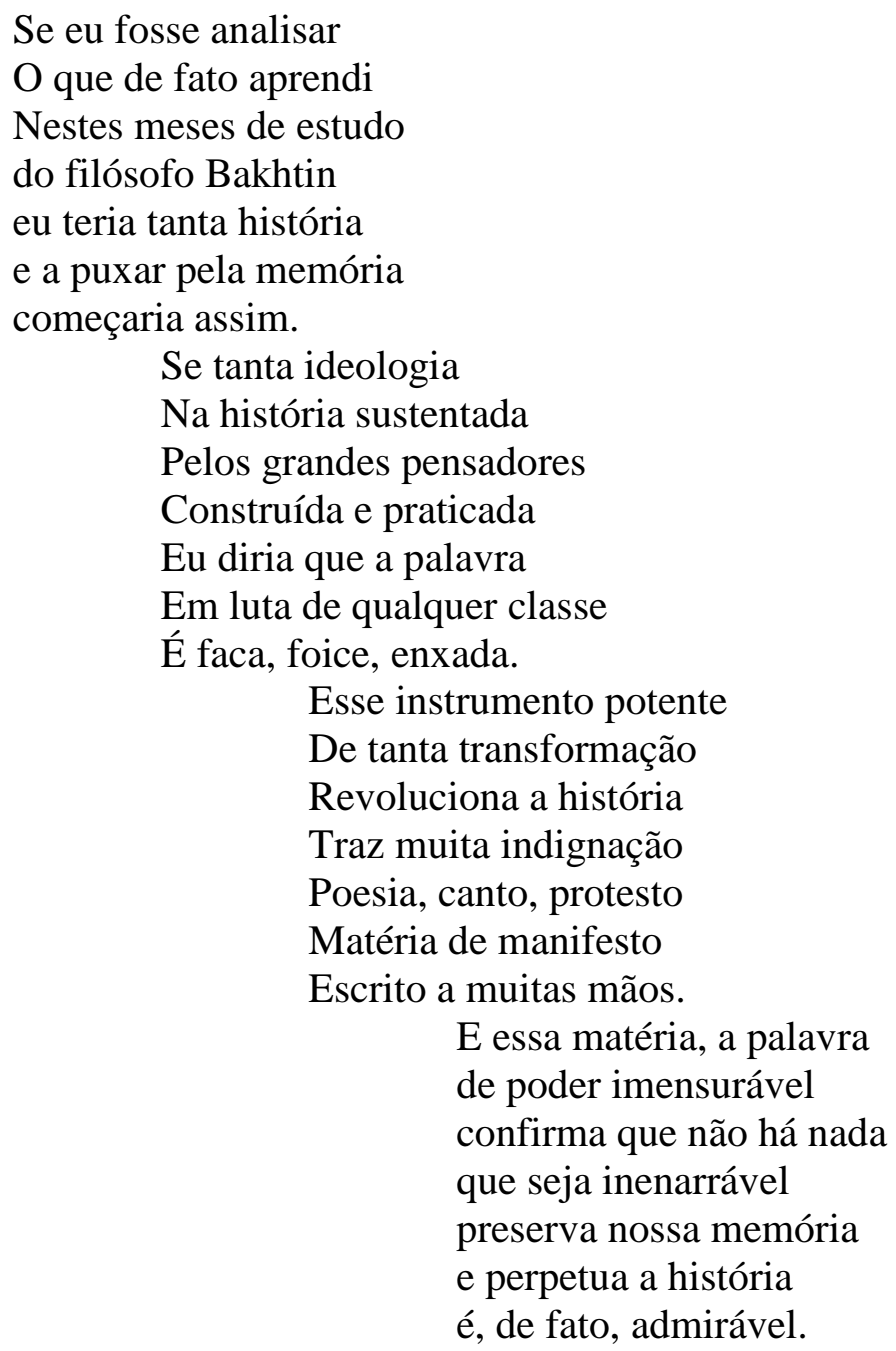

Homens de grandes saberes

E outros no anonimato

De muitos antigamentes

E os atualizados

Sentem-se muito ofendidos

De fato desmerecidos se da honra duvidados.

Sou um homem de palavra

É comum assim dizer

Se a de rei não volta atrás

Não vá me desmerecer

E a dizer: preto no branco

vale a honra no entanto

não vá ninguém se ofender. 
E nessa relação de alteridade, o sujeito que fui aprendendo a ser, que foi se construindo desses encontros com tantos outros, se afirmava. Os medos eram menores, as expectativas, maiores. Meu mundo se alargava, e eu precisava saber me mover nele, ou, precisava me mover mesmo com as inseguranças de lidar com coisas novas. O que se desenhava como história era a potência da palavra transformação.

Dentre os muitos outros com quem fui me encontrando está a Universidade, essa instituição formada de homens.

A transformação vinha da consciência que eu ia adquirindo junto com todo um povoado. As minhas conquistas se davam porque toda uma história comunitária, de convívio familiar, que estava em vias de esquecimento, passava pelo mesmo processo de autoconhecimento. O que nos fazia fortes como comunidade estava se fragilizando, e o processo de escavação da memória empreendido por Denise nos alertava a todos para o reconhecimento do que éramos, do que representávamos como grupo, como sociedade.

\section{4 \\ Maria de Lourdes - a Toquinha, e a Universidade}

Entrar para a Universidade foi um acontecimento. Depois de vinte anos fora da escola e do sistema educacional como um todo, me parecia pouco provável conseguir voltar a estudar. Mas era uma necessidade tentar, pois desde o início do trabalho com Denise Gusmão acendeu a luz da urgência em retomar os estudos. Para me familiarizar novamente com o que então se estudava, me matriculei no curso Vetor Pré-vestibular Comunitário. Surpreendentemente me saí bem, passando no vestibular para as duas faculdades para as quais me inscrevi, UERJ e PUC-Rio. Quando recebi a carta comunicando a minha aprovação para a PUC-Rio eu quase não acreditei, havia sido aprovada com a nota do ENEM (Exame Nacional do Ensino Médio) em $13^{\circ}$ lugar. Contei pra todo mundo a minha conquista e era hora então de rezar para conseguir a bolsa de estudos. Fiz minha inscrição no PROUNI (Programa Universidade para todos), e fui selecionada. Decidi pela PUC-Rio porque ficava perto do trabalho e me facilitaria a vida, sem dizer que era meu sonho frequentá-la como aluna. Sonho realizado, agora era dar conta de tudo. 
Ao me matricular na faculdade, eu fiquei muito ansiosa para o início das aulas, na primeira semana eu passei mal, tive vertigem, acho que era realização demais. Na segunda semana eu já havia me ambientado, senti que era capaz de me adequar àquele mundo tão de meninas recém-saídas do Ensino Médio, eu não era uma estranha. Gostei daquele universo. Ao final do primeiro semestre percebi que não era possível conciliar os estudos com o trabalho de empregada doméstica, o horário das minhas tarefas competiam com o horário das aulas e eu tive então que reorganizar a minha vida. Procurar outra moradia, outro meio de me sustentar e me manter na faculdade, me readaptar, e eu fui levando do jeito que dava. Entre casa de amigos e pensionatos, ajeitava-me.

Guardo muitas boas lembranças do tempo que trabalhei ali no Alto Leblon, e no processo de escrita dessa história, solicitando algumas fotografias à Natalie, hoje com 26 anos, numa conversa via facebook, ela faz algumas declarações espontâneas relacionadas à sua infância, que me emocionaram. Parecia que eu a via pequena, nós duas inventando árvores de natal com galhos secos, cardápios inusitados, criando laços de afeto.

\section{SToquinha}

Estou escrevendo justamente sobre esse momento que vivi na sua casa. Dá uma saudade de vcs...

\section{DIt Natalie}

Olhando as fotos senti a mesma coisa agradeço muito por minha infância ter tido muita criatividade do seu lado!

Tenho muitas lembranças bonitas.

Nas historias, nos artesanatos, nas comidas (que muitas vezes tb eram artesanatos)

$\mathrm{Eu}$ me achava o máximo porque você gostava de ler pra mim o que vc tinha escrito!

Lembro da rosa negra.

E da rosa frita! Lembra?

\section{Wroquinha}

fala sério...

mas a rosa era assada (pétalas de rosa açucaradas e assadas) ...

\section{d. Natalie}

Serio?! Lembro de ser tão crocante.

\section{SToquinha}

Não imaginava que você tivesse essas lembranças...

Muitas loucuras, né? E sua mãe incentivava... 


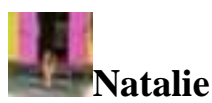

Você pode achar até engraçado

Mas lembrar do cheiro do seu bolo me fez soltar umas lágrimas.

Mas acho que toda infância boa merece ter cheiro de algum bolo.

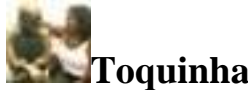

Que bom que o cheiro de bolo da sua infância é o cheiro do bolo que eu fazia!

Mas os tempos eram outros e a necessidade mais uma vez me fez agir e eu procurei a prof. Ana Paula Kiffer, então minha professora da disciplina Formação do Leitor, meu primeiro semestre na faculdade. Dei meu livro de presente a ela, e falei da minha situação pedindo que me ajudasse a conseguir trabalho, fosse o que fosse, mas que, se possível, fosse em algum lugar que tivesse a ver com livros. Alguns dias depois, com sua orientação, eu me tornava estagiária da Cátedra UNESCO de Leitura PUC-Rio. Não sei se sorte ou destino eu fui trabalhar na Casa verde do bosque, ainda em obras.

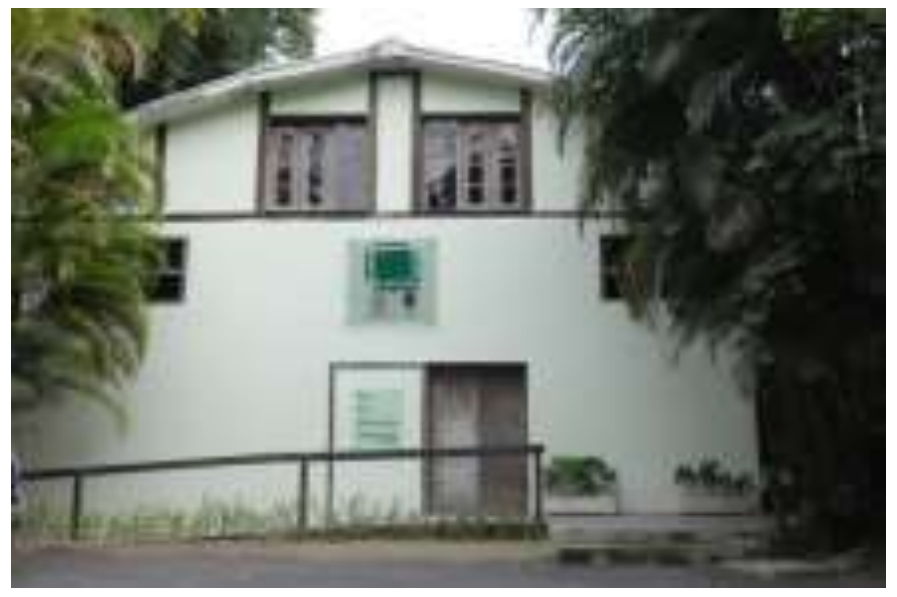

Figura 29: Cátedra UNESCO de Leitura PUC-Rio

$\mathrm{Na}$ Cátedra eu entrei em contato com a literatura infantil e juvenil desde os contos tradicionais de matriz oral, berço de minhas inspirações, aos sucessos de venda e de crítica, se se pode dizer assim, e com acesso à teoria sobre o assunto. Com a doação de seu acervo particular de literatura infantil e juvenil à PUC-Rio, Eliana Yunes, professora do Departamento de Letras, criou o espaço de excelência para pesquisa na área, a Cátedra UNESCO de Leitura PUC-Rio, hoje Instituto Interdisciplinar de Leitura da PUC-Rio. A profusão de obras dos mais variados autores e assuntos, de diversas épocas, nacionais e internacionais, me deu a dimensão do mundo da literatura direcionado aos leitores em formação, ampliou 
meus conhecimentos acerca deste campo da literatura. E eu dia-a-dia me certificava de que era nesta seara que eu me sentia confortável, que era entre os livros da BLIJ (Biblioteca de Literatura Infantil e Juvenil) que eu ia mais longe nas minhas viagens pelos campos da infância e nos projetos de futuro. E eu queria levar o que aprendia para meus companheiros de trabalho lá no Córrego dos Januários. Algumas vezes, nas minhas viagens a Inhapim, eu levava livros da Cátedra para visitar o Clubinho de Leitura. Tomava emprestado para ler e levava na viagem. Enquanto lá estive sorvi cada gota de aprendizado possível.

Depois de quatro anos lidando nesse universo dos livros diariamente e me formando como formadora de leitores, aprendendo sobre práticas leitoras, fui convidada a usar meus conhecimentos criando o projeto de sala de leitura para a Associação Beneficente São Martinho, onde tudo era aprendizado. A organização do espaço, a parceria com David e Bárbara, casal de americanos voluntários, missionários da igreja anglicana, que moravam na instituição e trabalhavam com as artes plásticas junto às crianças, e que decoraram toda a sala de leitura, o desafio de trabalhar com crianças e adolescentes em situação de risco social, numa área de conflitos constantes. E passando pela seleção de acervo, interação com a comunidade, a tentativa de diversificação das atividades com a literatura, tudo contribuía para que eu me afirmasse como profissional na área das letras, da lida com a literatura, principalmente com crianças e adolescentes.

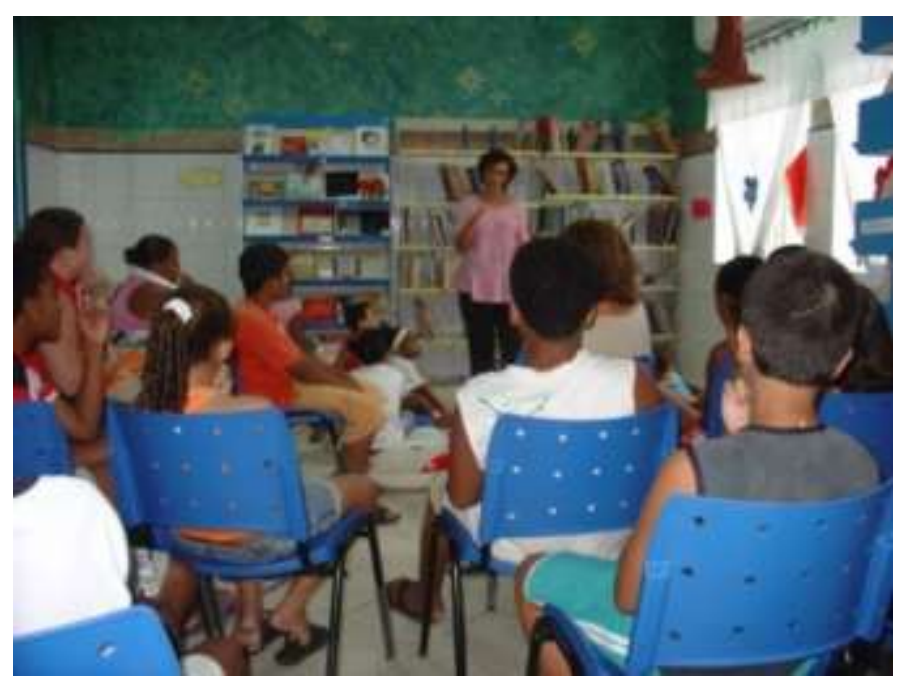

Figura 30: Contação de histórias na Sala de Leitura Educagente, por Rute Casoy

Por dois anos cuidei para que fosse criado e mantido o projeto Sala de Leitura Educagente. Quando vi a sala pronta, as crianças e os adolescentes 
desfrutando, eu me dei conta de quanto era longo o meu caminho percorrido até aquele momento, e que meu repertório literário se diversificava, e eu me profissionalizava aprendendo, na prática, a criar espaços de encontro com o livro.

A vida acadêmica era um encontro diário com o novo, um intenso despertar para o mundo do conhecimento. A lida diária na Cátedra de Leitura, as aulas de Sonia Kramer, professora do Departamento de Educação PUC-Rio, além de toda a minha formação no Curso de Letras, são base para o que hoje penso e faço com mais desenvoltura nesse universo da leitura para crianças e adolescentes na escola, nas bibliotecas e salas de leitura, e da cultura como um todo. Olho para uma estante de livros e me sinto capaz de lidar com eles emocional e profissionalmente. Sei a carga de conhecimentos que eles guardam e sei também que por onde transito hoje é ainda o início do caminho.

Aquela Universidade tão Zona Sul carioca, além de nutrir teórica e literariamente a minha necessidade de conhecimento, me aproximava de pensadores que me ensinavam a entender o mundo como ele é, seus meandros, um bocado da filosofia e da sociologia entre tantas outras ciências que iam me aclarando as ideias, entendendo quem dizia o que e as implicações destes pensamentos na engrenagem da história. E conhecer o pensamento destes grandes homens que ousaram criar novas teorias, pensar por modos próprios, ia aos poucos me reaproximando do meu próprio mundo, dos interiores do Brasil, me permitindo entende-lo e respeitá-lo. O mundo que me pareceu grande demais quando cheguei ia me dando suporte e abrindo portas para minha atuação, me proporcionando a lida, a mão na massa, o contato diário com o rico acervo literário e teórico que agora tinha abrigo seguro na casa verde do bosque, no coração da PUC-Rio - Campus Gávea. Eu ia encontrando caminhos para contar a história da minha gente, me incluindo no universo dos que pensam a cultura, embrenhando nos desvãos de uma faculdade que ia se mostrando mais próxima das minhas crenças político-social-comunitárias, como gosto de chamar. Vou encontrando ressonância, consonância e parcerias para meus escritos, dizeres e fazeres com a literatura. 


\title{
4 \\ O livro, a leitura e as tecnologias: novas leituras, novas histórias.
}

\author{
Oh Tempo Rei! \\ Transformai \\ As velhas formas do viver \\ Ensinai-me \\ Oh Pai! \\ O que eu, ainda não sei \\ Mãe Senhora do Perpétuo \\ Socorrei!... \\ (Gilberto Gil)
}

Aquele diálogo com Tia Fiinha que resultou no conto "Felicidades, um passeio à beira-mar", encarnado na personagem D. Felícia, teve em mim o impacto que teve a ama quando reconheceu a cicatriz e que abriu espaço dentro do jogo narrativo para os versos da Odisséia que contam a volta de Ulisses, disfarçado de velho mendigo sujo, a seu palácio e seu reconhecimento por sua ama Euricleia, quando esta lhe banha os pés e toca na cicatriz de sua perna. A força e a verdade das palavras na boca de pessoa tão dona de seu desejo de simplicidade me permitem reconhecer a cicatriz, a marca de algo fundamental que eu podia agora reconhecer. Com efeito, não devem ter decorrido dez segundos entre a primeira apalpada de Euricléia e seu grito de susto e de alegria, mas foram suficientes para a tomada de consciência de que estava diante do seu rei. Com a lição de felicidade o reconhecimento se dá à mineira, silencioso, mas o trabalho estava todo por ser feito, a história está para ser descoberta e/ou escrita, toda uma aventura a ser empreendida, e os méritos só poderiam ser narrados anos depois.

$\mathrm{Na}$ Odisseia de Ulisses, Homero discorre em 73 versos o episódio da caça ao javali que resulta na cicatriz reveladora da volta do herói à sua casa. No caso da minha história, a revelação é que levará um grupo de companheiros e toda uma comunidade a uma verdadeira odisseia. $\mathrm{O}$ que eu escrevia literariamente era matéria para muito trabalho, trabalho este de transformação, de tomada de consciência de que era necessário cuidar do que nos pertencia, do que nos constituía, a memória da nossa gente. E tudo só se torna possível porque aparece 
Denise Gusmão, que com mãos e ideias aceitou o desafio de fazer cumprir um destino.

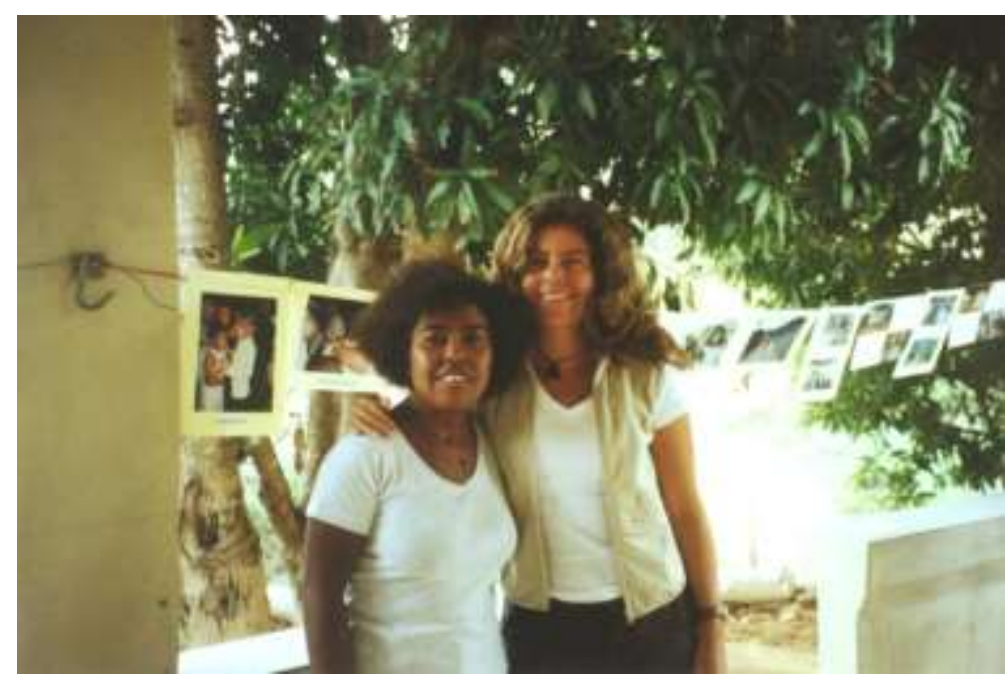

Figura 31: Toquinha, Denise e o varal de histórias

Na casa de pau-a-pique

Recebo a grande lição

A verdadeira riqueza

se faz pelas nossas mãos

Pois que a felicidade

Se for pura, de verdade

Reside é no coração.

Que era coisa muito séria

O meu coração sabia

Saber que o bem do homem

É mesmo a sabedoria

Por isso me emocionava

O que Fiinha falava

E eu logo reconhecia.

Reconhecia que era

Trabalho pra muitos braços

Pra quem conhecia o mundo

Para além dos meus espaços

Do meu quarto de empregada

Senti minhas mãos atadas

Meu conhecimento escasso.

E no meu pouco saber

Senti do destino a trama

Que vinha gente chegando

Pra desfazer o meu drama

E o que se apresentava

Me falta a palavra exata

minha emoção se derrama.
Se apresentava uma chance

De reverter a história

Fadada ao esquecimento

À perda de uma memória

De gente humilde e decente

E de seus muitos descendentes

Merecedores de glória.

Glória na simplicidade

De vida do interior

E que nos constituía

$\mathrm{Na}$ alegria ou na dor

Não podia perecer

E pouco a pouco morrer

Sem entender seu valor.

Foram muitos companheiros

Na nossa longa jornada

Mas foi Denise Gusmão

Chefiando a empreitada

Que por sua intuição

Seguindo seu coração

Caminho certo encontrava.

Quando por fim abrigou

Todo o tesouro encontrado

Numa casa bem singela

Preparada com cuidado

Sentiu que cumprira a sina

Trabalho que não termina

Entregou o seu legado 
Num momento crucial da história da minha comunidade de nascimento, eis que constrói-se uma possibilidade de mudar o seu curso. Denise percebe um trabalho a ser feito, e é também no instante, como quando Euricleia se depara com a cicatriz, que se dá conta de que são muitas coisas ameaçadas de desaparecer cantigas de roda, casas antigas, festas, a sanfona e os sanfoneiros, os afetos, os encontros, o próprio passarinho Inhapim -, a marca potente que contém o germe, um apelo de memória, nas suas palavras. O pedido de socorro desencadeado pelas palavras da psicóloga americana Clarissa Pinkola Estés, em seu livro $O$ dom da história, que eu abraço ao terminar de lê-lo, e que sinaliza que não havia mais tempo de espera, que era momento de ação. Era preciso narrar, lançar mão da palavra.

Seja sua família velha, jovem ou ainda em formação, seja você amante ou amigo, são as experiências compartilhadas com os outros e as histórias que se contam depois sobre essas experiências, além daquelas que se trazem do passado e do futuro, que criam o vínculo definitivo.

Não existe um jeito certo ou errado de se contar uma história. Talvez você se esqueça do início, do meio ou do final. Mas um pouquinho de sol nascendo através de uma pequena janela também anima o coração. Por isso, adule os velhos resmungões para que contem suas melhores lembranças. Peça às criancinhas seus momentos mais felizes. Pergunte aos adolescentes os momentos mais assustadores de suas vidas. Dê a palavra aos velhos. Passe por toda a roda. Force os introvertidos. Pergunte a cada pessoa. Você vai ver. Todos serão aquecidos, sustentados pelo círculo de histórias que criarem juntos.

Embora nenhum de nós vá viver para sempre, as histórias conseguem. Enquanto restar uma criatura que saiba contar a história e enquanto, com o fato de ela ser repetida, os poderes maiores do amor, da misericórdia, da generosidade e da perseverança forem continuamente invocados a estar no mundo, eu lhe garanto que... será suficiente. (ESTÈS, 1998, p. 38-39)

O poder contido no saber do povo, dos contadores de história que povoaram minha infância, e que eu conhecia por vivenciá-lo, por experimentá-lo, era referendado por alguém autorizado a dizer pelo conhecimento acumulado, oficial - uma psicóloga que escrevia livros - e não apenas pela minha emoção de pessoa simples de saber que uma roda de conversa, de contação de histórias, de causos é responsável pela comunicação de coisas sabidas, de transmissão do que se conhece. Os contadores e contadoras de histórias são personagens caros na memória de muitos dos que nasceram naquele meu lugar, o que me traz à memória o texto do filósofo alemão Walter Benjamin. 
A narrativa, que durante muito tempo floresceu num meio de artesão - no campo, no mar, na cidade - é ela própria, num certo sentido, uma forma artesanal de comunicação. Ela está interessada em transmitir o "puro em si" da coisa narrada como uma informação ou um relatório. Ela mergulha a coisa da vida do narrador para em seguida retirá-la dele. Assim se imprime na narrativa a marca do narrador, como a mão do oleiro na argila do vaso. (BENJAMIN, 1994. p. 205)

Lembro, com esta passagem do texto de Benjamin, que meu pai foi de fato, oleiro. Quando eu era muito menina, meu pai e seus irmãos fabricavam tijolos e telhas bem no quintal de nossa casa, e esse espaço do fazer e da troca era vivo, presente. Enquanto os homens trabalhavam, eu e meus primos brincávamos e vez por outra nos deixavam fabricar também; e quando já havia grande quantidade de tijolos e telhas secas pelo sol e acumuladas ao longo de muitos dias de trabalho, vinha a noite da queima em que faziam um enorme forno com os tijolos e telhas empilhados que passavam a noite literalmente ardendo em chamas; e a noite inteira os homens contando causos, conversando amenidades. Na verdade virava uma grande festa, pois aquele era um trabalho demorado. Pacientemente esperavam que o fogo se consumisse por longas horas e desse durabilidade ao produto de seu trabalho. E narravam experiências miúdas do dia-a-dia, compartilhavam.

Essas atividades comunitárias das quais participei, e que me marcaram, demonstram a convivência entre gerações, hábitos que proporcionavam espaços férteis de experiências onde ainda a narrativa era possível. E quando Gagnebin escreve sobre a história da cicatriz de Ulisses que torna-se um dispositivo para que o herói possa narrar seus feitos durante a longa viagem, me leva de volta ao ponto inicial deste capítulo.

Na história da ferida que se transformou em cicatriz encontramos, então, as noções de filiação, de aliança, de poder da palavra e de necessidade da narração. Encontramos também o motivo da viagem de provações e do regresso feliz à pátria, depois da errância. Todos esses temas culminam no reconhecimento pleno, mesmo que postergado por ele mesmo, do herói. Essa conjunção feliz marca, até hoje, as narrativas do Ocidente, desde os contos de fada até as novelas de televisão, sem esquecer a tragédia e o romance. Quando Walter Benjamin fala do fim da narração e o explica pelo declínio da "experiência" (Erfahrung), ele retoma exatamente os mesmos motivos: a continuidade entre as gerações, a eficácia da palavra compartilhada numa tradição comum e a temática da viagem de provações, fonte da experiência autêntica - mesmo que seja para afirmar que estes motivos perderam suas condições de possibilidade na nossa (pós) modernidade. A cicatriz de Ulisses nos prometia, pois, que a história, apesar de todos sofrimentos, terminaria bem. Parece que até hoje escutamos ressoar o barulho da bacia que Euricléia derruba, vemos a água se esparramar no chão da sala escura e gostaríamos de acreditar 
nessa bela, mesmo que diferida, promessa de reconhecimento e de realização. (GAGNEBIN, 2006. p. 109)

O momento de tomada de consciência, o alerta para o perigo do desaparecimento da história e meu apelo de memória, permitem que nossa história possa ser contada e ressignificada. Denise Gusmão (2009, p. 40), em sua tese de doutorado, lembra que nas minhas narrativas literárias, no meu apelo também estão as noções de filiação, de aliança, de poder da palavra e de necessidade da narração, pois há um momento em que é necessário narrar e para tanto é preciso ter um narrador.

Para poder relatar seus sofrimentos, uma pessoa precisa antes de mais nada encontrar uma escuta, nos diz Michael Pollak (1989, p.6). A dor que Toquinha anuncia é a dor do esquecimento do seu povo. Seu apelo é um apelo de memória. Coloquei-me na escuta não só da dor mas também da vida, e encontrei na literatura de Maria de Lourdes Souza o poder da palavra.

Toquinha: O meu Dicionário de Lembranças foi organizado pensando nisso. As histórias precisavam contar a minha história, e de um jeito que emocionasse, que fosse bonito, mesmo que às vezes duro, como no conto "Simplesmente amor", que fala da morte dos meus pais, da beleza singela do amor deles e da dor da despedida eterna. E eu fiz questão de fechar o livro com o "Felicidades, um passeio à beira-mar" por acreditar que assim o livro se fechava mostrando uma possibilidade de mudança. A lição de felicidade escrita ali poderia, quem sabe, sensibilizar para a transformação.

A consciência de Toquinha e sua relação com a escrita e com a literatura me lembram o pensamento de um escritor por quem ela e eu temos profunda admiração:

Que processo de mudança pode impulsionar um povo que não sabe quem ele próprio é, nem de onde vem? Não sabendo quem é, como poderá saber o que merece ser? Não poderia a literatura ajudar a que, direta ou indiretamente, uma tal revelação fosse efetivada? Penso que a possibilidade de contribuição dependerá em grande parte do grau de intensidade da comunhão do escritor com as raízes, os movimentos e o destino de seu povo; dependerá também de sua sensibilidade para perceber as batidas, o som e o ritmo da autêntica contracultura em ascensão. Muitas vezes, o que se considera "incultura" contém sementes ou frutos de uma "outra" cultura, que enfrenta a cultura dominante apesar de não ter seus valores nem sua retórica. É costume desprezá-la, erradamente, considerandose uma mera repetição degradada de produtos "cultos" da elite ou dos modelos culturais que o sistema fabrica em série; entretanto, uma historinha de cordel é frequentemente mais reveladora e valiosa do que um romance "profissional" - o pulso da vida real se sente com mais força em certos versos anônimos do cancioneiro popular do que em muitos livros de poesia, escritos no código dos iniciados; os testemunhos do povo, que expressam suas lamentações e esperanças de mil maneiras diferentes, são em geral mais eloquentes e belos do que obras escritas "em nome do povo" (Galeano, 1978, p.19). 
Denise cumpre um papel, e juntas empreendemos uma luta para escavar a história e repensar nossas práticas de comunidade. Eduardo Galeano, escritor e ativista político nascido no Uruguai, escreve sobre o poder da palavra e o papel da literatura. A lembrança de que a minha consciência e a minha relação com a escrita e a literatura entram em sintonia com o pensamento de um escritor que eu admiro por inúmeras razões além do próprio texto, evidenciam que o trabalho de memória e de escrita demanda, na minha percepção, um desejo e um suporte para que possam emergir. Muitos versos dessa história ameaçada de desaparecimento são construídos pelo trabalho delicado de escuta para as muitas histórias libertadas desde aquele meu apelo de memória. Ao modo da digressão nos 73 versos que faz o personagem Ulisses a partir da cicatriz percebida por sua ama, os versos de uma outra história são escritos, e encontram abrigo na Casa de Memória e Cultura do Córrego dos Januários, uma casa para onde voltam o nossos heróis, nossos tantos e modernos Ulisses com tantas histórias a serem conhecidas. A Casa de Memória tornou-se, depois de muito desbravarmos o mar de nossa história, um lugar de memória, de lembrança e de construção, um jeito novo de sermos comunidade. E que também anuncia que tudo pode acabar bem, uma promessa de reconhecimento e realização. Na fotografia abaixo, ao meu lado Monsenhor Raul Mota, que também cedeu a casa da família para criação do Museu Casa do Bentoca na cidade de Inhapim.

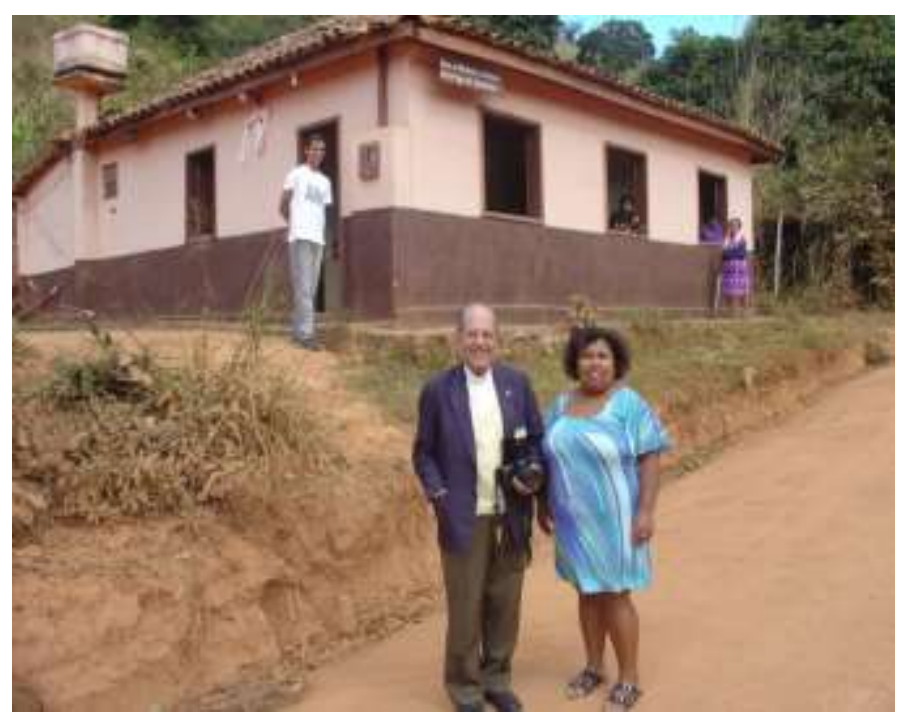

Figura 32: Casa de Memória e Cultura do Córrego dos Januários, em dia de visita 
Lancei meu livro "Dicionário de Lembranças" em 1998, no Rio de Janeiro. E ainda não havia falado sobre ele na escola onde estudei quando criança até o dia em que visitamos a escola naquele ano de 2002. Sempre fiquei tímida, pouco à vontade para falar do que escrevia. Falar sobre mim mesma pareceu-me sempre um despropósito, mas durante o processo de intervenção na Escola Municipal Elias Januário (Sede e Anexa), onde eu também estudei quando criança, tive uma inesquecível conversa com os alunos sobre meu livro. Denise me incentivava, cúmplice do meu processo de afirmação. E naquele momento fazia sentido, afinal eu tinha uma experiência que podia ser útil aos alunos e professores. E aceitei o desafio.

Nos dois encontros que fizemos nas escolas do Córrego, Toquinha falou de seu livro "Dicionário de Lembranças". Em seu relato a escritora fazia uma ponte entre o livro e as histórias que ouvia quando menina, valorizando ao mesmo tempo a narrativa oral e escrita. Além disso, seus contos são todos inspirados no Córrego dos Januários, o que possibilita uma identificação total dos leitores e ouvintes dali. (GUSMÃO, 2004, p. 166)

A conversa com as crianças em roda, sentadas no chão do pátio da escola, foi comovente. Para elas foi uma surpresa saberem que eu tinha escrito um livro. E a curiosidade e a proximidade que tinham comigo as autorizava a fazerem as perguntas mais singelas e sinceras que eu poderia esperar.

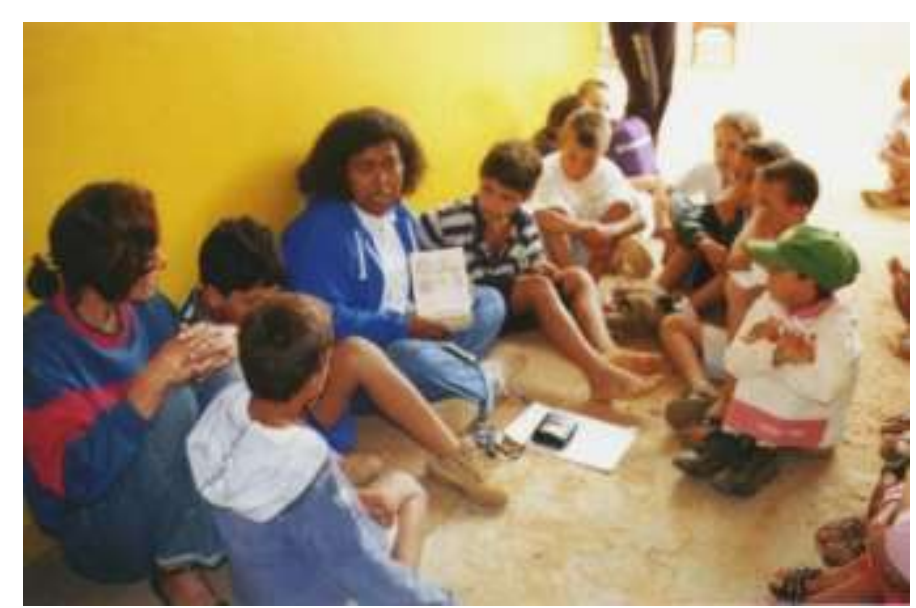

Figura 33: Toquinha sendo entrevistada por alunos da Escola Municipal Elias Januário (Foto de Denise Gusmão)

Toquinha: Eu queria falar um pouquinho também da importância dessa contação de história, né, porque olha só, esse livro aqui se chama "Dicionário de Lembranças" e fui eu que escrevi. Quando eu escrevia as histórias e pensava nos costumes do Januário, eu pensava no meu Tio Geraldo Domingos, porque eu queria 
contar como se ele contasse. O Tio Geraldo Domingos foi quem me inspirou porque ele contava muita história quando eu era criança.

Rafael: Mas como que a gente pode escrever um livro grande desse?

Toquinha: Ah, isso a gente vai escrevendo. Demora, assim, um tempo. Você não pega de uma vez. Eu, esse livro eu fazia, lá no Rio de Janeiro eles chamam Oficina de Literatura, que é você juntar um grupo de pessoas pra poder estudar, ler livros, e aí a gente escreve história. Daí lê as histórias da gente pros outros.

Felipe: Aqui na nossa escola faz campeonato de poesia.

Dayane: Você faz isso aqui, as letras, de quê?

Toquinha: Ah, isso aqui foi feito no computador. Quem fez, quem colocou isso aqui no computador... Tudo que a gente escreve a gente digita, bate no computador, coloca no computador, aí lá dentro a gente arruma do jeito que a gente quer. Coloca do tamanho que a gente quer a letra. Porque tem vários tipos de letra no computador, você pode escolher. Aqui dentro tem vários tipos de letra, tem uma letra que se chama itálico, que é mais deitadinha assim. Tem uma letra itálico, essa aqui já é uma letra normal. As letras têm nome.

Dayane: De quê que fala o livro?

Carlos: Toquinha, como você começou a escrever o livro?

Felipe: Custa quanto?

Ricardo: Toquinha, mas como é que a gente não erra nos livros?

Carlos: O primeiro livro que você fez ficou com você ou levaram? (GUSMÃO, 2004, p. 167)

Fiquei muito emocionada. Eu era naquele instante a escritora com seus pequenos leitores. Era uma nova relação. Até então eu não havia parado para pensar o meu processo de escrita. Era um aprendizado falar de mim para os meus. Eu me autorizava a narrar-me. Eu era ali a voz que transitava entre o campo de pesquisa e a Academia; quem aprendia e experimentava ser de outro modo.

Aprender a narrar-se poderia ser o benefício dessa apropriação crítica. Aprender a narrar-se é também aprender a narrar a si mesmo de outro modo.

Com essa expressão, "de outro modo", uma problemática inteira é colocada em movimento, a da identidade pessoal associada ao poder narrar e narrar-se. (RICOEUR, 2006, pg. 115)

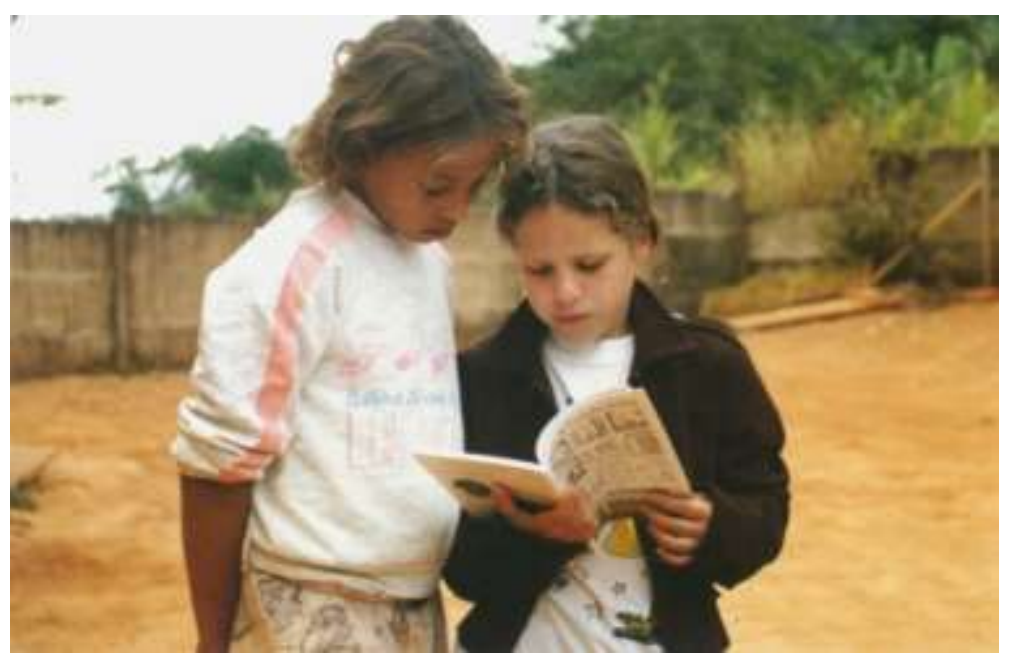

Figura 34: Marlene e Dayane lendo o livro "Dicionário de Lembranças" (Foto de Denise Gusmão) 
Esse encontro com meus leitores ia sedimentando meu lugar na comunidade. No meu aprendizado do gosto pela leitura e pela escrita eu me tornava, ou me afirmava, outra. Eu me reconhecia no olhar curioso do menino que não podia acreditar que eu escrevera um livro tão grande. Naquela cidade que sequer tem livraria, que o livro é artigo de luxo que figura nas estantes das salas de professores, eu era alguém que escrevia a história inspirada na estrada de terra, nos costumes, nas pessoas próximas. Aquele foi um reencontro comigo mesma. Terminada a conversa eu pensava nos caminhos por onde a leitura me levava. Com Eliana Yunes, vou entendendo o que intuitivamente eu fazia na prática.

"A leitura literária descortina horizontes e subverte a realidade, para iluminá-la. Isso não quer dizer que a literatura seja panfletária, exista para promover esta ou aquela ideia - o que até pode acontecer, mas isto acaba por comprometer o texto do autor com interesses estranhos a arte. O leitor - um co-autor, uma vez que a recebe e redimensiona, preenchendo os sentidos com uma interpretação -, tem na leitura um instrumento de prazer e conhecimento do mundo. Ler muito, profundamente, permite descobrir-se a si mesmo e aos outros." (YUNES, 1988. p.08)

O exercício da leitura abriu meus olhos para outros mundos me possibilitando também a escrita.

A Casa de Memória e Cultura do Córrego dos Januários surge, então, como resultado do amplo trabalho de pesquisa realizado por Denise Sampaio Gusmão, no Programa de Pós-graduação em Psicologia Clínica do Departamento de Psicologia da Pontifícia Universidade Católica do Rio de Janeiro, sob a orientação da professora Solange Jobim e Souza. O projeto foi desenvolvido com a participação da comunidade do Córrego dos Januários, e está vinculado à Associação de Desenvolvimento Comunitário do Córrego dos Januários. A elaboração e o desenvolvimento deste projeto contaram com o apoio da CAPES, do CNPq, da Vice Reitoria Comunitária da PUC-Rio e com a parceria do Departamento de Artes \& Design da PUC-Rio, através do professor Luis Vicente Barros. Todas as pessoas envolvidas trabalharam com muito cuidado, atentos às delicadezas que implicavam o processo. Dentro da Casa eu fiz questão de que tivesse a Sala de Leitura.

Narrar a mim mesma, os meus e a minha comunidade é um aprendizado, e o será sempre. O caminho do Córrego dos Januários até o Rio de Janeiro, e à PUC- 
Rio foi traçado na liberdade da diferença, pois ser fixado na diferença é ser servo; ser livre em relação à diferença é ser senhor (RICOEUR, 2006, 192).

E agora, que minha memória permitiu que aflorassem tantas lembranças, que vi reconstituído todo um percurso, me pego pensando nos versos de Drummond (2002).

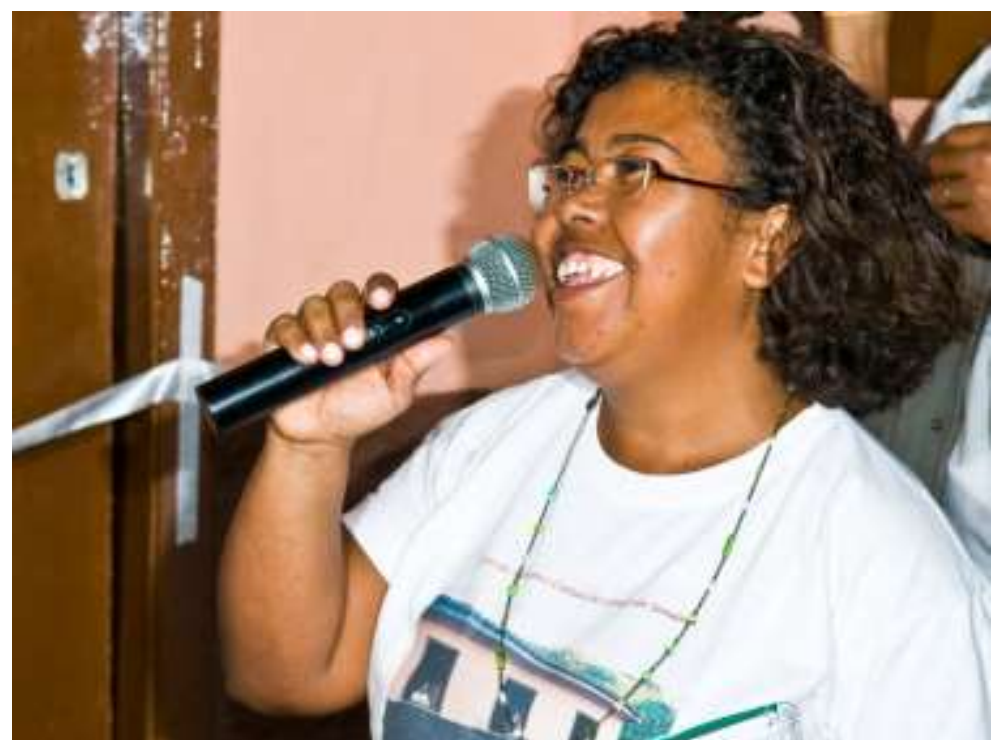

Figura 35: Toquinha na inauguração da Casa de Memória e Cultura (foto de Ana Andrade)

Meu pai montava a cavalo, ia para o campo.

Minha mãe ficava sentada cosendo.

Meu irmão pequeno dormia.

Eu sozinho menino entre mangueiras

lia a história de Robinson Crusoé,

comprida história que não acaba mais.

No meio-dia branco de luz uma voz que aprendeu a ninar nos longes da senzala - e nunca se esqueceu chamava para o café.

Café preto que nem a preta velha café gostoso

café bom.

Minha mãe ficava sentada cosendo olhando para mim:

- Psiu... Não acorde o menino.

Para o berço onde pousou um mosquito.

E dava um suspiro... que fundo!

Lá longe meu pai campeava no mato sem fim da fazenda.

E eu não sabia que minha história era mais bonita que a de Robinson Crusoé.

(Carlos Drummond de Andrade, 1996) 


\section{1}

\section{Gratidão: dar, receber, retribuir - O Clubinho de Leitura}

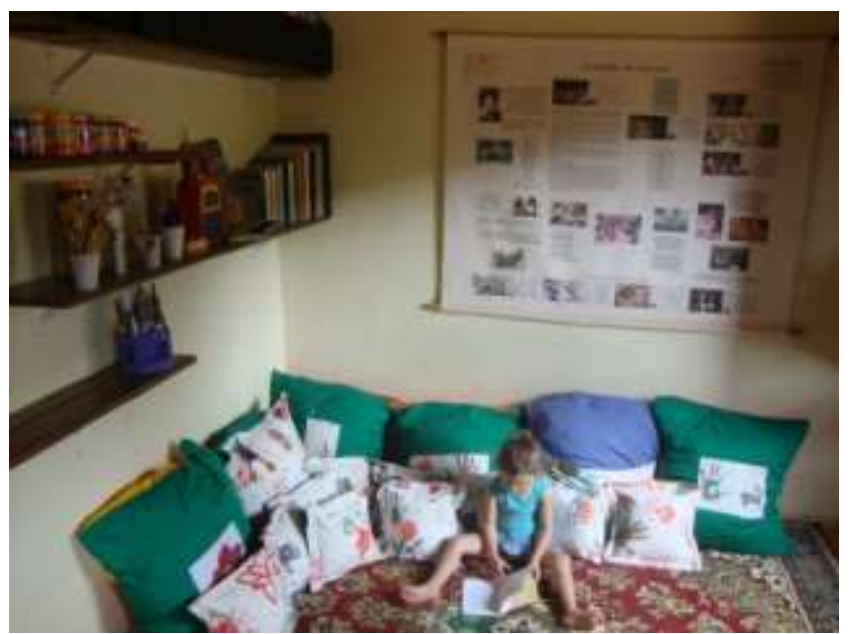

Figura 36: Sara lendo (Foto de Sávio)

Tenho um livro sobre águas e meninos.

Gostei mais de um menino que carregava água na peneira.

A mãe disse que carregar água na peneira era o mesmo que roubar um vento

e sair correndo com ele para mostrar aos irmãos.

A mãe disse que era o mesmo que catar espinhos na água

O mesmo que criar peixes no bolso.

O menino era ligado em despropósitos.

Quis montar os alicerces de uma casa sobre orvalhos.

A mãe reparou que o menino gostava mais do vazio do que do cheio.

Falava que os vazios são maiores e até infinitos.

Com o tempo aquele menino que era cismado e esquisito porque gostava de carregar água na peneira

Com o tempo descobriu que escrever seria o mesmo que carregar água na peneira.

No escrever o menino viu que era capaz de ser noviça, monge ou mendigo ao mesmo tempo.

O menino aprendeu a usar as palavras.

Viu que podia fazer peraltagens com as palavras. E começou a fazer peraltagens.

Foi capaz de interromper o voo de um pássaro botando ponto final na frase.

Foi capaz de modificar a tarde botando uma chuva nela.

O menino fazia prodígios.

Até fez uma pedra dar flor!

A mãe reparava o menino com ternura.

A mãe falou: Meu filho você vai ser poeta.

Você vai carregar água na peneira a vida toda.

Você vai encher os vazios com as suas peraltagens e algumas pessoas vão te amar por seus despropósitos

(Manoel de Barros, 1999) 
Toda a minha relação de amor com a leitura e a escrita me inspiraram para a criação do clubinho de Leitura, um projeto de formação de leitores que funciona com muita simplicidade, tendo como monitores um grupo de adolescentes e jovens voluntários. Essa ideia nasceu de uma coleção de 15 gibis doados por Denise. Era para serem distribuídos, uma lembrança dela para os meninos com as quais fizera amizade logo na primeira ida ao Córrego, mas eu tive a ideia de reunir as crianças para lerem juntas ao invés de dar uma revistinha para cada um. Naquele nosso primeiro encontro eu não tinha noção da real possibilidade de que a ideia se desenvolvesse, mas Janaina Costa, que tinha por volta de 15 anos, se ofereceu para cuidar dos gibis e seguir com os encontros enquanto eu estivesse no Rio, pois minhas idas e vindas entre o Rio e o Córrego eram bimestrais ou mais espaçadas, já que além de acompanhar Denise na sua pesquisa eu tinha minhas responsabilidades do trabalho que me dava o sustento.

Janaina: Lembro que tínhamos muitas revistinhas da Mônica . Eu adorava ler. Olha, eu gostava de ver as crianças sorrindo, quando a gente se reunia algumas faziam desenhos, contavam historias e tudo começou em um tapete, livros espalhados, e crianças sentadas no chão.

Janaína guardava os gibis em casa, aos sábados ela levava nossa gibiteca para a varanda da casa de Joversino Januário e sua esposa Lourdes, se reunia com os outros adolescentes e crianças, liam juntos, e depois levava a caixa de gibis de volta para casa. A ideia funcionou, e na viagem seguinte levei a primeira mala de livros doados por amigos.

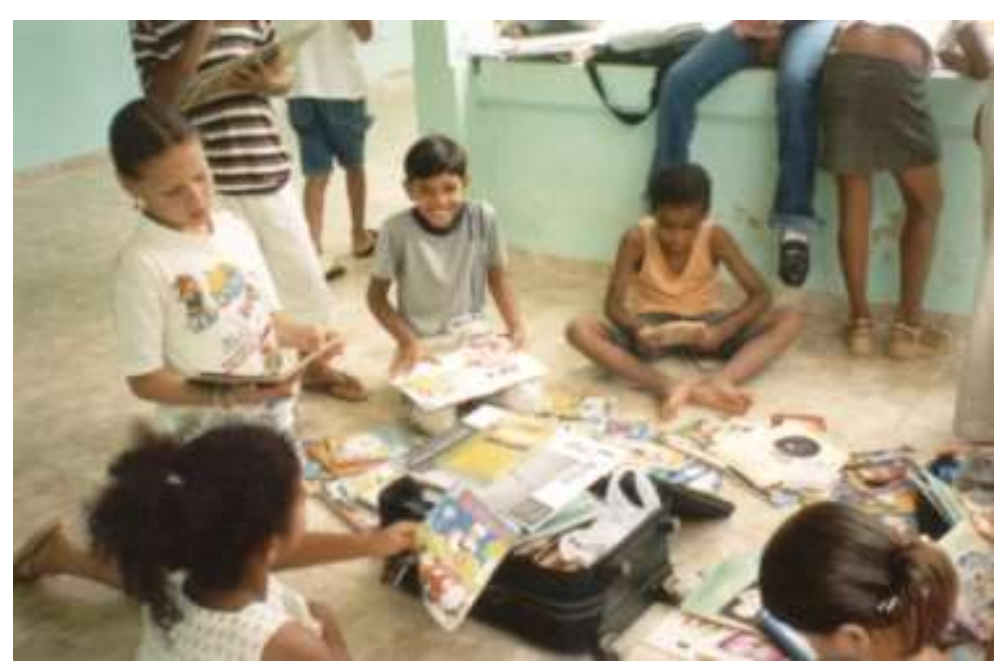

Figura 37: A primeira mala de livros 
Com a nova leva de livros não era mais possível Janaína transportar nossa pequena biblioteca em caixas, então Joversino, que já nos permitia utilizar a varanda de sua casa para as reuniões aos sábados, nos cederam uma pequena sala numa casa, também de sua propriedade, onde aconteciam algumas reuniões comunitárias e passamos a dividir a casa com o grupo dos Alcóolicos Anônimos. Nascia assim o clubinho de Leitura.

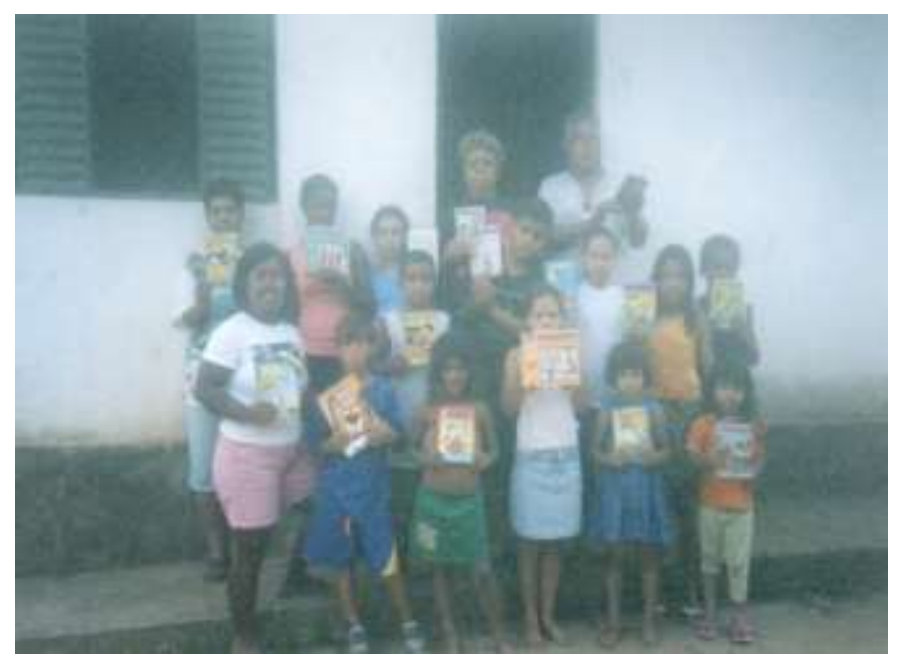

Figura 38: O Clubinho de Leitura na sua primeira casa

Toquinha: O Clubinho de Leitura é a menina dos meus olhos, pois sinto que ali é lugar onde eu dou continuidade a uma história. Para mim conhecimento só tem utilidade se é compartilhado, se entra na massa-do-bolo-do-mundo. Conhecimento trancado em mentes, por mais brilhantes que sejam, de nada servem se não transformam a realidade do mundo - ainda que o alcance do seu mundo, fisicamente falando, seja a casa do seu vizinho - ou a preservem, se for o caso. O saber, a experiência existe para nos enriquecer, para nos tornar melhores, homens melhores. Saber ler e escrever de verdade é a porta para a liberdade. E é pensando assim que eu me dedico ao Clubinho de Leitura. Neste trabalho coloco minha crença de que o que eu aprendi e me serviu de porta para a liberdade e para a minha afirmação como pessoa, de pouco terá serventia se ficar encerrada em mim. Eu quero transmitir o que recebi da vida. (GUSMÂO, 2009, p. 224)

O nosso aprendizado sempre se deu pela prática e na partilha. Era na experimentação que descobríamos modos de lidar com nossa ideia de biblioteca. Até então eu só tinha o gosto de ler e de escrever e, por isso, o desejo de criar um lugar para leitura; eu ainda não tinha nenhum conhecimento técnico ou acadêmico do assunto, apenas a certeza de que os livros são grandes companheiros e são capazes de nos levar a conhecer muitos mundos. Ao descobrir a delícia de ler um bom livro, encantar-me com as tantas histórias que li, sofrer com outras, e tendo descoberto isso somente na idade adulta, eu havia decidido que dali por diante eu 
trabalharia para tornar o acesso ao livro mais democrático e divertido, pensando principalmente nas crianças e adolescentes, em propiciar a possibilidade do encontro com o livro logo nos primeiros anos de vida.

Com o trabalho de Denise já bastante adiantado era momento de procurarmos um espaço adequado e definitivo para receber o material que desde a concepção do projeto tinha a proposta de ser entregue à comunidade. Então, enquanto buscávamos esse lugar para concretizarmos o que depois se chamou Casa de Memória e Cultura, eu e minhas irmãs nos demos conta de que a nossa casa, herança de nossos pais, estaria desocupada em pouco tempo e não tínhamos intenção de voltar a morar lá, nem de cedê-la a outro morador. Nossas vidas já nos levavam para outros endereços, e achamos por bem oferecer a nossa casa para tornar-se a Casa que abrigaria a Memória e a Cultura do Córrego dos Januários.

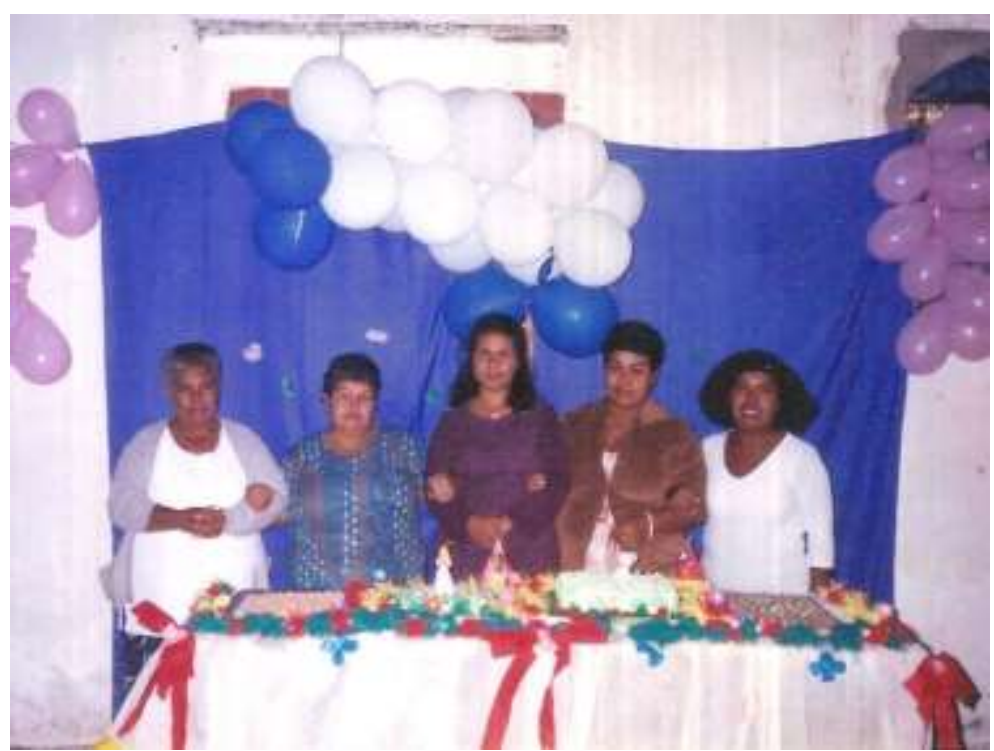

Figura 39: As irmãs Marlene, Teresinha, Dorvalina, Isabel e Maria de Lourdes

Assim foi feito. Nossos contos, imagens e livros ganharam lugar seguro. O professor do Departamento de Arte e Design da PUC-Rio Vicente Barros fala da sua primeira impressão da Casa a ser transformada na Casa de Memória. 


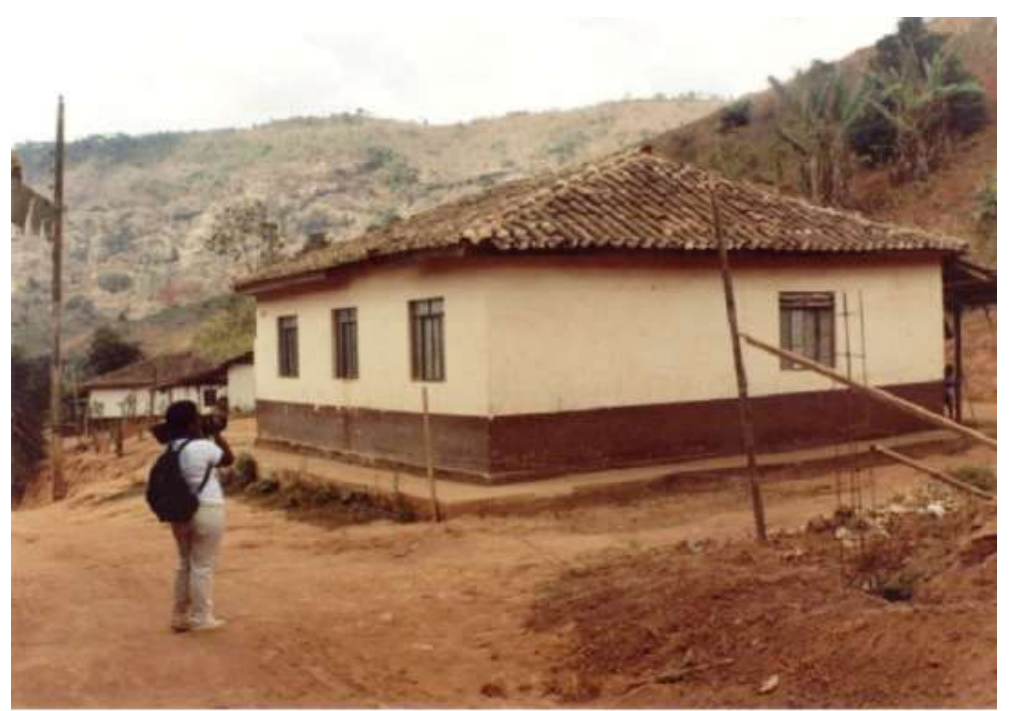

Figura 40: A Casa, herança de nossos pais (Foto de Denise Gusmão)

Viajamos 9 horas de carro. Chegamos ao Córrego dos Januários e fomos para a casa da Jupira, prima de Toquinha, onde iríamos ficar hospedados. A casa da Jupira: linda e aconchegante, café e broa, muito carinho e o quarto dos pais para descansarmos. Demos uma descansada depois e por volta das $6 \mathrm{~h}$ fomos à casa de Toquinha, onde será a Casa de Memória, onde acontece o Clubinho de Leitura. Havia várias crianças, estavam fazendo o natal deles e nos aguardavam. Eles leram poemas, recitaram versos, Juninho recitou um poema que gravou na memória. Os jovens Deo (Edervanio) e Dayane leram o conto de Toquinha, essa era a primeira vez que as crianças liam e apresentavam contos e poesias. Toquinha ficou emocionada ao ver a apresentação que também era direcionada à ela. Os destaques da noite foram os vagalumes, muitos vagalumes que iluminavam o caminho fazendo parecer que o céu continuava na terra. (GUSMÃO, 2009, p. 205)

Aquele foi um dia lindo também para nós da comunidade. Era a primeira vez que o Clubinho de Leitura se preparava para receber visita lendo verso e prosa. Era bom ver a casa cumprindo sua função antes mesmo de ser preparada e inaugurada.

\section{2}

\section{O Córrego chega ao Rio, o Clubinho cruza montanhas...}

Denise Gusmão era figura constante em nossa comunidade. E suas visitas, sempre cheias de perguntas por parte dos moradores: o que essa moça tanto quer saber? Porque uma pessoa que não é daqui se interessa pela nossa vida? O que ela vai fazer com tudo isso? E inicialmente as perguntas eram sempre com um ar de desconfiança, mas ela foi ganhando a confiança e a amizade de todos. 
Essas perguntas e suas respostas foram ficando claras também para mim durante o processo. Eu também buscava respostas.

A minha crença no poder que um livro tem de transformar vidas era não por ouvir falar, por estudar o assunto, mas por tê-lo vivido. E o Clubinho de Leitura era o espaço de troca, de retribuição do que eu havia recebido da vida. Um desafio.

A participação da comunidade sempre foi a alma do Clubinho, que tem sido o coração da casa. Considero assim porque é a partir dele que as coisas acontecem. Ainda na concepção do projeto Casa de Memória e Cultura por Denise, o trabalho com as crianças e os adolescentes frequentadores foi bastante intenso com a participação nas oficinas de fotografia, na confecção dos cartões postais do Projeto Carta Para-ti, no intercâmbio com outros projetos e cidades. Estas ações propostas pela pesquisadora nos proporcionaram o encontro com outras culturas, com outras histórias, e nos alimentou como fortalecedor da nossa identidade, no conhecimento da nossa própria força como comunidade.

O Carta Para-ti foi idealizado quando no processo da pesquisa, que incluía a preparação da casa e do material a ser exposto, surgiram muitas dificuldades. Havia um grupo de adolescentes e crianças e adultos que estava sempre participando das atividades propostas e muito interessado, mas alguma coisa impedia as ações mais concretas. Mas, ainda que com todos os contratempos, permanecia aceso o desejo comunitário de que uma casa como abrigo para nossa história se tornasse realidade. E o Clubinho ia se tornando um ponto de encontro e de discussões, de intercâmbio de histórias entre os mais velhos, as crianças e os adolescentes, terreno fértil para a semeadura de novas possibilidades.

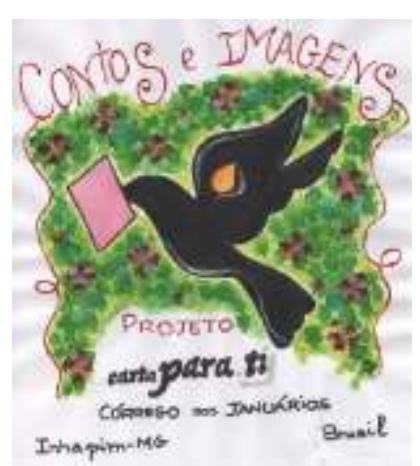

Por ter se apresentado num momento difícil para Toquinha, abalada pela tristeza por causa da demolição da tapera, compreendi o inhapim como alegoria de esperança. No entanto, quando tudo parecia estagnar, recorri aos sentidos de memória e esperança vislumbrados no pássaro inhapim e o nomeamos nosso pombo-correio.

Começava a nascer o projeto "Carta para-ti" em que algumas das fotos produzidas por mim e pelos moradores nas oficinas de fotografia e memória se transformaram em cartões-postais.

O "Carta para-ti" foi desenvolvido em parceria com a designer Luiza Kramer Bazílio, aluna de graduação do Departamento de Artes e Design da PUC-Rio. O projeto, envolvendo fotos-postais, teve sua inspiração no III Festival Literário de Paraty (RJ), onde Toquinha se deparou com desenhos-postais feitos pelas crianças dessa cidade no projeto "Arte na Praça”, em 2006. O 
trabalho realizado por professoras numa oficina de postais, em que as crianças faziam desenhos sobre Paraty e enviavam aos amigos, nos levou a pensar em transformar em postais nosso acervo fotográfico da memória do Córrego dos Januários. (GUSMÂO, 2009, p. 123)

Com o Carta Para-ti, as professoras Lúcia e Branca, os então adolescentes, Edervanio, Débora, Fabiane e Dayane, viajaram para Paraty, cidade histórica do sul do Rio de Janeiro, onde acontece a FLIP (Festa Literária Internacional de Paraty) para participarmos do evento Arte na Praça, atividade da FLIPinha que é a FLIP realizada pelas escolas de Paraty e projetos convidados, onde realizamos a Oficina Carta Para-ti. Fizemos um grande varal de fotografias e preparamos uma mesa com os postais que continham, além da fotografia, uma mensagem da pessoa que aparecia na foto ou que tinha produzido a fotografia. Os visitantes passavam pela nossa mesa, liam os postais e tinham a oportunidade de responder. E recebemos muitas visitas que colocaram suas mensagens/resposta em nossa caixa de correio.

\section{$\operatorname{Postal}^{8}$ com mensagem de Elizete}
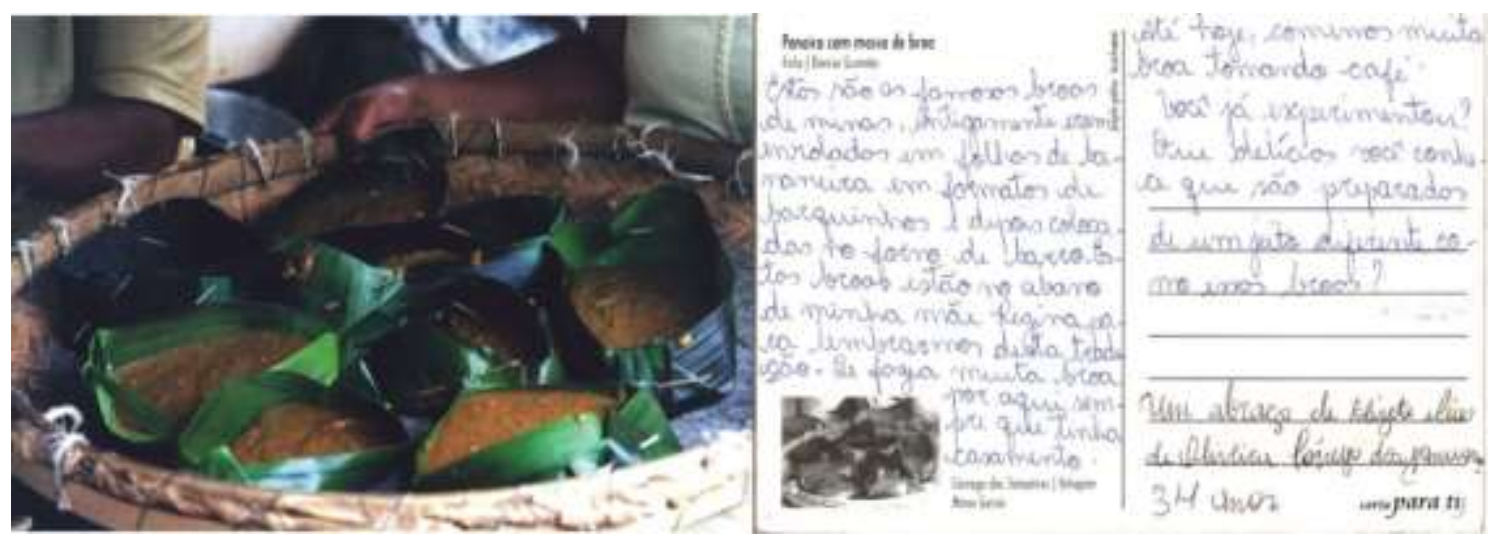

Figura 41: Postal com mensagem de Elizete

Estas são as famosas broas de Minas. Antigamente eram enroladas em folhas de bananeira em formatos de barquinhos e depois colocadas no forno de barro. Estas broas estão no abano de minha mãe Regina, para lembrarmos dessa tradição. Se fazia muita broa por aqui, sempre que tinha casamento. Até hoje, comemos muita broa tomando café. Você já experimentou? Que delícias que você conhece que são preparadas de um jeito diferente como essas broas? Um abraço de Elizete Dias de Oliveira - Córrego dos Januários - 34anos

8 Todos os postais incluídos nesta dissertação foram retirados de: GUSMÃO, Denise Sampaio. Narrativa, Testemunho e Delicadeza: a Casa de Memória e Cultura do Córrego dos Januários. Orientadora: Solange Jobim e Souza. Rio de Janeiro: PUC/RJ, Departamento de Psicologia, 2009. 
Resposta de Bárbara A. Canonia, de São Paulo, para Elizete
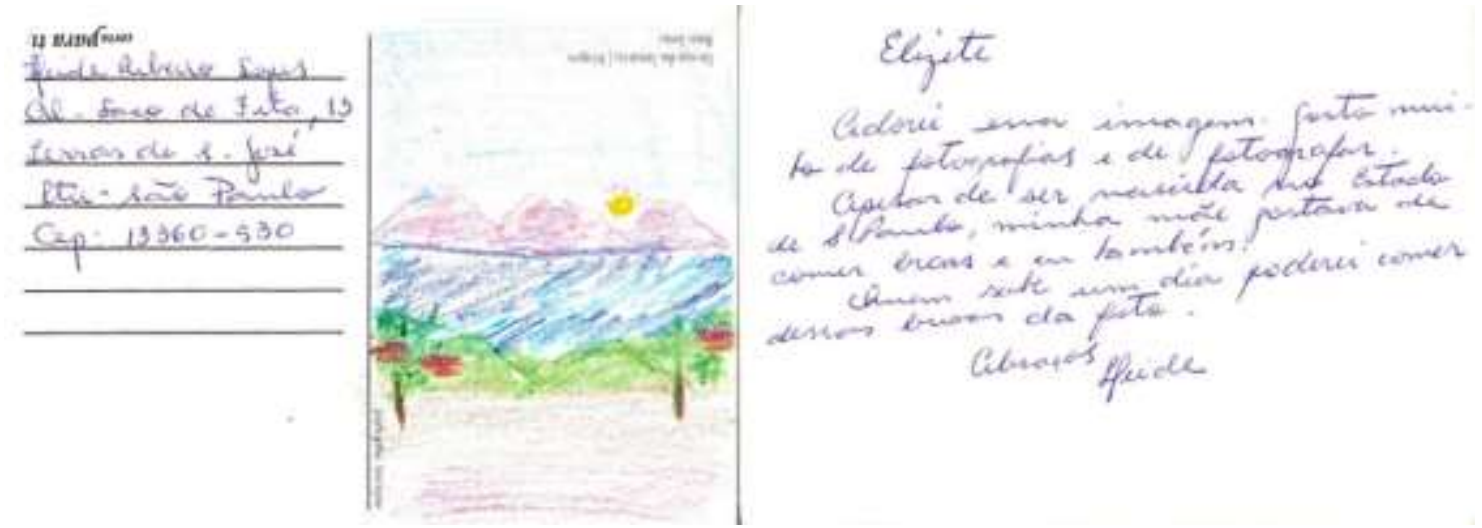

Figura 42: Resposta de Bárbara para Elizete

De: Barbara A. Canonia Para: Elizete Dias de Oliveira - Córrego dos Januários Parabéns pela redação sobre as broas. Você é uma pessoa sortuda por ter a experiência de comer a broa. Eu nunca comi broa. Eu não conheço nenhuma mas gostaria de conhecer. (2009, p.137)

As respostas nos surpreendem, pois pensávamos que o público não se interessaria muito pela nossa história, mas mensagens muito significativas são escritas para as pessoas dos nossos postais. Nesse intercâmbio vamos nos encontrando com muitos outros e com nós mesmos. Vamos nos sentindo parte de um mundo maior.

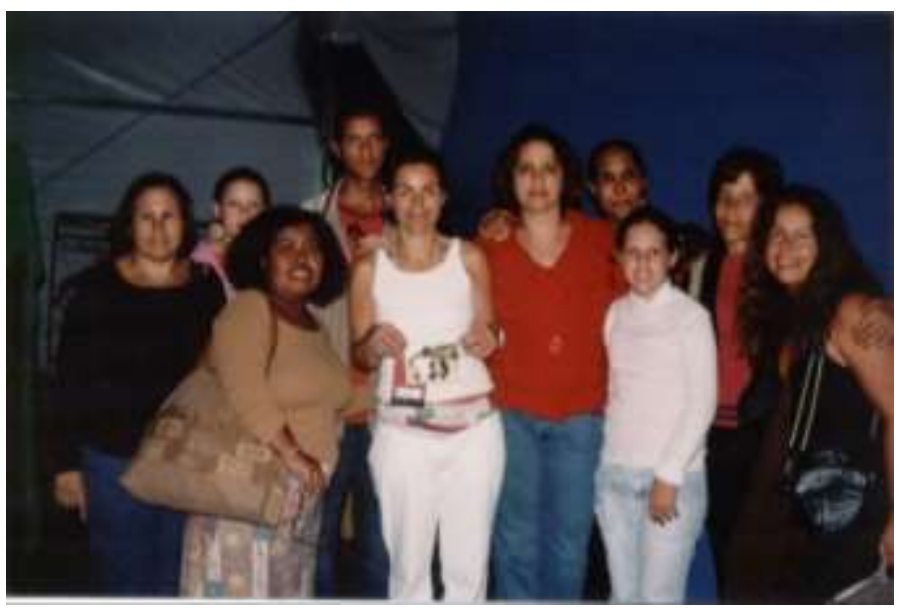

Figura 43: Nosso grupo encontra Gabriela Gibrail, então curadora da FLIPinha (2009, p. 166)

Tivemos oportunidade de fazer a oficina em mais dois lugares, no PUC PELA PAZ, na PUC-Rio, e no Projeto Paiol de Histórias da Fundação Cultural Casa Lygia Bojunga, coordenado por Francisca Valle, que acontece em Pedro do 
Rio, distrito de Petrópolis (RJ). O adolescente Thalles e a professora Rita de Cássia também participaram das oficinas de Pedro do Rio e do Rio de Janeiro. E continuamos nos surpreendendo. Ali nos Pilotis da PUC-Rio muitas respostas foram colocadas na nossa caixa de correio. E nós fomos recebidos pela prof. Solange Jobim e Souza e Denise Gusmão no Departamento de Psicologia.

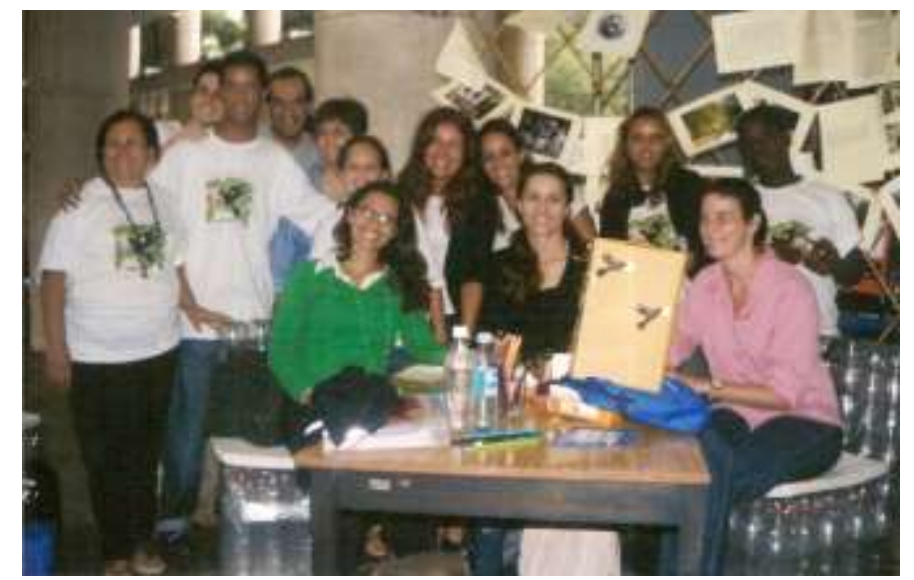

Figura 44: Representantes do Clubinho e participantes da oficina colocando seus postais em nossa caixa de correio - Evento PUC pela PAZ. (2009, p. 167)

Alguns postais foram endereçados ao Clubinho, uma mensagem de incentivo aos novos leitores.

A autora Lygia Bojunga, além de nos receber em seu Paiol de Histórias, conversar conosco sobre nossos processos de trabalho, de lida com a leitura e com a escrita, nos escreve externando seu desejo de que continuemos próximos, intercambiando sobre livros e leituras.
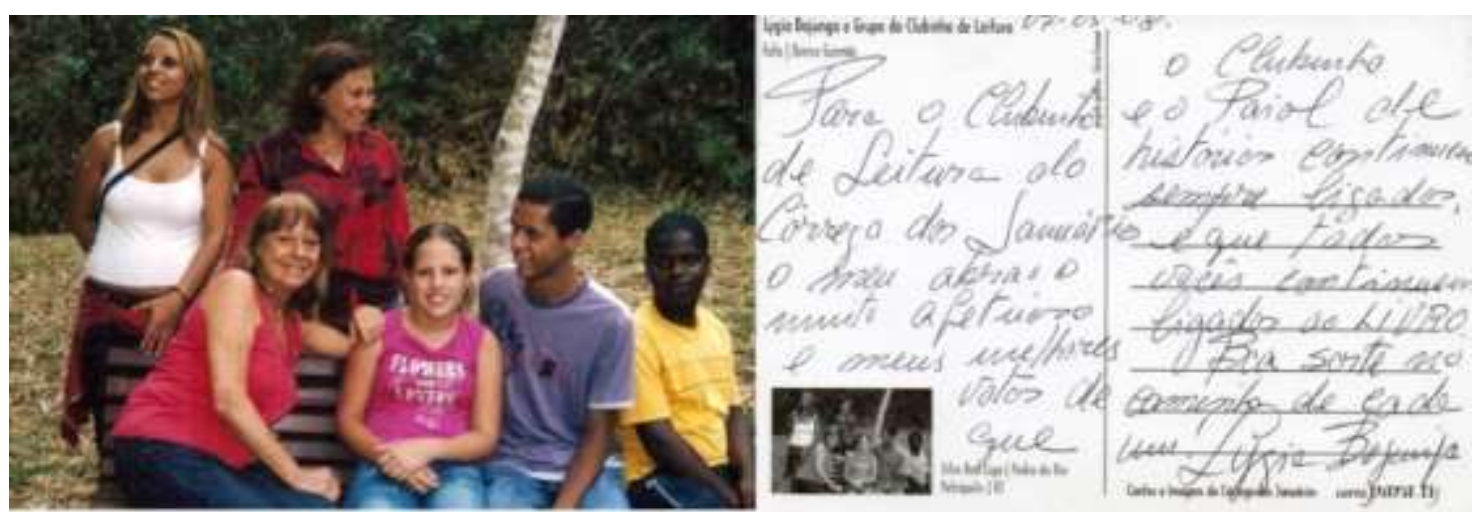

Figura 45: Postal enviado ao Clubinho pela escritora Lygia Bojunga. (2009, p. 236)

Para o Clubinho de Leitura do Córrego dos Januários o meu abraço muito afetuoso e meus melhores votos de que o Clubinho e o Paiol de histórias continuem sempre ligados, e que todos vocês continuem ligados ao livro. Boa sorte no caminho de cada um.

Lygia Bojunga 
Sonia Kramer, grande defensora do melhor aproveitamento do livro, do texto literário, em sala de aula e fora dela, nos conta como os livros a mobilizam, o que eu pude perceber em suas aulas quando ela fala com carinho do poder que um bom texto tem de "humanizar".
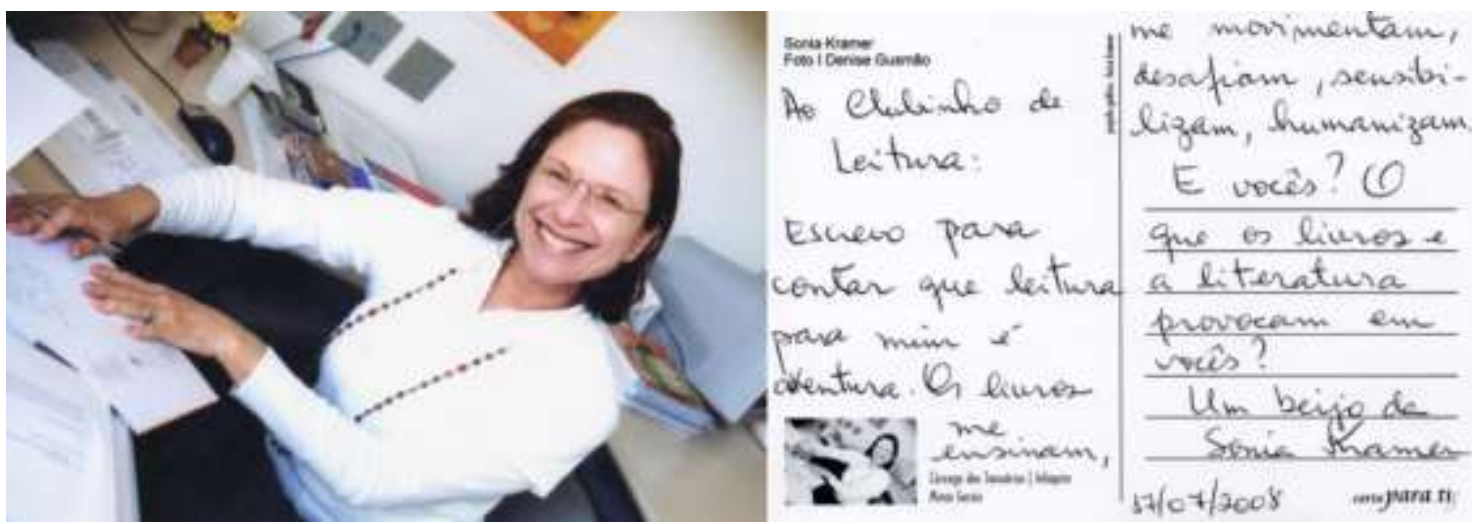

Figura 46: Postal de Sonia Kramer para o Clubinho (2009, p. 237)

Ao Clubinho de Leitura: Escrevo para contar que a leitura para mim é aventura. Os livros me ensinam, me movimentam, desafiam, sensibilizam, humanizam. E vocês? O que os livros e a literatura provocam em vocês? Um beijo da Sonia Kramer

Solange Jobim, professora do Departamento de Psicologia da PUC-Rio, nos escreve que, para ela, ler é abraçar o mundo com os olhos. Nos ensina que temos esse poder de trazer o mundo para muito perto de nós, diante dos nossos olhos, ao ler um livro.
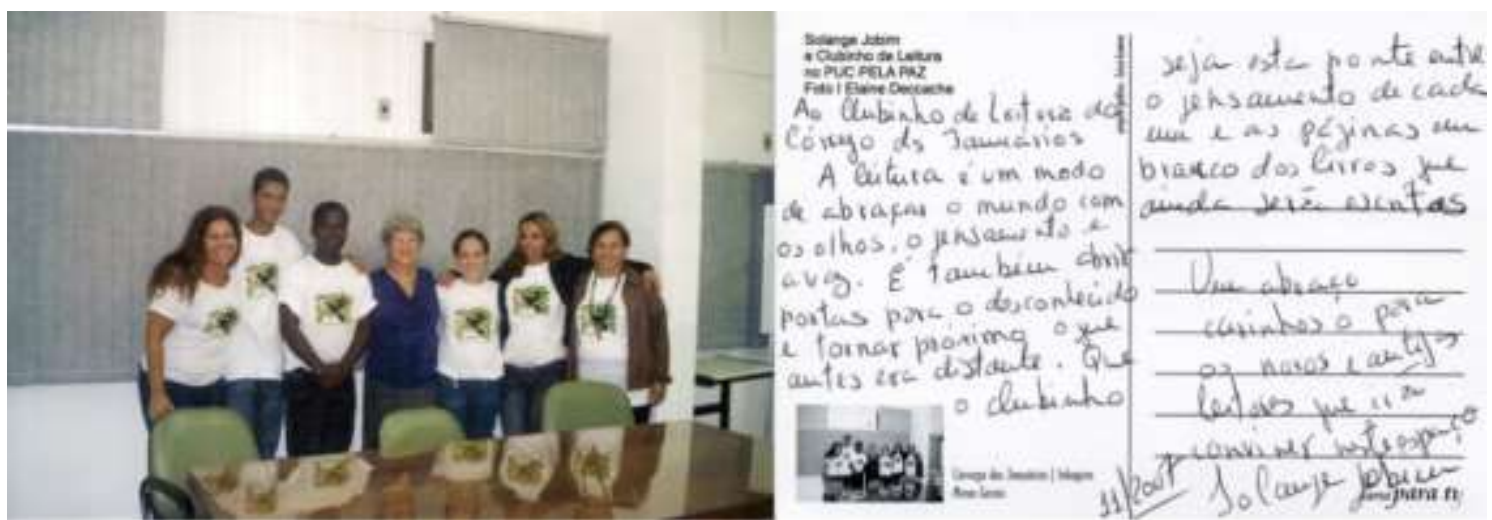

Figura 47: Mensagem de Solange Jobim. (2009, p. 137)

Ao Clubinho de Leitura do Córrego dos Januários,

A leitura é um modo de abraçar o mundo com os olhos, o pensamento e a voz. É também abrir portas para o desconhecido e tornar próximo o que antes era distante. Que o Clubinho de Leitura seja esta ponte entre o pensamento de cada um e as páginas em branco dos livros que ainda serão escritos. Um abraço carinhoso para os novos e antigos leitores que irão conviver neste espaço,

Solange Jobim 
Eliana Yunes nos conta que aprendeu a ler literatura com Monteiro Lobato, o pai da Narizinho, nos mostrando assim que cada um descobre ou é descoberto por um texto para se apaixonar e iniciar a grande viagem pelo mundo da literatura.
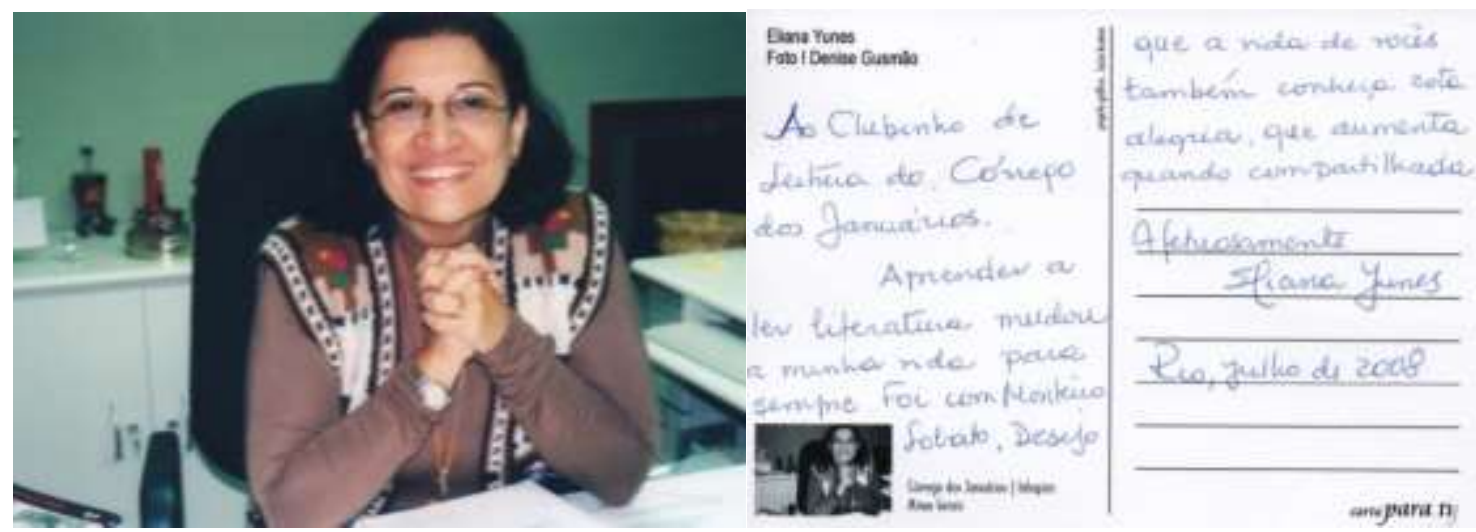

Figura 48: Mensagem/carta de Eliana Yunes

Ao Clubinho de Leitura do Córrego dos Januários:Aprender a ler literatura mudou a minha vida para sempre. Foi com Monteiro Lobato. Desejo que a vida de vocês também conheça esta alegria, que aumenta quando compartilhada.Afetuosamente. Eliana Yunes.Rio, julho de 2008

Esses cartões/mensagens compoem o painel que fica na sala do Clubinho, e estão ali para nos lembrar, nos colocar em contato com professores e escritores, e nos ajudar a entender a importância do nosso ato de ler, nos mostrando o valor de um livro. Quando recebemos estes cartões recebemos muito mais, construímos a grande rede de leitores, entramos na corrente das histórias que movem e comovem tanta gente vida afora. Quando nos escrevem reconhecem a nossa existência e nos engrandecem.

Essas atividades proporcionaram nosso encontro com diferentes culturas. Nossa história vencia as barreiras das montanhas de Minas e atingia pessoas de outros lugares que respondiam nossas cartas-postais ou que apenas olhavam as imagens. As pessoas se identificavam conosco e nós com elas. Esse foi um dos momentos em que nos reconhecemos parte de algo maior. Deixávamos de ser apenas a comunidade rural do Córrego dos Januários para sermos uma experiência de cultura a ser compartilhada. Nos sentimos valorizados naquilo que éramos. E nos sentíamos encorajados a organizar, junto com Denise, o espaço que abrigaria nossos contos e imagens. Fortalecida, toda a comunidade se empenhou na tarefa de criar nosso museu, a Casa de Memória e Cultura do Córrego dos Januários. 
Com esse espírito renovado, a Casa foi reformada e organizada pelas mãos da comunidade. O trabalho compreendeu, dentre as muitas ações, a reformulação do estatuto da Associação de Desenvolvimento Comunitário do Córrego dos Januários para que permitisse ações culturais, assumindo assim o papel legal junto à Casa de Memória e Cultura, a arrecadação de fundos através de serestas beneficentes, a obra de recuperação do imóvel, a confecção de rendados para compor os painéis da exposição; em tudo estavam também as nossas mãos. Os profissionais que foram do Rio de Janeiro levados por Denise se juntaram a nós em parceria, em construção conjunta, e essas ações reforçavam nosso sentido de comunidade, nos ajudavam a entender a necessidade daquele espaço, a reconhecer sua importância, e nos tornava a todos donos do novo momento que se instaurava.

\section{3 \\ O Clubinho de Leitura de sala nova!}

O Clubinho de Leitura ganhava finalmente sua sala. Nascia um espaço lúdico em que os livros estavam organizados, à altura dos olhos de seus donos. As crianças e adolescentes também ajudaram na criação da nova sede pintando o tecido das almofadas, nas fotografias, no painel que continha poemas, mensagens de escritores e crianças poetas. No cesto estavam livros de fotografias e a história da cidade ilustrada pelas crianças da Escola Municipal Elias Januário, a nossa escola. Tudo muito simples, mas com o nosso jeito, nosso olhar, e mais bonito do que havíamos imaginado.

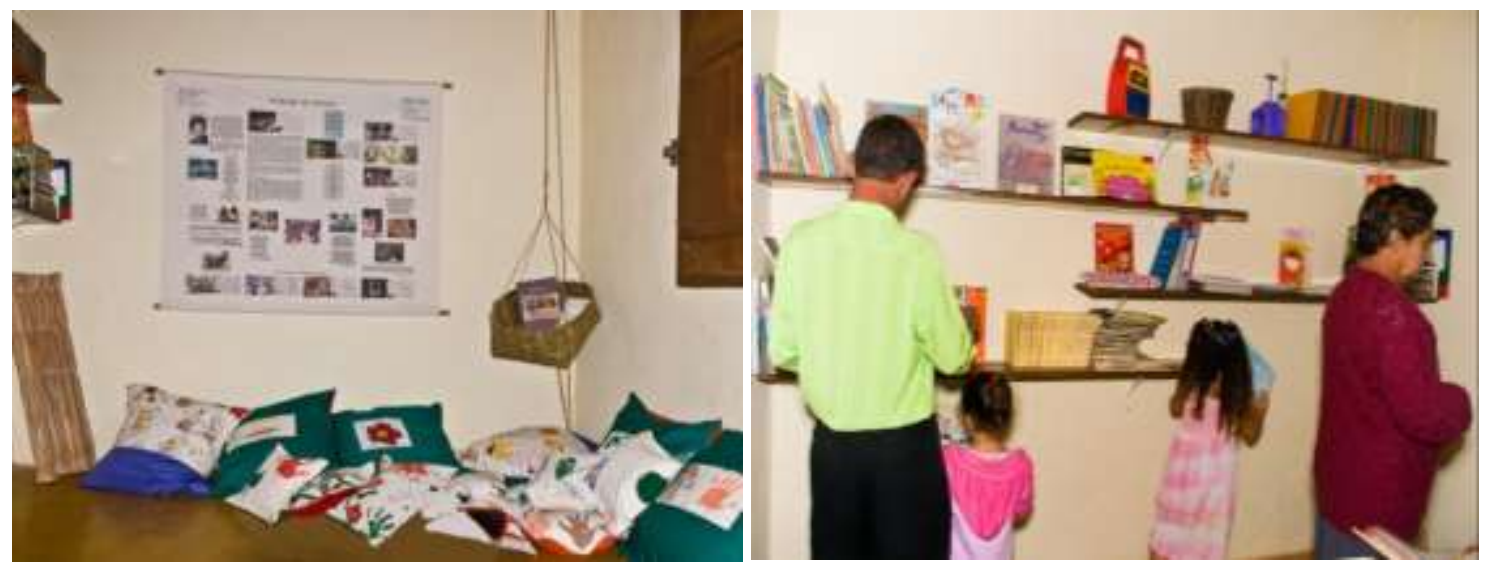

Figura 49: Sala do Clubinho no dia da inauguração

Figura 50: Primeiros visitantes do Clubinho (Fotos de Ana Andrade) 
Nossa história ganhava mais do que um abrigo, mas uma possibilidade de reconhecimento e de encontros. Nossas atividades regulares eram, e continuam sendo, as rodas de leitura aos sábados, no Clubinho, que são atividades de responsabilidade de Edervanio, Dayane, Rita, Edilaine e Branca que se revezam abrindo a casa aos sábados, realizando as leituras com os frequentadores. Edervanio faz parte do Clubinho desde que tinha 14 anos e Dayane, hoje com dezenove anos, desde os nove anos.

Dayane: Eu acho que por eu ser assim muito carinhosa com as pessoas que eu convivo e tudo, eu sempre pensei, eu sempre quis, eu sempre gostei de estar perto das pessoas assim, de estar junto e tal e, eu nem sei como, assim, parece que é como se tivesse sido uma coisa automática, eu entrar pra turma dos que frequentavam, na verdade em nem lembro como que foi assim o processo de quando eu passei de criança participante pra voluntária.

Edervanio: igual eu coloquei no início, eu acho que não teve assim: ah, a Dayane a partir de hoje é voluntária também. É algo que foi acontecendo.

A equipe foi se formando assim, com quem chegasse e se interessasse; algumas vezes por convite nosso para nos ajudar em situações específicas, mas que depois foram ficando. Sempre muito trabalho para poucas mãos, e quando Rita e Branca chegaram, e ficaram, para também colaborar, ganhamos fôlego. Edilaine foi se aproximando, se integrando um tempo depois, e juntos formamos uma equipe que vai além das expectativas. Neste momento, logo depois da inauguração, José do Carmo, lavrador, cuidava de manter o quintal e os arredores da Casa limpos e Adélia Pereira estava sempre presente quando necessitávamos, e hoje continua sendo assim. Esta é a equipe que, com a participação também de suas famílias, fica à frente dos trabalhos, e a comunidade colabora das mais diversas formas.

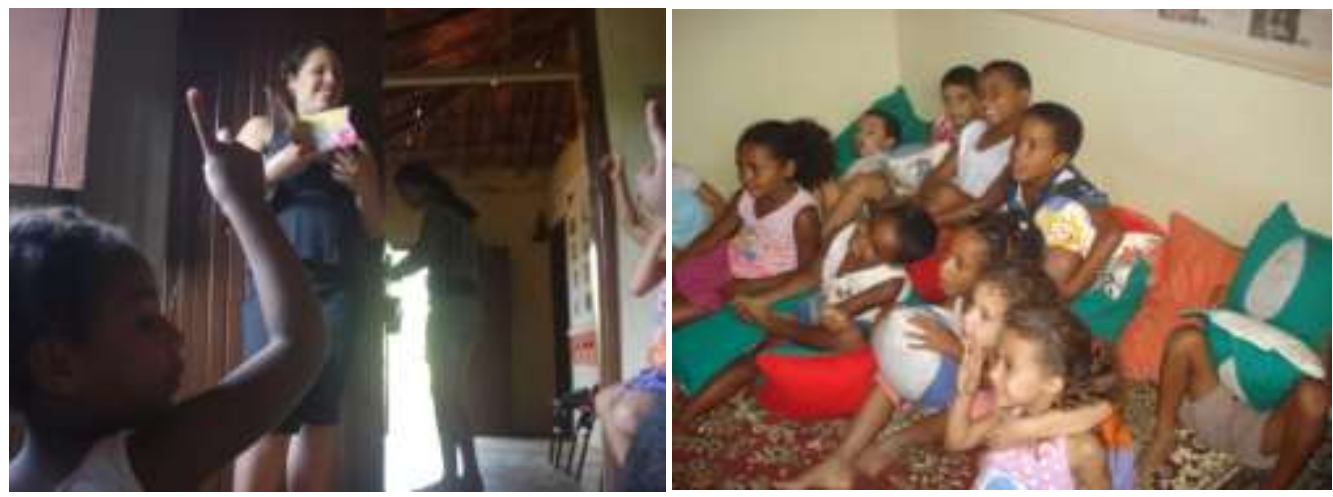

Figura 51: Dayane lendo para as crianças

Figura 52: Crianças ouvindo a história de Dayane (Fotos de Sávio) 
Dayane lê para os que agora têm a idade que tinha quando começamos. O trabalho prossegue, outros meninos vão chegando e outras leituras vão acontecendo...

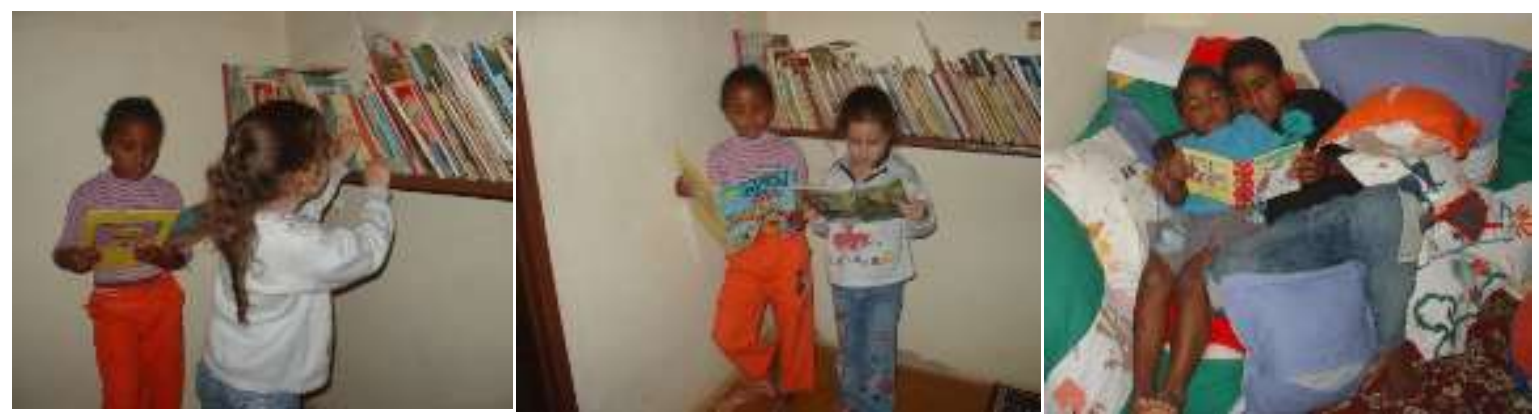

Figura 53: Maria Eduarda e Sara 1

Figura 54: Maria Eduarda e Sara 2

Figura 55: Caio e Sandro lendo no Clubinho

\subsection{1}

\section{Temos visita!}

Essa casa com as portas sempre abertas às visitas teve a alegria de receber algumas pessoas que mais do que nos visitar foram, generosamente, levar sua arte, seu saber e compartilhar conosco. Foram encontros memoráveis.

Um desses encontros foi com o grupo Teatro Circense Andança, de Petrópolis, que tem um extenso trabalho realizado na região de Petrópolis e em muitas andanças pelo Brasil e além fronteiras. O diretor Madson José apresenta o grupo.

Teatro Circense Andança: O grupo foi criado em 1993, na cidade de Petrópolis/RJ.

Seu trabalho é caracterizado pela pesquisa constante das linguagens teatrais e circenses, pela relação perene com a cultura popular, pela utilização do fazer artístico como instrumento pedagógico em processos de formação diversos, pela manutenção contínua de intercâmbio com pessoas, grupos ou instituições, pela utilização de espaços tradicionalmente não considerados para a realização de seus espetáculos e outras atividades, pela manutenção de um repertório de espetáculos, pela priorização de uma visão ecológica na viabilização do seu trabalho, pela valorização da dimensão coletiva na condução do seu fazer, pela manutenção contínua de espaços de formação de adolescentes e jovens, principalmente em situação de risco, pela gradativa viabilização de geração de trabalho e renda para os mesmos e pelo contato perene com organizações que realizam atividades formativas diversas de perspectiva sócio-culturais.

Seu núcleo de trabalho é formado por um pequeno grupo de atores, palhaços e arteeducadores que, além de participarem dos projetos específicos do grupo, atuam também em propostas de outras organizações. 
Nos conhecíamos através do contato com o Paiol de Histórias, projeto da Fundação Casa Lygia Bojunga, ainda durante a pesquisa de Denise. Em 2010 o grupo me escreveu dizendo que estavam gestando uma nova peça e gostariam de passar uns dias no Córrego dos Januários fazendo sua pesquisa, laboratório para a preparação da peça teatral "Depois da Chuva"'. A solicitação por parte do grupo nos encheu de alegria, pois dentre suas atividades a serem desenvolvidas no Córrego dos Januários, estavam previstas a apresentação de "A Velhota Cambalhota", personagem do livro de Silvia Orthof, visita à escola com os palhaços Cacareco e Marmelada e cantoria convocando os violeiros locais a tomarem parte. A chegada deles mobilizou a comunidade. Hospedados na casa de Joversino e fazendo as refeições cada dia em uma casa, se integraram aos moradores e cativaram a todos. Pela primeira vez recebíamos artistas profissionais que nos mostraram lindos espetáculos e nos levaram alegria.

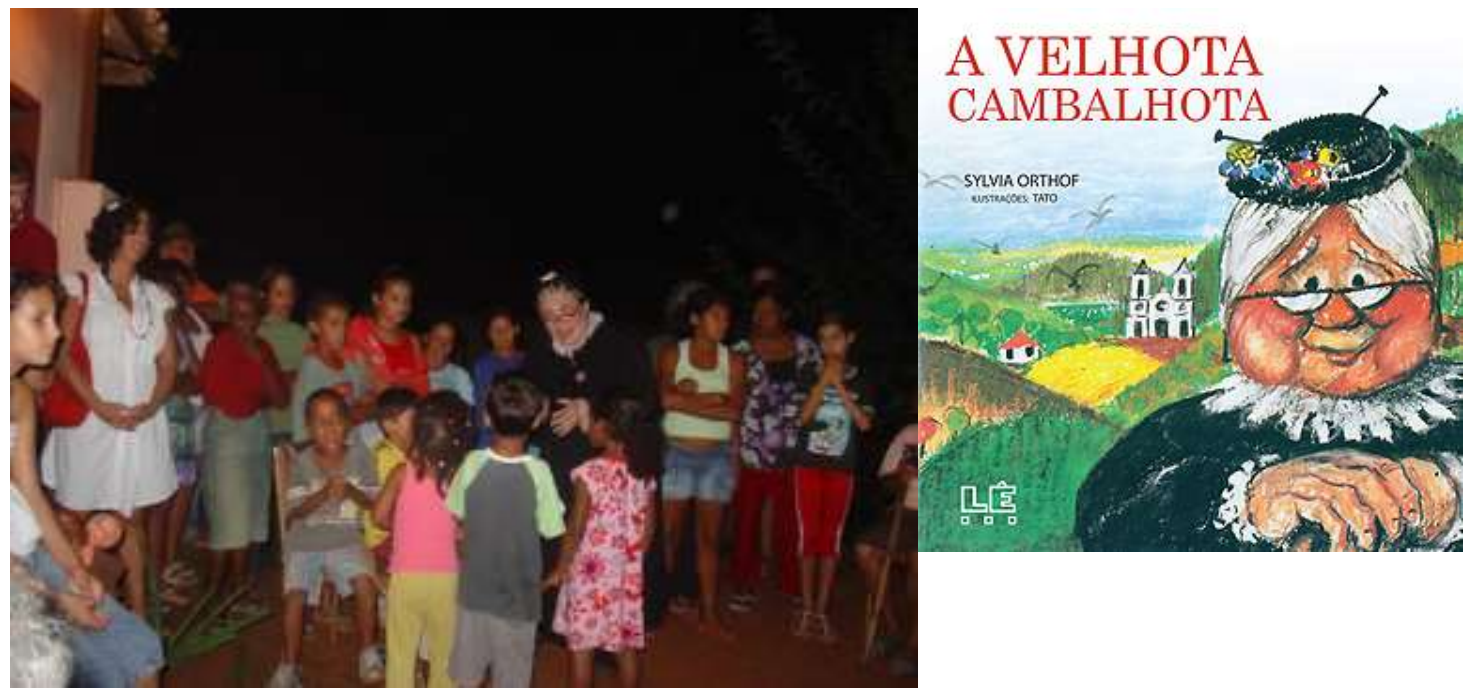

Figura 56: A Velhota Cambalhota na Casa de Memória e Cultura

Tanta proximidade favorece a desmistificação do artista, coloca a ação de criar, de imaginar nas mãos de todos e as reações são as mais diversas. Mais do que a arte de representar, eu diria que nos emociona a arte da presença. Maria Aparecida, professora da escola da comunidade e mãe de Jamile e João Laender,

9 -O espetáculo "Depois da chuva ganhou os seguintes prêmios:”Melhor espetáculo adulto; melhor cenário; melhor direção; melhor figurino; melhores atrizes; melhor trilha sonora; melhor iluminação no IV PROFEST - Festival Nacional de Teatro de Congonhas/MG.

-Prêmio Maestro Guerra Peixe 2012 na categoria teatro pela Direção de Arte de Raquel Theo em Petrópolis/RJ. 
frequentadores do Clubinho, nos conta o seu olhar para o trabalho dos petropolitanos.

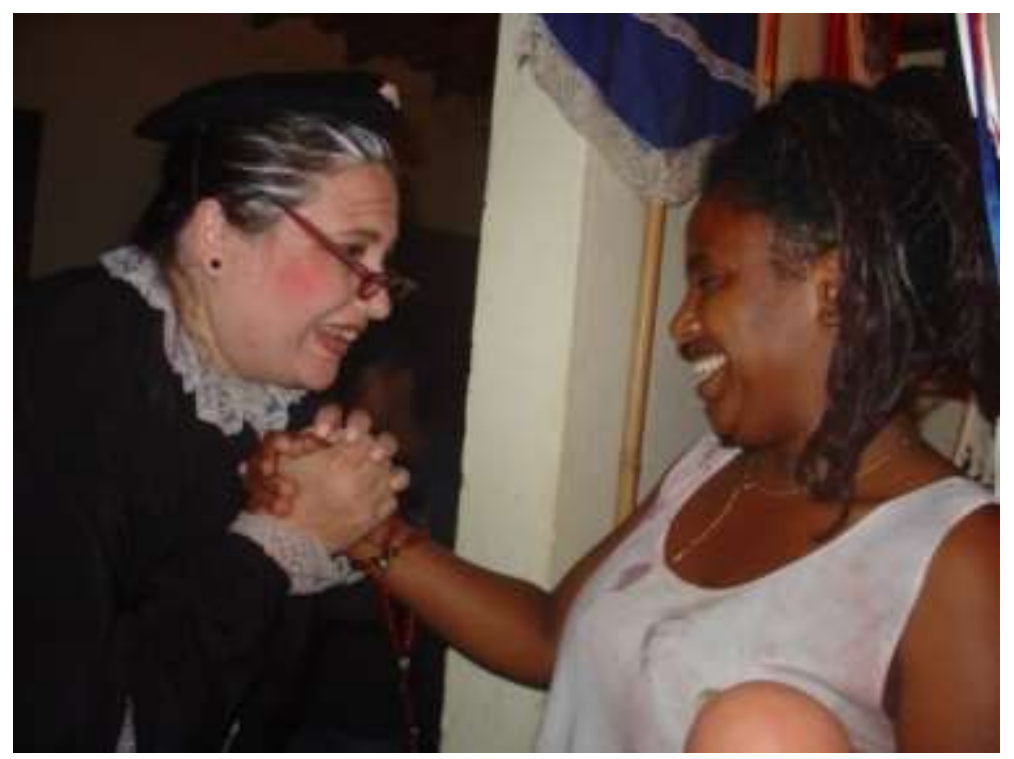

Figura 57: A Velhota Cambalhota e Maria Aparecida, na Casa de Memória e Cultura

Maria Aparecida: eu acho assim, que eles trazem muita novidade. Então aquele pessoal, de Petrópolis, eu acho que eles trazem muita coisa nova. Eles são criativos, entendeu? Eles são criativos, eles criam, não sei. Eu acho interessante. As historinhas que eles criam, os teatros que eles montam pra apresentar, eu acho interessante. Eu acho muito bonito.

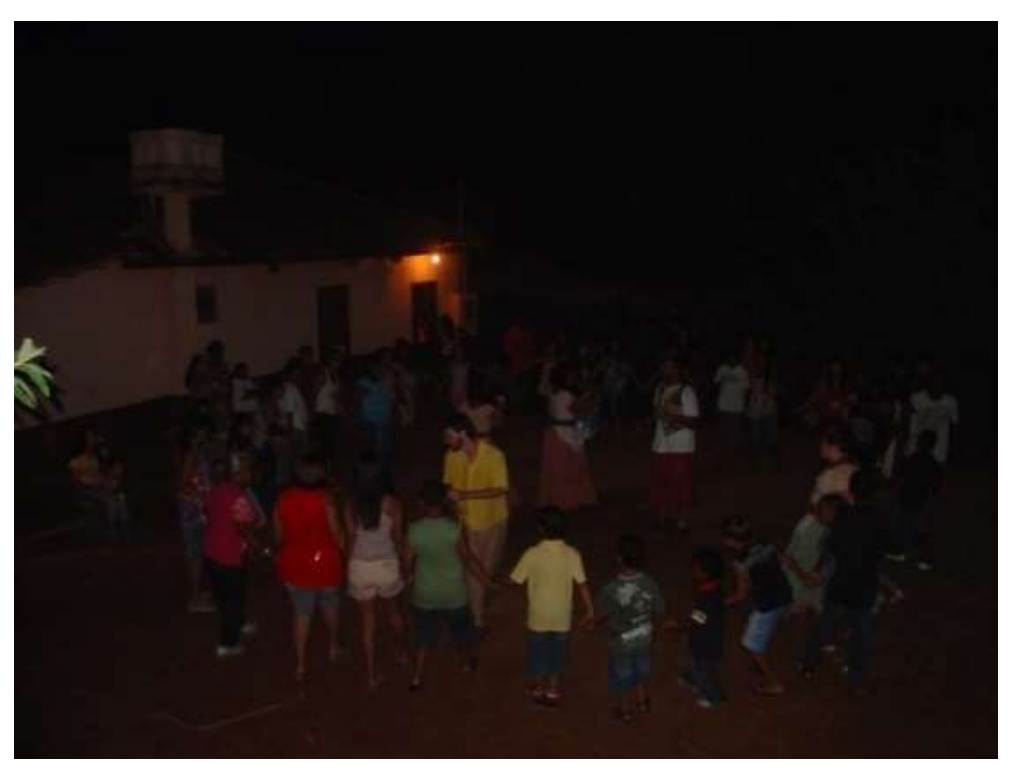

Figura 58: Olha a ciranda... 

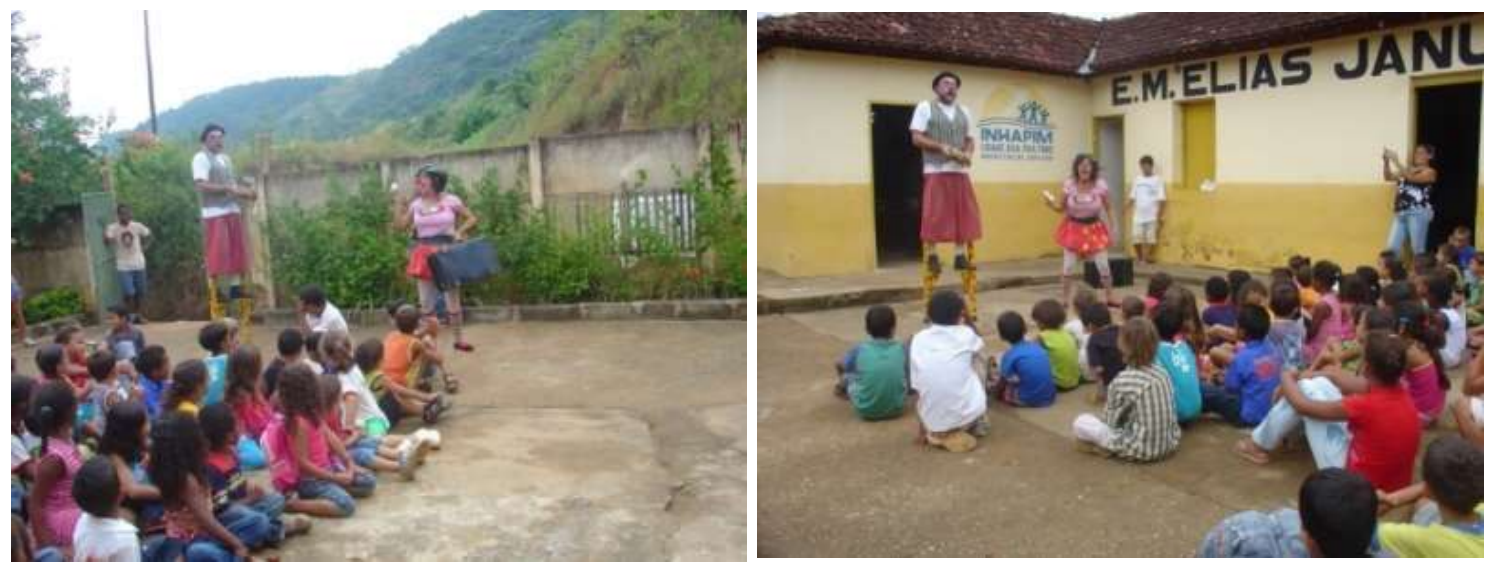

Figura 59: Hoje tem palhaçada, tem sim senhor!

Figura 60: Na Escola Municipal Elias Januário!!!

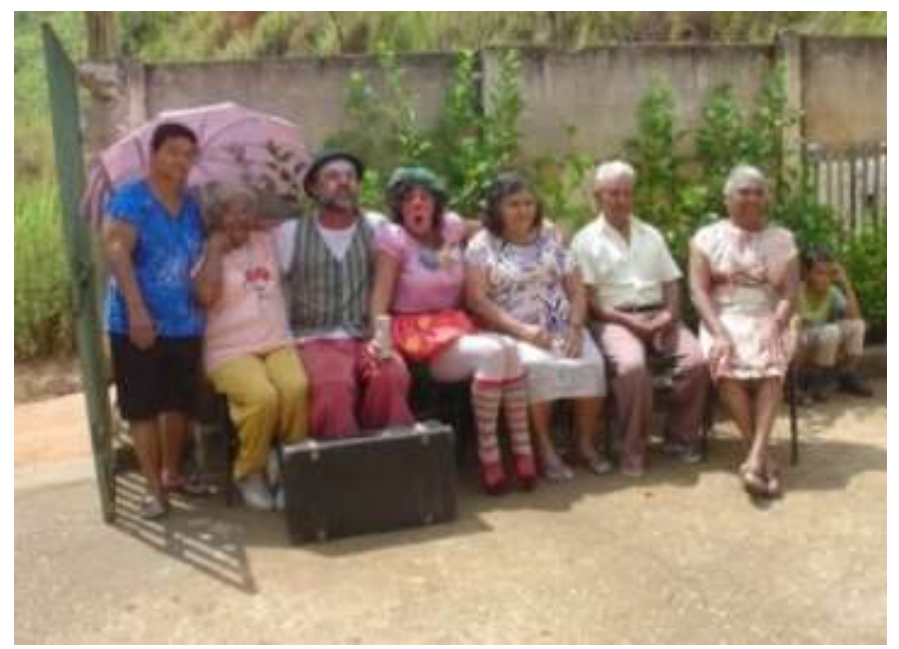

Figura 61: Nenê, Adriana, Cacareco, Marmelada, Mariinha, Zito e Zilmar, todos vão à escola...

A estadia do grupo no Córrego dos Januários nos proporcionou muitos aprendizados. Acompanhávamos, curiosos, suas andanças pelo Córrego. Como nossa comunidade poderia inspirá-los, ajudá-los a compor uma peça de teatro? $\mathrm{O}$ que tínhamos ali que podia ser aproveitado em arte? O grupo visitava moradores, reparava nos animais, fotografava pessoas, plantas, sementes, bichos e conversava muito com muita gente, principalmente com as crianças. Thiago, um dos adolescentes, depois de acompanhá-los, conversar com eles e ajudar no que fosse necessário, disse que havia pensado em muitas coisas, mas que agora achava que queria mesmo era de ser palhaço, e perguntava tudo ao Madson, o palhaço Cacareco e diretor do grupo. A casa onde estavam hospedados ficava sempre cheia de gente, e eles foram sempre muito atenciosos. 
Em 2011, quando estrearam a peça no Teatro D. Pedro, em Petrópolis-RJ, eu tive a felicidade de estar presente. Qual não foi minha surpresa e emoção ao ver na entrada do teatro, junto ao retrato do ilustre Imperador D. Pedro, uma exposição com as fotos de muitos januarenses. Uma retrospectiva da passagem dos artistas pelo nosso Córrego dos Januários. Nossa história, nossa gente viajava em nome da arte por mãos de artistas.

Em 2012 foi a vez do Teatro Circense Andança chegar a Ipatinga, cidade perto de Inhapim, com a peça "Depois da Chuva”, e lá fomos nós. Alugamos um ônibus e fomos ao teatro. Estávamos todos ansiosos, os artistas e a plateia, pois era o momento de pessoas que nunca tinham ido ao teatro terem uma primeira experiência. E nós, de certa forma, estávamos presentes no palco, situação mais do que especial. Não seria tão especial se nós da comunidade tivéssemos apenas recebido um grupo de pessoas em busca de informações que os ajudasse a criar suas peças teatrais, fazerem suas experiências in loco e depois voltarem para suas metrópoles, mas conosco e os amigos artistas havia o entendimento de que as experiências deviam ser compartilhadas, e isso era o que nos fazia a todos muito especiais. 


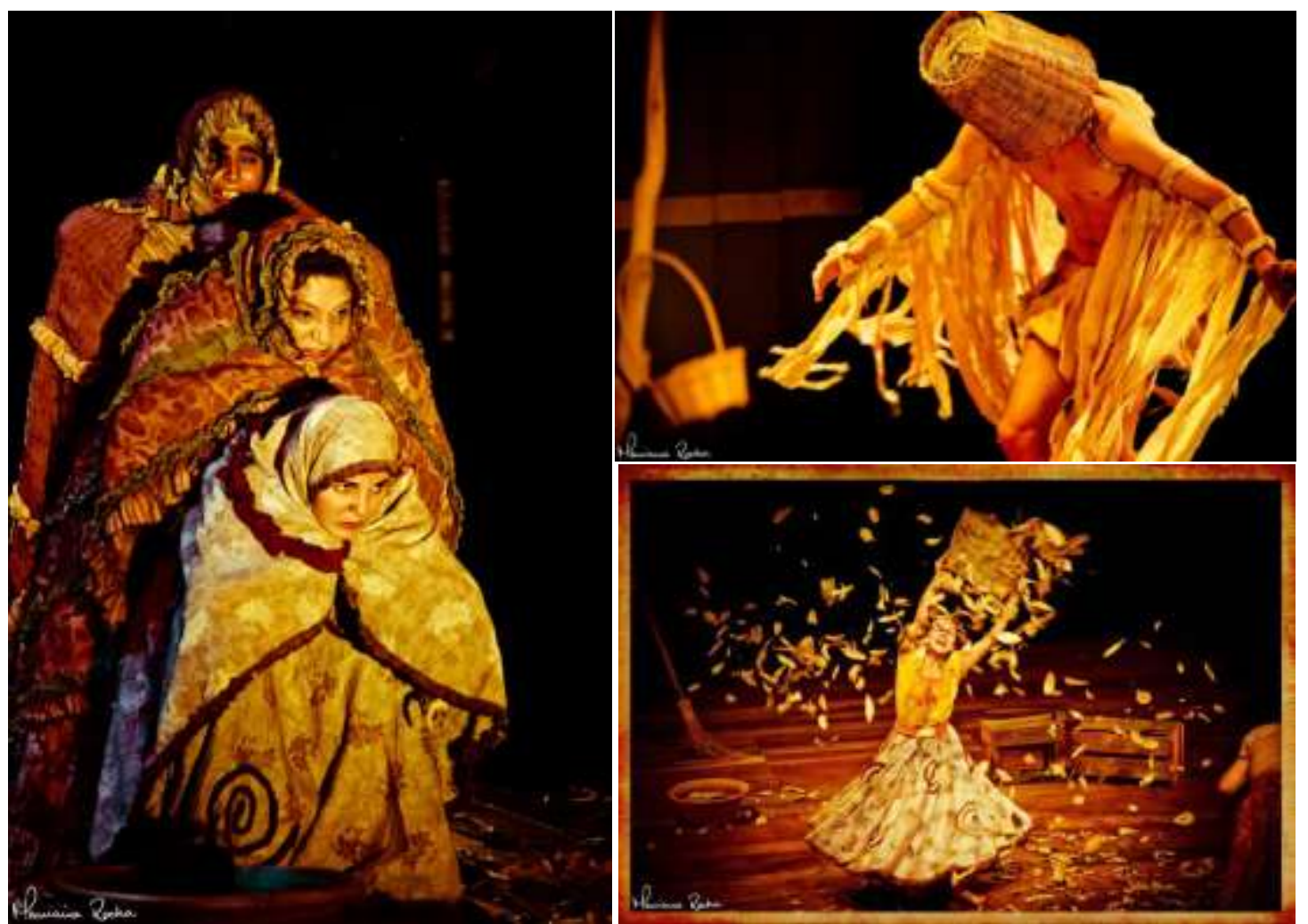

Figura 62: Espetáculo "Depois da Chuva" 1 (foto de Mariana Rocha) Figura 63: Espetáculo "Depois da Chuva” 2 (foto de Mariana Rocha) Figura 64: Espetáculo "Depois da Chuva" 3 (foto de Mariana Rocha)

Fomos inspiração para cenas e cenários, e o grupo, que trabalha com a nobreza do gesto, dos movimentos, dos sons e dispensa as palavras, havia me contado, quando da estreia no Teatro D. Pedro, que estavam ansiosos para verem nossa reação ao ver um pouco do Córrego dos Januários na forma como o representavam.

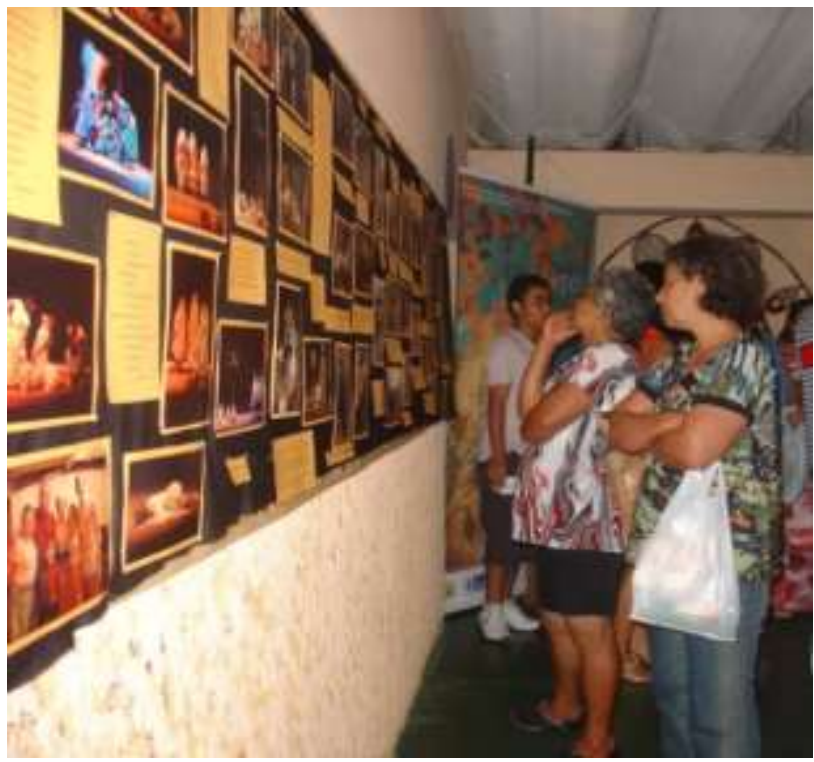

Figura 65: Fomos ao teatro! Jupira, Adélia e Gustavo 
Sempre que temos a experiência de receber visita ou de visitarmos algum lugar ou pessoa, fazemos questão de um momento de conversa, de troca de ideias sobre o que estamos vivenciando, pensarmos juntos o que nos acontece e o que isso pode nos acrescentar como impulso para novas ideias. Tudo é sempre muito novo. Diferente de quem é criado nas grandes cidades, imerso no mundo da cultura, seja o livro, o cinema, o teatro e outros espaços onde está mais disponível o contato com manifestações culturais em geral, estamos no processo de reconhecimento do valor da nossa cultura, de nos sentirmos parte de um universo maior, e de que temos muito o que intercambiar nesses processos de lida com o mundo para além das montanhas que cerca o Córrego dos Januários, e que tanto caracteriza a nossa Minas Gerais. Madson, Renata, Luiza, Laércio e Rose, os Andança, sempre nos abriam os braços e nos acolhiam, nos convidavam à troca de saberes, de olhares, de experiências muito peculiares, e isso era recíproco. Durante a conversa proporcionada depois do espetáculo ali no saguão do teatro, sentados no chão, num desejo de abrir um campo de entendimento entre atores e plateia, Dulcinéia, professora, falou de sua emoção ao sentir o Córrego dos Januários representado em gestos, destacava os momentos em que percebeu mais claramente o traslado do que nossa comunidade vive no cotidiano para o espaço do palco: o cantar do galo, o cacarejar das galinhas, o movimento de moer a cana e o café, no varrer a casa cantando a "toada" de um versinho que era nossa cantiga de roda, Dulcinéia externava sua alegria em se sentir representada. 

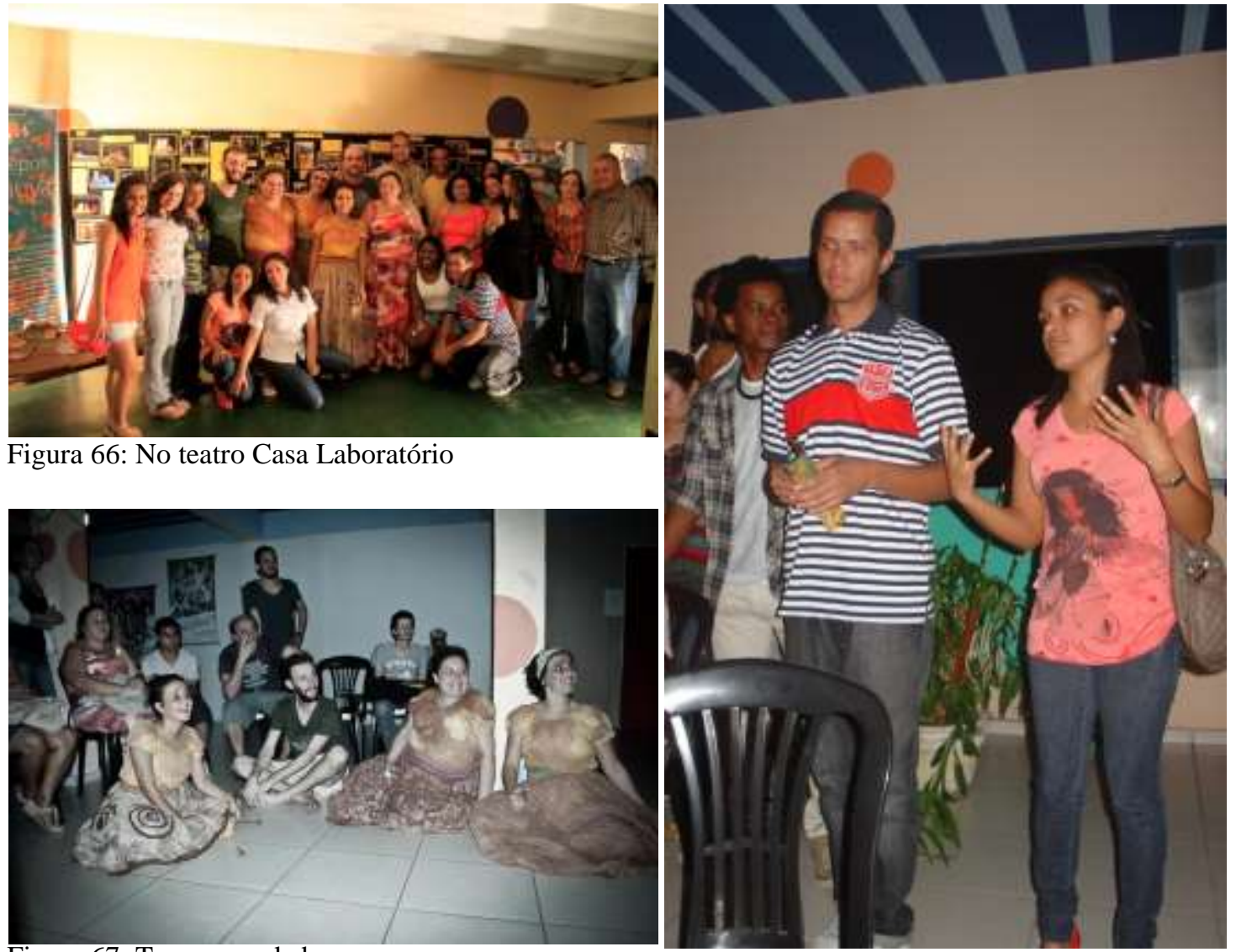

Figura 66: No teatro Casa Laboratório

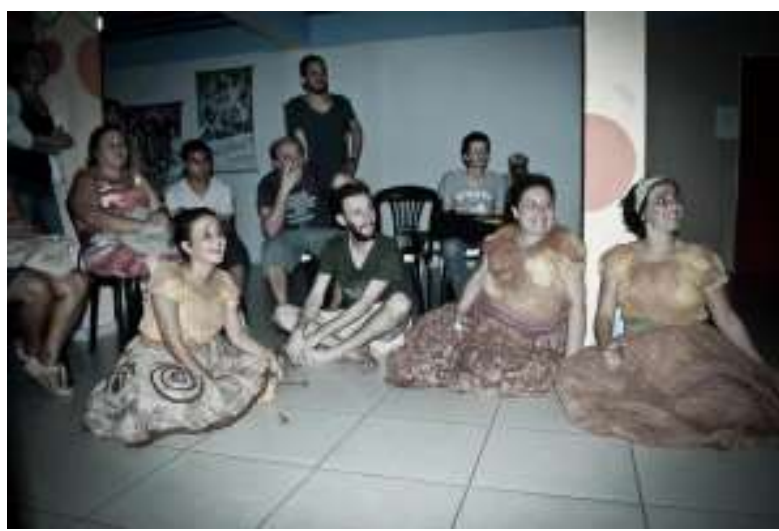

Figura 67: Tem prosa da boa.

Figura 68: Dulcinéia conta sua experiência...

Depois das apresentações em Ipatinga o grupo de atores foi para o Córrego dos Januários. Hospedados na casa de Edervanio, nos proporcionaram três dias de convívio irmanados no trabalho de lidar com arte, e nos presentearam com o espetáculo "Direções do Céu" 10 ", e a segunda visita tão aguardada da "Velhota Cambalhota". Dois dias em que a Casa de Memória respirou alegria, movimento, aprendizados.

Bom ter a casa cheia. Era lindo ver os rostos das pessoas iluminados diante do espetáculo, sob um céu salpicado de estrelas depois de muitos dias de chuva. $\mathrm{O}$ nosso terreiro ficou tomado de expectadores. Lembro que a hora do espetáculo ia chegando e nós não tínhamos cadeiras além das vinte cadeirinhas infantis. Preocupados com os idosos e as mulheres com crianças de colo nós buscamos bancos na casa dos vizinhos, ajeitamos o que foi possível, mas na hora que vimos

10 - O espetáculo "Direções do Céu” recebeu os seguintes prêmios:

- Melhor espetáculo de rua; melhor maquiagem; melhor atriz coadjuvante e melhor direção no IV PROFEST - Festival Nacional de Teatro de Congonhas/MG.

- Melhor espetáculo infantil; melhores atrizes e melhor espetáculo pelo júri popular no $6^{\circ}$ Festival Nacional de Juiz de Fora. 
gente e mais gente chegando nós corremos na casa do vizinho e pedimos as cadeiras que tinham alugado para o casamento no dia anterior, e eles nos cederam cerca de cem cadeiras, o que nos permitiu acomodar grande parte do público. E tem sido assim há treze anos, desde que meus amigos me acompanharam na primeira viagem, há por parte de toda a equipe que está à frente das atividades a certeza de que na hora tudo dá certo.
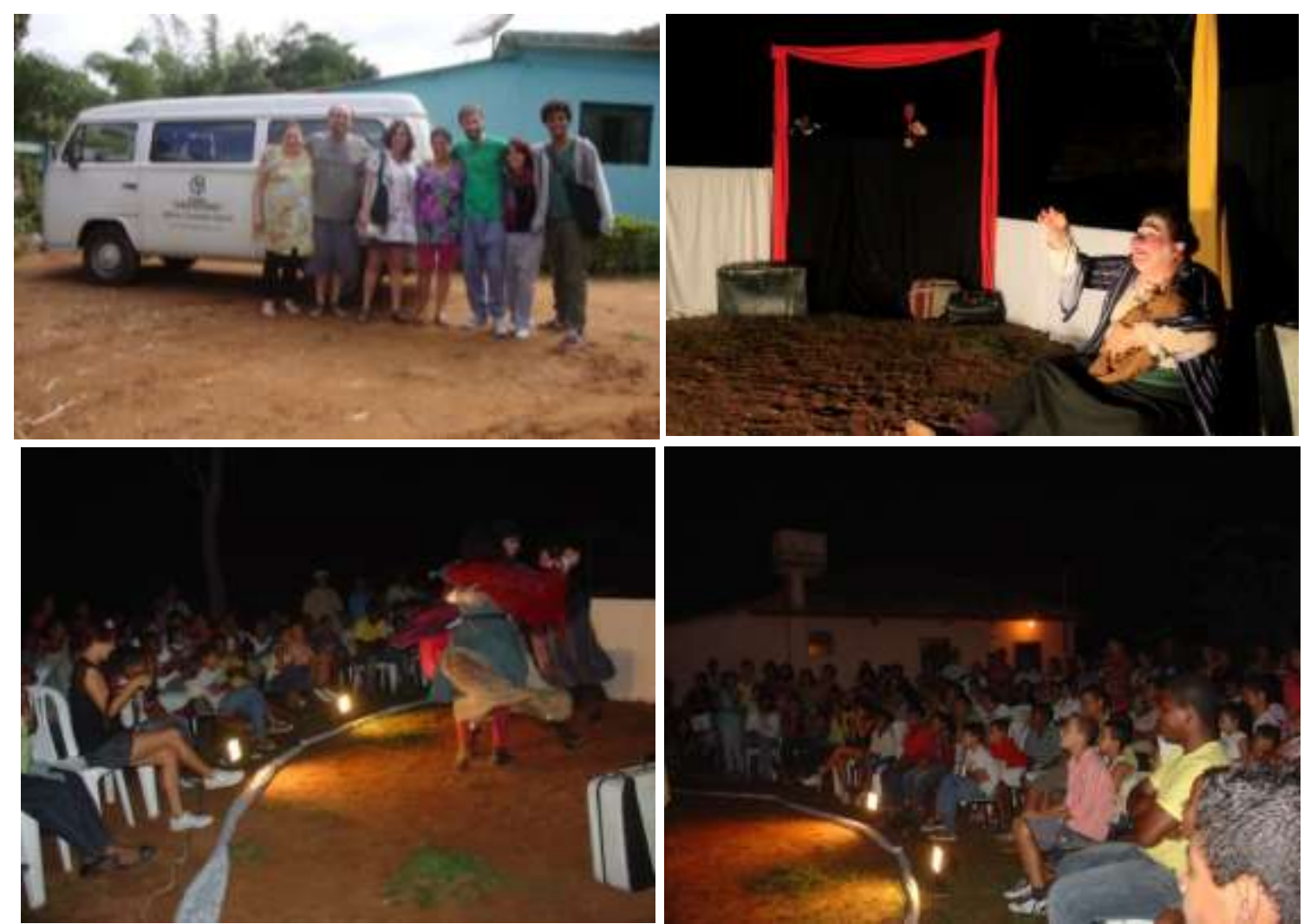

Figura 69: Os amigos do Andança na casa de Edervanio

Figura 70: Espetáculo "Direções do Céu” na Casa de Memória de Cultura 1 (Foto de Luisa Alves) Figura 71: Espetáculo "Direções do Céu” na Casa de Memória de Cultura 2 Figura 72: Espetáculo "Direções do Céu” na Casa de Memória de Cultura 3

Das artes do palco para os trabalhos manuais, alguns meses depois fomos agraciados com uma oficina de cartões ecológicos com os meninos da ONG "Filhos da Terra", também de Petrópolis, que fazem parte do Centro de Defesa dos Direitos Humanos de Petrópolis, e são um Ponto de Cultura ${ }^{11}$. Numa delicada

\footnotetext{
${ }^{11}$ Ponto de Cultura é a referência de uma rede horizontal de articulação, recepção e disseminação de iniciativas culturais. Como um parceiro na relação entre estado e sociedade, e dentro da rede, o Ponto de Cultura agrega agentes culturais que articulam e impulsionam um conjunto de ações em suas comunidades, e destas entre si. (Fonte: http://www2.cultura.gov.br/culturaviva/ponto-decultura/ )
} 
relação com materiais extraídos da natureza levaram para a nossa Casa um novo olhar sensibilizando para a beleza da arte da simplicidade e do cuidado.

\section{Projetos - Filhos da Terra}

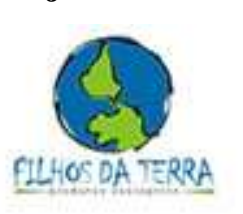

O grupo "Filhos da terra" é uma iniciativa do Centro de Defesa dos Direitos Humanos de Petrópolis, que acredita na importância de se conjugar a educação à arte e à ecologia como formas alternativas de se gerar trabalho e renda. Mas nossa proposta não para por aí. Mais do que gerar produtos, estamos empenhados em fomentar novas consciências e lógicas mais ecológicas, éticas e inclusivas. Por isso, nos espelhamos nos princípios de sustentabilidade ecológica sugerida pelo documento "A Carta da Terra", que já se tornou até oficina de assessoria. O grupo agora foi contemplado com o projeto Ponto do de Cultura, iniciativa do Governo que tende a fomentar as diversas formas de cultura. Os resultados já são muitos, sobretudo em termos de novas consciências e de esperança. O grupo exporta seus trabalhos para vários países, como Suécia, Itália, Espanha, Suíça, Irlanda e Canadá. (Fonte: http://www.cddh.org.br/terra.html )

O trabalho levado por esses meninos despertam consciência, e com isso o olhar vai sendo treinado para perceber sutilezas que Maria Aparecida ressalta a importância.

Maria Aparacida: Igual, eu acho bacana assim essas pessoas que vocês enviam pra comunidade, né, de outra comunidade pra vir fazer o trabalho com eles. Igual veio aquela menina, que ensinou fazer uns desenhos bonitos, um trabalho bonito na casca de alho. Na casca de alho, com conchinha do mar. Um trabalho simples, com material simples, e muito gratificante.

Toquinha: ah, com os cartões, da oficina dos cartões.

Maria Aparacida: ah, ela veio na minha casa mas eu não gravei o nome dela.

Toquinha: ah, e aí você acha que estes trabalhos, pras suas crianças, ajuda no desenvolvimento escolar também?

Maria Aparacida: Ajuda. A criança fica criativa, Igual, eles chegaram aqui com o trabalho, assim, eu achei muito interessante, feito com casca de alho, assim, aquela coisa mais simples, um material simples que a gente às vezes tem dentro de casa e eles utilizaram com eles lá no Clubinho. Ficou aquele trabalho maravilhoso.

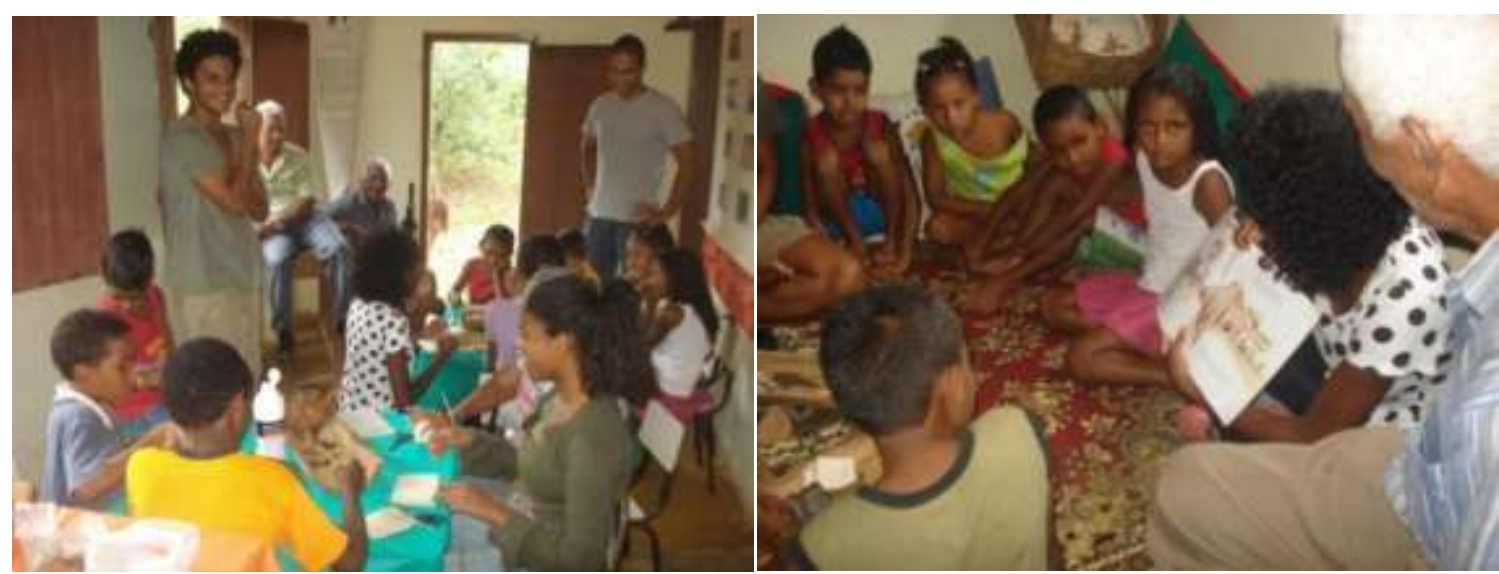

Figura 73: Oficina de cartões ecológicos 
De materiais reciclados e produtos disponíveis na natureza, como fiapos de penas, pedrinhas, areia, pigmentos naturais, cascas de ovos, pétalas de flores, folhas secas, gravetos e bambu os participantes do Projeto Filhos da Terra fazem Arte; Arte com "A" maiúsculo, pois é uma verdadeira expressão do belo, de sentimentos e de resgate de vivências já há muito esquecidas pela sociedade e que encantam ao primeiro olhar.

Os jovens confeccionam papel reciclado e produtos ecológicos, tais como cartões, quadros, luminárias e móbiles, utilizando como matéria-prima apenas elementos reaproveitáveis. A utilização destes materiais criam um vinculo muito grande entre a natureza e o homem, além de ser uma opção de fonte de renda ecologicamente correta, algo muito raro nos dias de hoje. A percepção e os sentimentos são palavras chave para a realização dos trabalhos.

"A partir do trabalho que eu vim fazer aqui você percebe mais o meio que você vive, a quantidade de cores que se tem. Cada casca de cebola é diferente... Você olha para os morros da cidade e percebe o quão diferente e o quão bonito é..." (jovem participante do projeto)

A casca de alho vira um vestido esvoaçante, enquanto folhas secas, areia e musgo compõem a paisagem que mais parece um poema. (Fonte: http://www.flickr.com/photos/simonesattler/4709251271/ )

Aparecida fala em criatividade, em espaço para o exercício do criar dentro do Clubinho de Leitura, que reflete no rendimento escolar. São novos modos de ler, novas possibilidades de perceber o entorno, outra maneira de lidar com o cotidiano. A oficina teve início com a leitura do livro Guilherme Augusto Araujo Fernandes (FOX, 1995), e quando uma oficina de cartões ecológicos tem início com a leitura de um livro em que a história fala da relação entre uma criança e os moradores de um asilo e que neste momento de leitura estão presentes pessoas de todas as idades, a conversa e o trabalho que vem após a experiência da leitura são, no meu entendimento, mais aprofundados, não precisa explicação. Esses movimentos de experimentação do novo, de partilha de experiência, nos permite respirar como quem vem à flor d'água buscar oxigênio, e nos descobrirmos entendendo a potência dos encontros, dos trabalhos em grupo.

Todas as dificuldades que temos para levar adiante nosso projeto, desde a falta de pessoal, de recursos financeiros e muitas vezes do espaço adequado para determinadas atividades, vêm sendo superadas por essas descobertas, por pessoas que nos enxergam, que também buscam novos lugares por onde mostrar sua arte, que nos ensinam o valor das pequenas coisas. E é sempre via de mão dupla, pois cada parte oferece o que tem e pode oferecer. E nesse espaço de troca afloram possibilidades, nascem parcerias, brotam ideias de trabalhos conjuntos, de fazer 
crescer a rede, de expandir conhecimentos. Assim tem sido, e desejamos que assim seja.

Uma das nossas prioridades nas atividades da Casa é que todas as faixas etárias possam trabalhar juntas, participar das mais variadas atividades num mesmo momento.

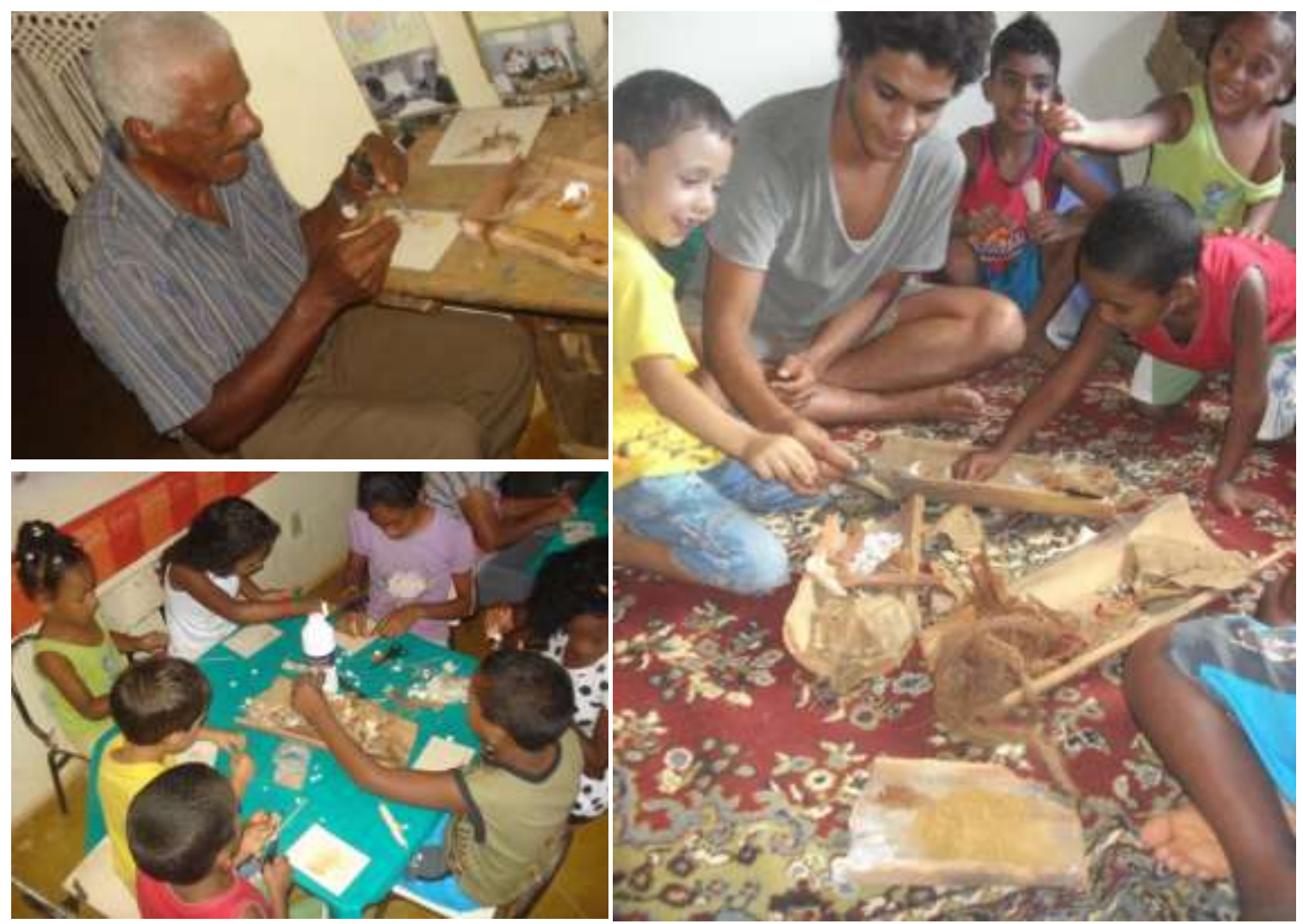

Figura 74: Oficina de cartões ecológicos 1

Figura 75: Oficina de cartões ecológicos 2

Figura 76: Oficina de cartões ecológicos 3 (Fotos de Sávio)

O Clubinho é um espaço multidisciplinar onde a leitura é a mola mestra, mas junto vêm todas as artes, e são todas muito desejadas e bem-vindas, se complementam. Todos os interessados encontram uma cadeira, uma almofada, um lugarzinho no tapete para sentar, ou mesmo um olhar através da janela, e sentir-se em casa. E sempre tem um cafezinho na cozinha. 


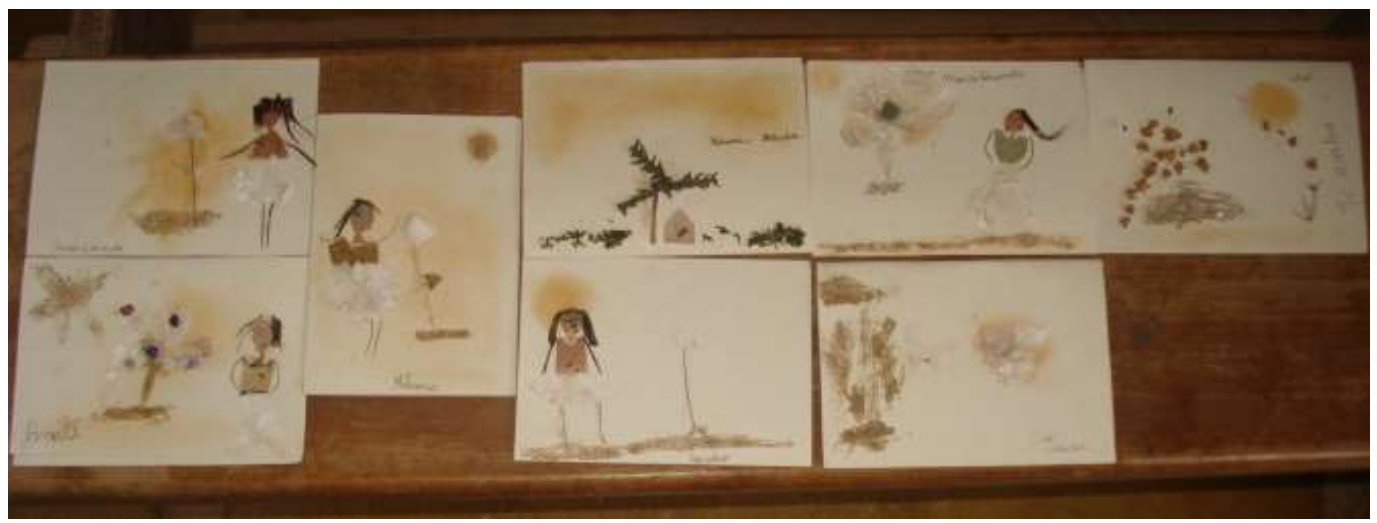

Figura 77: Oficina de cartões ecológicos 4 (Foto de Sávio)

O ano de 2013 ainda nos reservava um novo cruzamento de histórias, agora tendo a música como motivador do encontro.

Durante nossa ida ao teatro fizemos contato com Saulo Guedes, neto de Seu Zé Barba, músico com trabalhos reconhecidos na região do Vale do Aço-MG e com inserção em projetos sociais na região de Ipatinga e Coronel Fabriciano. Por caprichos do destino, Saulo foi convidado por amigos de Petrópolis, via internet , para a apresentação do grupo Teatro Circense Andança.

Saulo: foi o Guto, que toca no Taruira, mandou uma mensagem falando: vai ver, ajuda a divulgar aí em Ipatinga, que o pessoal do Andança são grandes amigos nossos aqui, vale a pena conferir. Falei: vou assistir. Aí eu divulguei. Na hora que eu vi o cartaz de divulgação aí eu vi: Casa Laboratório-Ipatinga, e no outro dia Córrego dos Januários. Aí eu falei: nossa, tá brincando comigo! É muita coincidência! e o fato de, essa ligação que você teve com o pessoal do Rio, e eu tive os amigos lá, e isso fez a gente se encontrar.

Toquinha: eu nem te conhecia. Eu nunca tinha te visto, eu não me lembro. Os outros dois sim, o Evilásio e o Gustavo. Eu acho que foi uma coisa de Deus mesmo, eu acho. Assim, os encontros vão sendo tramados lá em cima.

Os amigos de Saulo eram também amigos dos componentes do Andança, e no trabalho de divulgação a rede começava a se formar, pois Saulo não sabia da história de que o Córrego dos Januários havia sido lugar de preparação para a peça a ser apresentada, e junto com o irmão Evilázio nos encontram no teatro, por acaso. Neste dia conversamos um pouco e é então que Saulo toma conhecimento do trabalho realizado na Casa de Memória e Cultura. Durante aquela breve conversa com nosso grupo, decidiu que iria ao Córrego para as outras apresentações do Andança, e depois dos espetáculos programados propôs fazer uma roda de choro, um momento musical. E assim fez, e a partir de então envolveu-se com o projeto, com ideias na área da música, possibilidades de 
entrarmos na rede da qual ele já fazia parte, e naquele fim de semana mesmo tornou-se o mais novo membro da nossa equipe responsabilizando-se por buscar incentivos para levarmos música para a nossa Casa.
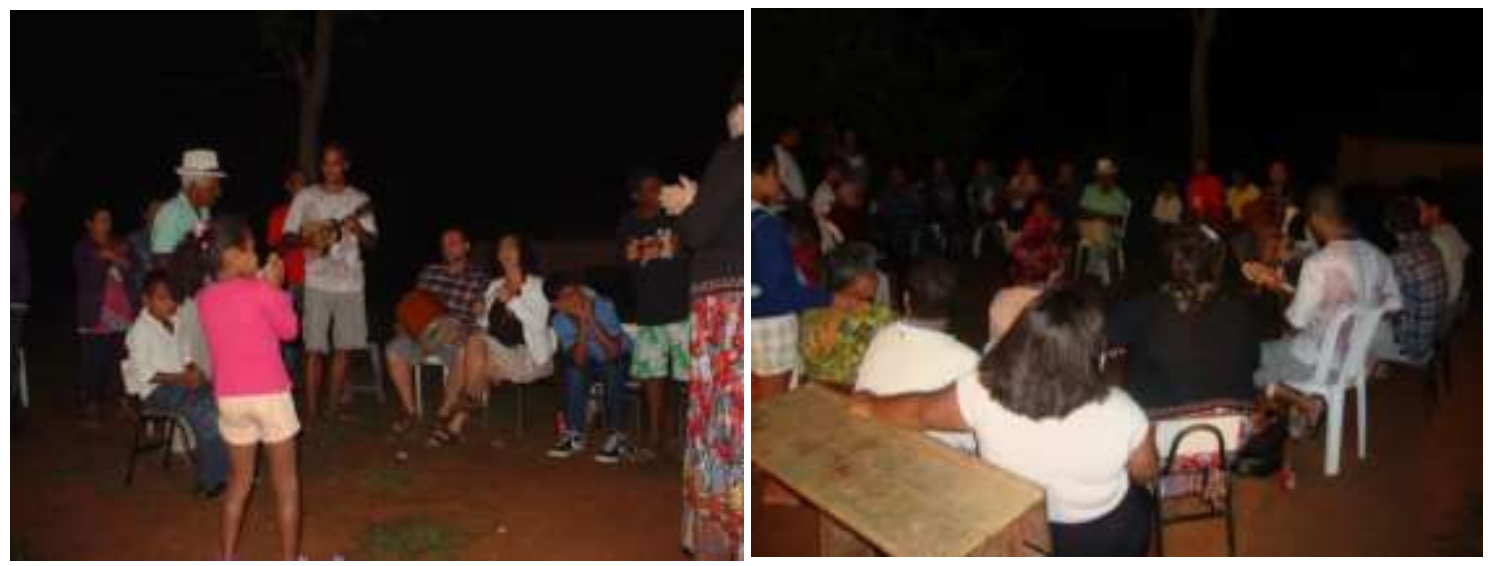

Figura 78: Roda de choro e de alegria 1

Figura 79: Roda de choro e de alegria 2

Entusiasmado com as possibilidades de trabalho na comunidade, Saulo programou um show com sua banda "Show do Vale", lá no nosso terreiro. No dia combinado, tivemos numa reunião com os integrantes da banda e a nossa equipe onde apresentamos nosso projeto, a nossa Casa. Para esta reunião Saulo também convidou Edvaldo da Costa, o conhecido Professor Alegria, um batalhador em prol da música e um defensor e divulgador da cultura negra nas periferias da região. Chegaram com muitos instrumentos de percussão e tinham orgnizado para antes do show uma oficina com toda a plateia. Não tínhamos estrutura para tanto, mas improvisamos, como sempre.
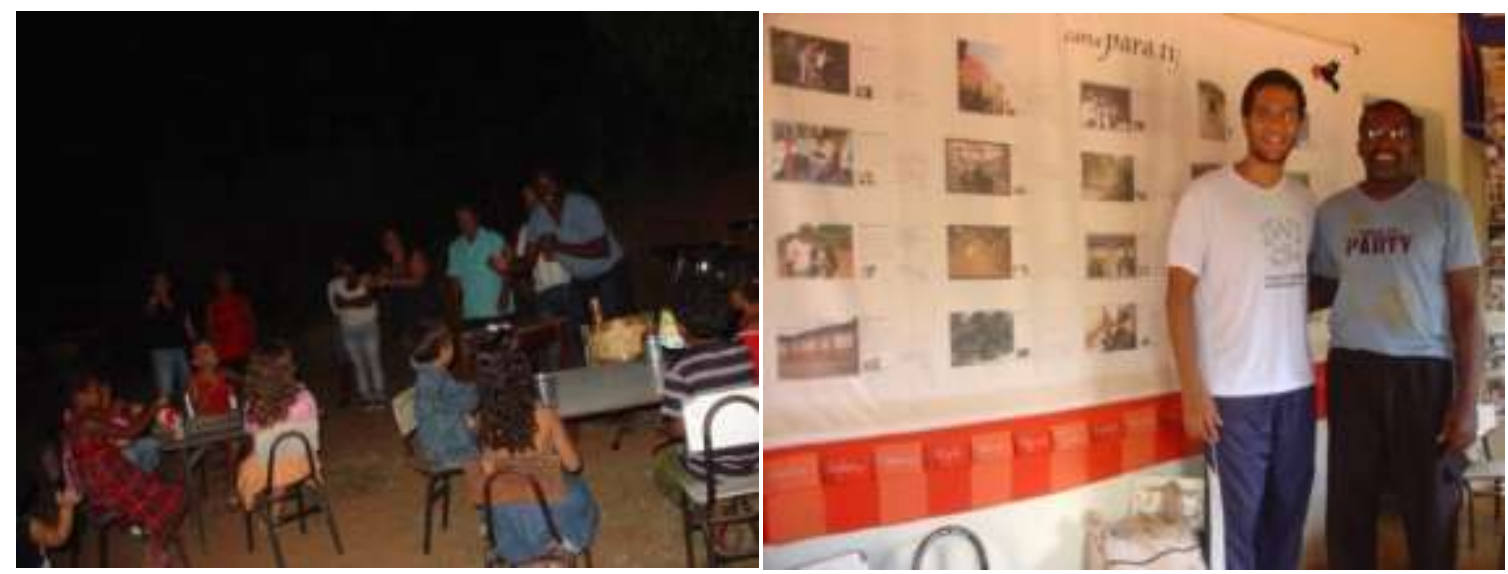

Figura 80: Oficina de percussão do Professor Alegria 1 Figura 81: Oficina de percussão do Professor Alegria 2 
A oficina aconteceu usando como instrumentos latas com sementes, cumbucas, canecas, tambores e caixas. Ao fim de quarenta minutos de trabalho do Professor Alegria, pudemos ouvir Ave Maria tocada pelos participantes da oficina, acompanhados do cavaquinho de Saulo Guedes. E depois a banda nos proporcionou uma noite de festa em que aproveitamos para vender comes e bebes para arrecadarmos recursos para manutenção da Casa.

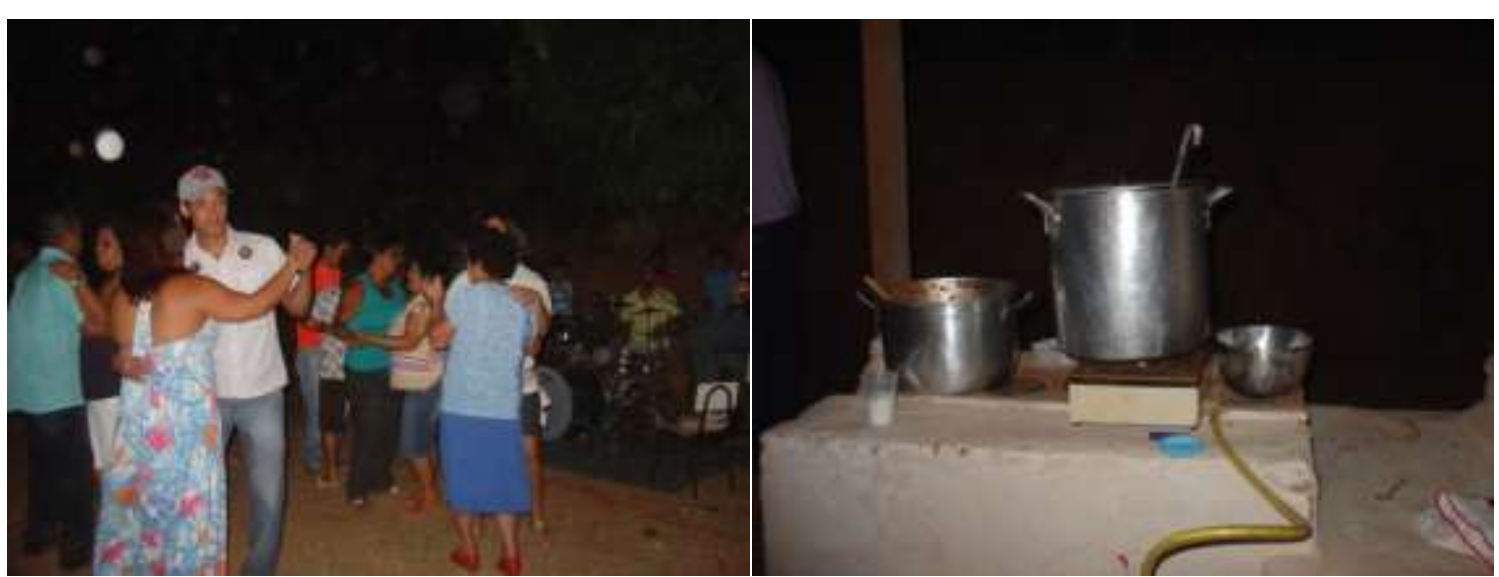

Figura 82: Olhando a banda a dançar 1

Figura 83: Comidas gostosas para arrecadar fundos

O Clubinho de Leitura, a Casa de Memória e Cultura, vêm sendo cada vez mais o lugar onde se semeia possibilidades. Quando recebemos visitas, quando realizamos atividades que saem da rotina, estamos na verdade realizando atividades que tempos atrás aconteciam nas casas de moradores onde se ouvia música e dançava. A igreja era espaço também para manifestações como o teatro, festas dos santos, e a escola fazia a festa junina. Não nos dávamos conta de que o lugar comunitário do encontro era tão necessário, tão importante como perpetuador de algumas atividades culturais tão nossas.

A geração de nossos pais e avós e os de minha geração, pelo menos durante a infância e adolescência, vivemos a experiência de ter algumas casas que cumpriam esse papel de lugar dos encontros, onde os jovens começavam a namorar, já que as moças eram sempre muito vigiadas, onde se ouvia música na vitrola, onde se fazia os bailes, com sanfoneiros do lugar, que só acabavam com o nascer do sol. Estes espaços foram rareando, os modos de vida dos últimos trinta anos foram nos levando, se por um lado para uma vida mais confortável, por outro, por mais isolamento. 
Numa de nossas reuniões de equipe conversávamos sobre isso, sobre o fato de hoje o espaço que era ocupado por essas famílias que gostavam de festas e abriam a casa para a comunidade não existirem mais, e nos demos conta de que de fato é necessário que as comunidades tenham esse lugar, e esse lugar hoje em dia para nós tem sido a Casa de Memória e Cultura. Pensávamos no papel educador que tiveram Seu Geraldino e D. Vita. Seu Izalpino e D. Mariinha, Sr. Cirilo e D. Sinhá, Tia Mariquinha e D. Bárbara, Seu Zé Inácio e D. Fiinha, pois eles cuidavam, estavam atentos. Eram casas em que tínhamos as portas sempre abertas, a alegria estava presente. Quando se queria fazer um baile alguém se incumbia de pedir autorização ao dono da casa, e uma vez autorizado era só chamar o sanfoneiro ou ligar a vitrola e pronto, a festa começava. O dono da casa impunha respeito, tudo transcorria bem. E ainda tinha um cafezinho no canto do fogão pra receber o povo.

A gente às vezes não se dá conta dos papéis sociais de pessoas que fazem coisas tão simples de forma espontânea. E nós vamos nos dando conta de nosso lugar comunitário. São muitos papeis a serem desempenhados numa comunidade, e o nosso tem sido este, o de receber o povo, oferecer momentos de vivência com as artes, com a alegria. Muitas vezes nos sentimos desestimulados, questionamos nossa atuação, mas durante essas conversas conseguimos perceber o caminho percorrido e recuperamos energias. E o balanço das nossas atividades, que fazemos regularmente, vem nos mostrando a construção de uma realidade, de superação, de consciência e transformação que vem se dando no tempo possível, mas que tem uma energia do cuidar que permanece, que é sempre lembrada.

Jupira: Igual a gente vê, hoje há muita reclamação a respeito da disciplina dos meninos na escola, então essa escola é um agente de transformação do indivíduo, do jovem, do adolescente. Eu acho isso aqui um trabalho muito bom, muito bom mesmo, agora, temos as dificuldades, que são grandes, muita dificuldade. Mas assim, tudo que é bom tem dificuldade, as coisas fáceis elas não têm tanto valor não, sabe. Mas se nós pudéssemos fazer disso aqui um encontro de pessoas, realmente o que a gente fizer aqui, nosso Deus! a gente passaria a ser destaque. Hoje tem muita coisa na sociedade, então as coisas boas, elas fazem diferença. Hoje o que faz a diferença é a coisa boa, porque tem tanta coisa ruim aí. O que marca, o que faz elevar as pessoas é isso aí, cultura, a gente tem que saber das coisas, a gente tem que saber. O convívio com as pessoas, né, isso é fundamental. Essa casa ela tem condições pra isso, não sei, nós estamos muito devagar, eu acho. Vocês concordam comigo ou não?

Toquinha: eu acho que a gente tá devagar, mas é porque as pessoas que estão disponíveis pra trabalhar na casa, nós somos poucos. Se tivesse mais gente durante 
a semana, né Edervanio, pra fazer outra coisa uma vez na semana, que tivesse outras pessoas que pudessem dividir com a gente pra revezar mais, porque a gente vir todo sábado...

Jupira: ah, é difícil.

Dayane: eu não penso assim não, apesar das dificuldades também, a gente acaba, o que a gente faz por essas crianças assim eles tem o exemplo da gente tentando fazer, mudar algumas coisas, tentando fazer algo diferente. Eu acho que estimula eles também a, igual a gente já vê hoje o Sávio, ele tá sempre ajudando alguma coisa.Os meninos estiveram aqui (oficina do grupo "Filhos da Terra" com Rômulo e Cleonice) ele tirou foto dos meninos e tal. Por mais que às vezes são coisas simples, mas eu acho que são coisas que fazem a diferença. Eu acho, as crianças, eu acho que veem um espelho na gente.

Edervanio: a gente tá aqui hoje, a nossa participação no projeto hoje é resultado de algo que foi acontecendo, assim, naturalmente. A gente começou participando, vinha ler um livro, sempre chamavam pra ajudar, pra gente tá junto e foi acontecendo. E foi através dessas coisas simples, só de tá ali, ajudar a carregar uma caixa de livros, ajudar a olhar uma criança, quem sabia ler um pouquinho mais ajudar o outro ler, então, através desses atos simples que as coisas foram acontecendo, e a gente tá aqui hoje.

Toquinha: você, Edervanio, tá desde o começo, que você chegou a me pedir pra ajudar. Cê era bem novo ainda, o que cê sente assim, que você que vem mais à comunidade, você percebe alguma mudança na comunidade por conta da casa, alguma atitude que acha que não tinha antes e que hoje tem, que você...

Edervanio: pra mim, a Casa representa um avanço pra comunidade. Mesmo que às vezes temos essa dificuldade das pessoas perceberem a casa como esse avanço eu tenho essa concepção de que isso representa um avanço. Porque aqui, eu sempre associo essa casa à nossa identidade, né, a história do povo do Januário, a história da comunidade tá toda representada aqui. E eu penso assim, que ao longo do tempo as pessoas mesmo que às vezes distante, mesmo que à maneira delas elas foram participando desse processo, processo de resgatar essa identidade. Então eu penso assim, mesmo que elas ainda não percebam totalmente essa casa, mas ela representa sim esse avanço, devido a esse fato, de aqui tá contida a nossa identidade.

Dayane: eu acho que essa questão, igual a Jupira falou, de encontros, né, assim, por causa das vezes que a gente se apresentou nas escolas e tudo, a questão assim da união entre as pessoas. Igual essas serestas que a gente faz, são coisas que às vezes, talvez no final a gente vê assim que não tá sendo tão lucrativa, mas eu acho que a gente também tem que olhar além da parte do lucro, do financeiro; eu acho que o maior objetivo da gente é buscar essa aproximação, essa união entre as pessoas, voltar a ter essa aproximação mesmo como era antes, né, eu acho que é o mais importante, o objetivo principal, eu acho.

Toquinha: o diferencial que eu acho aqui nessa casa é que a forma que a Denise trabalhou, a comunidade se tornou dona da Casa, eu percebi isso. É diferente de outras casas de memória que alguém constrói uma coisa e entrega. Essa casa é nossa, da gente, a Denise passou a ser também da comunidade. Eu acho que o diferencial aí é, que eu percebo, eu que tô indo mais pra longe, e quando eu falo do trabalho, o que eles me falam é isso: começou de um sonho meu, né, que se tornou um sonho comunitário. Eu acho que isso é que encanta as pessoas. As pessoas, todos os lugres que eu apresento, que a Denise apresenta, as pessoas choram, se emocionam, por conta desse ainda espírito de comunidade. Aí como que vocês vêm, vocês que ficam aqui?

Edervanio: tem também, como a Jupira falou, a questão da transformação, né, quando cê fala que era um sonho seu, mas que passou a ser um sonho compartilhado, um sonho da comunidade. São os processos de transformação que 
vão acontecendo, né. Um vai transmitindo pro outro e daqui a pouco torna-se algo coletivo. È isso, só complementando, é a questão da transformação que você falou.

Essa transformação expressa por Edervanio, hoje psicólogo, vem acontecendo, mas no correr da vida muitas vezes não a percebemos. Os altos e baixos pelos quais passamos, quando desanimamos e achamos que não podemos mais, não pensamos na alternativa de encerrar os trabalhos, pois a Casa nos pertence com todos os problemas, com todas as alegrias, com todo o trabalho que não damos conta de realizar e que vez por outra aparece um amigo, um visitante novo a recarregar nossas baterias e nos preparar para outra etapa. Vem sendo assim.

$\mathrm{Na}$ nossa relação com a escola vivenciamos situações até certo ponto engraçadas, pois, como lá no início dos trabalhos em 2001, nós fazemos questão de visitar a escola e de que a escola nos visite. E eu, sempre que estou na comunidade, gosto de ir lá conversar com as professoras; nem sempre tem a ver com o trabalho, é uma visita mesmo, à mineira. Mas toda vez que chego as professoras já perguntam se eu preciso de alguma coisa e as crianças ficam ansiosas por saber se eu vou contar uma história, levar algum visitante ou convidar para algum evento. Eu sempre tenho que conversar um pouquinho com os alunos. Em junho de 2013 eu fiz a oficina de leitura no Clubinho, no sábado, e contei/li a história "O macaco e a velha", uma versão do livro "Histórias que o povo conta", de Ricardo Azevedo. Durante a leitura eu improvisei uma musiquinha para os versos, que as crianças aprenderam rapidinho. Quando acabou eles pediram para contar mais, e combinamos outro dia de histórias. Quando saímos do Clubinho e íamos juntos pela estrada eles já iam improvisando outras letras para a música que tínhamos inventado para as trovinhas da história. E num dado momento eu disse a eles que eu iria na escola na hora do recreio para merendar com eles, e eles logo me pediram: você conta a história lá na escola de novo? Eu expliquei a eles que precisava combinar com as professoras, que eu não podia chegar e ir contando história porque as professoras tinham um planejamento a cumprir. Mas aconteceu que eu não pude ir à escola e acabei voltando para o Rio. Um mês depois eu voltei lá e a primeira coisa que fizeram foi pedir para eu contar a história do Macaco e a velha de novo e para ir à escola contar para os 
colegas que não podiam ir ao Clubinho. Prometi falar com as professoras e combinar uma contação de histórias.

Numa segunda-feira fui à escola falar com as professoras e levei o livro na bolsa pra mostrar a elas e combinarmos uma leitura, e quando cheguei no portão da escola João Laender e Maria Eduarda, sairam na porta e me fez sinal de positivo, e depois eles e os colegas me falaram que já haviam falado com a professora que eu iria lá para contar a história, e ela já havia autorizado. E eu soube então que eles chegaram naquele dia comentando sobre a leitura. João Laender, Jamile, Maria Eduarda, Sandro e Carlos Eduardo organizaram tudo com a professora e na hora do recreio eu li para eles "O macaco e a velha". Durante a leitura, no momento da musiquinha, eu deixei a cantoria por conta deles. Foi uma festa! Quando terminei de ler começou a disputa para ver o livro.

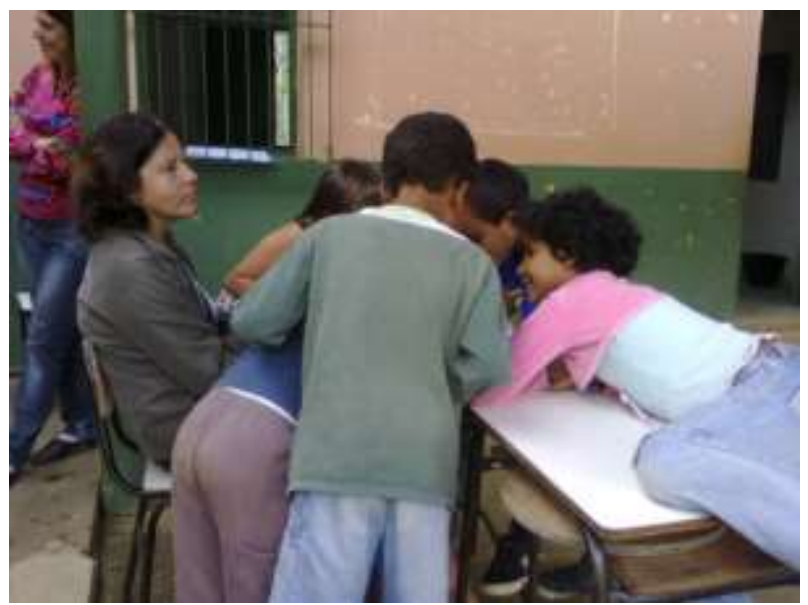

Figura 84: Professora Lúcia e os alunos com o livro de mão em mão

Depois era bonito ver os meninos lendo para os colegas e alguns esperando a vez de ler sozinhos.
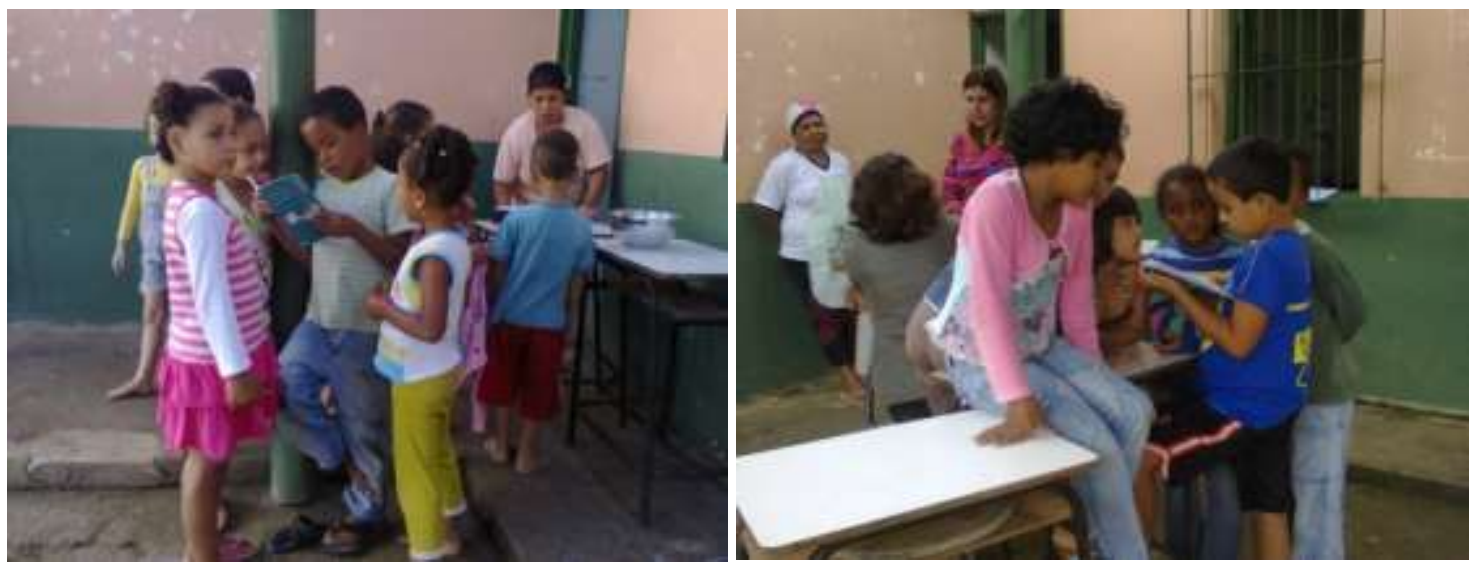

Figura 85: João Laender lendo para os colegas Figura 86 Leonardo lendo para os colegas 
E na conversa com a professora Eliane ela me conta da empolgação dos meninos com a nossa leitura da história.

Eliane: isso. Pois é, aí chegou ela mesmo comentando da história, de tão empolgada que ela ficou. Eles gostam de ouvir história, né?! Aí, o que que acontece, eu acho que quem vai mais lá é ela, igual eu tava te falando, se fosse o caso de ter uma oportunidade dos outros alunos do primeiro ano poder frequentar também pra ter a mesma empolgação dela, ia ser bom demais. Porque chegava na segunda-feira poderia ter um momento com eles de, igual quando eles voltam eles não querem contar o que fizeram no fim de semana, aquela coisa toda?! aí, com aquela empolgação, eles iam contar a história que eles leram, que eles ouviram, sabe, cada um contava a sua história. Ainda mais agora que eles estão no processo de alfabetização, ela (a Jamile) consegue ler até alguma dificuldade, coisa assim que a gente nem ensinou, mas ela é inteligente, ela já consegue ler. Ela pode pegar um livrinho pequenininho que ela dá conta de ler.

Eliane se encanta com o aprendizado de seus alunos, e vê no Clubinho um incentivador do aprendizado da leitura, do gosto pelo livro, mas sente que nem todos os seus alunos possam frequentar. Por estarmos situados numa localidade rural e, como a Prefeitura ultimamente tem agrupado crianças de várias comunidades numa mesma escola devido ao número reduzido de alunos por comunidade; e a facilidade de, com o transporte escolar, os alunos serem levados de comunidades vizinhas para a escola da nossa comunidade, inviabiliza a visita regular de todos alunos dessas outras comunidades ao Clubinho para as atividades aos sábados. E não temos pessoal para atender os interessados durante a semana. Vamos trabalhando da forma que é possível, temos consciência de nossas deficiências e pouco a pouco vamos nos dando conta do quanto poderíamos contribuir nesse processo de aprendizado, de formação da nossa cultura.

Eram comuns, no século XIX, os serões na hora do jantar, assim como no refeitório de mosteiros e de internatos, em que um público, letrado ou não, ouvia leituras pontuais, sem ter o livro nas mãos. No caso da narração para crianças, o livro aberto no colo do leitor, apresentado em suas imagens, tem outras e interessantes funções. O contato com a narrativa em seu suporte material, com as imagens, a textura do papel, do pano ou do plástico (o que exige que o livro passe de mão em mão), bem como seu cheiro, seu formato, colaboram para uma familiaridade com o objeto e preparam uma fase da relação com a escrita, que não elimina nem substitui a primeira fase da interação com a narrativa oral ou oralizada.

Ouvir é o primeiro passo e está necessariamente ligado com o falar: escuto, imagino coisas, sou provocado, penso e sinto vontade de falar. A palavra que vem de fora perpassa o ouvinte, ganha cores próprias segundo a interação que se estabelece e é soprada de volta como réplica ou comentário que não se pode calar. O diálogo que se treina, nessas situações, vai agilizando o pensamento, desenhando-se como modalidade de comunicação, em que o receptor se torna 
emissor, trocando continuamente de posição, de forma ordenada e atenta: isso estimula o convívio e a cooperação, a alternância e o respeito no aprendizado "imperceptível" da vida e do mundo. (YUNES, 2009. p. 18-19)

O Clubinho de leitura vem nos ensinando que as surpresas de uma história podem desencadear enredos, proporcionar momentos de leitura-brincadeira, de invenção, de imaginar mundos outros, e que a escola pode ser um espaço comunitário permitindo a intervenção de vizinhos que tenham o que levar para o espaço oficial de ensino. Estas experiências vêm se dando desde o início. E nossas intervenções na escola são sempre com a ideia de que a comunidade em torno de uma escola faz parte da escola, é o meio social por onde circulam os alunos e por isso devem contribuir para levar a comunidade para dentro da escola e a escola ser de fato parte da comunidade.

Numa outra tarde às voltas com o livro "Língua de trapo", de Adriana Lisboa, as crianças criaram sua própria boneca, se divertiram com materiais trazidos de casa e restos encontrados nas nossas estantes.
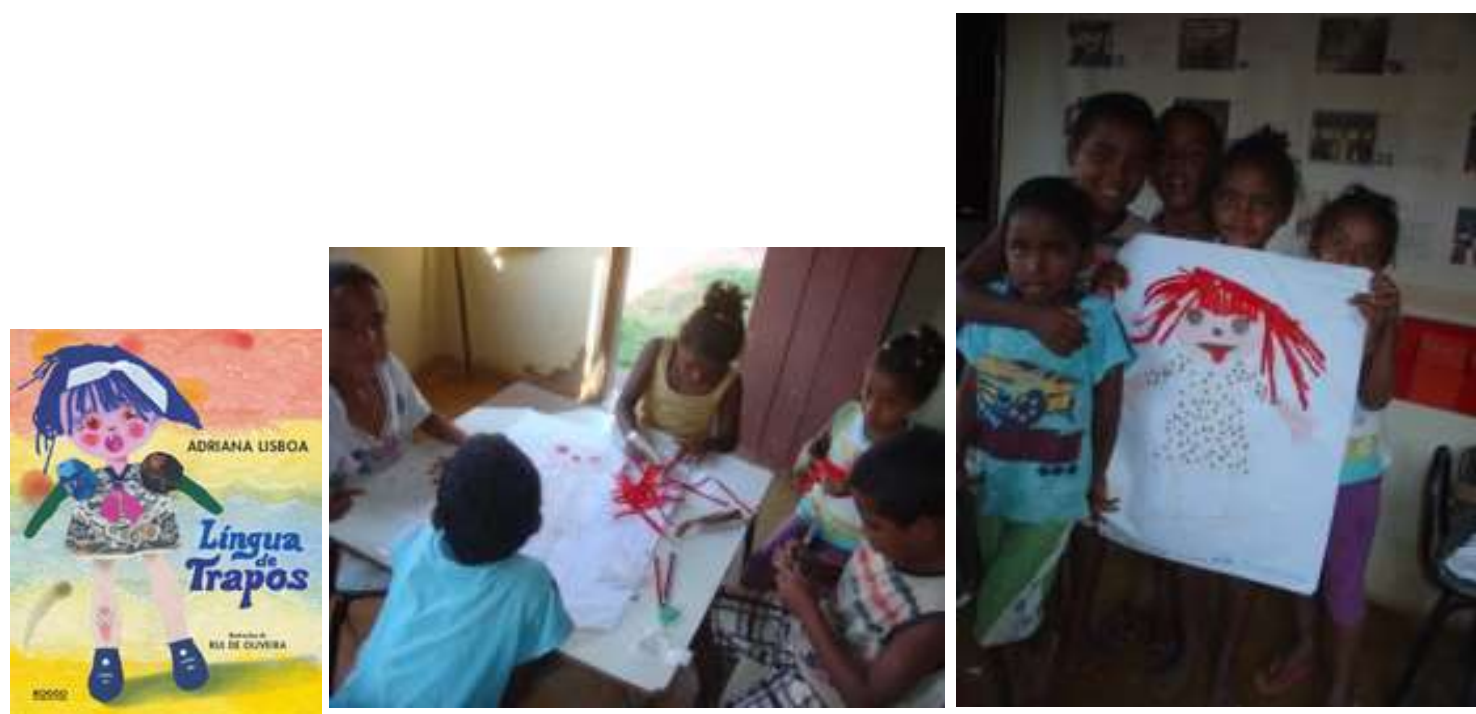

Figura 87: Livro "Língua de trapos", de Adriana Lisboa Figura 88: Língua de trapos, papel e brincadeira Figura 89: Crianças e obra de arte coletiva

A professora Lúcia, que acompanha nosso trabalho desde o começo, fala sobre da contribuição do Clubinho de Leitura e da sua relação com a escola.

Lúcia: olha, contribuiu muito, muito mesmo, porque através do Clubinho de Leitura eles tem mais contato com o livro, mais contato com a leitura. Eu observo, já observei desde que a gente começou com esse trabalho aqui, que eles, principalmente os que moram aqui, que frequentam mais, eles desenvolveram mais 
gosto pela leitura. Sempre que a gente trabalha uma atividade literária, principalmente literatura, eles relacionam às vezes alguma história, sempre que tá lendo, eles sempre comentam de algum livro que foi lido lá. Comentam muito. Principalmente os meninos daqui. Vou falar assim, tem um livro lá no Clubinho de Leitura que fala sobre isso, então eles sempre lembram, principalmente os meninos que moram aqui mais próximo e que frequentam mais lá. Eu falo o Sandro, por exemplo, esses que frequentam mais, eles sempre lembram. E, a leitura é a base de tudo, e criança, pra ler, é incentivo, né. O Clubinho de Leitura é um incentivo à leitura. Com isso eles panham gosto, né. Eu sei que melhorou, ajuda e ajuda muito.

E conversando sobre a relação da comunidade com a Casa de Memória, Lúcia reconhece o envolvimento da comunidade e dá ideias para melhor aproveitamento do material disponível no Clubinho e na Casa como um todo.

Toquinha: O pessoal gosta quando tem coisa (eventos) lá na casa.

Lúcia: mas gosta mesmo. Todo mundo valoriza. A comunidade valoriza muito aquilo ali, eu acho interessante. Sempre que tem alguma coisa eles fazem questão de tá ajudando, de tá apoiando. Infelizmente, é isso que você falou, falta mais voluntários, teria mais momentos, né. A gente até tem, já tá desenvolvendo um bom trabalho, mas eu acho, de repente, aqui a comunidade já é envolvida, né, a comunidade já é envolvida. Eu acho que, outro dia eu até pensei isso, aqui na escola mesmo, nas reuniões da escola, podia estar pondo para os pais essa questão do Clubinho de Leitura, de repente não abrindo só pra comunidade, já tem esse convite, mas de repente promover um momento que os pais em geral fossem lá visitar, ver a disposição dos livros, e os meninos, mesmo que o pai mora longe tivesse condições de tá encaminhando os meninos no dia que tem voluntários lá. Que a comunidade não é tão longe assim. Aqui as crianças que vão ali, que frequentam, as mais próximas frequentam, os que moram mais distante não tem como. De repente se levasse para os pais a importância desse Clubinho, desse contato com o livro e eles tivessem assim, não sei, de repente, até mobilizando. Um desce, se for todo fim de semana, um desce, traz, o outro pai desce, traz, se tivesse fazendo isso essas outras crianças iam ter contato também. E o mais é tá convidando mais gente pra ser voluntário também. Precisa mais gente.

A escassez de equipamentos culturais dificultam o acesso ao livro e a outras expressões da nossa cultura. Quando a professora reivindica, solicita mais divulgação das atividades que oferecemos esbarramos numa realidade que nos impede os avanços, pois sem recursos, sejam oriundos dos órgãos públicos ou da iniciativa privada, ficam ainda mais limitadas nossas possibilidades de atingir comunidades vizinhas. A escola tem sido nosso meio de contato com essas comunidades, mas o ideal seria que cada comunidade tivesse seu lugar de lidar mais sistematicamente com a sua cultura e através disso acessar o que acontece fora de seus limites. E então eu pergunto pela forma como o Departamento de Educação, responsável pela nossa escola, vem tratando a questão específica da leitura na sala de aula. 
Lúcia: nós temos, assim, nós desenvolvemos o projeto "gente que lê". Esse projeto iniciou ano passado e a gente tá continuando com ele, eu pelo menos tô continuando. Toda semana, a leitura mesmo, já tem os dias de leitura próprio, na nossa grade, mas de quinze em quinze dias por exemplo, os meninos leem o livro e depois faz a apresentação do livro pros colegas. Eles todos fazem trabalhinhos de literatura e depois preenche a ficha literária do livro. Aí vê editora, autores, ilustradores, a história do livro... esse trabalho a gente desenvolve. Pelo menos com a minha turma eu desenvolvo, e ela (a outra professora) também tem os dias de aula de literatura dela, e fazem. Aí esse é o trabalho que a gente tá fazendo de leitura. E o mais é leitura mesmo, por exemplo, tirar alguns momentos específicos pra leitura. Dentro da semana nós temos dois dias, os meninos na escola geralmente já lê o tempo todo mesmo e tal, mas é diferente.

Toquinha: é diferente.

Lúcia: o momento da leitura, precisa dele. Aí nesse momento a gente tem caixa de texto, igual na minha sala aqui eu tenho, tem texto de historinhas, um mucado de poemas, um mucado de piadas, tem de panfletos, um contato com, até das revistas dos livros que eles adoram e que, né, leem muito.

Toquinha: toda sala tem seu cantinho de leitura? E esses livros são renovados? Como que é?

Lúcia: toda sala tem seu cantinho de leitura. E os livros têm sido renovados. Sempre eles (o Departamento de Educação) tá trazendo, e a gente tá com bastante, com novos livros. E o que nós fazemos, por exemplo, esses que estão na minha sala aqui eu sempre troco, a gente tem caixas com livros lá dentro, às vezes eu separo. Os meninos já leram, já estão ficando de lado os livros, aí coloca lá e traz outros, sabe. Igual, a minha turma aqui, eles leem muito. Esses livros que eu tenho aqui já tá na hora de pegar, por exemplo, o cantinho de leitura da Eliane, que é segundo e terceiro ano, só que eu não olho se é segundo ou terceiro não, o que importa é o livro, o gosto, é leitura mesmo. Então, eu costumo pegar, outro dia eu peguei os livros dela e trouxe pra cá. Os alunos dela entram aqui e pegam livro também e levam pra lá e lê. Então, estão gostando. Porque que eles leem. Eu tenho alunos aqui que já leram todos os livros. A maioria, já leu todos os que estão aqui e todos os que estão lá na sala da Eliana. Aí o que que a gente faz? A Adélia traz do cantinho de leitura, do Clubinho.

Lúcia conta da iniciativa de Adélia, uma das pessoas da nossa equipe, que sentindo a impossibilidade de todas as crianças frequentarem o Clubinho, leva o

Clubinho até a escola.

Lúcia: já trouxe. Ano passado nós fizemos, então já tá na hora de fazer de novo. Porque quando começa a esgotar a Adélia traz, aí às vezes empresta, eu tô até com um ali pra devolver lá, que tá com a minha menina, ela já leu e eu tenho que devolver. Mas aí o que que a gente faz: o ano passado a Adélia, a última vez que ela trouxe foi no fim do ano, eles já tinham lido, você vê que já leram, já não tá mais aquele encanto... Aí a Adélia trouxe, contou os livros, umas revistas em quadrinhos. Aí leram, entregou, devolveu. Já tá na hora de começar a fazer de novo, porque lá tem muitos livros que os daqui não conhecem, as crianças que não frequentam o Clubinho de Leitura. Então tá na hora de tá trazendo de novo, ou de tá indo lá. Sempre quando chega coisa nova, livro novo, os meus (alunos) mesmo, nossa mãe! eles ficam entusiasmados demais. A maioria deles gostam mesmo, procuram muito. Aí quer levar pra casa, aqui da escola, manda pra casa, volta de novo o livro. 
E a professora nos solicita mais participação junto aos alunos, mais interação.

Lúcia: o que eu tenho é que elogiar. Eu acho que é superinteressante, foi bom pra nós, bom pros professores. Eu peguei mais, né, a Marceni pegou bastante também, eu acho que foi excelente. Só aprendi. E bom pros meninos também.

Toquinha: tem uma galerinha já adolescente que acompanhou mais, a gente trabalhou mais.

Lúcia: Mas eu até acho que poderia ter mais. Podia até voltar aquele projeto igual nós começamos, do livro, da história (história da comunidade). Naquela época foi da Denise. Mas podia tá voltando. Fazer de novo com essa turma nova agora. Bom, eu acho que é superinteressante. É muito bom! E tem que explorar muito aquilo ali. É uma riqueza que a comunidade tem, essa Casa de Cultura.

Nossa intercessão com a escola vem sendo no sentido de que a Casa de Memória, o Clubinho de Leitura, sejam uma extensão do espaço escolar, um lugar que os alunos possam explorar. Lugar de novas experiências. O contato direto com o livro, a liberdade que cada um tem de fazer dela a sua casa e ser membro de um Clubinho sem muitas regras, além de usufruir do prazer de ter um livro nas mãos e explorá-lo. Desde que foi criado nunca tivemos uma meta a ser alcançada, fomos avançando dia a dia. A minha função, por ter idealizado e desejar muito este espaço, e de depois ter chegado à faculdade de Letras para me instrumentalizar e atualizar meus conhecimentos em se tratando de criar e gerir salas de leitura, de me dedicar mais ao aprendizado da lida com a literatura infantil e juvenil, tem sido a de coordenar os trabalhos, de reunir as ideias em equipe para tentarmos juntos traçar metas, planejar atividades mais a longo prazo, mas sempre somos cerceados pela contingência. Então vamos avançando da forma que é possível, driblando os impedimentos, e temos nos surpreendido com os resultados.

Nesse meu lidar mais de perto com o mundo da leitura para crianças e adolescentes, me encontro com a professora Sonia Kramer e suas ideias, dentre elas o tema da "leitura como experiência".

Levar algo da literatura para além do seu tempo, para além do momento mesmo em que se realiza: aqui reside a dimensão da experiência. Trata-se de uma leitura que produz uma "reflexão sentida" de um coração informado sobre aspectos essenciais da vida humana; leitura compartilhada - ainda que seja com autor - daquilo que a gente pensa, sente ou vive. Leitura que provoca a ação de pensar e sentir criticamente as coisas da vida e da morte, os afetos e suas dificuldades, os medos, os sabores e dissabores; que permite conhecer questões relativas ao mundo social e às tantas e tão diversas lutas por justiça (ou o combate à injustiça). Compreender a leitura desse modo, a partir desse olhar teórico, exigem que se reconheçam valores 
menosprezados pela sociedade contemporânea: valores tais como generosidade, solidariedade e coletividade - enquanto se enfatiza o culto do indivíduo, de suas necessidades e de sua esperteza em passar a perna no outro, e levar vantagem, obter ganhos pessoais e ganhos de poder.

Quando penso na leitura como experiência (na escola, na sala de aula ou fora delas), refiro-me a momentos em que fazemos comentários sobre livros ou revistas que lemos, troçando, negando, elogiando ou criticando, contando mesmo. Situações em que- tal como uma viagem, uma aventura - fale-me de livros e de histórias, contos, poemas ou personagens, compartilhando sentimentos e reflexões, plantando no ouvinte a coisa narrada, criando um solo comum de interlocutores, uma comunidade, uma coletividade. O que faz a leitura uma experiência é entrar nessa corrente onde a leitura é compartilhada e onde tanto quem lê, quanto quem propiciou a leitura ao escrever, aprendem, crescem, são desafiados.

Defendo a leitura da literatura e dos textos que têm dimensão artística, não por erudição, mas porque são textos capazes de inquietar. (KRAMER, 2003. p. 29-30)

Kramer alerta para a necessidade de compartilhar a leitura, para o fato de que pensarmos juntos sobre um texto, uma história, pode nos ajudar na compreensão, na recepção mais aprofundada de suas muitas mensagens. Essa leitura que vira conversa, que não busca por respostas certas de questionários ou fichas literárias, que permite o riso, o "não gostar", mas que é uma atividade de pensar, de provocar é a que eu venho acreditando antes mesmo de ter conhecimento deste conceito. As minhas próprias leituras, as que me comovem, são as que eu possa mastigar, passar pelo meu entendimento e torná-las minhas. E mesmo na vida acadêmica, quando leio um texto difícil e depois de muito lidar com ele eu o apreendo, capto sua mensagem, entendo o que ele quer me dizer, é uma conquista, uma amizade construída. Quando eu leio a história do "Macaco e a velha" e as crianças morrem de rir por conta das trapalhadas da pobre velha que se julga muito esperta, cantam e inventam novas letras, a leitura ganha outros contornos, outros sentidos e todos saímos ganhando. Quando um texto de filosofia, por exemplo, em que preciso me debruçar sobre ele horas, dias, anos, ou quando leio/ouço uma história lá no Clubinho de Leitura, com os meninos de lá, são fruições distintas, mas é essa possibilidade de uma experiência, de inserção nas entranhas do texto. A leitura literária vem me permitindo, literalmente, a criação, a descoberta de novos mundos. Quando depois da leitura de uma história as crianças criam suas próprias letras para a música inventada ali, de improviso, tendo como ideia as cantigas de roda de quando eu era menina, essa história ganhou o coração delas. A risada por conta do uso de palavras não muito "recomendadas", a necessidade que sentem de que também os colegas 
ouçam/leiam, querem dizer, na minha interpretação, que degustaram a história, que já a tomaram para si. E isso o conto popular tem facilidade em conseguir. Peripécias, confusões, trapalhadas são a glória para as crianças.
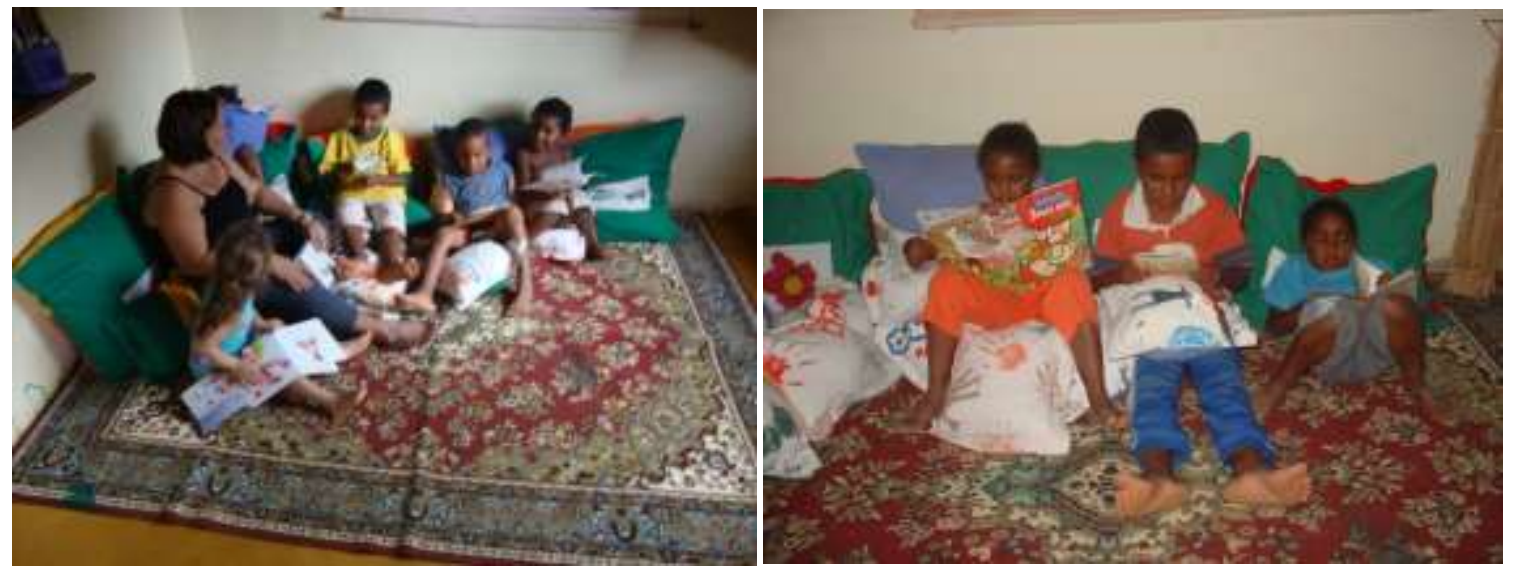

Figura 90: Dia de Clubinho 1 (Foto de Sávio)

Figura 91: Dia de Clubinho 2

Nossas experimentações já duram onze anos. E durante esse tempo temos recebido o reconhecimento do que estamos fazendo. Por quatro semestres seguidos Nossa equipe tem sido convidada, a contar a nossa experiência aos alunos da disciplina Psicologia e Realidade Rural, do oitavo período de Psicologia do Centro Universitário de Caratinga - UNEC, em Caratinga-MG, a convite do professor Walber Gonçalves de Souza. Nessas ocasiões Edervanio, junto com os demais membros da equipe ou mesmo pessoas da comunidade que não fazem parte da equipe de trabalho que possam acompanhá-lo, conta a história de concepção da Casa de Memória e Cultura e os trabalhos realizados. A fala de Edervanio, com a apresentação das imagens que são o registro das nossas ações, permitem um debate em que a tônica da discussão entre os alunos é sempre sobre a emoção, a beleza das imagens e de que se reconhecem nelas, pois na região são muitas as comunidades rurais semelhantes à nossa. E sempre ressaltam o fato de que coisas simples, a história da própria comunidade, mobilize para mudanças tão significativas. 


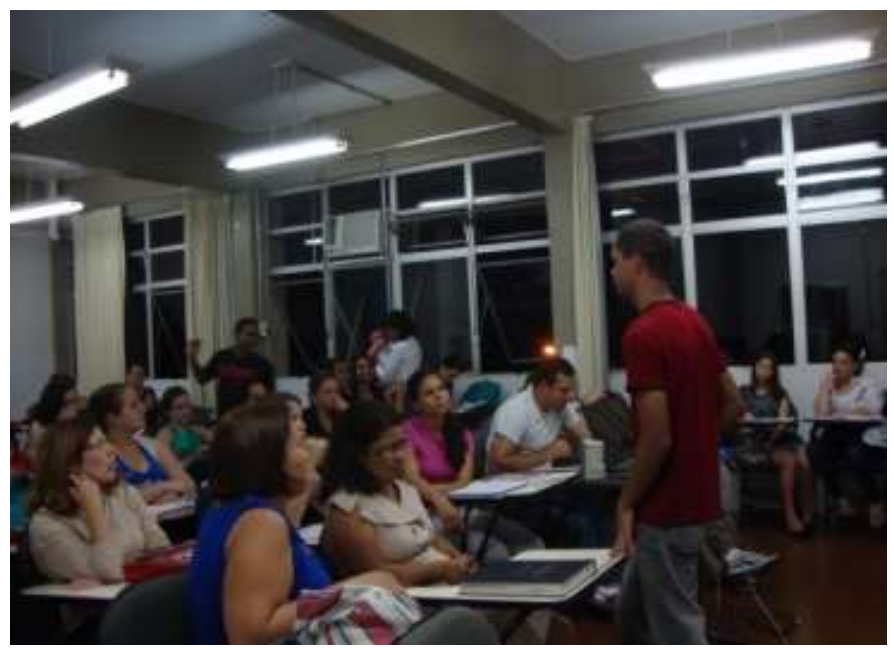

Figura 92: Casa de Memória e Cultura na UNEC-Caratinga/MG

O Clubinho de Leitura é um lugar de fazeres, na grande maioria das vezes, experimentações. A minha contribuição nessa estrada de muitos desejos, uns realizados e muitos por realizar, na companhia de muita gente que acredita que juntos somos mais capazes, é minha forma de retribuir o que me foi dado pela vida, o acesso a uma biblioteca. A liberdade que me foi dada de provar da literatura, pela leitura e pela escrita, me ajudou a ser quem sou hoje. Quem somos.

\begin{abstract}
Surge no final do percurso o hospede inesperado (...) o reconhecimento como gratidão: "Ter reconhecimento por, demonstrar reconhecimento". Percebe-se a conexão com o que precede; a admissão da dívida com relação a alguém, admissão dirigida a esse alguém, coloca no caminho da gratidão sob a condição da adição da ideia de um movimento de retorno, espontâneo, gracioso, em todos os sentidos da palavra, como se uma dívida fosse restituída. (RICOEUR. 2006, p.19)
\end{abstract}

Ao escrever dívida, Ricoeur me leva a entender como necessidade, pois desde muito tempo, talvez desde a infância, eu acho que quando uma coisa muito boa acontece é preciso ter alguém para contar. Mas esse contar não é pensado como doação, em dar não no sentido filantrópico, mas no sentido de que preciso de alguém que partilhe comigo daquele aprendizado, daquela beleza, daquela alegria. É necessidade de companhia na aventura da descoberta. É porque sozinha apreendo pouco da experiência, e juntos podemos doar cada um a sua experiência e acrescentarmos significados, ampliarmos horizontes. E nesse ampliar horizontes, Denise tem sido essa parceira que confia, que me anima, no sentido mais viceral da palavra. E ela escreve lindamente uma carta falando sobre esse nosso encontro marcado. 


\section{Do Córrego ao Rio, do Rio ao Córrego}

Na tese II sobre o conceito de história, Walter Benjamin ${ }^{12}$ nos fala de um encontro marcado entre as gerações precedentes e a nossa para qual o passado dirige um apelo.

Sempre penso nisso quando relembro a jornada que vivi com Maria de Lourdes Souza, a Toquinha, e os moradores do Córrego dos Januários. E por isso me emociono com o início do título de sua dissertação: do Córrego ao Rio... Pois foi aí, quando Toquinha sai do Córrego dos Januários e vem para o Rio de Janeiro que nosso encontro começa a se engendrar.

O primeiro contato seria feito pelas mãos de Luana e serei sempre grata a ela por isso. Escrevia uma monografia para o curso de Especialização em Educação Infantil da PUC-Rio sobre a qualificação de babás e berçaristas e refletia sobre a construção do leitor/escritor nos cursos de formação de profissional de creche quando Luana me chamou para o lançamento de um livro de contos que Toquinha participava.

Lembro bem do impacto que a leitura de "Amor de viajante" me provocou. Entendi que não estava diante de uma babá que escrevia mas sim de uma belíssima escritora que pelas circunstâncias da vida era babá e empregada doméstica. Considero este dia um marco nas nossas vidas. Foi este encontro que me levou do Rio ao Córrego pois decidi seguir o curso das palavras que Toquinha escolheu para contar suas histórias.

Encontro vivido com surpresas. Afinal, como imaginar que naquele lugarejo circularia a dor e a queixa pela falta de convivência? Mas uma cidadezinha é uma cidadezinha, e é preciso compará-la a si mesma, e não a um grupo de outra natureza nos lembra, Maurice Halbwachs. ${ }^{13}$ Toquinha constata mudanças que certamente não seriam percebidas por um forasteiro que rapidamente se encantaria com o acolhimento e a estética simples e poética do Córrego. A escritora, que comemorou a chegada da luz, adverte: "A memória do meu lugar está se perdendo." E é com essa advertência que Toquinha assume um lugar de sujeito que não quer se alienar mas, ao contrário, quer agir no mundo. E para isso pede ajuda.

Encontro nutrido nas viagens do Rio ao Córrego e gerado pelo desejo de juntas rompermos com a lógica que naturaliza o que não precisa ser. Encontro marcado de aprendizados mútuos e múltiplos. Encontro regido pela resistência a uma concepção de progresso que não dialoga com o passado e que vai gerando abismos entre as gerações. Encontro fundado na permissão e delicadeza para escavar as camadas de um solo de memória tão forte e abundante. Encontro tramado pela escuta das dores que o esquecimento pode provocar e pelo respeito ao silencio que às vezes prefere se instalar. Encontro escrito na parceria, na con-fiança.

Do Córrego dos Januários ao Rio de Janeiro... Encontro guiado por Janus Bifronte, o deus romano representado com duas faces contrapostas que expressam a possibilidade de olhar para a frente, o porvir, e ver atrás, o passado.

E vejam se resta alguma dúvida de que o nosso era mesmo um encontro marcado, no sentido benjaminiano. Pois vem de Janus, o deus das portas abertas, das passagens, do diálogo, da ponte entre mundos e realidades distintas a origem etimológica de Janeiro e Januário!

Olhar o passado para encaminhar outros futuros no aqui e agora. Era este o desejo de Toquinha ao enunciar seu apelo de memória. Segundo Jeanne Marie Gagnebin. ${ }^{14}$, "ouvir o apelo do passado significa também estar atento a esse apelo de felicidade e, portanto, de transformação do presente, mesmo quando ele parece estar sufocado e ressoar de maneira quase inaudível".

12 BENJAMIN, Walter. Magia e Técnica, Arte e Política. Obras Escolhidas I. São Paulo: Brasiliense, 1994, p.222-223.

${ }^{13}$ HALBWACHS, Maurice. A Memória Coletiva. São Paulo: Centauro, 2004, p.124.

${ }^{14}$ GAGNEBIN, Jeanne Marie. Lembrar Escrever Esquecer. São Paulo: Editora 34, 2006, p.12. 
Toquinha sabia disso e também tinha consciência que a tarefa não seria nada fácil...

Mas como nas histórias que povoaram a infância e o imaginário da escritora, quando a tarefa parece impossível, a ajuda vem. E assim, a Casa de Memória e Cultura do Córrego dos Januários inspirada na imagem alegórica de Janus Bifronte foi se materializando não só pelas vozes e histórias dos Januários, mas também pelas mãos de tanta gente que trabalhava para que aquele espaço tecido no entrecruzamento dos tempos fosse um espaço onde o apelo à felicidade do presente se fizesse ouvir.

Pois o apelo de felicidade maior dos Januários não é o de que a alegria do encontro não seja jamais soterrada?

A rememoração para Benjamin possibilita não só um diálogo com o passado, mas também com o presente, pois "não se trata somente de não esquecer o passado, mas também de agir sobre o presente". ${ }^{15}$

E é agindo sobre o presente, em diálogo constante com sua valiosíssima formação acadêmica, construindo pontes que ligam conhecimentos e experiências que vem $d o$ Córrego pro Rio e que também vão do Rio pro Córrego que Toquinha vem criando junto com os Januários um trabalho de beleza ímpar tendo como cenário principal o Clubinho de Leitura. Toquinha sabe que não basta a existência de um acervo literário para que os leitores se constituam. Possuidora de um rica experiência atravessada pela literatura, Toquinha deseja compartilhar sua paixão pelos livros como quem defende a convivência com Monteiro Lobato, Clarice Lispector e tantos outros, como um direito inalienável da vida.

Toquinha: A palavra abriu para mim as portas do mundo, de muitos mundos. E às crianças do Clubinho de Leitura eu sonho dar a conhecer estes mundos e ajudá-los a inventar mundos outros.

Eu sei que os livros são bons companheiros, mas isso para muitos é segredo. É preciso ajudá-los a desvendar mistérios nas entrelinhas, a apaixonarem-se por um texto por dentro das capas. Eu rio sozinha lendo as trapalhadas e as inteligentes tiradas da boneca Emília, personagem de Monteiro Lobato. Quanta personalidade para um boneca de pano! E os poemas de Drummond? Os textos de Clarice Lispector? O que dizer do poeta Manoel de Barros? E os poetas populares? E pela palavra e pelas cores eu conheci Frida Kahlo, e me emocionei... Eu só quero ajudar que as palavras se aproximem mais dos meninos da minha terra, e de outras terras também...

Em Maria de Lourdes Souza, a escritora e a educadora se uniram tornando-a ainda mais forte e potente para realizar seu sonho de "dar a conhecer estes mundos e ajudá-los a inventar mundos outros". Me emociono novamente ao pensar nas crianças e também adultos que cruzarão o seu caminho e de tudo de bonito e transformador que ainda está por vir...

Rio de Janeiro, 17 de fevereiro de 2014 Denise Sampaio Gusmão

As palavras de Denise me enchem de algo mais do que alegria, é satisfação por ter escolhido bons caminhos e ter chegado a um bom lugar. Acho que estão nascendo os "fiotinhos novos da tal de felicidade". E essa experiência comunitária

\footnotetext{
${ }^{15}$ GAGNEBIN, Jeanne Marie. Lembrar Escrever Esquecer. São Paulo: Editora 34, 2006, p.55.
} 
e poética tem me levado a cruzar fronteiras, a conhecer outros povos e compartilhar o que venho aprendendo.

Em setembro de 2013, fui convidada a estudar durante três meses na Facultad de Humanidades y Artes da Universidad Nacional de Rosário (UNR), cidade de Rosário/Argentina, através do intercâmbio entre a PUC-Rio e a UNR, com recursos oferecidos pela CAPES (Coordenação de Aperfeiçoamento de Pessoal de Nível Superior), contemplada com a bolsa de mestrado-sanduiche. Um novo capítulo surpreendente dessa narrativa começou a ser gestado. De um momento para outro me vi às voltas com minha primeira viagem internacional para fins de estudo. 


\section{Navegando por outros rios: bibliotecas populares de Rosário}

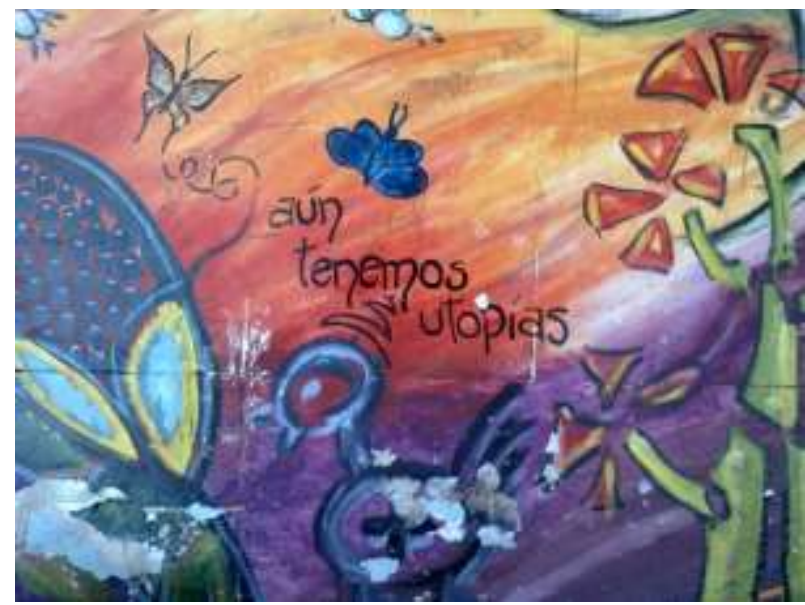

Figura 93: Aun tenemos utopias...

Quando a prof. Marília Rothier me convidou para fazer o mestradosanduiche na Argentina, suprindo a desistência de uma colega, eu mal pude acreditar. E me dei conta de que não sabia quase nada sobre aquele país além da histórica rivalidade no futebol, mas vi a possibilidade de conhecer uma nova cultura. E pensando na pesquisa que realizaria me ocorreu buscar contato com projetos de incentivo à leitura, modelos de gestão de bibliotecas e de lidar com o livro, com o texto literário. Eu tinha notícias de que Buenos Aires é famosa por suas muitas livrarias, e imaginei que tendo muitas livrarias também haveria muitos programas de promoção de leitura. A princípio me pareceu ousado planejar um trabalho de campo que demandaria deslocamentos, conversas com pessoas que eu não sabia como receberiam minhas indagações, mas, além de entrar em contato com uma nova cultura tendo a oportunidade de aprimorar o idioma, era o que me movia para ir a outro país, o que me interessava como pesquisadora.

Chegando em Rosário deparei-me com ruas charmosas, uma arquitetura linda, muitos parques, e o Rio Paraná gigante umedecendo por demais aquela cidade. A primeira semana foi para me adaptar ao modo de vida, acostumar à falta de engarrafamento, à eficiência dos ônibus urbanos que me permitiam cruzar a cidade em curto espaço de tempo, ao fato de que a cidade dorme entre $13 \mathrm{~h}$ e $16 \mathrm{~h}$. 
Surpreendentemente as pessoas foram muito receptivas, a UNR me acolheu. Estranhei muito, mas aos poucos fui me adaptando.

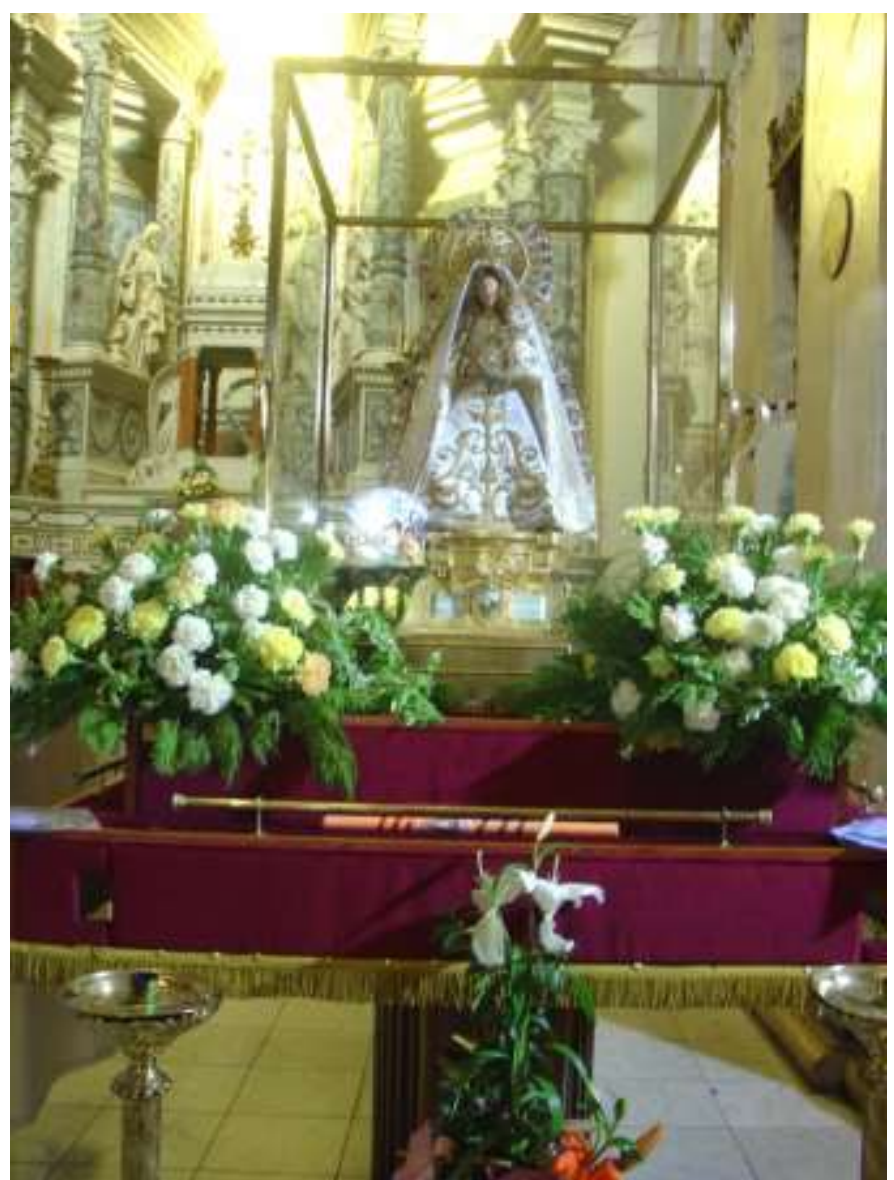

Figura 94: Pedindo a bênção a Nossa Senhora do Rosário

Meu projeto de pesquisa lá era basicamente entrar em contato com bibliotecas e outros órgãos que trabalhassem com promoção de leitura. Eu pensava em fazer entrevistas, conversar com quem levava os projetos a cabo, ainda que com todas as deficiências do idioma, apesar de conhecê-lo um pouco, eu me desafiava. Antes de começar os trabalhos eu agradeço a possibilidade de estar ali e peço a bênção de Nossa Senhora do Rosário em sua basílica.

Fui muito bem recebida pela professora Sandra Contreras coordenadora, pelo lado argentino, do convênio firmado entre a Pontifícia Universidade Católica do Rio de Janeiro (PUC-Rio) e a Universidade Nacional de Rosário (UNR), através do Projeto 057/11, que me mostrou a Universidade, me apresentou às pessoas a quem eu deveria me reportar e se colocou à disposição para quaisquer necessidades. Procurei o Prof. Dr. Gerardo Kahan, professor da Escuela de Ciencias de la Educación, que seria meu orientador, e na primeira reunião falei de 
minhas intenções como pesquisadora, no que ele foi atencioso me indicando pessoas com quem eu pudesse conversar, e lugares em que eu teria disponíveis materiais e informações relevantes para minha investigação.

Outro país, outra moeda, outra língua; lidar com tudo isso sozinha sendo a minha primeira viagem internacional em que tudo estava por minha conta e risco só não foi mais difícil porque fiquei morando com Circe Guedes, uma jovem brasileira que morava lá havia oito meses, e Prada, sua cadela cheia de manias. Circe me apresentou a cidade e seus modos de funcionamento. E Rosário aos poucos foi deixando de ser tão misteriosa.

Meu projeto se intitulou "Experiências argentinas em programas de incentivo à leitura". Meu interesse maior era conhecer projetos de promoção de leitura pelas periferias. Senti que minha estadia naquele país e a incursão pela Facultad de Humanidades y Artes - Universidad Nacional de Rosário - UNR, viria contribuir para o alargamento dos meus horizontes culturais e me proporcionar conhecimento de programas de leitura implementados na Argentina, principalmente os direcionados às populações fora dos grandes centros. O intercâmbio entre experiências que venho acumulando aqui no Brasil e as que tomaria conhecimento em Rosário, seriam de grande valia como inspiração para o trabalho de formação de leitores que já venho desenvolvendo e projetos que venho idealizando. Para narrar essa aventura na terra dos hermanos, decidi manter o curso dos encontros. Alguns dos projetos que conheci tornaram-se muito caros para mim; e ouso afirmar, ainda que tenha sido curto o tempo, que começamos a tecer uma rede que desconhece fronteiras.

As orientações do Prof. Kahan foram muito importantes, e eu comecei frequentar as charlas na faculdade, falar com professores, a visitar bibliotecas. $\mathrm{O}$ primeiro grande estranhamento, depois das siestas e do lidar diariamente com o idioma, foi ao utilizar as bibliotecas da faculdade, pois não se tem acesso direto ao livro. Os alunos têm acesso às fichas por autor ou por título e, uma vez com a ficha de identificação do livro desejado, se solicita ao bibliotecário. Parece óbvio, mas eu não sabia o que procurar, queria pegar o livro na estante, folhear para saber se me servia, se me interessava. Eu queria ler os autores argentinos que escreviam sobre os temas que me interessam, mas eu não sabia quais eram, e me vi perdida. Comecei a assistir uma aula aqui, outra ali. E, seguindo as orientações 
do Prof. Kahan, fui visitar a Biblioteca Argentina Dr. Juan Àlvarez, referência na cidade, e por sorte/surpresa/alegria ou ajuda dos anjos protetores dos pesquisadores, quando cheguei, conversando com a bibliotecária e querendo saber se havia um espaço dedicado à literatura infanto-juvenil, fui informada que ficava no piso superior e que dentro de meia hora começaria o encontro com a autora argentina Silvia Schujer, renomada escritora de literatura infantil e juvenil. A palestra fazia parte do Plan Nacional de Lectura. O evento era aberto ao público e gratuito. Aí comecei a descobrir os autores de literatura e os teóricos que me interessariam ler. $\mathrm{O}$ mundo da literatura argentina para crianças e adolescentes começou a se abrir. Destes encontros com autores oferecidos pelo Plan Nacional de Lectura, ainda tive a felicidade de presenciar a palestra de Sandra Comino, também importante escritora de literatura infantil e juvenil e de teoria sobre o assunto, também na Biblioteca Argentina; e do encontro com Juan Sasturain, conhecido escritor e jornalista, na cidade de Santa Fé.

Depois disso procurei a professora Jaquelina Miranda, que ministrava o seminário La importancia de la literatura en la primera infancia, da qual eu participei de duas aulas, que muito generosa fez uma lista com os principais autores argentinos para crianças e adolescentes com os quais ela vinha trabalhando e/ou que são importantes na Argentina. A primeira faísca de luz.

Foi meu primeiro contato com uma biblioteca fora da faculdade, mas que funcionava com o mesmo sistema das fichas, sem acesso direto ao livro mesmo na seção infantil. Fui informada ainda de que a instituição tinha site próprio e estava nas redes sociais, no caso o facebook, onde eu teria acesso a muita informação. Minha próxima visita seria à Biblioteca Pedagógica "Eudoro Díaz", recomendada pelo meu orientador. Como eu havia entendido que as bibliotecas, quase todas, têm sua página nas redes sociais, fui buscar pela Eudoro Díaz no facebook. Encontrei facilmente, e pesquisando nos seus posts fiquei encantada com as fotografias dos trabalhos realizados. Um dos posts era o convite para um Encuentro de formación, na Biblioteca Popular Cachilo, uma atividade do Plan Nacional de Lectura. O encontro estaria a cargo de Beatriz Actis.

Eu não conhecia o trabalho da escritora, mas, entrando no facebook da referida biblioteca, pude ver os comentários felicitando a instituição pela 
oportunidade, e davam conta de que a escritora era muito reconhecida por seus trabalhos como autora e como tallerista do Plan Nacional de Lectura.

Entrei em contato com a biblioteca através do correio eletrônico divulgado

Hola,

yo soy Maria de Lourdes, de Brasil, y estoy acá en Rosário por 3 meses para intercambio por la maestria en UNR. Mi tema de investigación es: los planes de promoción de lectura y las bibliotecas. Me pareció mui importante participar del "Encuentro de formación" em tu instituición. Me gustaria mucho participar, se puede? Como hago? Hay que inscrivirse? Hay que pagar?

Por favor, me envien información.

Gracias por la atención.

Saludos

E me responderam prontamente.

Hola Maria de Lourdes

El encuentro de mañana viernes es el último por este año, pero puedes asistir, No tiene costo.

Es de 14 a 17 horas. Necesitamos que envíes a este mismo correo tu nombre completo y número de documento.

La dirección de nuestra biblioteca es:

Virasoro 5606 (Presidente Perón al 5600), en la zona oeste de Rosario.

Muchos saludos.

Assim comecei minha busca pelos bairros mais periféricos. Todas informações necessárias para chegar até lá eu tive que buscar com os responsáveis pela própria biblioteca, que foram sempre muito atenciosos. Lá, como aqui, os alertas para os possíveis perigos ao embrenhar por zonas mais afastadas, perto de favelas, das villas rosarinas, eram constantes. Mas sempre me informavam desde como chegar de taxi ou de ônibus até as recomendações como: cuidado com a bolsa, aqui é perto de favela, melhor não vir à noite, etc., todas já muito comuns a minha própria experiência de morar em Padre Miguel-RJ, pero da Vila Vintém e do Sete-sete, conhecidas áreas de pobreza e violência. Assim define Claudia Martinez, coordenadora da biblioteca que sempre responde às minhas mensagens por e-mail ou pelas redes sociais, o bairro onde se encontra a instituição.

Villa Urquiza, en la zona oeste de Rosario, rodeado de villas de emergencias, planes habitacionales (FONAVI) barrios trasladados. Zona fragmentada y con una problemática social aguda, además de muchas inseguridad y violencia. 
Das bibliotecas visitadas destaco algumas por ter me aproximado mais de seus trabalhos. São elas: Biblioteca Popular Cachilo, Biblioteca Popular y Municipal José Hernandes, Biblioteca Popular Juan Bautista Alberdi, Bibliomovil e Biblioteca Independiente para el pensamiento amplio, crítico y poético. Alguns registros fotográficos dizem muito das muitas possibilidades que oferecem uma biblioteca.

Antes de levá-los às bibliotecas por onde passei, é preciso apresentar a CONABIP (Comisión Nacional de Bibliotecas Populares), que é um órgão do governo que apoia ações das bibliotecas populares argentinas.

La CONABIP lleva adelante su misión por medio de la realización de acciones para la promoción de las bibliotecas populares, la compra y envío de libros, el incentivo a la lectura y la distribución de subsidios.

En el desarrollo de políticas específicas retoma planes y programas ya implementados por la CONABIP y los elaborados por las bibliotecas populares y diferentes provincias, respetando las diversidades regionales y locales. Cada proyecto emprendido constituye una respuesta planificada a las necesidades de las bibliotecas y las de sus usuarios. (Fonte: http://www.conabip.gob.ar/vpes/491 )

A CONABIP atua com planos e programas como: Plan Nacional de Lectura en las Bibliotecas Populares, Plan Nacional de Capacitación para las Bibliotecas Populares, Plan Nacional del Libro, Plan Nacional de Inclusión Digital, Programa de Información Ciudadana, Programa de Subsidios. Estas ações buscam fomentar os projetos criados pelas bibliotecas populares e incluí-los na rede dos programas oficiais do governo através da Secretaria de CulturaPresidência de La Nación. Importante salientar que existe o Plan Nacional de Lectura, ação do governo federal argentino, que por todo país oferece uma gama de oficinas de capacitação para os professores e profissionais de bibliotecas, encontros com escritores, pesquisas, dentre outros. E o material literário, audiovisual, está on line; riquíssimo material disponível para quem necessite. Quando procurei a prof. Maria Luisa Miretti, coordenadora do programa de Mestrado em Literatura Infantil da UNR, que ministrava um dos seminários que frequentei, e que coordena também os trabalhos do Plan Nacional de Lectura da região 4, que compreende a Província de Santa Fé, ela me disse: está tudo na internet, é só entrar no site do Plan Nacional de Lectura e está tudo lá. Mas eu queria ver o material disponibilizado, ter acesso aos livros, entender como funcionava, o que achava difícil devido ao pouco tempo disponível, e nem 
cheguei a cogitar que o conteúdo (livros, textos, vídeos, etc. ) estivesse disponível, mas quando busquei o site, realmente estava tudo lá. Vídeos, livros literários e pedagógicos em PDF, notícias das atividades desenvolvidas. Também se distribui livros para as escolas. As fotos abaixo mostram o material literário enviado pela Presidencia de la Nación que acabara de chegar à biblioteca do Instituto Superior del Profesorado $N^{o} 16$ "Dr. Bernardo A. Houssay", onde fui recebida pela Prof. Maria Elena Micheli e pelas bibliotecárias Liliana e Ema.

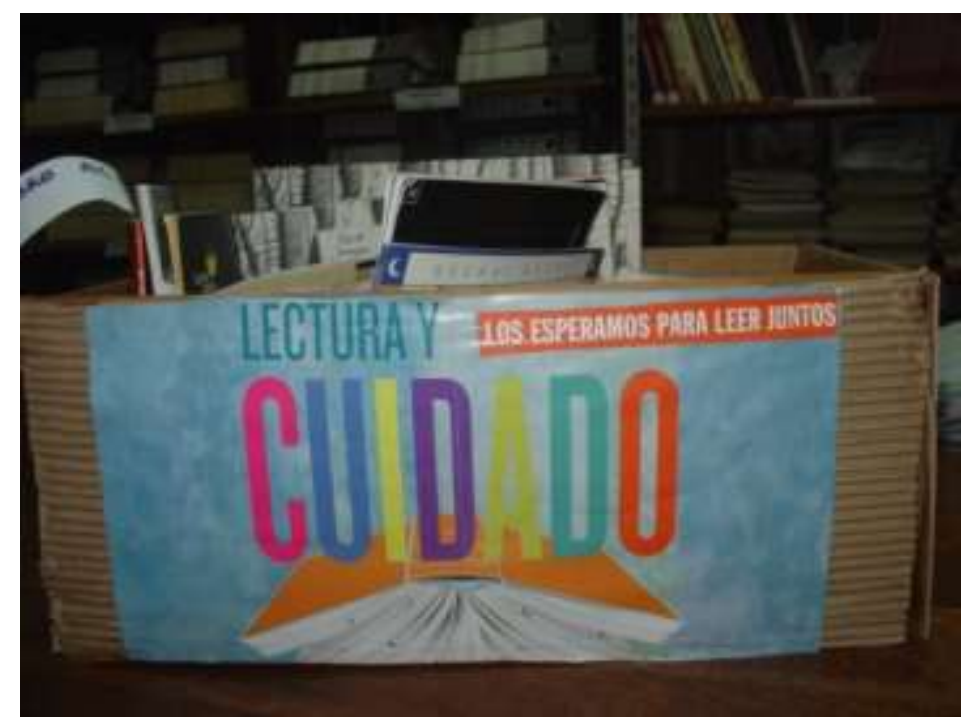

Figura 95: Caixa de livros enviados às escolas argentinas pelo Plan Nacional de Lectura

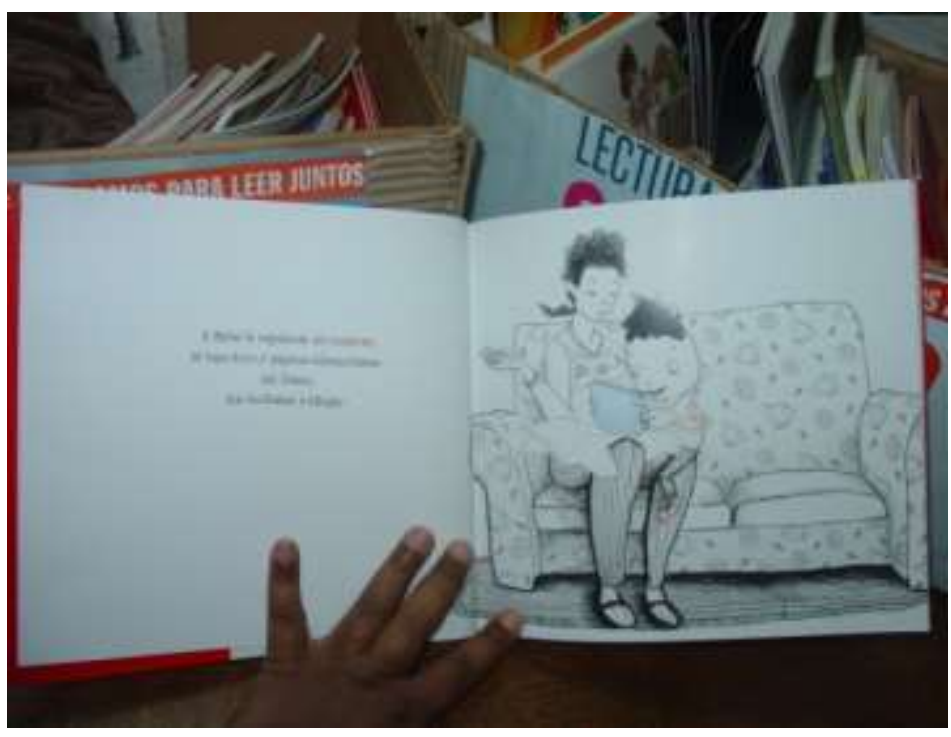

Figura 96: Livro-álbum

Agora sim, vamos às bibliotecas! 


\section{1}

\section{Biblioteca Popular Cachilo}

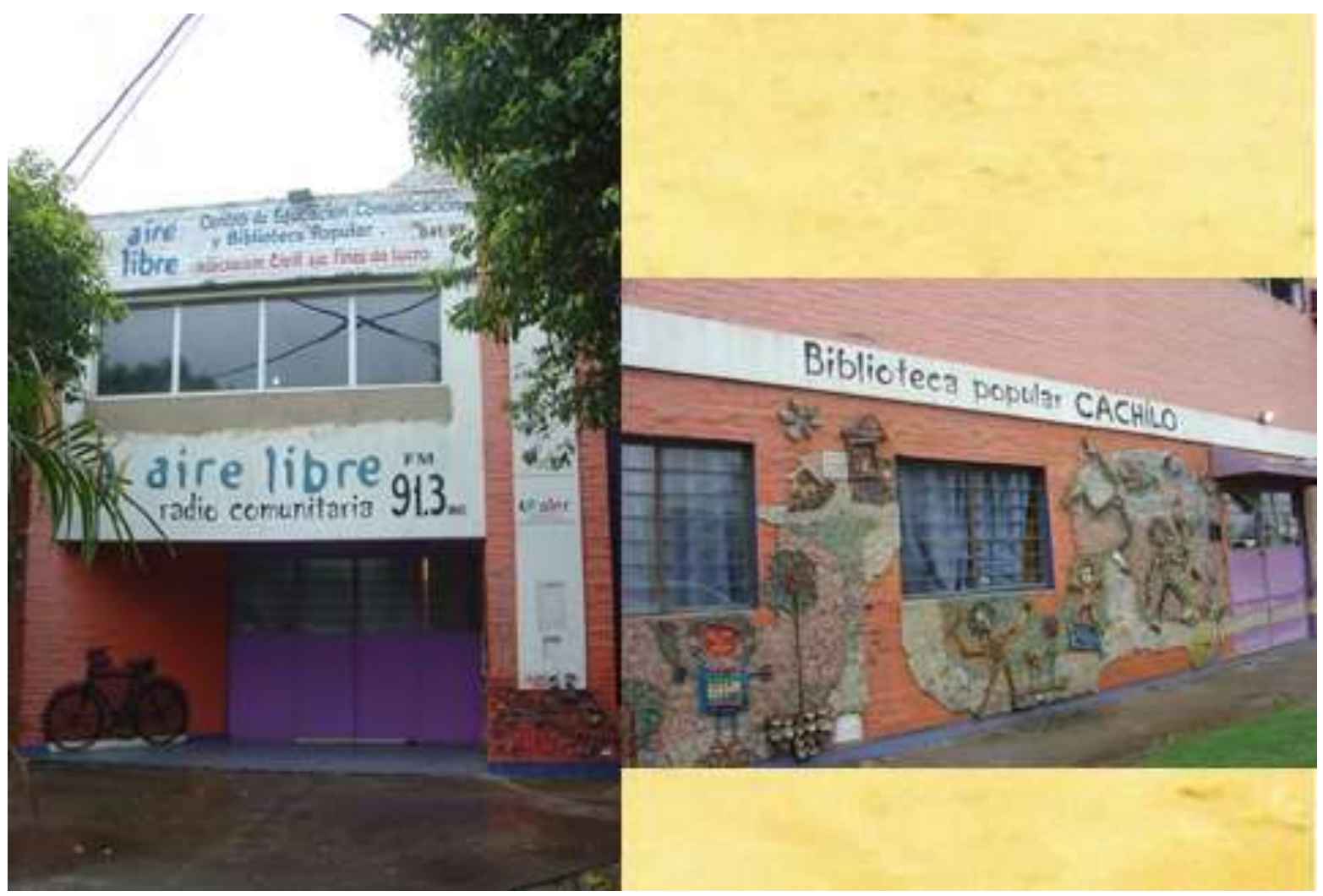

Figura 97: Biblioteca Popular Cachilo 1

Figura 98: Biblioteca Popular Cachilo 2

A Biblioteca Popular Cachilo viria a abrir novos horizontes, expandir minhas expectativas por conhecer projetos inovadores no modo de trabalhar com livro, promover a leitura. Era o último encontro pelo Plan Nacional de Lectura na Cachilo. Grata surpresa. No bairro Villa Urquiza, afastado do centro, me deparei com um lugar de trabalho com múltiplas formas de arte. Um sobradinho de esquina que impressiona desde colorido da fachada com os mosaicos feitos pelas próprias crianças, realizado por um dos muitos talleres oferecidos, que me encheu os olhos. Fui muito bem recebida pelas responsáveis pela biblioteca e naquele dia tive muitos aprendizados. O contato com Beatriz Actis foi a oportunidade de conhecer alguém que trabalha auxiliando professores, bibliotecários e quem mais queira, a descobrir os "mistérios" guardados dentro dos livros. O trabalho era experimentado na prática. Pude ouvir a leitura de alguns contos como 


\section{La Pilaraña ataca por primera ¿y última? vez, de Beatriz Actis}

Cuando tiene hambre, la Pilaraña (que es un bicho horrible) silba. Ni abre la boca, ni le hace ruido la panza ni se le junta saliva entre los dientes. Silba para despistar...

Siempre anda por ahí algún Cascaroso distraído, de ésos que a la Pilaraña le gustan tanto, y se para a escuchar cómo la monstrua se silba un tango.

Entonces ella lo engancha del cuello del saco con una uña y se lo acerca a los anteojos para estar bien segura de que es un Cascaroso en buen estado, y se lo come. Sin masticar.

Por suerte, todos los Cascarosos (grandes y pequeños, raquíticos y obesos, sabihondos e ingenuos, santafesinos, cordobeses, porteños y de donde fueran) han hecho el Curso Práctico de Supervivencia en Panza de Pilaraña.

Una vez tragado por la Pilaraña, el Cascaroso prende un fósforo mientras cae por el esófago y ya en la panza abre el manual de bolsillo con las principales instrucciones:

"1ro. Encender un fósforo;

2do. Abrir el manual;

3ro. Leer el punto 4".

"Uf", piensa el Cascaroso adentro de la panza.

"4to. Tragar mucho, mucho aire y después soplar, en lo posible, en forma de estornudo".

Cascaroso estornuda, y el fósforo se apaga. Todo es oscuridad y silencio. Hasta que empieza a oírse un retumbar de cascos de caballos, de soldados montados, de ejércitos... (Los Cascarosos tienen mucha imaginación). Pero es la Pilaraña que empieza a reírse por la cosquilla interior. Y se ríe tanto, tanto, y abre tanto la boca para reírse que el Cascaroso trepa y salta, y ya está de nuevo en el mundo, sacudiéndose la ropa y acomodando en su bolsillo el práctico manual. nomás.

Después se escapa lo bastante lejos como para que no vuelvan a atraparlo así

Mientras tanto, a la Pilaraña se le pasa la risa y se pone a llorar. Secándose las lágrimas, camina hasta el kiosco de la esquina y se compra un libro que se llama: "Cómo ser burlada por un Cascaroso y no sentirse una pavota". Se sienta en un banco de la plaza y se pone a leer.

(Fonte: http://bibliopequeitinerante.blogspot.com/2012/11/cuento-la-pilaranaataca-por-primera-y.html)

Depois da leitura foi a vez de lidarmos com a história, se me recordo bem, assumimos os papéis dos personagens e cada um defendia seu ponto de vista. Era a primeira vez que eu participava de um trabalho daquela natureza tendo que me comunicar com as pessoas que faziam parte do meu grupo, mas funcionou. Suas ideias de como trabalhar literatura em sala de aula e em outros espaços, a apresentação de vários livros e suas possibilidades de entrada, de desvendar as entrelinhas e porpor atividades era bastante interessante. Em seu livro "Las aulas de literatura: de los textos a las teorias y de la teoria a los textos", Beatriz fala do conceito de laboratorio de lecturas y escrituras. 
El concepto de laboratorio de lecturas y escrituras retoma la ya habitual noción de taller en un intento por resignificarla, recuperando las notas que inicialmente fueron definitorias del aula-taller y que en ocasiones parecen haberse diluido o anquilosado: la manipulación directa de materiales, y también las investigaciones, experimentos y juegos colectivos en los que "poner el cuerpo" resulta esencial a la hora de construir teoria a traves de la practica. (ACTIS, 2013, p. 15)

Mostrou possibilidades de se trabalhar com o livro, que ainda não vi traduzido para o português, Rey y Rey, das autoras escocesas Linda De Haan e Stern Nijland, uma história de um príncipe que se apaixona por outro príncipe, e que trata das questões do homossexualismo de forma bastante lúdica.

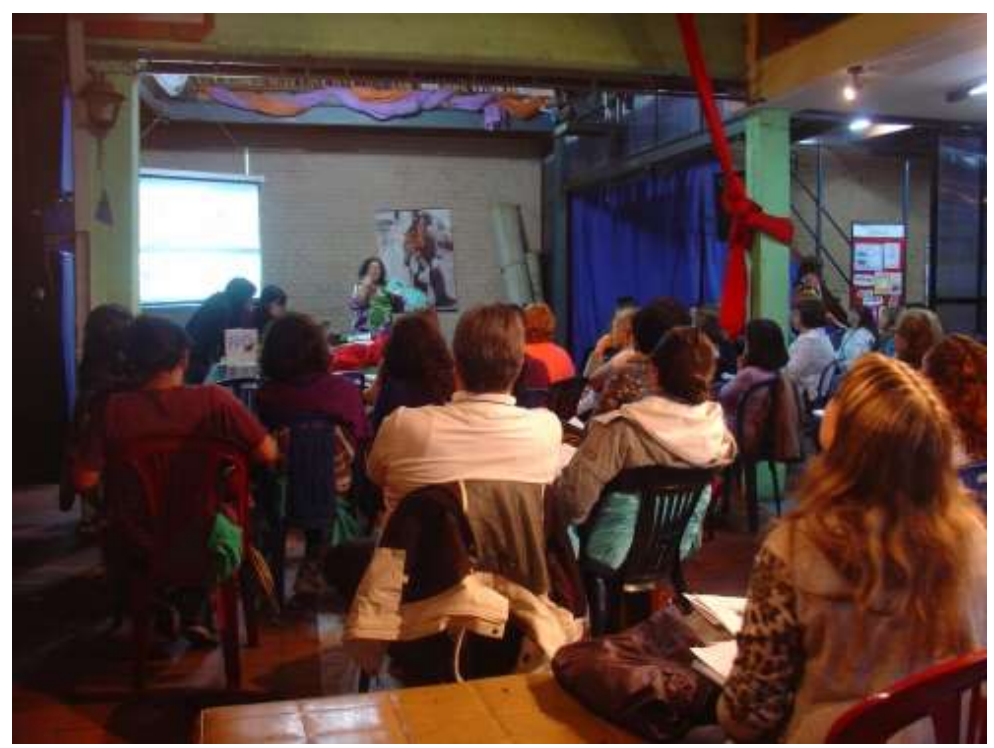

Figura 99: Taller Beatriz Actis

E em seu livro apresenta propostas de trabalho com literatura, como por exemplo:

(...) Proponemos algunas actividades de escritura: tomamos un tema de interes en la infancia y/o en la literatura de la infancia, ejemplo: personajes de Las mil y una noches y/o de cuentos maravillosos (hadas, duendes, dragones), monstruos, piratas, estrellas de circo, aventureros en paises lejanos, etc., y escribimos: poesia, diálogo teatral, cuento breve descripción, biografia, reportaje imaginario...

Producimos al menos una versión (breve) de um cuento de la tradición oral cenroeuropea. Elegimos escribir una versión clásica, o bien paródica. tambien, podemos tomar un personaje tradicional y incluirlo en una trama diferente a la original aunque necesariamente paródica, entre otras versiones posibles de la actividad propuesta. (ACTIS, 2013, p. 49)

\section{Cenicienta no quiere estar aqui!}

Beatriz Actis

El problema de cenicienta es su grandisima distración. 
Pierde el plumero, pierde el trapo de piso, pierde la escoba.

En realidad, esto sucede porque ella piensa que:

el trapo es la alfombra mágica de Aladino;

la escoba, un trasporte de bruja como la de Hansel y Gretel;

el plumero, una palmera encantada a la que trela para encontrar a la gallina de mos huevos de oro...

Y, tan atrapada está por su propia disctracción, que no solo extravia los elementos de limpieza (el trapo-alfombra termina, por ejemplo, entre los techos, junto a la escoba que cree voladora) sino que se siente casi todo el tiempo fuera de la realidad, dentro de un cuento de hadas.

Sin embargo, su distracción - que su madrastra y su hermana consideran um terrible defecto - es la que la hace liberarse del maltrato al que la someten em su casa.

Como todos sabemos, es príncipe da una fiesta em su palacio. Alli espera encontrar a una muchacha buena y convercerla para que sea su esposa.

La madrina de Cenicienta le consegue um traje hermoso y um carruaje ágil para asistir la fiesta.

Ella y él bailan toda na noche.

A las doce, y siempre por su eterna distracción, Cenicienta parte del palacio y deja olvidado algo.

Esta vez no es en el techo si no en las escaleras.

$\mathrm{Y}$ en esta oportunidad, el zapatp perdido no es la ruina de Cenicienta sino su salvación.

Gracias a él, el principe puede encontrarla, dejar de lado a las parientes malvadas y compartir la vida con Cenicienta hasta el fin de los tiempos.

Ahora, son los criados del castillo los que se quejan, porque la nueva princesa olvida por qualquer salón, por qualquer rincón: la corona del marido, el cetro del suegro y hasta el trueno de la suegra...

Es que la siempre distraida Cenicienta imagina que:

el cetro es un bastón de reina mala disfrazada de viejita que busca a Blancanieves por el bosque;

el trono es la cama en que Ricitos de Oro descansa de su fatiga em casa de los osos;

la corona es un nuevo recurso de Caperucita para adornar su cabeza, cansada de que el lobo la reconosca por su llamativa caperucha roja.

Y de este modo, perdida en su mundo de cuentos, Cenicienta parece estar diciéndonos otra vez: "no quiero estar aqui!" (ACTIS, 2013, p. 49-50)

Com Actis eu ainda participaria do taller de lectura y escritura que ela oferece em sua residência, me permitindo entrar em contato com outros apaixonados por literatura, novos escritores que me acolheram no grupo e me encorajaram a escrever em outra língua; e me dei conta de que conseguia, com muitos problemas, claro, mas eu já podia pensar e me comunicar em outro idioma. Isso era um avanço. A escritora se colocou à disposição para intercâmbio, para ajudar-me em questões que julgasse necessárias. Para nos despedirmos a escritora me convidou, em meio aos seus muitos afazeres de fim de ano, para um café no 
"El Cairo", típico bar rosarino. O "povo das artes" me pareceu sempre muito “acessível”, disponível para conversas.

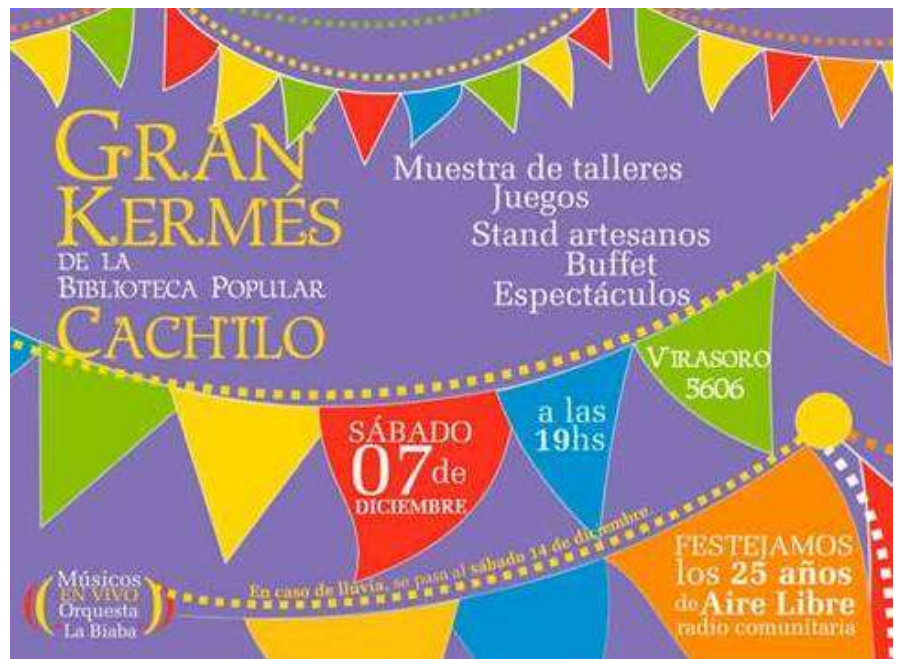

Figura 100: Divulgação da Quermesse

Voltei à Cachilo três vezes, e fui me dando conta do extenso trabalho social que a equipe desenvolve tendo como carro-chefe a literatura. Minha última visita foi no dia da quermesse.
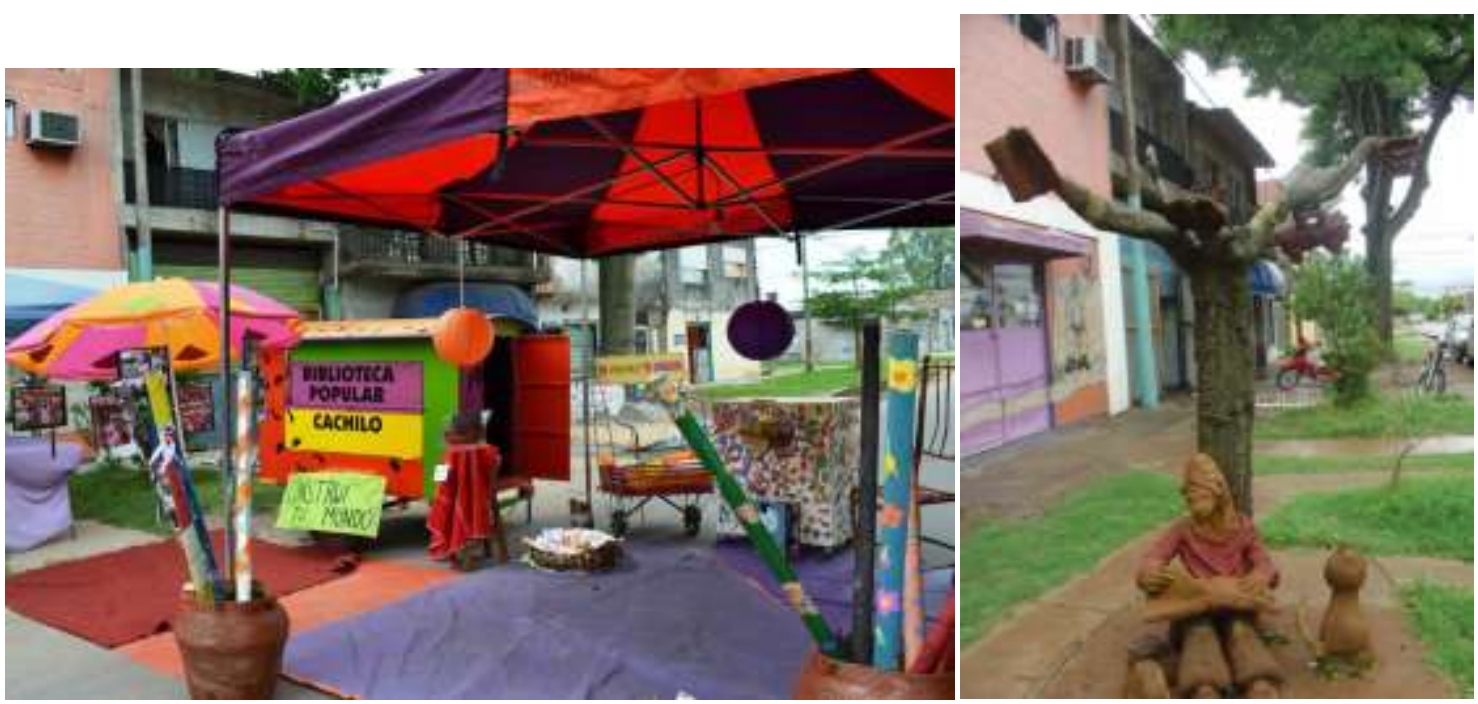

Figura 101: La Cachilo te cuenta 1 (Foto de Victor Bobadilla) Figura 102: Leitura ternura 


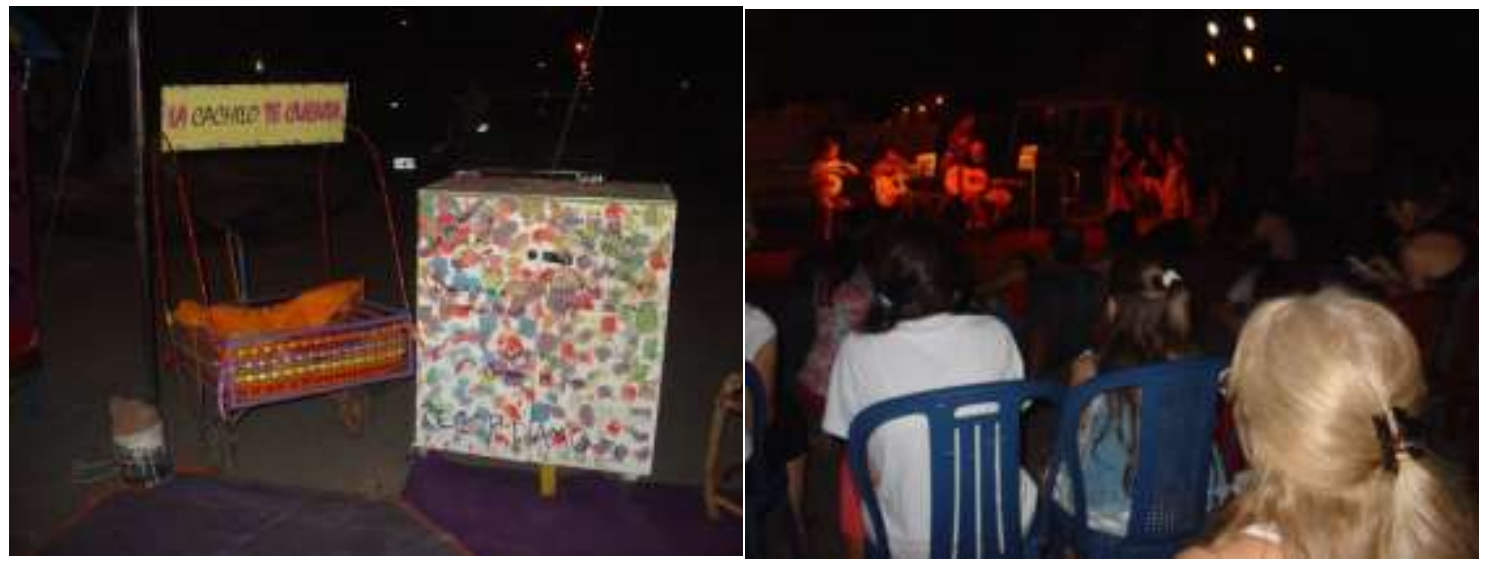

Figura 103: La Cachilo te cuenta 2 (Foto de Victor Bobadilla)

Figura 104: La kermess

Nessas andanças pela calle Virasoro 5606, eu conheci um dos projetos desenvolvidos chamado "La Cachilo te cuenta", que é quando a biblioteca se desloca para ruas próximas. Claudia Martinez, coordenadora da biblioteca, conta que inicialmente faziam oficinas nas calçadas com a licença dos vizinhos. Depois se deram conta de que precisava um processo de trabalho, e então começaram a ficar, semanalmente, em pontos fixos nas calçadas que ceden amablemente los vecinos, e onde acontecem talleres de lectura y arte; percebendo a necessidade de levar a arte para a rua, incorporaram o projeto de artes plásticas "Pintar para leer" em que pintavam murais nas casas e instituições, mais tarde incorporaram teatro e expressão corporal.

Em 2013, segundo Martinez, sentiram que era preciso alcançar bairros mais distantes; e criaram o Expreso Cachilo, que é um tráiler- tren de libros que levam aos domingos a praças, parques e instituicões da cidade.

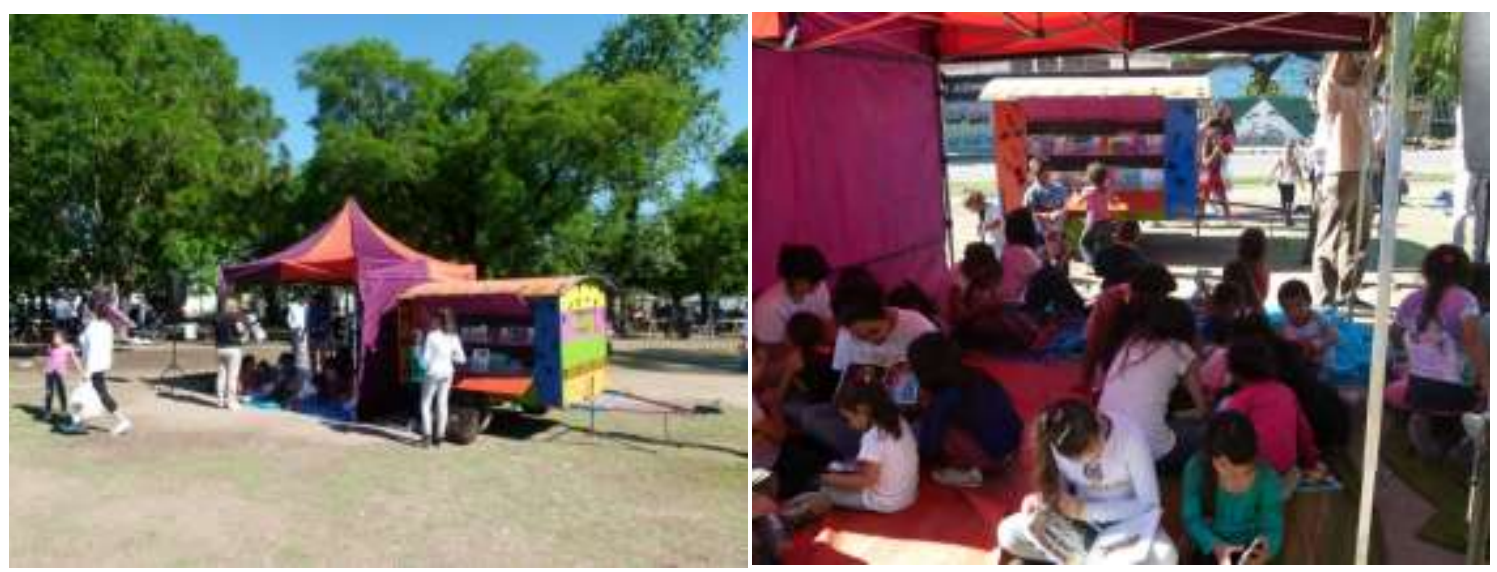

Figura 105: La Cachilo te cuenta no bairro de Ludueña 1

Figura 106: La Cachilo te cuenta no bairro de Ludueña 2 (Fotos de Victor Bobadilla) 
Curiosa por saber a origem do nome Cachilo, Claudia Martinez me esclarece que Cachilo foi um poeta rosarino conhecido como Poeta de los muros, e seu nome verdadeiro era Higinio Alberto Maltaneres. E me parece conhecendo um pouco mais do poeta que perambulava pelas ruas, que ele buscava a liberdade fazendo poesia, escrevendo nos muros; penso que foi uma justa homenagem.

Além das oficinas, também emprestam livros por onde passam. E assim $L a$ Cachilo vai encantando as ruas da Zona Oeste de Rosário... e deixando ver, de forma concreta, o que pode a literatura criar, seja onde for, desde que se tenha vontade; que ela é uma entre outras artes que se complementam, que permitem voos, que possibilitam resssignificações e enchem os olhos de muita beleza. Explosão de criatividade!

5.2

\section{Biblioteca Popular Juan Bautista Alberdi}

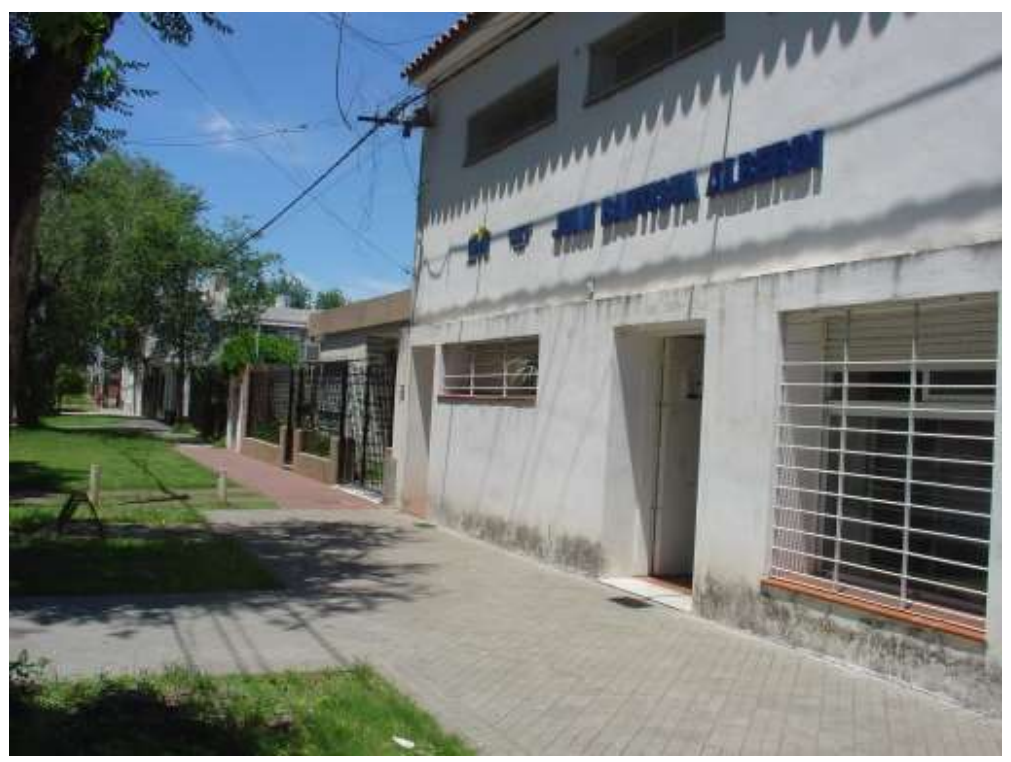

Figura 107: Biblioteca JB Alberdi

Eu vinha buscando o endereço de uma biblioteca que diziam ficar perto da casa onde fiquei hospedada, pessoas da própria Cachilo haviam me indicado, já que era de fácil acesso, mas eu não conseguia o endereço correto. Sabia que era nas proximidades do bairro Arroyito, Zona Norte de Rosário, mas se mantinha uma incógnita. Num sábado de manhã, bisbilhotando o facebook de algumas bibliotecas, vi que a $J B$ Alberdi estava on line, enviei então uma mensagem para 
ver se alguém me respondia dando finalmente a informação que vinha se cercando de um certo mistério... Por sorte alguém me respondeu, era Graciela Diez. Bibliotecária aposentada que agora era voluntária na Biblioteca Popular Juan Bautista Alberdi. Trocamos breves mensagens.

30 de novembro de 2013 09:53

Maria de Lourdes

Hola Graciela, soy Maria de Lourdes, de Brasil y estoy acá haciendo una investigación por el intercambio con UNR desde PUC-Rio en Rio de Janeiro/Brasil. Conoci algunas bibliotecas y me gustaría conocer el trabajo de uds. Mi tema de investigación es conocer los planes de promoción de lectura y el trabaho de las bibliotecas. Gracias por la atención. Saludos

\section{Graciela Diez}

Bárbaro, te esperamos en la biblioteca. Yo soy bibliotecaria jubilada y ahora soy colaboradora en esta biblioteca. Ahora voy para allá, estaremos hasta las 11.30, quizás puedas ir. Es un cierre de talleres y ahora será con niños, yo tengo un libro objeto hecho con cosas encontradas en los libros y lo tomo como una forma de empezar a contactarse con ellos. Te esperamos, si no estás lejos ojalá puedas ir ahora. Nos vemos...

\section{Maria de Lourdes}

Bueno, muchas gracias, me voy. Me gusta ver los cierres de talleres...

Gracias...

\section{Graciela Diez}

Buenísimo...

Uma hora depois eu estava na biblioteca. Fui até a recepção, me apresentei, e procurei por Graciela. Com a amorosidade que lhe é peculiar ela, que estava próximo, se identificou; me apresentou a Amanda Paccotti ${ }^{16}$, professora aposentada, pesquisadora do trabalho das irmãs Cossettini, que também é voluntária na JB Alberdi que se mostrou também muito amável e contente com minha visita; e me fizeram sentir-me em casa. Foi um novo lindo encontro. Graciela contou a história de seu livro-objeto que me deixou muito emocionada.

16 Amanda Paccotti é professora aposentada. Foi uma das pessoas que fizeram o Instituto Fisherton de Educación Integral, onde foi diretora. Entre 1988 e 1990 trabalhou como documentarista no Instituto Rosario de Investigaciones en Ciencias de la Educación (IRICE) para ordenar e classificar o material pedagógico da Escuela Carrasco. Ali entregou o grupo realizador do filme La escuela de la Señorita Olga. Em 1992 publicou o fascículo Olga Cossettini y La Escuela Serena, sobre a mesma experiência. Atualmente é colaboradora externa ad-honorem da IRICE e integra o Grupo de Amigos do Arquivo Cossettini, que cuida do arquivo das irmãs Cossettini. E hoje é voluntária na Biblioteca Juan Bautista Alberdi (Fonte: http://redaprenderycambiar.com.ar/perfiles/amanda-paccotti/) 
Com os pedacinhos de papel, fotografias, notas fiscais, marcadores de livros e outros objetos encontrados dentro dos livros que chegam à biblioteca por meio de doações, Amanda Paccotti a havia pedido que os aproveitasse de alguma forma, e ela decidiu criar um livro caseiro, delicado e muito eloquente.

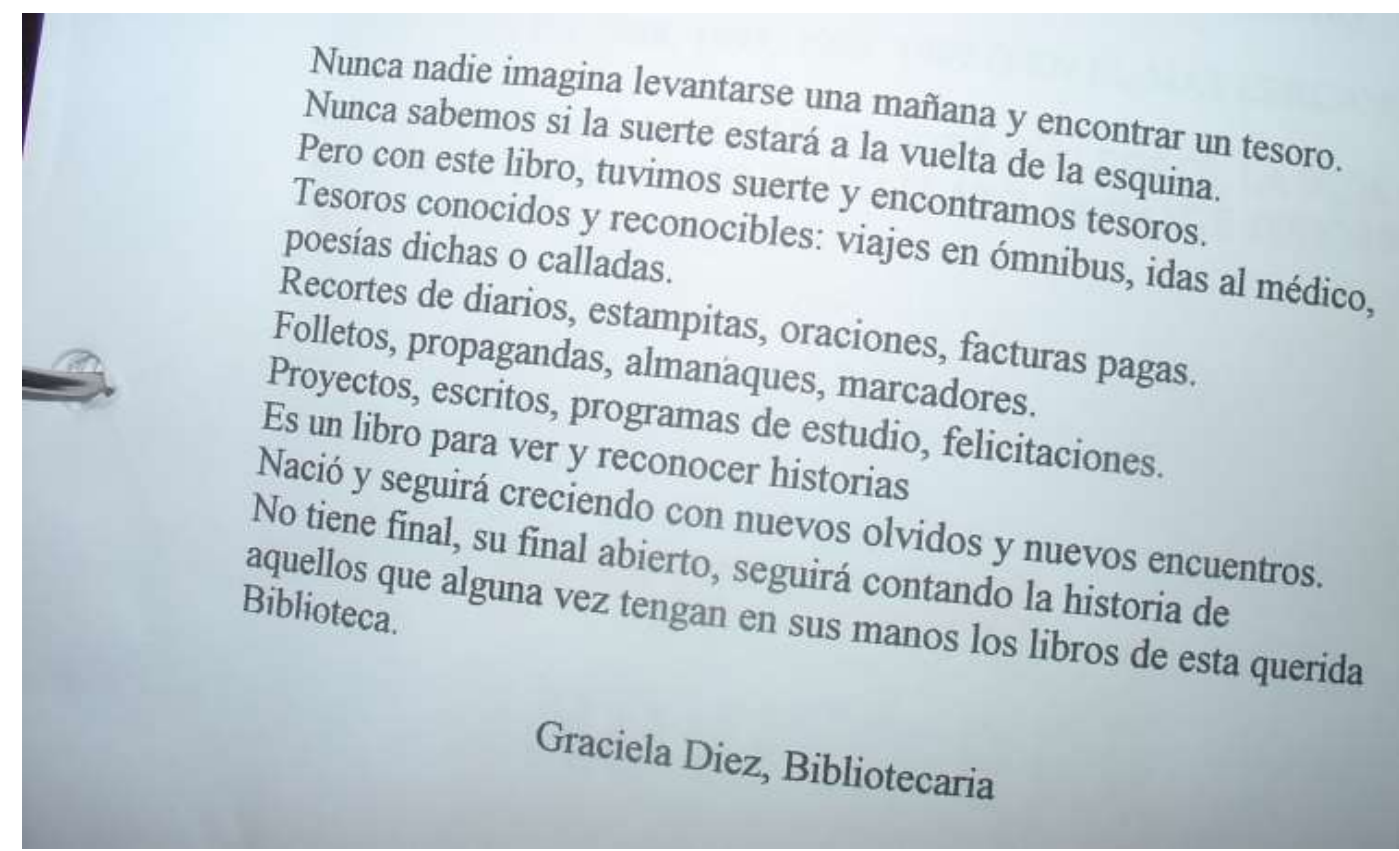

Figura 108: Apresentação do livro-objeto de Graciela Diez
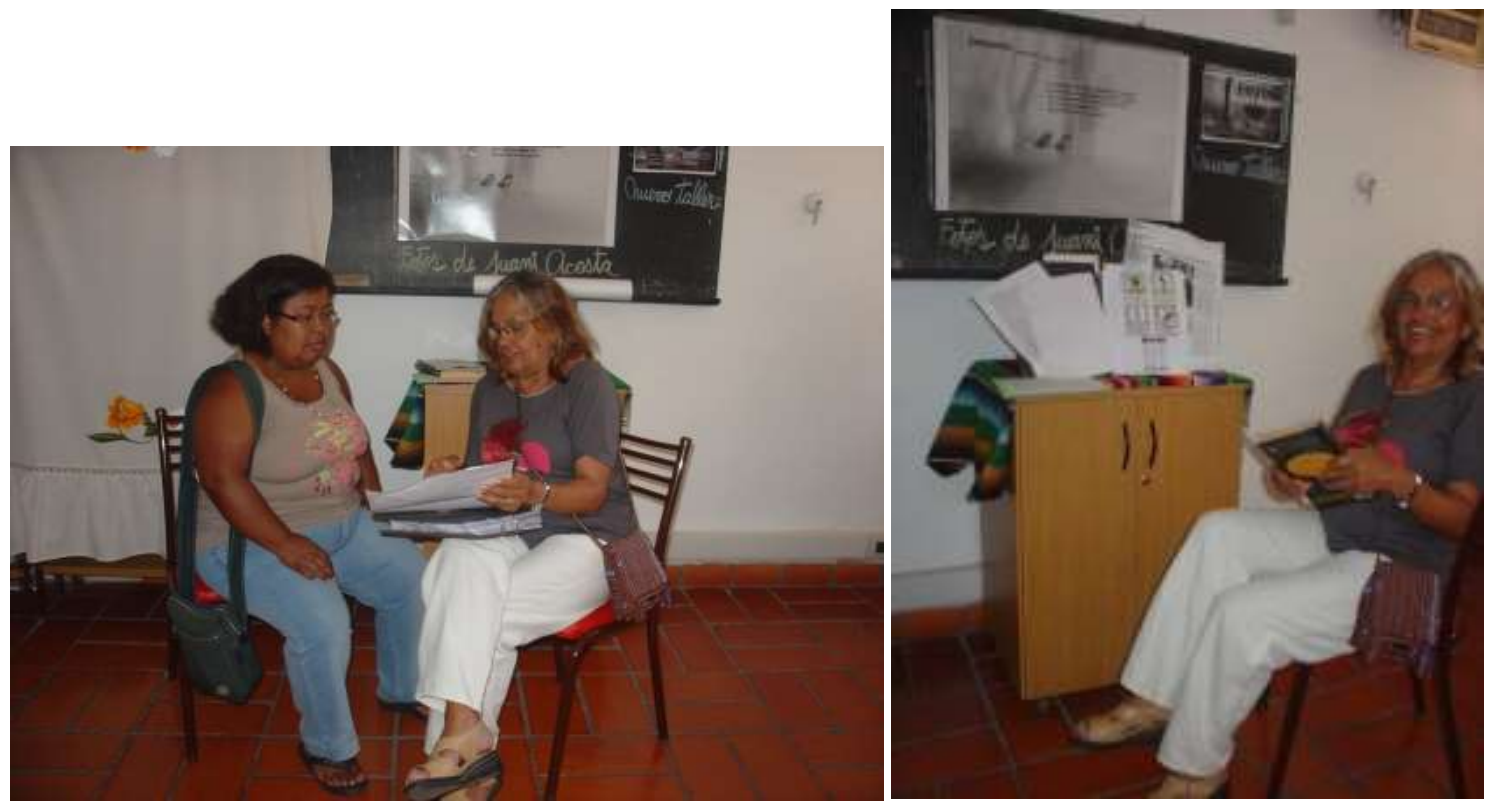

Figura 109: Toquinha e Graciela Diez

Figura 110: Graciela Diez e seu livro-objeto

Em dado momento estávamos, eu e Graciela, no andar superior vendo a exposição dos trabalhos realizados nos talleres oferecidos na biblioteca, quando 
um rapaz com uma criança no colo pergunta: quem é a brasileira que está visitando a biblioteca? Não entendi muito bem a situação, pensei que tivesse esquecido a bolsa ou a tivesse perdido alguma outra coisa, me identifiquei, e então ele me disse que me aguardavam no salão do primeiro piso para iniciarem a apresentação do taller PALABREANDO, la lectura com y de los niños. Fiquei muito surpresa com aquele cuidado, com a delicadeza de me esperarem para iniciar os trabalhos; me senti muito respeitada, reconhecida na minha função de pesquisadora.

Claro, atendi ao chamado e desci. Amanda estava sentada com uma criança no colo, era Emilia Casadedio, uma menina linda de oito anos, que participara do taller PALABREANDO em que as crianças eram estimuladas a escrever contos a partir de palavras. Emilia era uma pequena escritora lendo seu texto. O carinho de Amanda, a atenção de todos os ouvintes e a concentração daquela nena, eram qualquer coisa de emocionar demais...

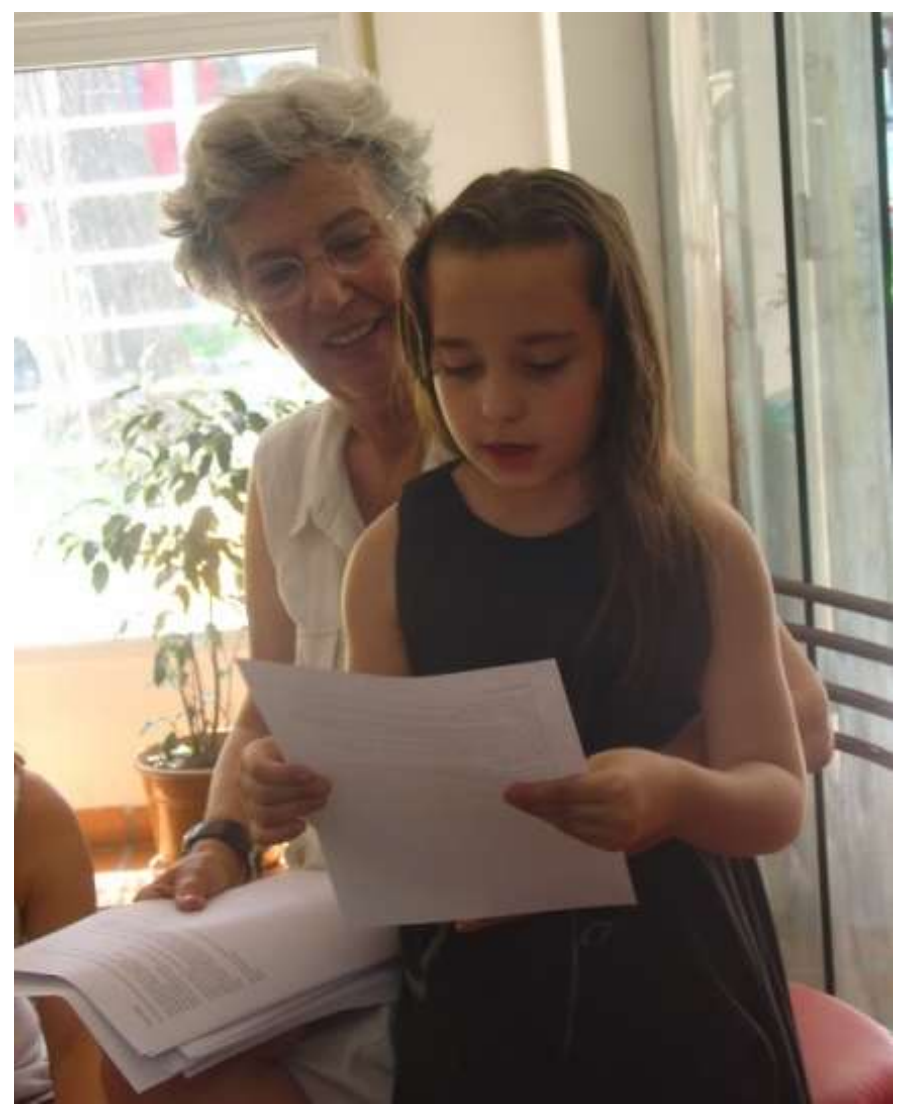

Figura 111: Amanda Paccotti e Emilia Casadedio 


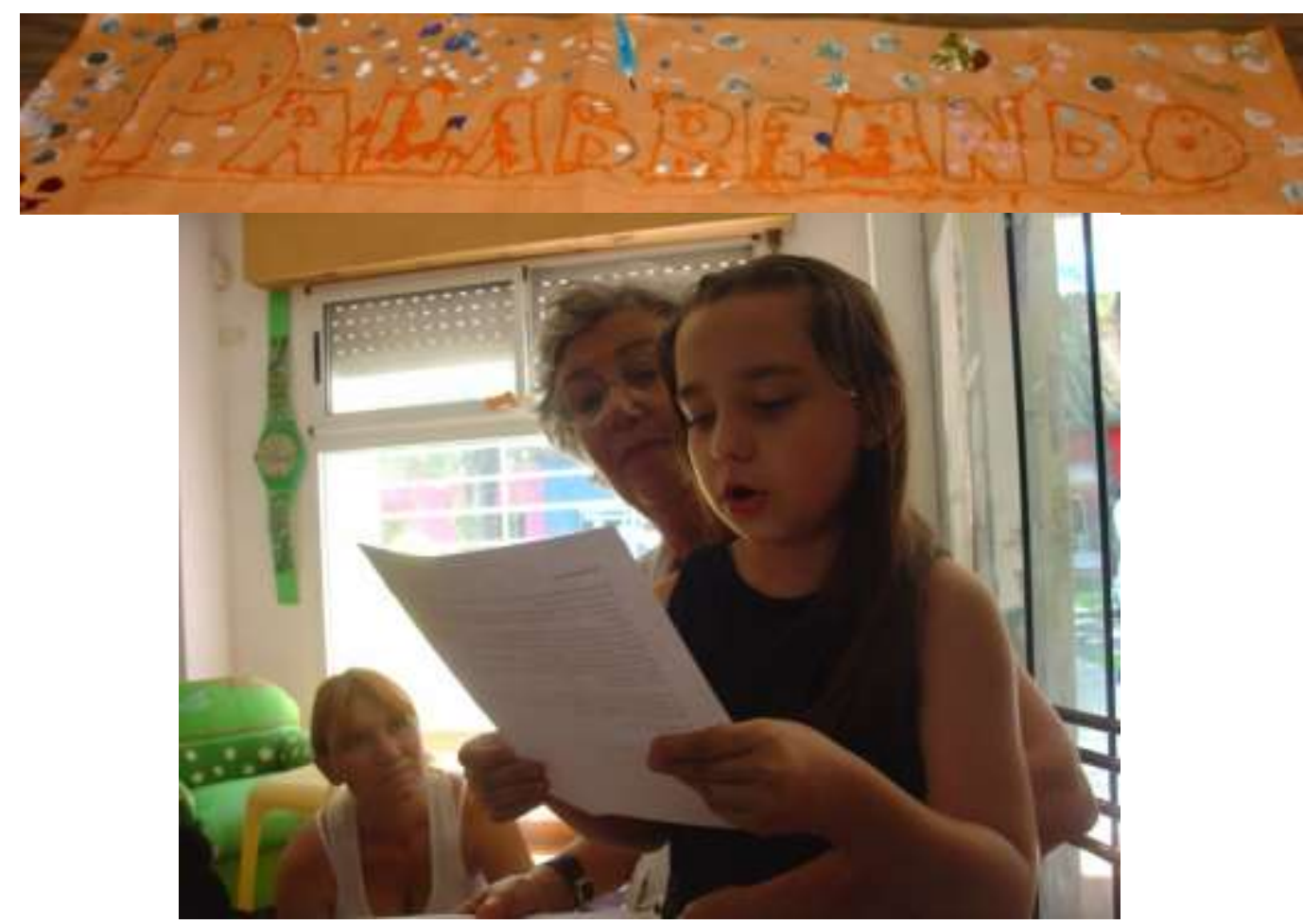

Figura 112 Bibiana Oliva, Amanda Paccotti e Emilia Casadedio lendo seu conto

Ao final da leitura parabenizei a todos pela beleza do trabalho e perguntei se era possível ler outros contos produzidos pelas crianças, se estavam publicados de alguma forma ou disponíveis on line, me disseram que não, mas logo depois, a menina autora, me presenteou com um envelope cheio de histórias, dela e de seus colegas, entre elas a história do peixe punk, que havíamos gostado tanto de ouvir.

\section{El pez Punk}

Un dia el pez Punk se encontró con uma banda de jazz. Entonces le preguntó a uno de los peces:

- Hola, buenas tardes! Cómo es eso de la banda de jazz? preguntó el pez Punk.

- Es uma banda movida - le contestó el outro.

- ah bueno! y está abierta la inscripción? - preguntó.

- Si! Por supuesto!

- Bueno, quisiera inscribirme.

- Tenés que poner tu nombre - le dijo el pez de la banda.

El pez punk empezó a formar parte de la banda de jazz y a componer muchas canciones y a cantarlas en el show.

Un dia en uno de los shows uno de los cantantes se quedó sin voz, la gente esperó tanto que se empezó a ir porque estaba aburrida. Pero el pez punk se dio cuenta de lo que pasaba y empezó a darle ánimos al cantante moviendo sus aletas y cantando para contagiar la gente. De pronto el pez tímido empezó a cantar, las luces de colores se prendieron y los fuegos artificiales iluminaron la noche.

Fue el show más divertido de la banda de jazz y a partir de esse dia se empezaron a llamar "la banda de jazz del pez punk".

(conto inédito de Emilia Casadedio) 
Como ouvir essa história e não lembrar de Monteiro Lobato e sua Emília no reino das águas claras? O pez punk não poderia ser um personagem do Sítio? A imagem da foto não parece a sala do Sítio do Pica-pau Amarelo? Era a vez da Emília argentina abrir sua torneirinha de criatividade...

Desta manhã de sábado surgiu, além do encantamento com o trabalho que acabava de conhecer, uma amizade com Graciela que entre outras coisas me ajudou a entender a história dos desaparecidos da ditadura, o desaparecimento de Marta Diez, sua irmã gêmea, e sua luta por encontrá-la, até hoje em vão.

Dias depois daquele sábado em que nos conhecemos, ela me convidou à sua casa onde eu, Circe, Bibiana e os lindos filhos, comemos as suas saborosíssimas empanadas e conversamos até alta noite. Nas despedidas, às vésperas da minha viagem de volta ao Brasil, tomamos cerveja, comemos um saboroso carlitos, e trocamos muitas figurinhas sobre bibliotecas, livros e leituras.

\section{3 \\ Biblioteca Independiente para el Pensamiento Amplio, Crítico y Poetico}

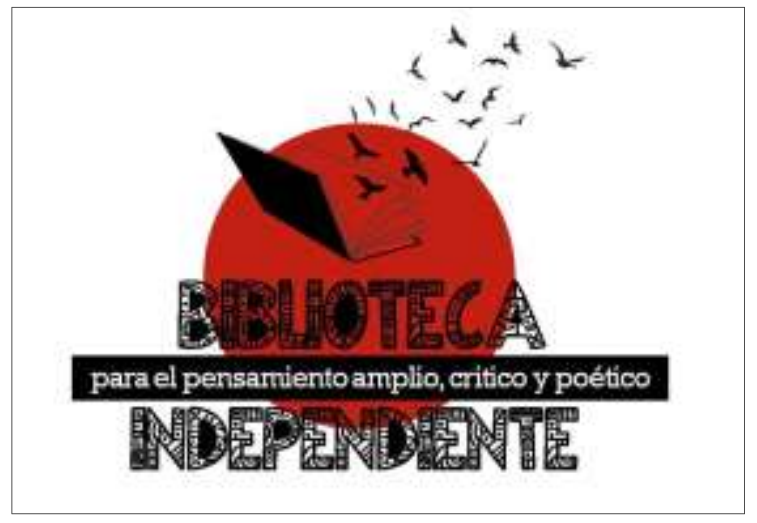

Figura 113: Logotipo Biblioteca Independiente

Num dia lindo, à beira do Rio Paraná, eu conversava sobre os meus interesses como pesquisadora em Rosário, com Solón Neto, brasileiro, estudante de medicina que acbava de conhecer em um almoço de domingo em La Florida, juntamente com mais catorze amigos, todos brasileiros, e ele me disse conhecer Luciana, uma professora muito dedicada e que poderia me ajudar se eu quisesse visitar escolas, falar com professoras. Solón nos apresentou através das redes sociais e iniciamos uma conversa sobre nossos trabalhos. Falando com Luciana 
Andrea Fernandez, que é professora de nível inicial, licenciada em educação e estudou profesorado na cidade de Granadero Baigorria, cidade vizinha a Rosário e a licenciatura na Universidad Nacional de Santiago del Estero, também na Argentina, ela se disponibilizou a me receber na escola em que trabalhava para que eu conhecesse sua forma de lidar com os alunos, mas nossas agendas não combinavam; e sendo as últimas semanas de aula ela estava muito atarefada. Mas naquela semana as aulas terminariam e ela teria mais tempo livre, e me disse que no sábado iria a uma biblioteca recém-criada, que ficava na cidade de Capitan Bermúdez, da qual ela já havia me falado, e que se eu quisesse poderia acompanhá-la. Claro, aceitei o convite. Capitan Bermúdez é uma cidadezinha a meia hora de Rosário e de muito fácil acesso. Fui de ônibus e a aguardei onde havíamos combinado. Cidadezinha pequena, quase ninguém. Quando chegaram, nos apresentamos e fui sendo levada por uma rua calma, rumo à Paróquia Santa Catalina, onde ao lado está uma casinha que pertence à paróquia.
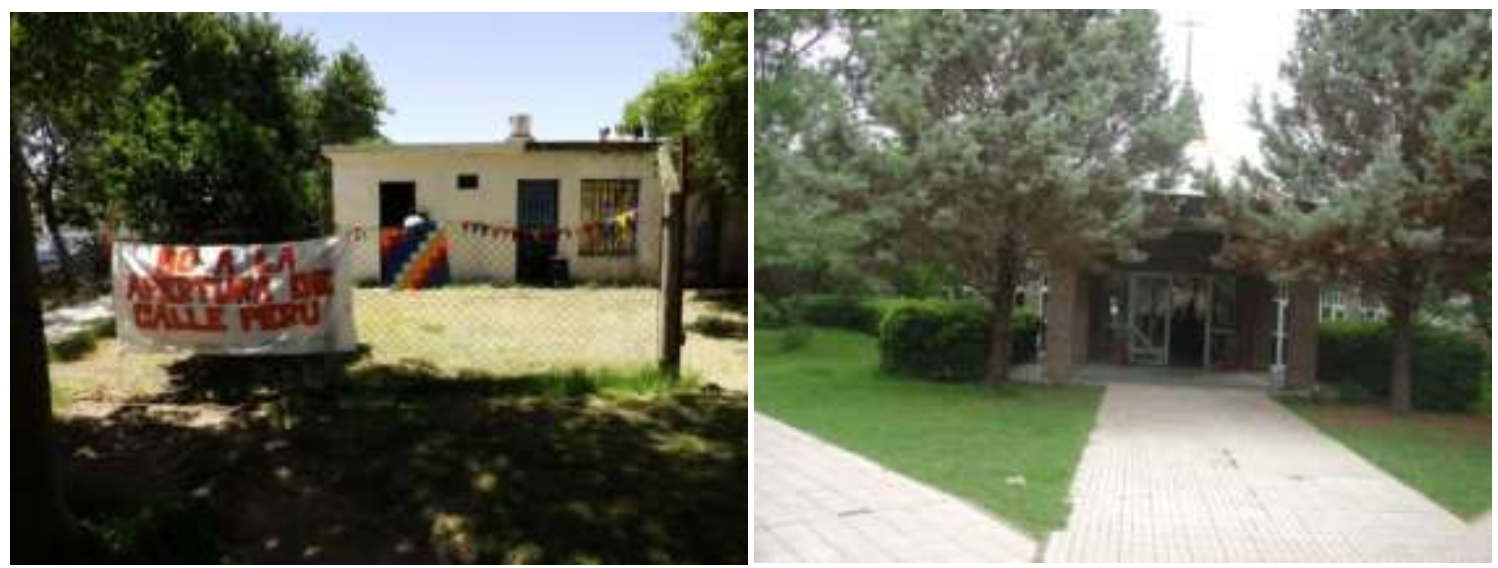

Figura 114: Biblioteca Independiente 1 Figura 115: Paróquia Santa Catalina

Quando chegamos um grupo de pessoas estava fazendo reparos na sala, e logo fui apresentada a todos. Ficaram tão felizes com a minha chegada que me emocionei. Não acreditavam que uma brasileira fora ali com o intuito exclusivo de conhecer a biblioteca. Não demorou a chegar masitas, água saborizada e mais água quente e erva para renovar el mate. Conversamos, partilhamos histórias. Ficaram muito interessados em saber como era o projeto Clubinho de Leitura e Casa de Memória e Cultura, me contaram a luta ambiental que vêm travando contra a utilização de agrotóxicos e a destruição dos espaços verdes, e suas 
experiências com a recém-criada biblioteca. A minha grande surpresa foi saber que a biblioteca fora criada como um ato de resistência à abertura de uma rua entre a igreja e o salão paroquial. Um lindo espaço verde que a ONG Semillas de Futuro defendia e que o pároco cedeu um dos salões da paróquia para que fosse implantada a biblioteca. Para mim o inusitado era que uma biblioteca servisse, literalmente, de arma numa batalha pela preservação ambiental. No a la apertura de la calle Peru, era o que dizia a faixa em frente à casinha, esta era a luta, impedir que a abertura de uma rua destruísse um espaço arborizado, calmo, convidativo para a leitura de um bom livro e compartilhar o mate com amigos. A ideia era tão linda que eu mal podia crer. Aquela atitude me mostrou com veemência a importância que o livro tem para os argentinos.

Também uma peculiaridade era que queriam manter-se independentes, diferente das bibliotecas populares que são projetos dos próprios bairros, mas que formam uma rede que tem apoio oficial através da CONABIP, por isso o nome Biblioteca Independiente para el Pensamiento Amplio, Crítico y Poetico. O espaço que estavam defendendo tinha uma energia muito boa, retrato da tranquilidade de uma cidade pequena.

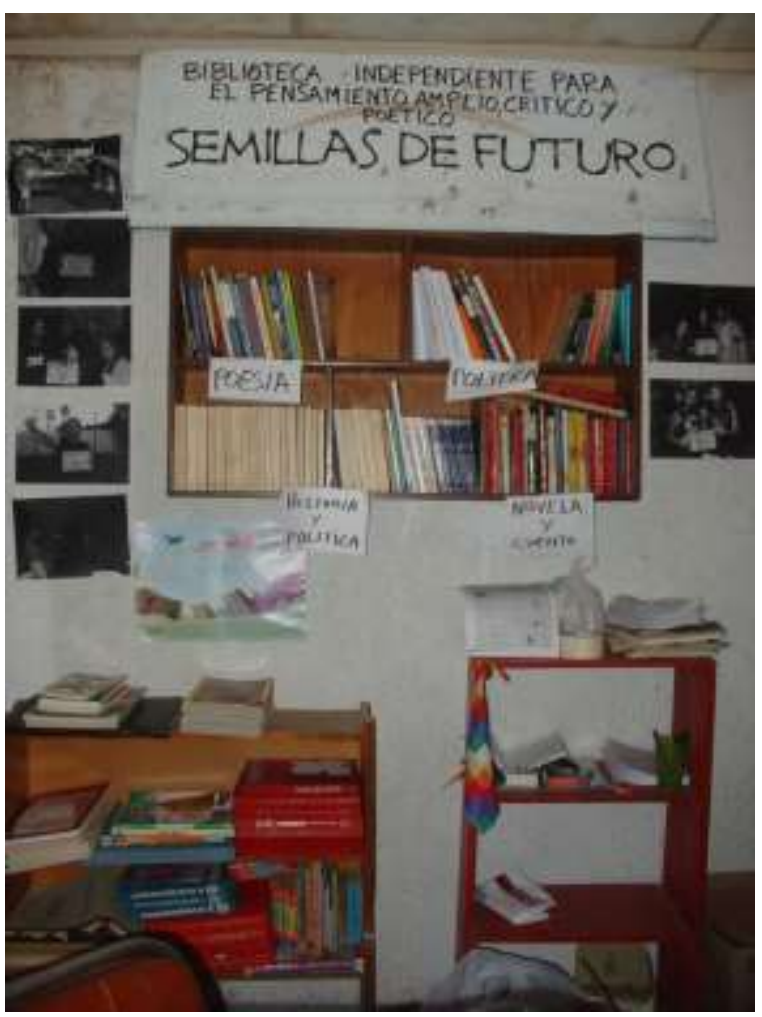

Figura 116: Biblioteca Independiente 2 
Encerrando minha visita, Javier Luis Bernard foi convencido por Luciana a cantar alguma canção do folclore argentino para que eu conhecesse. Entre o canta e não canta, procurando seu violão, fomos para o espaço verde que eles tanto defendem e eu me encontro então com a canção argentina.

Javier: Bueno, a ver uma canción a latinoamérica... Bueno, para la conpañera que vino de Brasil, gracias por venir a visitar la nuestra biblioteca y este espacio que nosotros estamos defendiendo acá para la comunidad, y para los vecinos, que queremos que la gente se integre y que participen, porque para nosotros es importante defender este espacio porque es um pulmón para la ciudad la cual vivimos en un cordón industrial que está... hay mucha contaminación. Entonces queremos preservar este espacio verde en la cual la municipalidad nos quiere abrir una calle, entonces nosotros nos oponemos, porque funciona la biblioteaca hace tres meses. Conjuntamente con la biblioteca atividades culturales: dibujo, peña, peña le decimos a encuentros con los músicos, pintores, todo que tenga que ver con el arte, que se manifieste los vecinos, todo que através del arte quieren acercar, siempre las puertas estan abiertas. Voy hacerte uma cancionzita, a ver se me acuerdo la letra. Se llama dulce madera cantora, lo hice mucho Mercedes Sosa quando anduvo por latinoamerica.

S.8

Guitarra, suena, guitarra,

Que el aire sabe a romero.

Palomas me trae el viento

Bajo el ala del sombrero.

Que huele a sol el mañana,

Guitarrita americana.

Que huele a sol el mañana S.J $^{2}$

Javier lembra Mercedes Sosa, e eu, que gosto muito de suas canções, entendo um pouco mais a alma da grande cantora nascida em Tucumán. E com outra canção celebra a união dos povos latinoamericanos.

S.J

Canta corazón, canta más alto, que tu pena al fin se va marchando, el nuevo milenio ha de encontrarnos, junto corazón, como soñamos.

Más de cinco siglos transitamos sobre nuestra tierra como extraños, si logró la historia separarnos, este canto hoy quiere juntarnos.

Canta, sueña, vuela corazón americano, ya no habrá dolor que nos detenga, somos bajo um sol todos hermanos. א.J

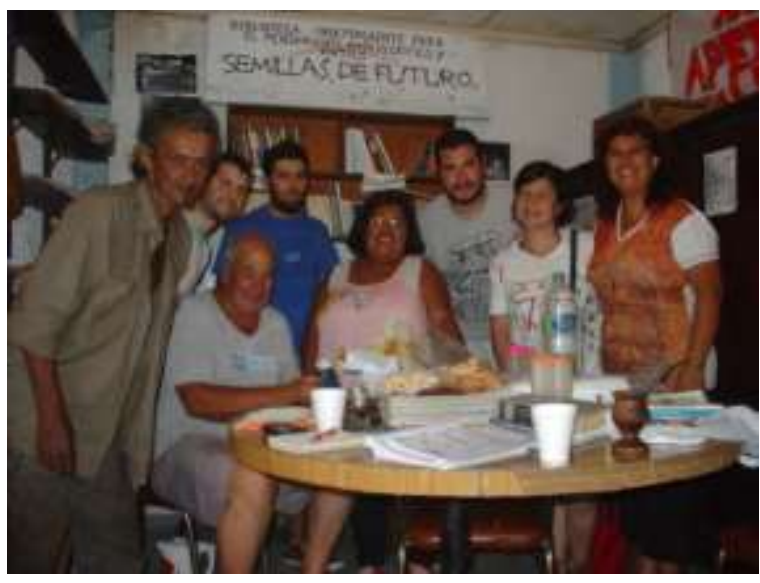

Figura 117: Conhecendo Biblioteca Independiente 
Com a beleza das canções, a simplicidade e seriedade com que o projeto é conduzido, eu entendo que o encontro com o Semillas de Futuro chegava na hora em que eu deveria compreender que por vias distintas muitos grupos estão levantando suas bandeiras, uns com mais veemência, outros no seu dia-a-dia, nas semeaduras onde às vezes há muita terra e pouca fertilidade, para fazer brotar mais humanidade. Com aquele grupo de Capitan Bermúdez eu me emocionava de fato. Javier me leva às lágrimas com sua Vidala para mi sombra.

Javier: Yo voy hacer uma vidalita, voy hacer uma vidalita! me gusta cantar copla, me gusta cantar vidala. Bueno, es ma o meno sensillito, de corazón para que la compañera se lo lleve allá de recuerdo a Brasil... Se llama vidala para mi sombra. És un tema que me gustó mucho la letra, y la vidala, como la vaguala, como las coplitas son temas muy tradicionales, muy milenarios que se cantan en el norte, que se festejan para el carnaval en el norte. Un amigo mio me traje una cajita para hacer vidala, que acá no la traje, pero voy a cantar una canción que saqué hace poquito. Dice asi:
ת. $\delta$
A veces sigo a mi sombra, a veces viene detrás, pobrecita si me muero con quién va a andar.
No es que se vuelque mi vino, lo derramo de intención. Mi sombra bebe y la vida es de los dos.
Achatadita y callada dónde podrás encontrar, una sombra compañera que sufra igual. $\delta$.

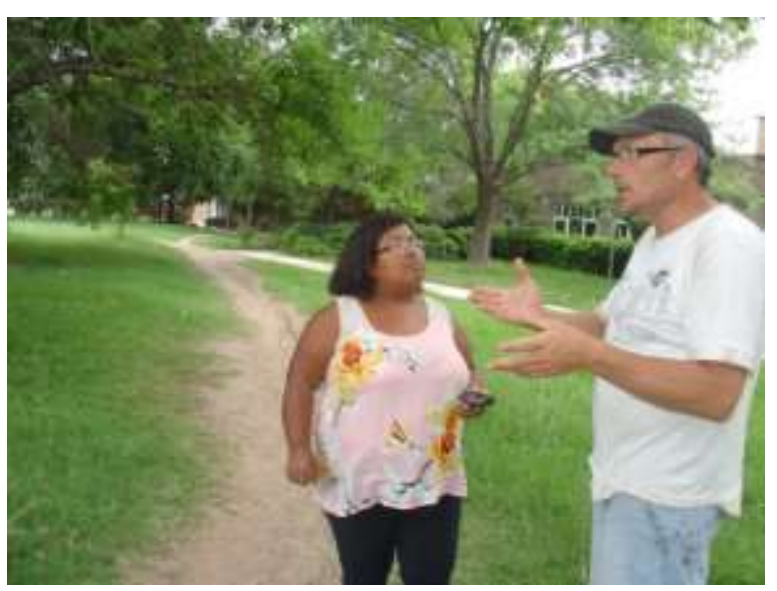

Figura118: Maria de Lourdes e Javier (Foto de Luciana)

Minha emoção vinha da verdade com que cantava. Usando o próprio corpo como instrumento para marcar o ritmo de suas canções, Javier canta com sua alma de pessoa simples e plena de seu ofício de cantar sua terra, sua cultura. Luciana dizia, me vendo com as emoções à flor da pele: es que somos todos hijos de uma misma tierra, de latinoamerica. E era isso. Comungávamos naquele momento de expressões genuínas do povo, a defesa do chão onde estão as suas raízes. Ali, já ao final de minha incursão por aquelas terras que me foram tão acolhedoras, eu recebia uma música para trazer de presente para os que aqui ficaram, companheiros meus de trabalho... 
Javier: Gracias Maria por visitarnos, me emocionó muchísimo cantarte unas canciones... la música hermana "viva latinoamerica" viva Brasil... Argentina... toda Latinoamerica. Fue un encuentro y experiencia maravillosa de compartir la charla, encontrar personas que piensan que otro mundo mejor es posible para todos los que integramos este espacio. Estamos muy felices de seguir luchando y encontrar en el camino gente como vos con un compromiso por los demás. Las puertas de la biblioteca y de semillas de futuro estarán siempre abiertas

Através das redes sociais eu continuo me comunicando com o grupo e vou me informando das mudanças. Duas semanas atrás, no facebook dos "companheiros", como me chamam desde então, considerando-me parte da sua luta, vejo um convite que se fosse mais perto eu teria ido para Capitan Bermudez me juntar a eles.

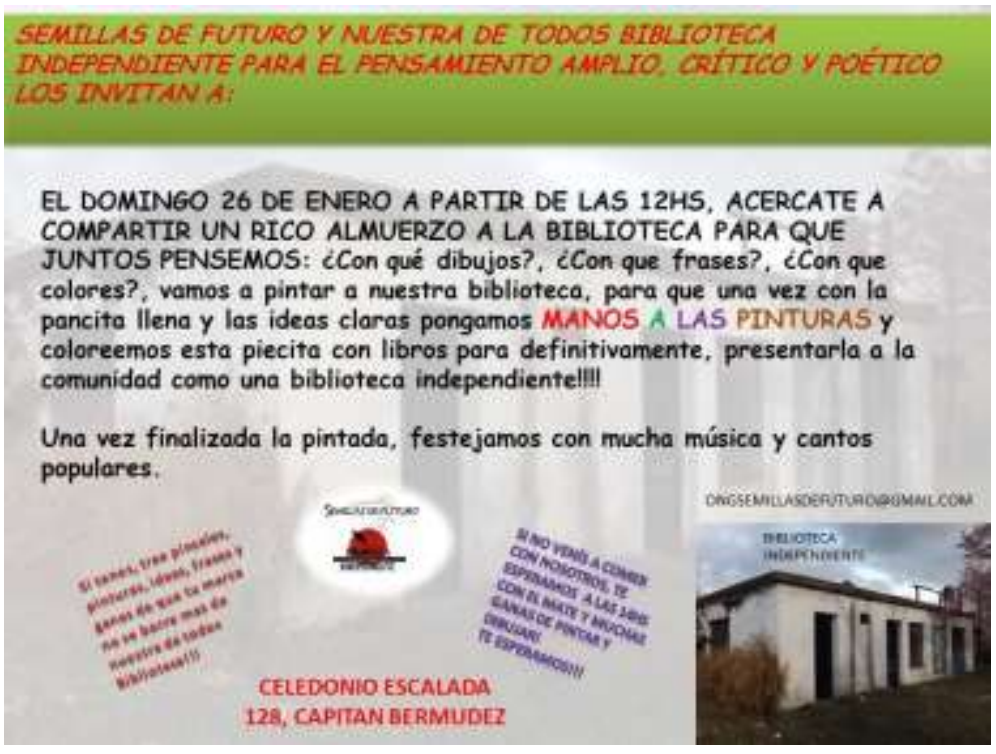

Figura 119: Convite para trabalhos na Biblioteca

E aquela casinha que conheci em momento de reparos, um mês e meio depois ganharia novos livros, novas cores.
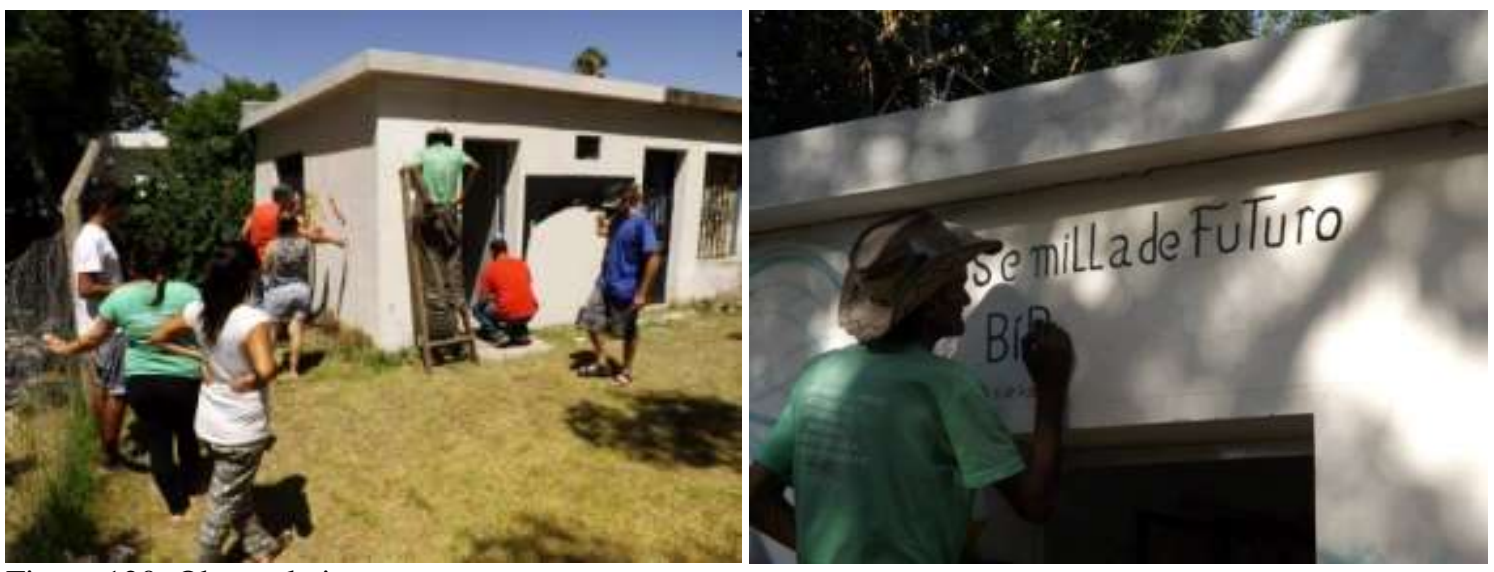

Figura 120: Obra coletiva

Figura 121: Pintando o nome da Biblioteca 

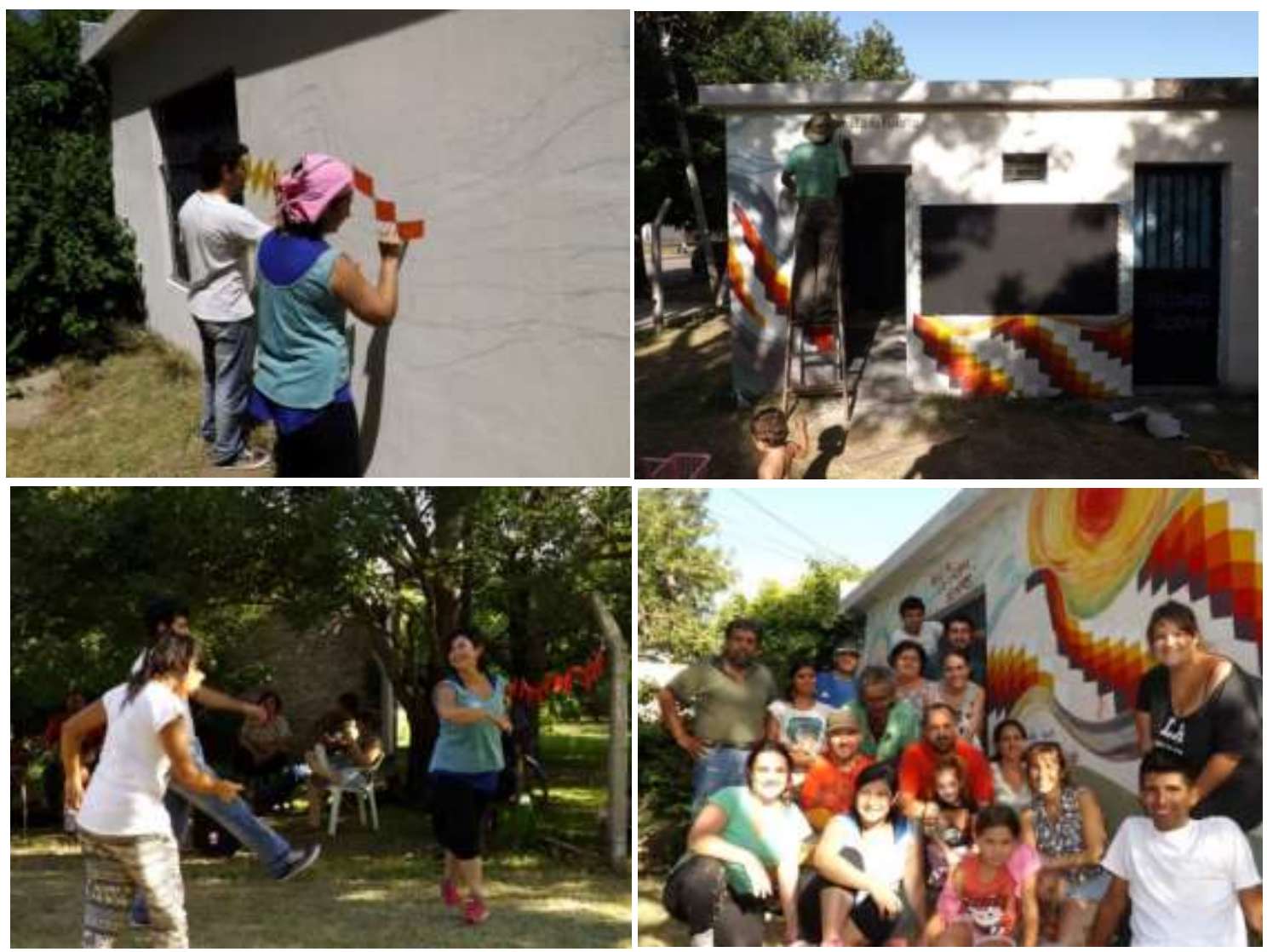

Figura 122: O aprendizado e a alegria do trabalho comunitário 1 Figura 123: O aprendizado e a alegria do trabalho comunitário 2 Figura 124: Dançando para celebrar

Figura 125: Todos somos um

Outros encontros ainda me confirmariam o quanto valera a pena minha vivência em terras argentinas. Os jovens da Bibliomóvil entusiasmados com sua biblioteca ambulante e que são também um Punto de Cultura $^{17}$, me mostraram uma juventude que atua, que quer mudanças. Tive a possibilidade de participar de uma reunião entre representantes de outros Pontos de Cultura das cidades de Córdoba, Entre Rios, Santa Fé e onde estavam presentes também representantes

17 Los objetivos de este programa, implementado por la Secretaría de Cultura de la Presidencia de la Nación, es promover la organización popular a través de la cultura comunitaria. La iniciativa también se propone fortalecer el trabajo de las organizaciones sociales que a través de proyectos culturales promueven la inclusión social, la identidad local y el trabajo colectivo; brindar apoyo económico y técnico para el acompañamiento de proyectos socioculturales; generar una red federal de organizaciones socioculturales de intercambio y cooperación de experiencias de desarrollo comunitario; y generar una herramienta que permita el trabajo mancomunado entre las organizaciones de la sociedad civil que llevan a cabo proyectos socioculturales y el Estado Nacional. (Fonte: http://www.cultura.gob.ar/acciones/puntos-de-cultura/ ) 
de bibliotecas populares vizinhas ao Centro para una Cultura Alternativa y Popular, onde um grupo de jovens leva adiante projetos culturais para o bairro.

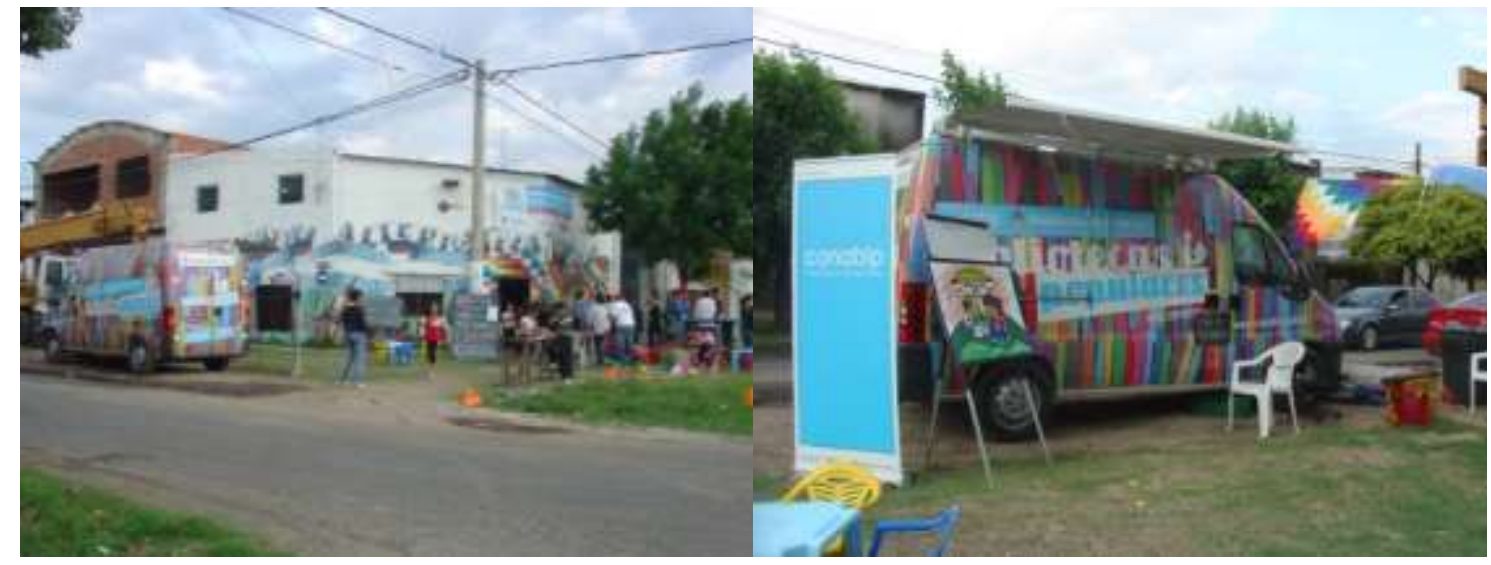

Figura 126: Centro para una Cultura Alternativa y Popular Figura 127: Bibliomóvil

\section{5}

\section{Biblioteca Municipal y Popular Jose Hernandes}

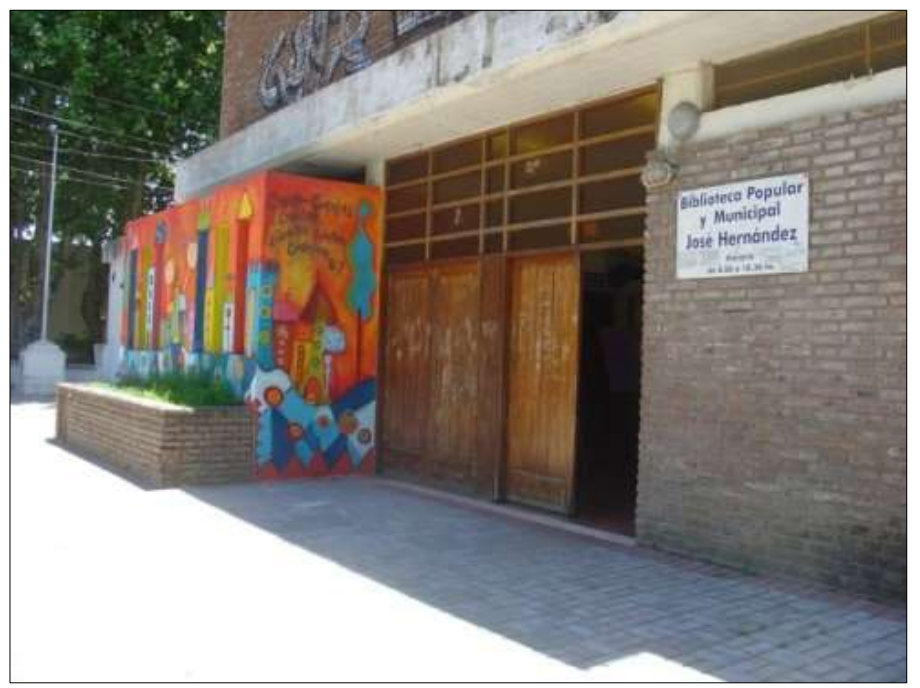

Figura 128: Biblioteca Municipal Popular y Popular Jose Hernandez

$\mathrm{Na}$ cidade de Granadero Baigorria, outro lugar onde pude intercambiar experiências, e onde tive a oportunidade de ler um conto do meu livro traduzindo de improviso durante a oficina de literatura coordenada por Laura Borletto. E visitei também a Casa de Cultura que funciona na antiga estação de trem de Granadero Baigorria. 


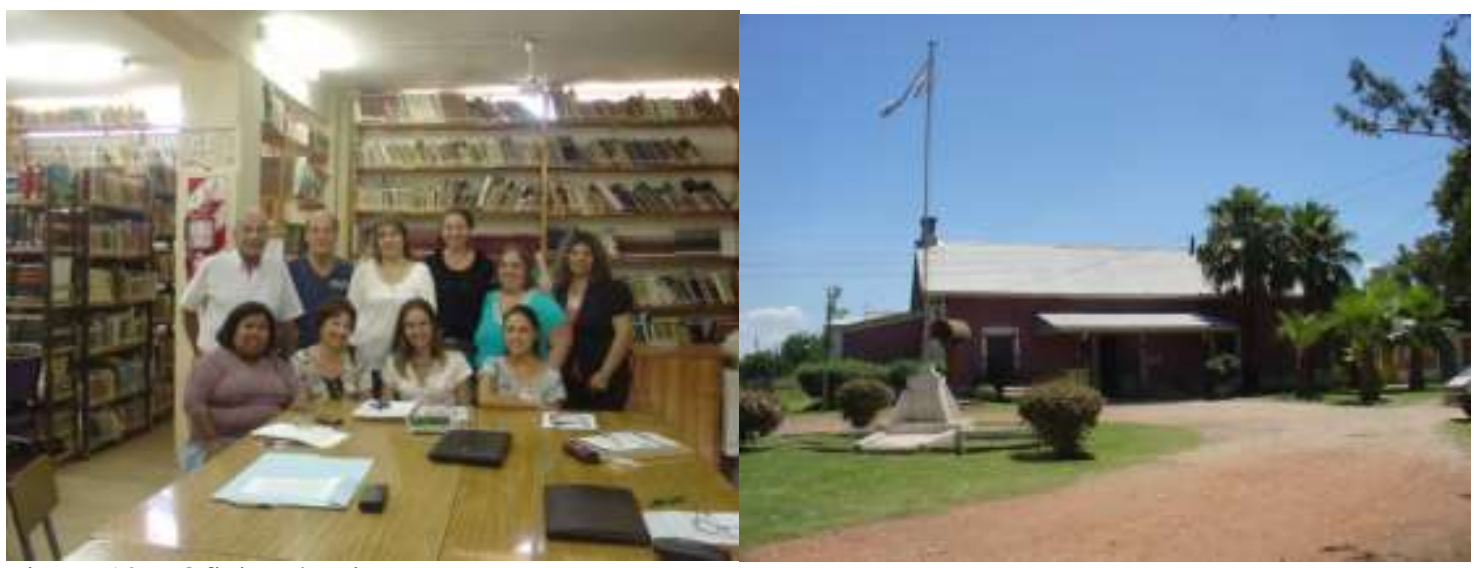

Figura 129: Oficina de Literatura

Figura 130: Casa de Cultura Granadero Baigorria

Na semana seguinte Mariela Aspiazu, uma das frequentadoras da oficina, que nos recebeu em sua casa para um chá, me levaria à Biblioteca Municipal Mariano Moreno, que funcionava numa antiga estação de trem e que estava em vias de ser trasladada a outro prédio, na cidade de Fray Luis Beltran. E ao Museu Historico Regional, na cidade de San Lorenzo, onde eu teria um encontro feliz com nosso Paulo Freire, através de suas frases que compunham um quadro-negro na seção dedicada às escolas. Era bom me deparar com um brasileiro que respeito e que tanto fez pela educação no meu país sendo reverenciado. De certa forma, me senti pertencente àquele museu pelas palavras do educador que tanto fez para que a educação chegasse de fato a todos os cantos do país, que pensou um jeito próprio de educar. Uma reverência merecida.

As frases eram puro ensinamento, contundentes.

Frases de Paulo Freyre (que compõem a imagem a seguir)

Hoy está nublado.

Educar es escuchar.

Nadie es, se se prohiben que otros sean.

Decir la palabra verdadera es formar el mundo.

Enseñar exige saber escuchar. 


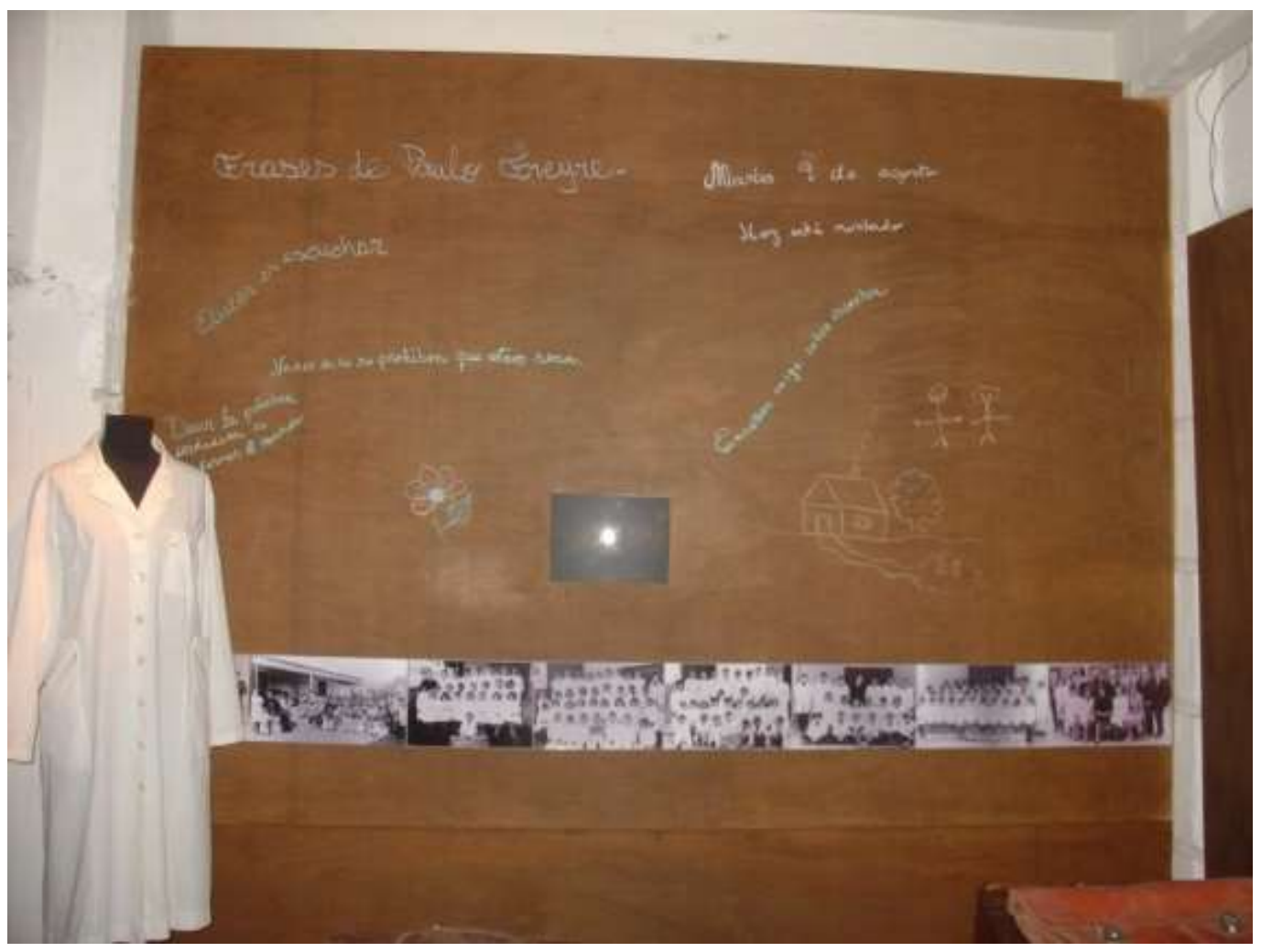

Figura 131: quadro-negro com frases de Paulo Freire

Todos esses encontros nos enriqueceram a todos nos permitindo intercambiar experiências, pensar nossos fazeres com a cultura de nossos lugares, nossa história e nossos costumes. Se posso sintetizar meus aprendizados nesses três meses vivendo em Rosário, digo que mais profundamente eu sei que o livro pode ser um promotor de transformações. Que uma biblioteca pode ser um ponto de referência cultural de primeira necessidade de uma comunidade, de um bairro, de uma cidade, seja ela grande ou pequena. 


\section{6 \\ Reflexões e caminhos}

A raça humana é

Uma semana

Do trabalho de Deus

A raça humana é o cristal de lágrima

Da lavra da solidão

Da mina, cujo mapa

Traz na palma da mão

(Gilberto Gil)

Denise Gusmão usou, durante sua pesquisa, a fotografia como uma das suas metodologias de pesquisa. No início as pessoas se esquivavam da câmera, mas depois tornou-se habitual. A certa altura todos haviam entendido e respeitavam o olhar de Denise e a avidez das lentes de suas câmeras fotográficas. O tempo nos ensinava.

As fotografias que fazíamos eram sempre reveladas e depois levadas de volta ao Córrego dos Januários para que as pessoas fotografadas se vissem e conversassem sobre elas. A fotografia tornou-se uma facilitadora das narrativas que Denise buscava. Outras vezes os moradores eram os fotógrafos e depois das fotos reveladas analisavam o próprio trabalho, falava do que sua fotografia queria contar. Foram muitas fotografias e muitos fotógrafos, e a pesquisadora precisava de autorização das pessoas para utilização das imagens na sua dissertação de mestrado, na tese doutorado e nas apresentações públicas de seu trabalho, e procurar as pessoas fotografadas, filmadas e recolher as assinaturas era uma tarefa que cabia a mim.

Logo no início dos trabalhos junto com Denise fui à casa de Marcelo e Elizete, pais de Fabiane, Dayane e Rafaela para que eles autorizassem a utilização das imagens das filhas menores de idade. Ele estava na roça e Elisete me disse que precisava consultar o marido. Esperei que ele descesse para o almoço e expliquei a natureza do documento que eu precisava e ele me disse mais ou menos assim: olha Toquinha, eu não entendo nada dessas coisas de faculdade e de internet, mas se é você que tá dizendo, que é pessoa aqui do lugar, séria e de confiança, eu assino. Este foi um momento de validação da minha ação. Eu estava autorizada a falar e agir em nome da confiança. A minha responsabilidade cresceu 
imensamente. E Marcelo, no decorrer do trabalho, foi se envolvendo e se reconhecendo. A seriedade do vínhamos fazendo e a valorização do que ele representava como pessoa na comunidade fez crescer uma relação de confiança dele em mim e em Denise.

Reproduzo abaixo um trecho de minha conversa com Marcelo que faz parte da dissertação de mestrado Por uma Estética da Delicadeza: ressignificando contos e imagens nas roças de Minas, de Denise Gusmão. A nossa conversa é sobre a fotografia dele também reproduzida abaixo.

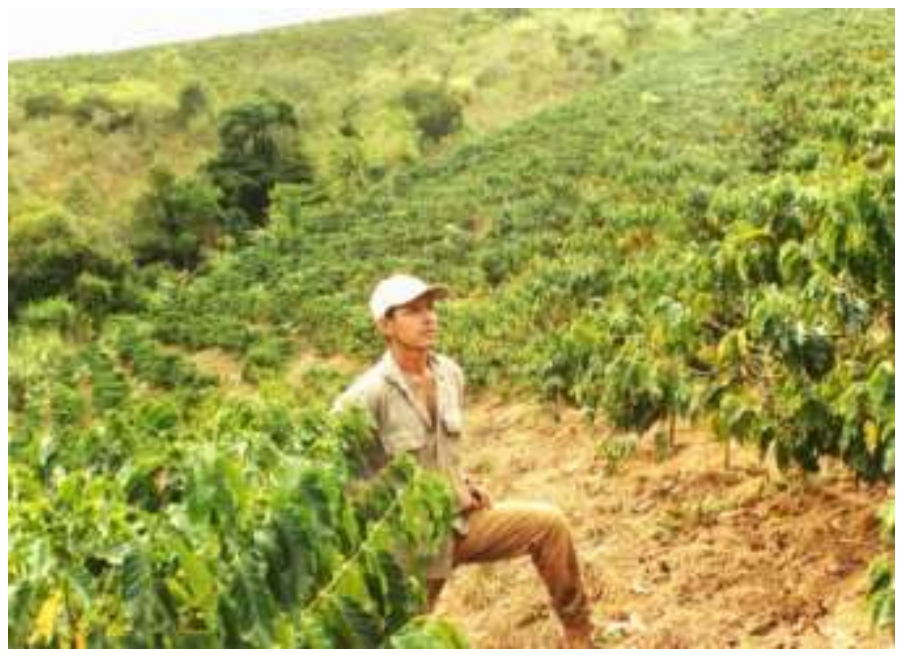

Figura 132: Marcelo (Foto de Denise Gusmão)

Marcelo: Aqui eu vejo assim, a primeira coisa é sentimento de lembrança do pai, né? E do lugar, né, olhando o serviço onde que ele criou a gente, né, criou os filhos dele aí. Então eu tô olhando assim, pelo tipo do lugar que a gente tava olhando assim pra cima, me dá um tipo de muito pensamento na hora, né? De muito sentimento. E eu fico pensando assim, a mesma dificuldade que ele teve pra criar a gente e que a gente vai ter, mas com as graça de Deus a gente vai conseguir também criar a família da gente também, né? E dá uma esperança, um sentido de uma esperança, que todo mundo tem suas dificuldades, muita gente tem, mas a gente vence também.

Toquinha: Você vê que na foto você tá pensando isso, você sente que na foto você tá pensando?

Marcelo: É, é, eu sinto, na hora que vocês me mostraram esse retrato lá e na hora lá no dia veio foi essas coisas na minha cabeça. O pensamento. E isso aqui, esse retrato eu vou guardar ele. Daqui uns anos a gente ter de recordação.

Toquinha: Eu achei lindo também a foto que você está com as suas filhas, que elas estão colhendo café junto com você, a sua alegria. (nesse momento ele pega a foto em que está com as filhas). 


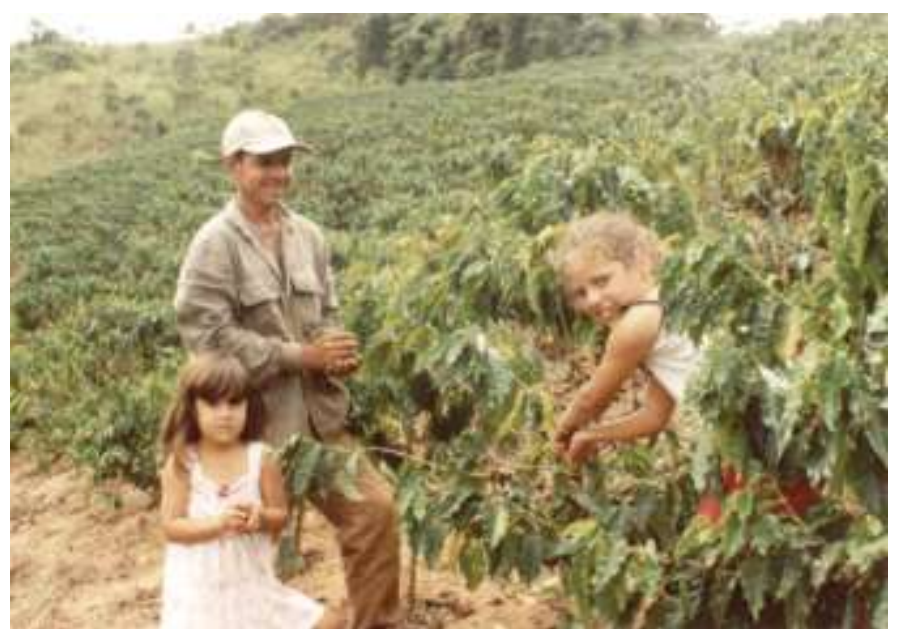

Figura 133: Marcelo, Rafaela e Dayane (Foto de Denise Gusmão)

Marcelo: É. Aqui você tá vendo uma coisa que é maravilhoso de bom, como dizo outro, né? Que é a família da gente, né? Eu não sei falar, não, mas eu, me vendo eu ali assim passa muita coisa na cabeça da gente. É um sentimento, dá um modo de parecer que a gente não pode perder a esperança não, né?

Toquinha: Aí uma coisa simples, aquele dia a gente foi ali na roça assim sem uma preocupação assim. Queria fotografar vocês, né, registrar vocês trabalhando, mas de repente vem uma resposta dessa e assim a gente fica emocionado, porque a gente também lembra.

Marcelo: Eu tenho muito sentimento. Eu não sei, eu não gosto, tem uma porção de retrato que eu não gosto não, sabe. Esse daqui mesmo é um dos que eu achei melhor até hoje, de retrato que eu tirei até hoje. Eu tô, ocê vê que eu tô de chinelo no pé, né, com a roupa de trabalhar, né? Eu tô fazendo o que eu sei fazer, na minha profissão, né?

Toquinha: Essa foto, eu adoro essa foto. Eu olho ela assim eu sinto uma paz. Parece que você tá assim tão feliz. É o meu sentimento de te ver assim.

Marcelo: E antes de imaginar, eu olhando pra ela aqui assim e sentindo que, dentro de mim aqui, a gente é um ser humano, né, e olhando assim pra ela assim, antes d'eu imaginar outras coisas também, uma primeira coisa que vem na memória da gente, no pensamento da gente, primeiro assim meio caladinho assim, meio escondidinho assim, um pensamento é em Deus também, a primeira coisa, né?

Assim, o que eu sinto, sabe, o modo que eu fiquei pra cima aqui, eu fico olhando, eu fico, n'eu ver aqui assim eu sinto: eu lá e eu aqui assim eu sinto uma ligação com Deus nessa hora.

Toquinha: Aí você vê a importância do registro, porque se não tivesse tirado essa foto talvez você não tivesse feito essa reflexão, né?

Marcelo: Não, é, passava. Porque eu na hora lá, no dia que eu vi, peguei e tava refletindo assim, pensando assim também, eu até falei, me parece, aonde há mais de 20 anos, né, que o papai plantou essa que tá aqui (plantação de café) em cima aqui e essa que eu tô aqui agora foi o papai que plantou. Então eu fiquei pensando assim: há mais de 20 anos eu tô trabalhando onde ele trabalhou, fazendo o que ele fazia, e sempre tendo a recordação dele, né? Uma pessoa que deu um bom exemplo pra gente. Os pais, os antigos daqui do nosso lugar, né, todos deram uma boa educação pra gente, um exemplo de vida pra gente. Agora, o sentimento a gente tem, boba. Eu sou um cara meio sério mesmo assim, meio acanhado, mas eu tenho muita coisa boa, eu tô começando a descobrir agora. (GUSMÃO, 2004, p.141-143) 
Ao olhar a própria fotografia Marcelo abre o coração. É solidário comigo ao externar seus sentimentos. Refletindo sobre si mesmo ele, sendo um lavrador, homem simples e de poucas palavras, como ele mesmo diz, se reconhece um ser humano, um perpetuador da memória do seu pai e entra em sintonia com Deus. No encontro comigo e com Denise aquele pai de família encontra palavras para dizer de sua esperança em vencer as dificuldades, em criar decentemente sua família. Paul Ricoeur fala desse processo de reconhecimento de si que precisa da ajuda de outrem.

"Longo é o caminho para o homem que "age e sofre" até o reconhecimento daquilo que ele é em verdade, um homem "capaz" de certas realizações. Esse reconhecimento de si ainda requer uma etapa, a ajuda de outrem, quando falta esse reconhecimento mútuo, plenamente recíproco, que fará de cada um dos parceiros um ser reconhecido (...). (RICOEUR, 2006, p. 85)

E é na interação que eu e Marcelo nos encontramos e nos reconhecemos o suficiente para abrirmos nosso coração. Quando fala de sua sensibilidade é porque vê sensibilidade em mim. Somos cúmplices no processo de descoberta de nossas capacidades.

Com o escritor uruguaio Eduardo Galeano reconheço ainda o caráter político da minha ação de leitora e de autora.

Escrevemos a partir de uma tentativa de encontro - para que o leitor comungue com as palavras que nos vieram dele, e que a ele regressam como impulso e profecia. (...) Sustentar que a Literatura, por si mesma, vá transformar a realidade, seria um ato de loucura ou de soberbia. Entretanto, parece-me igualmente incorreto negar que ela possa ajudar em algo. (GALEANO, 1978, p. 21)

Eu descobrira os textos de Eduardo Galeano na estante da casa em que eu trabalhava como babá e depois assumindo todos os serviços da casa. Eu me reconhecia em muita coisa que ele escrevia. E um dos textos que me ajudaram a compreender a minha ação se chama "Em defesa da palavra", do livro Vozes e crônicas: "Che" e outras histórias (Ed. Vozes). Ele fala muito do poder da palavra e da ação de quem escreve em tempos de repressão. Mas muito do que ele escreve me serve, me diz.

É bem possível que uma literatura no processo de crise e de mudança - metida a fundo no risco e na aventura de seu tempo - ajude a criar os símbolos da realidade nova; se não faltar talento e coragem, essa literatura ilumine os contornos do novo caminho.(...) Não é inútil cantar a dor e a beleza de ter nascido na América. (GALEANO, 1978, p.20) 


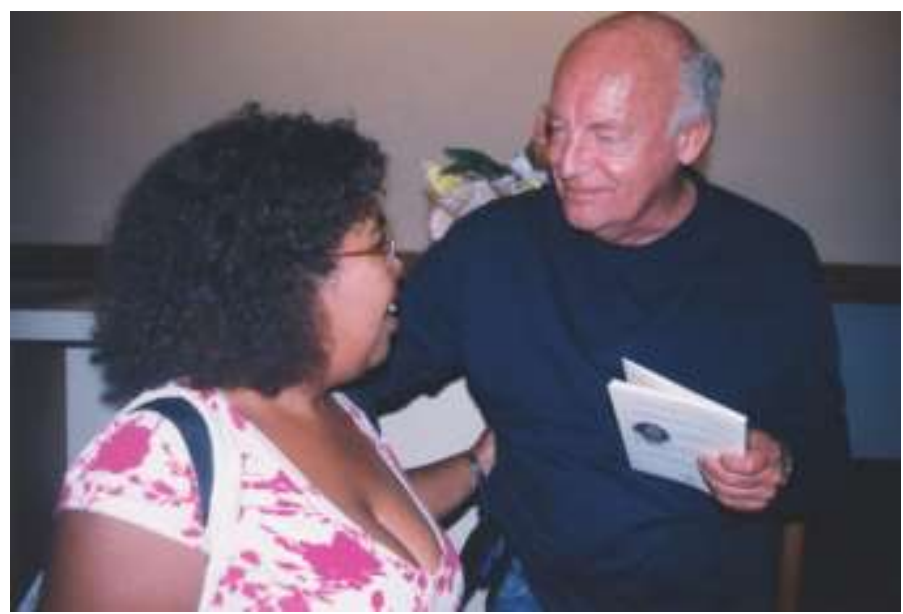

Figura 134: Toquinha e Galeano no Auditório do RDC-PUC-Rio (Foto de Denise Gusmão)

Tive a alegria de conhecer Galeano pessoalmente. Ele autografou o livro e depois, muito timidamente, perguntei se ele aceitava meu livro de presente, ele esperou que eu fosse até onde estava minha bolsa buscá-lo e o entregasse, sempre muito atencioso. Falei da minha admiração pelos seus textos, principalmente do "Em defesa da palavra"; ele ficou surpreso e pareceu gostar. Guardo o registro fotográfico dessa noite como um presente da vida e de Denise, a fotógrafa. E, tomando de empréstimo suas palavras para dizer de meus pensamentos e sentimentos, sinto que ao escrever é possível oferecer o testemunho de nosso tempo e de nossa gente, para agora e para depois. Assim a minha escrita vai sendo imaginação e realidade. Minha literatura vai transitando entre o testemunho e o sonho. E torna-se também esperança.

Junto com a descoberta da literatura eu identificava preconceito, humilhação, esquecimento. Eu ia lendo, escrevendo e pensando nas injustiças, me indignando com a falta de quase tudo. A literatura me ensinava essas coisas além da beleza de um verso bem escrito, a delicadeza de algumas histórias, a dureza de outras. Os livros me davam a conhecer muitos mundos. E eu percebi que a falta de livros me atrasara demais a vida. E descobria por um lado um mundo lindo das artes como a música, a literatura, o teatro, o cinema, artes plásticas; por outro as mazelas. Naquela casa de língua espanhola, aprendi também a preparar uma mesa bem posta, fazer bolo confeitado e doce de aniversário, fazer sushi e a falar a língua deles.

Lembro de quando Fernando Henrique Cardoso ganhou as eleições para Presidente da República, em uma entrevista para uma rede de televisão, ele disse, 
respondendo a não sei que pergunta, que o livro "As vinhas da ira", de John Steinbeck, o tinha marcado muito, e que era uma inspiração. Corri até a estante e encontrei o livro citado. Li. Depois de ler a última página fechei o livro muito decepcionada/preocupada, pois o texto realmente era maravilhoso, mas tinha um fim nada inspirador, a meu ver. Contava a história de uma família americana que perdia suas terras para o sistema bancário e rumava para a Califórnia em busca de dias melhores trabalhando nas plantações de uva. A família amarga dias muito difíceis, de falta das condições básicas de sobrevivência. E o romance termina com a angústia de uma jovem mãe que, morto o filho pela precariedade das condições, sob forte tempestade, fecha a história amamentando o ancião da família, única fonte de alimento para aquele homem muito debilitado, à beira da morte. Confesso que fechei o livro sem entender muito porque citá-lo num momento tão decisivo, ele devia de fato tê-lo como referência, pensei. Não o achei nada inspirador para quem acaba de assumir a presidência de um país com todos os problemas como o nosso.

Com a literatura eu pude me dar conta de que eu havia tido na minha vida a riqueza de um contador de histórias. Que eu tinha transitado de uma cultura totalmente oralizada para a cultura da leitura e da escrita, e me encantava com ambas. E agora tinha acesso ao jornal diário, prestava atenção aos noticiários. Meus sentidos aguçaram.

$\mathrm{Na}$ lida mais intensa com a palavra eu me portava como Bartolomeu Campos Queirós, escritor mineiro por quem me afeiçoei, e cujos textos me comovem por, entre outros aspectos, compartilharmos de uma cultura com as mesmas características. Escrevia minhas memórias, minhas lembranças de infância e de histórias que me contavam.

Se a literatura é uma extensão do autor, a mim ela surge pela falta. Meu desejo é talvez contar para os mais jovens aquilo que gostaria que fosse narrado a mim. Mas $\mathrm{o}$ ato de escrever dá sentido ao meu cotidiano. À medida que escrevo e me surpreendo com aquilo que eu não sabia que sabia eu me torno mais amigo meu. Não sei se crio para estar com o outro ou por saudade da minha infância, e, quem sabe, pela alegria de ter vencido aquele tempo.

(...) Criar, para mim, é a alternativa derradeira para abrandar o peso do não-sabido. E eu tenho um desejo imenso de alterar a comunidade em que vivo. (QUEIRÓS. 2002, p. 158) 
E então eu fui me reconhecendo como a pessoa que tem um papel a cumprir Eu precisava falar e escrever a história da minha gente, da comunidade em que vivi até os meus dezoito anos. Eu ganhei um papel social que eu não reivindiquei, que me foi sendo posto nas mãos e eu me apaixonando por desempenhá-lo. O mundo da leitura me levou ao mundo da consciência, pois, como diz Eliana Yunes, ler é um ato de primeira instância no esboço da consciência de si mesmo e do outro e de sua inscrição no mundo se dá como uma escrita da vida. (2009, p. $35)$.

A leitura foi me permitindo aclarar os contornos da minha realidade e derrubar barreiras culturais, sociais e econômicas. E me dei conta de que vivia na fronteira entre alguns mundos, e isso me confundia um pouco. Eu era professora que trabalhava como empregada doméstica para me sustentar, lia literatura e escrevia contos sobre a tábua de passar roupas, minha mesa improvisada. Eu ia dando meu jeito. Frequentava bons restaurantes a convite de amigos, tecia laços de amizade com artistas da Zona Sul do Rio, me apresentava como contadora de histórias em alguns teatros e espaços culturais e voltava para meu quarto, pois tudo isso acontecia enquanto eu trabalhava ainda como empregada doméstica. Alguns não entendiam essa minha relação com a arte, e era complicado explicar, pois o que muitos não sabiam era que justamente por trabalhar na Zona Sul, eu estava mais próxima de pessoas que lidavam muito de perto com o universo da cultura, das artes, e me abriam as portas, facilitavam o meu contato com o mundo das letras. Enquanto eu me equilibrava nesse viver entre dois mundos, via a cultura da minha terra se perdendo porque uma nova cultura estava sendo implantada no curso natural do progresso, se sobrepondo à história local descaracterizando toda uma memória como que soterrando a própria história, não num intercâmbio de conhecimentos, numa somatória de valores, mas de substituição inconsequente. Eram reflexos do modo acelerado como a tecnologia nos acercou da grande cidade, dos meios de comunicação e suas muitas implicações. Eu só tinha uma grande inquietação, um desejo de resguardar a história que rapidamente perdia suas referências. Aquilo chegava a me doer. A consciência que eu vinha adquirindo me pedia ação. Mais e mais eu ia me dando conta de que ter consciência e manter os braços cruzados era incoerente, de pouco proveito. Ler tanto, aprender tanto, pensar tanto e continuar sem ação era de pouca 
valia. Eu precisava, então, agir. Algumas leituras foram me marcando, me fazendo reconhecer em mim um sujeito político, que não quer dissociar a teoria da prática. A poesia me falava da necessidade de mudar os olhares sobre esse mundo em que vivemos, e me instigava a pensar na construção de pontes entre mundos distintos. E um dos poemas de Galeano me marcou profundamente.

\author{
Para que sirve la utopia? \\ La utopia está en el horizonte - dice Fernando Birri - \\ Me acerco diez pasos, ella se aleja dos pasos. \\ Camino diez pasos y el horizonte se corre diez pasos más allá. \\ Por mucho que jo camine, nunca la alcanzaré. \\ Para que sirve la utopia? \\ Para eso sirve: para caminar. \\ (Eduardo Galeano)
}

E eu entendia que a a raiz das diferenças, da pobreza, do preconceito, essas pragas da humanidade estava na desvalorização das culturas que não a dos grandes centros. E me fazia pensar que se o que me constituía era de pouco valor para o mundo letrado, então eu, pessoa, também não tinha lá muito valor. Os homens se dividiam porque uns se achavam mais homens do que outros. Na conversa com Zildinha, a contadora de histórias, ela fala da mudança de comportamento, desses homens que se acham mais homens do que outros homens. Nomeia a diferença de classes, o preconceito na sua convicção de que sermos considerados iguais como seres humanos traz felicidade.

Zilda: Os vizinho antigamente era longe um do outro... num era amontoado assim não. Hoje em dia, pergunta eu se eu vô nesses vizinho assim... eu vou na reza, se precisá de fazer uma coisa ali eu vou, mas... a Dete aqui eu converso muito com ela porque ela conversa de lá, eu converso de cá, mas num é assim ficar indo lá, vem cá. e a televisão tá chamano muito a atenção. Aí janta, ali mesmo vê um pouquinho, ali mesmo já dorme, ali mesmo já é noutro dia. Ô Toquinha, cê chegava na minha casa e num falava que eu já tinha jantado e arrumado cozinha. Hoje cê pode chegar na minha casa aqui $6,7 \mathrm{~h}$ da noite e a gente num jantou não. $\mathrm{E}$ as vasilha fica é pro outro dia mesmo. (risos) Mas era gostoso, né?

Toquinha: era bom, né?

Zilda: Mas era menos de violência. Hoje em dia qualquer coisinha as pessoa tá se trancano pro outro, né? Fechano a cara pro outro... e no nosso tempo não, no nosso tempo num tinha esse negócio de oiá pruma pessoa e tá de cara feia pra gente, porque era aquele negócio assim, todo mundo era aquilo ali.

Toquinha: E porque cê acha que ficou assim?

Zilda: Ah, eu acho que é ignorância demais. Porque eu acho que cada um quer ser maior do que o outro, né?

Toquinha: Será? 
Zilda: Eu acho, cê num acha não. No nosso tempo, Toquinha, todo mundo era igual... ninguém era rico, ninguém era pobre. Era tudo igual. Hoje em dia um quer ser mais do que o outro. Ocê passa perto de um e fala, passa perto de outro e já num fala. Por qualquer coisinha as pessoas já guarda muita mágoa. Mas isso aí até o padre fala, eu acho, que isso aí mais é ignorância. $\mathrm{E}$ as pessoas, um se sente mais do que o outro.

Zilda tem opinião definida, e nesse mundo de muitas diferenças, de muitas barreiras, havia muito a ser feito. E eu vi que eu, mulher, pobre, negra, sem atributos de beleza que me ajudassem, tinha muitos nós a desfazer. A cultura que eu adquiria com a leitura me dava direito a utopias e, nas palavras de Galeano, a fazer delas impulso para caminhar. Eu conquistava, como a moça tecelã, no conto de Marina Colasanti, o poder de tecer e destecer minha própria história. E especialmente o texto de Galeano "Em defesa da palavra", já mencionado, me fez pensar com mais propósito no compromisso social que eu ia assumindo internamente, mas mantinha adormecido.

As pessoas escrevem a partir de uma necessidade de comunicação e de comunhão com os outros, para denunciar aquilo que machuca e compartilhar o que traz alegria. As pessoas escrevem contra sua própria solidão e a solidão dos demais porque supõe que a literatura transmite conhecimentos, age sobre a linguagem e a conduta de quem a recebe, e nos ajuda a nos conhecermos melhor, para nos salvarmos juntos. (GALEANO, 1978, p. 14)

No contato com textos dessa natureza, que reivindicam um papel social para a literatura, que estão pensando nos caminhos pelos quais passamos, e nos que construímos para que outros passem, está a ideia de que ao se escrever, é possível oferecer o testemunho de nosso tempo e de nossa gente, para agora e para depois (...) "Estamos aqui, aqui estivemos; somos assim, assim fomos. (p. 22). E penso na responsabilidade de quem lida com a palavra.

\section{1}

\section{Direito de sonhar e de realizar}

Há um vídeo em que Galeano, em visita à Espanha, lê o poema inspirado numa definição de utopia expressa pelo diretor de cinema argentino, Fernando Birri. O apresentador do vídeo introduz a fala de escritor uruguaio com uma frase dita por jovens concentrados em manifestações nas praças da Catalunha, Espanha: se no nos dejáis soñar, no os dejaremos dormir. É poesia pura, mas que nos faz 
questionar e pensar (e por que não sonhar?) por outros modos e não como esperam que pensemos (sonhemos). Ele diz logo no início: voy a leer unas palabritas que tienem que ver con el derecho de soñar, con el derecho al delírio (...). Qué tal se deliramos por un ratito? Qué tal se clavamos los ojos más allá de la infamia para adivinar otro mundo posible? Para mim, fala da responsabilidade que temos de tentar, de buscar a realização da utopia que, como diz Fernando Birri, serve para nos fazer caminhar. Como também nos diz Joan Manoel Serrat, cantor espanhol, caminante no hay camino, se hace camino al andar, traduzindo para a música versos do poeta espanhol Antonio Machado. Não fosse a literatura, seguramente eu não teria me atrevido a sonhar, a desejar outro mundo possível, e não teria realizado coisas impensáveis se ficasse presa às convenções sociais que me foram impostas a vida inteira.

O aprendizado da literatura me levava para um mundo de compromisso com transformações, com questões sociais. Iniciativas locais, simples, que transformam, têm surgido longe das capitais, em outros países, mas o reconhecimento destas é lento, quando há. Muitas comunidades, inseridas que estão na globalização, não enxergam os próprios valores. Os poderes constituídos detêm as rédeas e é difícil encontrar brechas para novas ideias. E eu acordava aos poucos para a necessidade de que, uma vez conhecendo novos mundos e perdendo o medo de tomar certas atitudes, precisava provocar outros para me ajudarem na tarefa que aos poucos ia se tornando comunitária.

Meus interesses como estudante, como pesquisadora, estão nas periferias, nas comunidades tradicionais que guardam informações culturais importantes. Os saberes transmitidos pela oralidade, pelos fazeres locais da comunidade onde nasci e de outras com as mesmas características, a prática dos contadores de histórias que expressam muito mais do que aparentam. Conhecimentos fundamentais que retratam histórias de pessoas e seus locais de origem.

Chegar à universidade não foi o grande problema, acreditar que eu podia chegar e permanecer nela, sim. Eu estava muito segura de que meu interesse como universitária era buscar instrumentos para agir social e culturalmente com mais eficiência, mas não conhecia os caminhos. Sabia o que sempre se soube: estudar na universidade custa muito caro, e eu não tinha dinheiro. Logo de início eu percebi que a Academia queria formar pensadores, era minha primeira impressão, 
mais do que atores; mas meu caminho era o da ação. E eu fui encontrando brechas para poder dizer e ser ouvida, entendendo aquele espaço. E essa universidade vista anteriormente como lugar reservado para os de classe social e econômica muito distinta da minha, mundo apenas de ideias, foi me acolhendo e eu fui me surpreendendo com ela e comigo por conseguirmos um diálogo produtivo, uma parceria na ação emancipadora.

Hoje volto meu olhos para a cultura-mãe e, por parte dessa mãe trago algumas reflexões de sujeito atento e, inspirada em Bartolomeu Campos Queirós, conto a minha relação com a cultura oral e a cultura escrita, com a leitura como ferramenta de autonomia, de preservação da história, como instrumento de relação entre pessoas, entre mundos. Pois a literatura é também instrumento de sensibilização, de humanização.

Neste percurso, a passos largos, do meu encontro prazeroso com a leitura e a escrita está a intenção de alertar para o fato de que eu sou um ponto entre muitos que se sucedem no nosso Brasil para além das capitais. Que meu nome é apenas um na legião de possíveis leitores perdidos no caminho. Que se não somos um país de leitores uma das razões é que o livro não é disponibilizado sem misticismos, sem rapapés. Na nossa cultura o livro ainda é um instrumento a ser utilizado com todos os não-me-toques, disponível para iniciados. Lembro-me de que eu passava todos os recreios, enquanto estudei no Colégio da cidade de Inhapim, nos idos de 1980, tímida, encostada na parede esperando o sinal de retorno à sala de aula. A biblioteca nunca me foi apresentada como lugar de leitura agradável, de descanso, de manuseio livre do livro. Sempre foi mais importante a organização dos livros nas estantes e não o seu uso. Ainda hoje é assim que é a maioria das bibliotecas, inclusive as escolares. As palavras de Nanci Nóbrega dizem do que é fato. Biblioteca é vista como templo.

A biblioteca é um templo onde os segredos devem ser ritualizados e transmitidos para e por alguns poucos, a fim de que o mistério continue. É um fazer de consagração, tão impregnado no imaginário social que ainda hoje as bibliotecas são vistas só assim pela maioria de nós. Diante disso, surge o contraponto daquele outro agir social, tático, do cotidiano: o esvaziamento de tal magnitude por meio dos jogos dos discursos sociais. (Conta-se que um homem, ao passar diante da escadaria da Biblioteca Nacional, no Rio de Janeiro, subiu os primeiros degraus e, ajoelhando-se constrito, fez o sinal da cruz). (NÒBREGA, 2002, p. 121) 
Tanta cerimônia afasta o potencial leitor. Tanto cuidado, legítimo com vistas à preservação do acervo, intimida, soleniza o encontro do leitor com o livro, principalmente nas bibliotecas ditas públicas. Quando não se tem desde criança interação com o livro, o jornal, e outras ferramentas de leitura, esta relação precisa de amparo, condução. Pensando assim, no Clubinho de Leitura, fazemos questão de que o livro esteja à altura dos pequenos, ao alcance da mão e dos olhos dos que passam por lá. De bebês a vovôs e vovós que chegam são bem chegados, como se diz lá no interior. É preciso encorajar o leitor principiante, é necessário confiar na sua capacidade de lidar com o objeto livro e dele tirar proveito, ou distrair-se apenas. Há que começar.

Se ler é ler nas dobras, nos desvãos talvez/sempre existentes, se o leitor se inscreve e co-escreve no ato mesmo de ler; se, inseridos os acervos pessoais e coletivos, possibilitam-se os acervos sociais e legitimam-se os acervos institucionais; se, inseridos os acervos literários, constroem-se com a potência expressiva da palavra, conhecimentos com asas e raízes - podemos ver com mais clareza que esta práxis é eminentemente argumentação. Aquela já referida, que pressupõe o outro e, assim, instaura a interlocução, o diálogo. (NÒBREGA, 2002, p. 128)

O prazer da leitura está mesmo no desconforto causado pelo novo. O acontecimento estético, a comunicação leitor/livro se dá no ato do encontro. Há uma dimensão transgressiva na experiência da leitura, nas palavras do professor de psicologia, Joel Birman, um momento em que o leitor se permite ir além do lugar onde se encontra. Atualiza-se.

O leitor é desconcertado pela leitura que o desarruma nos seus sistemas de referência. Um certo livro não passa em branco para um leitor determinado justamente quando um experiência desconcertante desta ordem se realiza. Somente as páginas plenas de sinais gráficos passam a ser escritas com palavras ressonantes. Algo da ordem da provocação aconteceu, pois o desejo do leitor é colocado em movimento mediante um fragmento do texto. Com isso, ele se descobre, pela experiência da leitura, como um sujeito desejante, de forma que ela the possibilita uma intuição e até mesmo um conhecimento de si mesmo antes inexistente. (BIRMAN, 1994, p. 104)

A leitora que me tornei por sorte, por destino, pois, encontrando o espaço para o contato com a arte, com o poder de transgredir, de ultrapassar barreiras sociais, justamente quando e onde ocupava um lugar do desprestígio, do trabalho subalterno, é que tive valorizado o meu poder de criar. É certo que havia o meu desejo desde muito antes, mas desejos dessa natureza na maioria das vezes são 
soterrados pela contingência, por serem percebidos como desnecessários à sobrevivência. Não se morre por falta de leitura, de contato com arte, por não desenvolver-se culturalmente. Será?

Por ter as portas do conhecimento abertas pela prática da leitura, posso hoje ter consciência de quem sou, do que quero ser, e de que posso contribuir para mudar o mundo, ainda que este mundo seja a minha própria casa, chegando à minha vizinhança, meu círculo de amigos. Que aprendi que as histórias ouvidas em volta do fogo ainda na infância me marcaram tanto porque trazem, ao modo de fantasia, as experiências primeiras do mundo duro e cruel. Que reconheço que a nossa força enquanto povo daquela comunidade específica, o Córrego dos Januários, está centrada na nossa simplicidade de gente da roça, na forma como recebemos os visitantes, a forma de contarmos nossas histórias, e que quanto mais genuínos, mais fortes como comunidade, e assim nossa cultura se fortalece, se renova e, creio, perpetua.

Depois de fazer todo um percurso entremeado de muitas histórias vividas por mim e muitos companheiros de estrada, todos os caminhos me levam a lidar com a expressão emancipação social. E para discutir esse tema trago para a nossa prosa o sociólogo português Boaventura de Souza Santos (2007), tendo como base para nossa discussão o seu livro "Renovar a teoria crítica e reinventar a emancipação social"'.

\begin{abstract}
"Renovar a teoria crítica e reinventar a emancipação social" nos revela, de imediato, que a capacidade de síntese densa, engendrando crítica e anúncio, somente pode resultar de autores abertos ao debate teórico e com compromisso ético-político com as lutas de movimentos e organizações sociais e políticas, que apostam não apenas na emancipação política, mas, sobretudo, na emancipação humana e social. Vale dizer, comprometidos com a práxis transformadora ou revolucionária das relações sociais, cada vez mais violentas, do capitalismo realmente existente, em especial nos países de capitalismo dependente e associado. (p. 07)
\end{abstract}

Por percebê-lo sensível às questões com as quais venho lidando, os embates sociais, as tentativas de ações com potência transformadora, tomo suas ideias como ponto de partida para refletir sobre todo um percurso vivido pelos moradores do Córrego dos Januários, que só foram possíveis por que o acesso ao conhecimento foi viabilizado. Não falo aqui do meu aprendizado, do meu percurso pessoal, falo das condições para o encontro, das possibilidades tramadas 
pelo universo que fizeram com que uma comunidade tão resguardada nos interiores de Minas fizesse ponte, culturalmente falando, com pessoas de outras regiões do Brasil. A transformação no nível da consciência que leva à ação. E o que me leva a pensar não são as ações com caráter heróico, falo do dia-a-dia das comunidades, no agir de pessoas comprometidas com seu entorno, conquistas através de atos conjuntos, de parcerias que vão se organizando para solucionar problemas locais reverberando para além das divisas sejam elas quais forem. E pensando na extensão do país de onde falo, mais cuidado se faz necessário, pois muitas comunidades são esquecidas pelo poder público que deveria gerir todas as regiões que compreendem o nosso mapa. Penso no tema da emancipação social como o tema de ascensão de toda uma cultura. Quando temos acesso aos bens culturais, quando reconhecemos os laços que nos constituem como nação e deles usufruímos, maiores são as possibilidades de contribuirmos, como cidadãos, para uma nova ideia de sociedade. Uma sociedade forte pelo caráter de unidade na multiplicidade.

Penso que a questão social é um tema complicado. A cultura do medo nos impede de avançar. $\mathrm{Na}$ atualidade os caminhos são muitos, uma vastidão de possibilidades, mas poucos conseguem. Por que? Estamos ainda presos a sistemas de estudo, de vida, de observação dos fenômenos sociais que vêm dos centros hegemônicos; ainda pensamos em pobres e ricos, em quem manda e quem obedece. Uma sociedade assim periga estagnar, e continuar falando em democracia. As histórias que trago nessa minha narrativa, nesse fio de memórias de experiências transformadoras, comparecem na intenção de mostrar que é possível fazer o mundo de formas diferentes. Souza Santos traz um novo olhar para esta questão, mostra a necessidade e a possibilidade de descentralizar os comandos, as diretrizes das sociedades hoje globalizadas. As experiências não coincidem mais com as expectativas, diz Boaventura.

O problema é que emancipação social é um conceito absolutamente central na modernidade ocidental, sobretudo porque esta tem sido organizada por meio de uma tensão entre regulação e emancipação social, entre ordem e progresso, entre uma sociedade com muitos problemas e a possibilidade de resolvê-los em outra melhor, que são as expectativas. Então, é uma sociedade que pela primeira vez cria essa tensão entre experiências correntes do povo, que às vezes são ruins, infelizes, desiguais, opressoras, e a experiência de uma vida melhor, de uma sociedade melhor. Isso é novo, já que nas sociedades antigas as experiências coincidiam com 
as expectativas: quem nascia pobre morria pobre; quem nascia iletrado morria iletrado. Agora não, quem nasce pobre pode morrer rico, e quem nasce numa família de iletrados morrer como médico ou doutor. (p. 17-18)

O mundo não é dicotômico, é plural. Sempre foi organizado numa dicotomia Sul/Norte, mas as regras do jogo estão mudando, e é preciso considerálas. Desprezar as experiências que não partem dos grandes centros, que surgem das periferias, é reduzir muito as possibilidades de compreensão do que vem ocorrendo. É ignorar a nova ordem. Hoje todos "podem”, em termos. Há possibilidades de exercer esse "poder", mas estas estão muitas vezes camufladas. Resiste-se muito a integrar ações que eu nomearia "proativas", que estão acontecendo para evoluir-se nesta questão, mas são, penso eu, a saída para muitas querelas sociais. Hoje está tudo muito misturado, quase um vale tudo, mas é preciso haver ordem, no sentido de organização, de respeito e valorização das vozes das ruas. Boaventura põe em campo um projeto ousado, a meu ver.

Hoje vivemos um problema complicado, uma discrepância entre teoria e prática social que é nociva para a teoria e também para a prática. Para uma teoria cega, a prática social é invisível; para uma prática cega, a teoria social é irrelevante. E essa é a situação que temos de atravessar se tentamos entrar no âmbito da articulação entre movimentos sociais. (...) Não necessitamos de alternativas, necessitamos é de um pensamento alternativo às alternativas.

(...) Foi nesse contexto que propus um exercício: reunir cientistas sociais do Sul e tentar realizar um projeto que se chamou: "Reinventar a emancipação social a partir do Sul" (ou seja, dos países periféricos e semiperiféricos do sistema mundial), para permitir que as ciências sociais se reunissem e organizassem internacionalmente fora dos centros hegemônicos. (p. 20-21)

Este exercício envolve seis países: Portugal, Colômbia, Brasil, África do Sul, Índia e Moçambique, com cerca de sessenta pesquisadores estudando e produzindo conhecimento a partir do Sul e não do Norte, como ele diz. Deste estudo estão sendo produzidos 5 livros: Democratizar a democracia, Produzir para viver, Reconhecer para libertar, Semear outras soluções, Trabalhar o mundo. Ao que me parece, a julgar pelos títulos, tratam de novos paradigmas.

Há cinco formas de ausência que criam essa razão metonímica, preguiçosa, indolente: o ignorante, o residual, o inferior, o local ou particular, e o improdutivo. Tudo o que tem essa designação não é uma alternativa crível às práticas científicas avançadas, superiores, globais, universais, produtivas. Essa ideia de que não são críveis gera o que chamo a subtração do presente, porque deixa de fora, como não existente, invisível, "descredibilizada", muita experiência social. Se queremos inverter essa situação por meio da Sociologia das Ausências, temos de fazer que o 
que está ausente esteja presente, que as experiências que já existem mas são invisíveis e não-críveis estejam disponíveis; ou seja, transformar os objetos ausentes em objetos presentes. Nossa sociologia não está preparada para isso, não sabemos trabalhar com objetos ausentes, trabalhamos com objetos presentes; essa é a herança do positivismo. Estou propondo, pois, uma Sociologia insurgente.

Se é assim, essa falta, essa ausência, é um desperdício de experiência. A maneira pela qual procede a Sociologia das Ausências é substituir as monoculturas pelas ecologias. (p. 32)

Quando o sociólogo fala do desperdício da experiência, me faz lembrar Walter Benjamin. Em $O$ Narrador, Benjamim escreve sobre a iminência da "morte" da experiência na modernidade. Ao descartar as experiências diversificadas em favor da hegemônica perde-se em inovação, em transformação de fato da sociedade, pois não é de se esperar que alguns locais deem conta do global. E nós acreditamos nisso desde sempre. Benjamin afirma que a falta de experiência no mundo moderno afeta a possibilidade de narrativa, Santos escreve que o reconhecimento da diversidade de experiências apontaria para a real possibilidade de descentralização do comando e modernização das sociedades. Experiências de comunidades periféricas, falo agora não relacionado aos grandes blocos citados por Santos, mas das pequenas comunidades dentro desses grandes blocos; que as pequenas ações é que de fato transformam. É o que ele traz à baila com o conceito de sociologia das ausências. Estaríamos, segundo ele, vivendo numa superfície onde o que está presente é o que é ditado pelo mercado, pelo pensamento político e social de alguns poucos países, mas o que está ausente, nas periferias, nos lugares de desprestígio cultural e social, seria o grande agente de nudanças. Penso que ele não propõe este contra aquele modo de se construir conhecimento, mas propõe mesmo uma outra coisa. É como se dissesse: esqueçamos o que vem sendo feito e implantemos um jeito novo, um novo olhar para as questões que o mundo impõe. Para ele, a monocultura do saber e do rigor, privilegia o saber científico em detrimento de outros.

Essa monocultura reduz de imediato, contrai o presente, porque elimina muita realidade que fica fora das concepções científicas da sociedade, porque há práticas sociais que estão baseadas em conhecimentos populares, conhecimentos indígenas, conhecimentos camponeses, conhecimentos urbanos que não são avaliados como importantes ou rigorosos. (p. 29)

Ao falar das monoculturas vai mostrando como as sociedades estão subjugadas sem uma possibilidade de emancipação que leve em conta 
conhecimentos variados, ainda que não estejam dentro do rigor científico. Tratando da monocultura do tempo linear, por exemplo, ele levanta a questão das diferentes temporalidades levando-se em conta as distintas culturas. $\mathrm{O}$ tempo do indígena é diferente do tempo do hindu, que é diferente de outros mais. Mas todos são colocados dentro de uma mesma caixa temporal e devem produzir segundo as diretrizes dos países que estão na dianteira, pois eles determinam o tempo ignorando outras dimensões do mesmo. Souza Santos menciona ainda a naturalização das diferenças, que considera que os países que detêm a hegemonia cultural, política, econômica e social dominam a periferia que seria inferior por natureza. O produtivismo capitalista que também ignora modos diversos de produção, é outra questão.

A realidade particular e local não tem dignidade como alternativa crível a uma realidade global, universal. O global e universal é hegemônico; o particular e local não conta, é invisível, descartável, desprezível. (p. 31)

Essa é, a meu ver, a grande questão de Boaventura neste texto $O$ local $e$ o global, a hegemonia de um sobre o outro.

As ecologias que ele descreve também apontam para a necessidade de valorização de conhecimentos que estão pulverizados tanto nos centros como nas periferias. Seria a ecologia contra a monocultura dos saberes, das temporalidades, do reconhecimento, da transescala e das produtividades. A grande virada que ele propõe é essa: a mudança de perspectiva do modo e de onde se produz o conhecimento hoje.

A ecologia dos saberes. Não se trata de "descredibilizar" as ciências nem de um fundamentalismo essencialista "anticiência"; como cientistas sociais, não podemos fazer isso. O que vamos fazer é um uso contra-hegemônico da ciência hegemônica. Ou seja, a possibilidade de que a ciência entre não como monocultura mas como parte de uma ecologia mais ampla de saberes, em que o saber científico possa dialogar com o saber laico, com o saber popular, com o saber dos indígenas, com o saber das populações urbanas marginais, com o saber do camponês. Isso não significa que tudo vale o mesmo. (...) Vamos iniciar, nesta ecologia, afirmando que não é ver como o conhecimento representa o real, mas conhecer o que determinado conhecimento produz na realidade; a intervenção no real. Estamos tentando uma concepção pragmática do saber. Porque? Porque é importante saber qual é o tipo de intervenção que o saber produz. (p. 32-33)

$\mathrm{Na}$ verdade o que se propõe é romper a muralha que impede o reconhecimento das diversas culturas e seus modos de sobrevivência e produção 
de conhecimento. Desfazer a ideia de se oferecer as sociedades de periferia como campos de estudos dos centros hegemônicos que, uma vez detentora das informações, produz uma ciência segundo suas concepções, que dita, que conclui e exporta para o resto do mundo dentro da sua lógica de comando. É repudiar a ideia de "pirataria consentida" que manipula e expropria o conhecimento produzido nas periferias.

As ideias de Boaventura parecem um tanto utópicas, mas são, a meu ver, a saída. É tentar ver e construir o mundo de um outro modo.

E Boaventura vem ratificando ideias que, como já disse, vêm tomando corpo nos locais desprestigiados, abandonados pelos centros. A forma com que se tem tratado as questões mundiais, como um bloco, impede que se olhe para os particulares. Ou seja, é necessário que acordemos para a realidade que se apresenta, e reavaliemos os modelos ultrapassados.

Todo meu diálogo com essas ideias que julgo fundamentais para minhas reflexões tem como fio condutor a possibilidade de transformação por iniciativas autônomas, enraizadas na necessidade que cada povo tem de se relacionar com o meio social onde vive. É necessário, creio, uma mudança radical, mas essa mudança exige uma aposta verdadeira na possibilidade de fazer de outro modo. E a mudança parte dos interessados. Se queremos mudar, mudemos. O que ocorre é que sempre as mudanças são possíveis quando lutamos contra alguma coisa, pois a história de dominação vem desde que o mundo é mundo, e implantar novos paradigmas é cansativo. É necessário rebeldia. É necessário vontade, e aí é que

Estamos diante de um grande problema: como intensificar a vontade. Em outras culturas é mais fácil. Provavelmente vocês se lembram de filmes da China ou da Índia em que, com uma concentração de ioga, os personagens podem, por meio de uma intensificação enorme da vontade, destruir um pedaço de madeira com a mão. Ou seja: não há condições objetivas se a vontade é forte. Em nossa cultura, ao contrário, não temos possibilidade disso; nossa vontade está muito relacionada às condições objetivas, o que não me pareceria mal se complementássemos com outra reflexão que as ciências sociais têm deixado de fora: a distinção entre ação rebelde e ação conformista. Estou mais interessado nessa distinção e em como criar subjetividades rebeldes do que em ficar discutindo os conceitos de estrutura e ação a vida toda. (p. 24)

O que me leva de novo ao meu diálogo com Marcelo, lavrador, pai de família, homem simples da roça, reconhece em si como valor, e lhe permite orgulhar-se do homem decente que é são suas qualidades de pessoa íntegra, 
honesta, respeitadora e consciente de que está mudando, de que tem sentimentos. Porque

não há nenhuma cultura que seja completa, e então é preciso fazer tradução para haver a diversidade sem relativismo, porque os que estamos comprometidos com mudanças sociais não podemos ser relativistas. Mas é preciso não captar toda a riqueza para não desperdiçar a experiência, já que só sobre a base de uma experiência rica não desperdiçada podemos realmente pensar em uma sociedade mais justa. (p. 41)

Enfim, a ideia é mover o eixo, mudar, apostar em alternativas. Santos pensa em sociologias e ecologias, o que me faz pensar em partilha, em multiplicidade, possibilidades de perceber a sociedade por muitos prismas, valorizando outros saberes que não os cristalizados pelas teorias das regiões dominantes. A valorização de saberes de sociedades com crenças e fazeres distintos. É nessa vertente que venho pensando.

E pensando assim é que ao vislumbrarmos um universo a ser explorado tendo como ponto de partida para nossas ações a Casa de Memória e Cultura do Córrego dos Januários e o Clubinho de Leitura. Hoje a nossa equipe de trabalho está composta por mim, licenciada, quase mestra em Letras e coordenadora geral e orientadora das atividades; Edervanio, psicólogo; Dayane Ribeiro, com formação em técnica ambiental; Edilaine, técnica agrícola; Saulo Guedes, músico de primeira qualidade; Rita Dias é professora pós-graduada em matemática e Branca é professora e proprietária de uma escola de Educação infantil. E ainda contamos com Adélia Pereira, professora, que nos apoia em mil e uma situações além de manter a Casa organizada e receber os visitantes quando solicitada. Somos poucos, conhecemos nossas limitações, mas sabemos também que podemos nos mover e mobilizar outros para juntos pensarmos em alternativas que levem melhorias para o nosso Córrego dos Januários, mas também para mantermos acesa a ideia de que um mais um é sempre mais que dois, encontrarmos soluções para nossos problemas. 


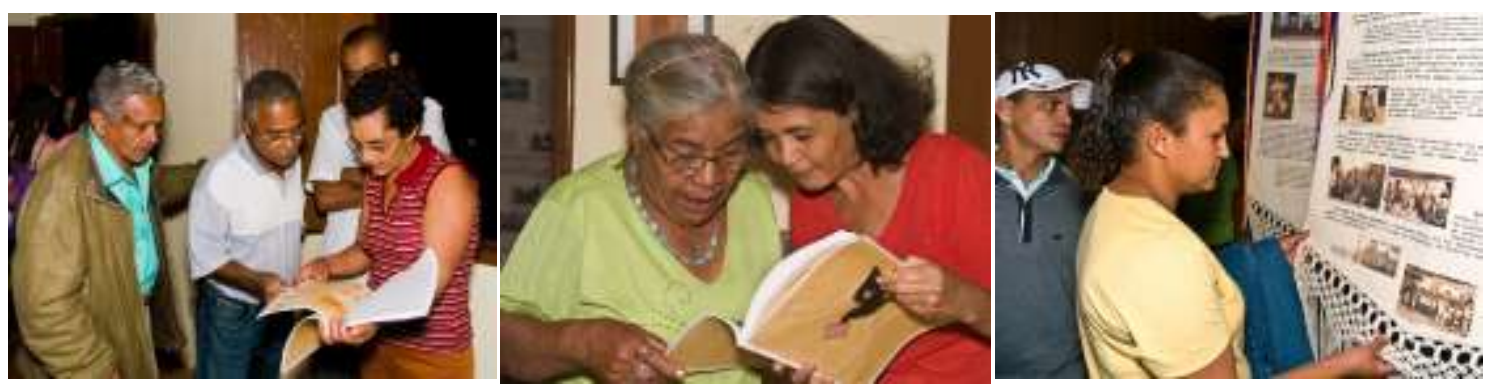

Figura 135: Inauguração da Casa de Memória e Cultura, Antônio, João Donato, Julio e Mônica Figura 136: Adriana e Eulália

Figura 137: Rosália e Sebastião (Fotos de Ana Andrade)

As palavras de Dorvalina, minha irmã, professora ao ver a casa de nossos pais entregue à comunidade, expressa o que significa todo o processo pelo qual a comunidade passou.

A comunidade teve a oportunidade, através da Denise e da Toquinha, de entrar em contato com pessoas (ligadas à cultura) que valorizaram a nossa cultura. Isso é maravilhoso. A comunidade se sente importante e aprende muito. Quando as crianças do Clubinho estiveram no PUC PELA PAZ eu pude observar o quanto elas ficaram felizes por levar um pouco da história do Januário para uma das mais importantes universidades do país. Não tenho nem palavras para expressar o que sinto vendo isso acontecer. Gostaria que essas crianças não deixassem de valorizar suas raízes, assim como está fazendo a Toquinha. Nossos pais e avós não fizeram faculdade, mas a sabedoria que eles nos transmitiram é um legado que passará de geração em geração, É uma coisa muito sólida. Foi muito bom receber os cartões postais, foi ótima a experiência de compartilhar das nossas historias e dos momentos bons que já vivemos, com pessoas que sem essa oportunidade, nós nunca iríamos conhecer. (GUSMÃO, 2009, p. 271)

Muitos se surpreendiam ao se ver ou ver pessoas muito próximas sendo o foco da exposição. E quase não acreditávamos que havíamos conseguido realizar obra tão importante. O reconhecimento de cada um estava estampado no rosto, na leitura compenetrada. As palavras de Paul Ricoeur sobre o reconhecimento na linhagem fecham essa etapa da minha reflexão, pois pessoas que estão lendo o painel que conta a minha história junto à fotografia de meus pais são todos meus parentes, e como tal sinto-me parte de uma família e sou reconhecida como tal, de valor inestimável. 


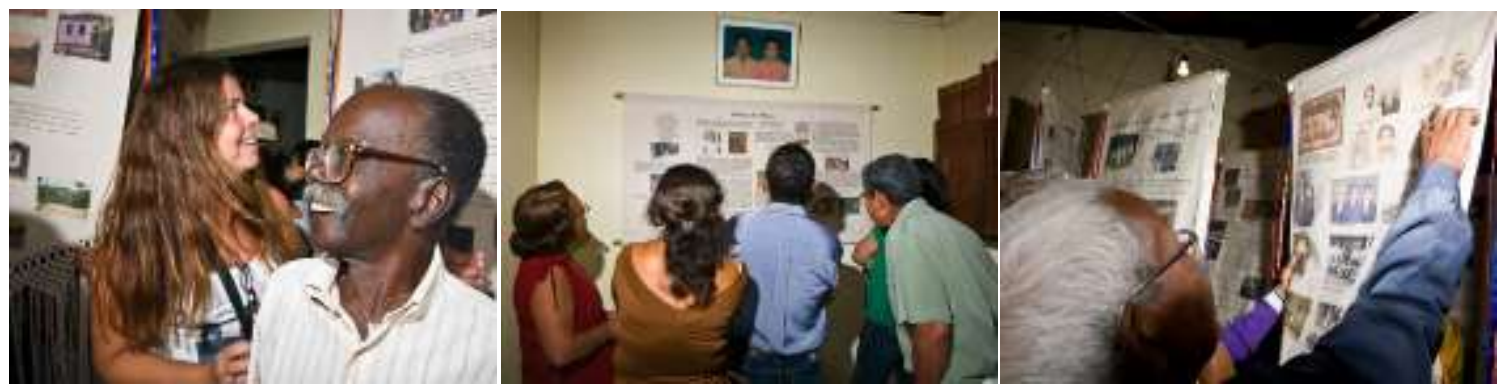

Figura 138: Inauguração da Casa de Memória e Cultura, Denise e Seu Genorinho Figura 139: Inauguração da Casa de Memória e Cultura, Maria José, Virgínia, Betinho e Lucas Figura 140: Inauguração da Casa de Memória e Cultura, Tio Cândido (Fotos de Ana Andrade)

Concentrando-me na significação que tem para mim essa identidade civil, descubro com surpresa que antes de poder pensar em mim mesmo e de ser sujeito da percepção, de ação, de imputação, de direito, fui e continuo a ser esse "objeto", essa res, que Pierre Legendre denomina, no título de seu livro, "esse inestimável objeto de transmissão". O epíteto "inestimável" me intriga: meu nascimento fez de mim um objeto sem preço, fora de preço, essa coisa que está fora do comércio ordinário. $\mathrm{O}$ projeto parental do qual provim - qualquer que tenha sido transformou a estática do quadro genealógico em uma dinâmica instituidora que se inscreve na palavra "transmissão": transmissão da vida, ela própria instituída como humana pelo princípio genealógico, transmissão pela legenda familiar, transmissão de uma herança de bens mercantis e não mercantis, transmissão, por fim, resumida na atribuição de um nome: eu me chamo..., meu nome é... É essa contração do tesouro da transmissão na nominação que permite falar pela primeira vez em reconhecimento na linhagem: fui reconhecido(a) filho(a), qualquer que seja o rito familiar, civil ou religioso que possa escandir esse reconhecimento de que fui objeto pela primeira vez. Os romanos tinham uma instituição apropriada para esse acontecimento: a adoção, que autorizava, no sentido forte da palavra, a pronunciar essa expressão performativa admirável. Titus, seja meu herdeiro... Em um certo sentido todo nascimento acolhido é uma adoção, não apenas pelo pai, mas também pela mãe, desde o instante em que ela aceitou ou escolheu manter esse feito que se tornou "seu" bebê e dar-lhe nascimento. Ambos foram autorizados pelo sistema a transmitir-me um patrimônio e a escolher um nome para mim, como compensação para essa autorização para me nomear, eu sou autorizado a continuar a transmissão, em nome daqueles que fizeram de mim seu herdeiro, e a ocupar no momento apropriado o lugar do meu pai e da minha mãe. Enfim, como fui reconhecido filho ou filha de, eu me reconheço como tal, e, a esse título, esse inestimável objeto de transmissão sou eu. Graças a essa interiorização progressiva do olhar genealógico, o ego, função zero no quadro dos lugares, torna-se função plena quando a transmissão é vivida como reconhecimento mútuo, ao mesmo tempo parental e filial. (RICOEUR, 2006, 207-208)

Com essas palavras assumo o lugar no qual fui reconhecida, o de ser parte, de pertencer, de não estar só.

Ao inaugurarmos, em 2008, a Casa de Memória, inauguramos também um novo tempo, novas expectativas. O que fomos realizando sem consciência suficiente se daria certo, se era aquele o caminho, demonstrou pela prática, que tínhamos, como comunidade, autonomia para construir uma nova história, novas 
perspectivas. E é preciso dizer que vontade só não dá conta. A trajetória de formação social, cultural e política facilitam o trabalho dos que se embrenham pelas florestas espessas do desconhecimento construindo trilhas por onde se possa chegar ao destino projetado. Se nós tivéssemos conhecimento suficiente, se tivéssemos preparo, nosso caminho seria menos angustiado. Mas os caminhos foram abertos. Temos hoje em dia, como equipe de trabalho e como comunidade, a consciência de que apenas abrimos a porta, mas que ao abrirmos a porta havia do outro lado um mundo de possibilidades.

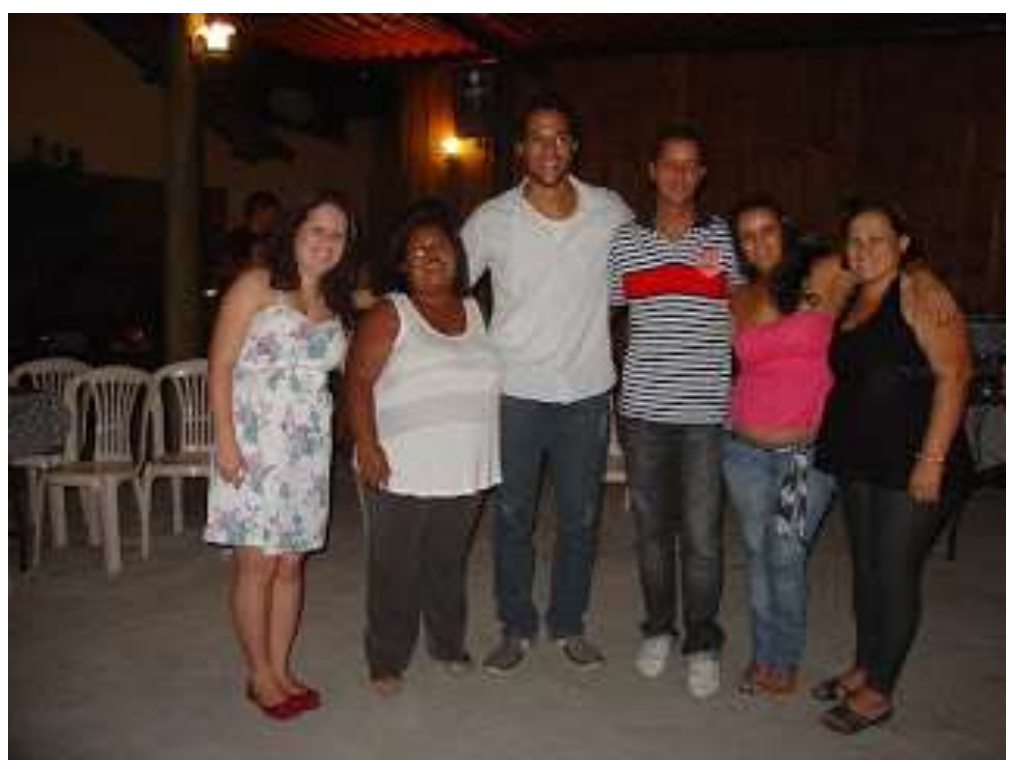

Figura 141: Dayane, Toquinha, Saulo, Edervanio, Rita e Branca 


\title{
7 \\ Considerações finais
}

\author{
A raça humana é \\ Uma semana \\ Do trabalho de deus \\ A raça humana é o cristal de lágrima \\ Da lavra da solidão \\ Da mina, cujo mapa \\ Traz na palma da mão \\ (...) \\ A raça humana risca, rabisca, pinta \\ A tinta, a lápis, carvão ou giz \\ $O$ rosto da saudade \\ Que traz do gênesis \\ (Gilberto Gil)
}

Ao fim desse percurso em que conto as peripécias do trajeto entre o Córrego dos Januários e o Rio de Janeiro, sinto que cada história recuperada, cada palavra de cada pessoa, as canções e os poemas me fizeram enxergar com mais clareza o solo fértil dos encontros. Ao nomear os companheiros, personagens dessa jornada de aprendizados, de intercâmbio de saberes, a possibilidade de expandir os horizontes. De encontrar na delicadeza e na escuta tão caras à Denise Gusmão, a sua estética da delicadeza, as ferramentas para o trabalho na seara das memórias.

O tempo da delicadeza talvez seja esse tempo em que vislumbramos o futuro no presente, de "olhos dados" com o passado. Um tempo em que pensamos nos que ainda vão nascer e nos comprometemos com os "vindouros" aqui e agora. O tempo da delicadeza é também um tempo de escuta. De sermos testemunhas, ouvintes de experiências que se não ouvirmos podem ficar para sempre esquecidas. Há tanta gente no mundo hoje esquecida. (2009, p. 90)

A delicadeza que Zilda reconhece ao se lembrar da mãe, D. Ercilha, e de sua vontade de contar também.

Zilda: Ela que contava pra nóis. Então, tomava o banho, jantava, só sei que nóis deitava na cama, eu, a mãe e a Denise, a mãe ficava contano história pra nóis. Mas, eu num sei, minha mãe num tinha livro não... E num foi uma nem duas não, é muitas! Sei lá, parece que ela sentia assim um prazer de ficar, de deitar com nóis... parecia que tinha aquele prazer assim de ficar contano, né, a paciência. E aquilo eu pegava dela e saía contano pr'oceis. (risos) Ih, mas era o meu prazer! Chegar na escola e contar... dicocava (ficava de cócoras) tudo em roda de mim pra escutá!

Além das histórias, Zilda recorda que era na barra da saia das mães, sob os olhos da família que éramos criados, que aprendíamos o necessário para tocar a 
vida. Ainda que esse aprendizado fosse o de, ao lavar a roupa, deixá-la quarar, dar uma esquentadinha...

Zilda: e ficava ali as mãe ensinano, e as filha ali... portanto até hoje eu gosto de esquentá as minhas roupa assim num plástico, numa graminha assim... porque o meu ensinamento foi esse. Porque hoje em dia muita gente passa a mão na roupa e... não... mas não é bão dá uma esquentadinha?

Essas memórias evocadas vão nos recompondo como povo, nos alertando para a necessidade de tomarmos as rédeas da nossa história como comunidade e cada um como pessoa, nos mostrando que somos parte de uma engrenagem maior, mais robusta que se sustenta com as pequenas peças que somos.

A Casa de Memória e Cultura, o Clubinho de Leitura, as bibliotecas populares de Rosário, e as independentes, se mostram como espaços de construção e afirmação de identidade, de reconhecer o lugar do outro, de vivermos a ideia de comunidade ainda que os espaços onde vivemos estejam fragmentados.

E quase no apagar das luzes, vi em um post, no facebook da Biblioteca Popular Cachilo, uma história que me encantou profundamente, de um professor colombiano chamado Luis Humberto Soriano Bohórquez. Ainda que entendamos todos os percalços pelos quais passa o professor que inventa uma biblioteca ambulante, a Biblioburro, há muita consciência, trabalho e poesia nas suas palavras, nas suas ações. A ideia que mesmo para sua mãe parecia absurda, quando, no documentário, ela conta a saga do filho, professor da comunidade de La Glória, Nueva Granada/Colombia,que leva o conhecimento no lombo dos burros Alfa e Beto, aproximando livros e campesinos, pontes para o conhecimento, nas regiões violentas da Colômbia.

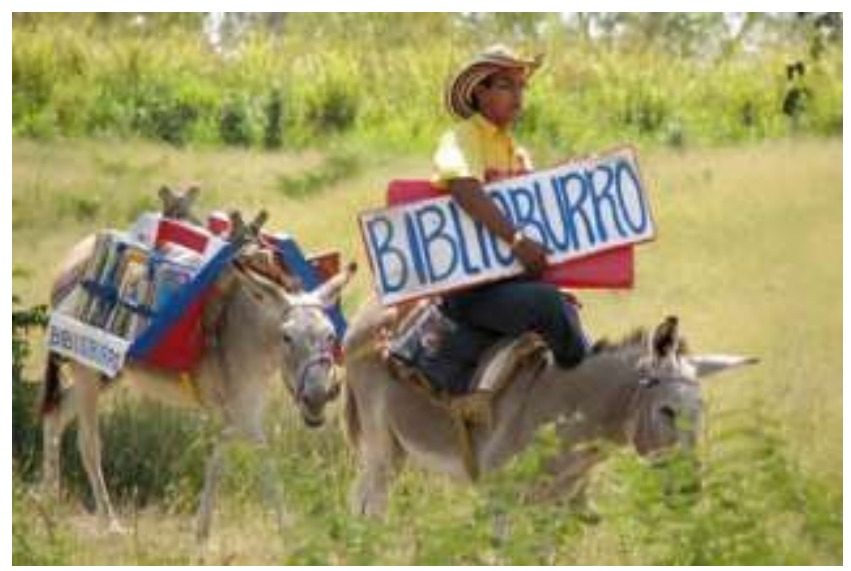

Figura 142: Luis Humberto Soriano Bohórquez 
Mi nombre es Luis Soriano Bohórquez. Soy maestro de la escuela ruralista de $L a$ Gloria. De la cabezera de la municipalidad de Nueva Granada. Y soy la persona que conduce a través de estos campos la biblioteca rural itinerante Biblioburro. Quando yo estava estudiando me gustava mucho la biblioteca. Era como um punto escondido del: hoy no hay comida, tenes que hacer las tareas, tenes que orar, tenes que ir para el colégio, tenes que ir para el culto...

Mãe: el se perdia de la casa y se lo encontrava en la biblioteca. Entiende? Eso le agradava a él. Y el seguió con su mente hasta allá.

Luis Soriano: Yo descubro a que les devemos llevarles cuentos a los niños. Porque se ellos no tienen biblioteca, hay que inventar una. Hay que llevarselas allá. Esto niño del monte, no hay biblioteca, hay que llevarse la biblioteca allá.

Mãe: él se engenió los burriquetes, puso los libros y hizo unas cosas que puso: Biblioburro. Entonces, el burro se llama Beto, y la burra se llama Alfa. Le puso Alfa, despues puso Beto. Ah, lo que eso quiere decir? ah, Alfabeto, los burros.

Luis Soriano: Alfa es practicamente la que lleva toda la biblioteca, cento veinte títulos cargamos en esta biblioteca para que se los disfruten los niños en los campos. Hemos recorridos de 3, 4, 5, 6, 7, 8 y $9 \mathrm{~km}$, hasta de $11 \mathrm{~km}$. Son 8 horas. Inicié este proyecto escolar que hace 10 años, ayudando variados estudiantes a solucionar sus tareas, en las casas; que no tenian libros en sus casas. No podian investigar, no podian hacer tareas, no podian hacer nada.

Profesora Madelis España: Biblioburro es un medio de trasporte que tiene el profesor de traer los libros en dos burros y el se emplaza por diferentes veredas a llevarles los cuentos, llevarles libros y muchas cosas importantes a todos los niños de las veredas.

Luis Soriano: el criterio sobre donde deven ir los biblioburros lo tengo bien designado y bien escrito, y bien piensado. Porque los niños que vienen a las margens de la carretera veen carros lindos, ve gente que pasa, y eso te va dando algo de enseñanza. Habrá siquiera una persona que no vive por aqui y te deja algo de enseñanza. Pero los que viven de la carretera hacia adentro, a 15, a 20km, quien les enseña? Nadie.

Profesora Madelis España: él viene, nos trae libros, nos trae los cuentos, nos trae materiales, porque los niños no tienen; y los papas tampoco tienen con que comprarlos.

Luis Soriano: porque esos niños son niños que estan atravesados por una situación de violencia (...). Son niños que vieron gente ahorcada, gente muerta, mutilados. Son niños que veían a sus papas aterrorisados, se tienendo que esconder en el arroyo, son niños que de una o otra forma se quedan mudos porque creen que tambien se estan escondiendo. Que queremos nosotros? A través del Biblioburro, Alfa, Beto y yo, cambiarle la baila. Tratar de que se animen, tomen un lapis de color, tenga el mundo el color que les de la gana. Yá se rien abertamiente, no se esconden atrás de un árbol.

Criança 2: él trae cuentos, leemos los libros, y jugamos y a vezes pintamos.

Criança 3: me alegra que el profe enseña los libros y nos pone a leer. Es importante porque quando uno nos ponen a leer una carta del papa, que los papas no entienden, uno se la lee.

Luis Soriano: a traves del biblioburro se está combatendo lo que se llama la ignorancia campesina. En un libro podemos encontrar ciudades, culturas, derechos, deveres. Entonces, un niño que estamos hoy educando a traves del biblioburro lo estamos enseñando sus derechos, sus deveres, sus compromisos; y quando un niño conoce sus derechos, sus deveres, sus compromisos, es un niño formado para no a la guerra. Construyeremos el colombiano al futuro, hace 15 anos, colombianos intelectuales. (E ele mostra sua biblioteca em construção). Este es mi compromiso de vida, sentirme util a la sociedad a la que pertenesco. Aqui se vive muy bien la vida, aqui no hay violencia, que aqui en La Gloria pase a ser eso, la gloria. Este es 
un trabajo para largo plazo. Donde colombianos con mentalidad crítica, con mentalidad constructiva y con mucha inaginación. Y colorin colorado, esta história se há terminado. Abran los ojos y miren. (Transcrição selecionada do documentário Biblioburro, disponível em http://www.youtube.com/watch? $\mathrm{v}=\mathrm{tsHyN} 9 \mathrm{zj} 8$ o\#t=0 $)$.

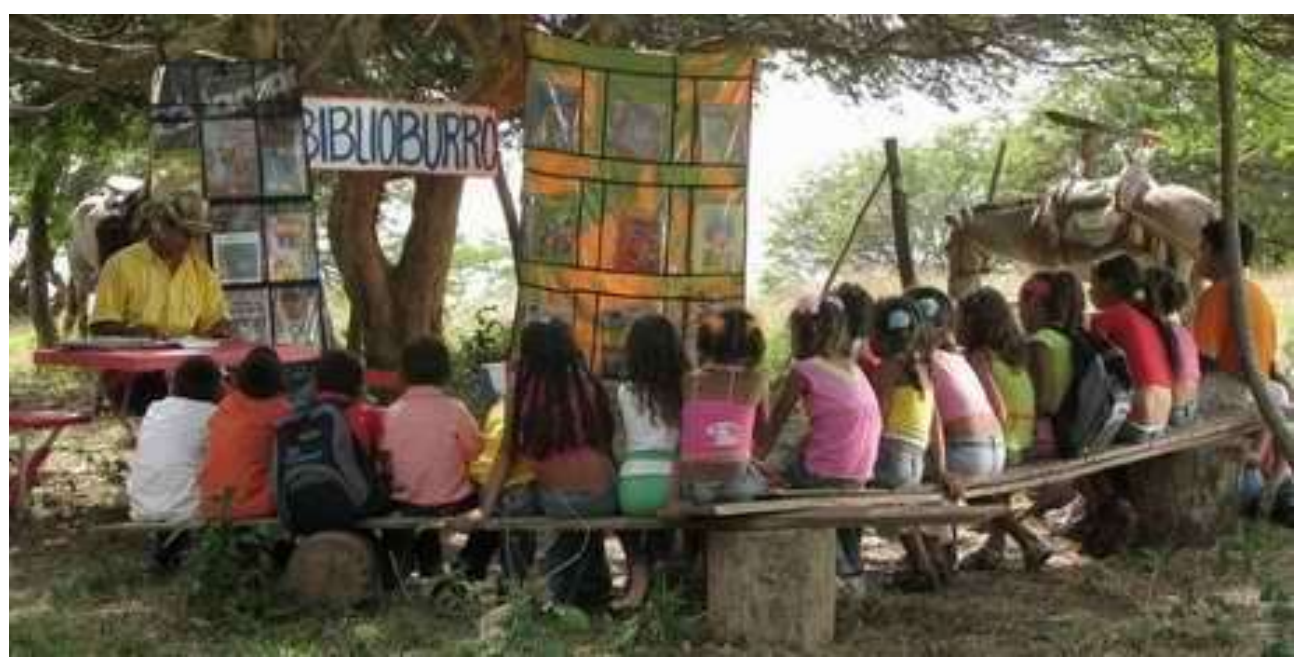

Figura 143: Luis Soriano e as crianças

Quando Luis Soriano diz: abram os olhos e olhem, está dizendo, agora vocês podem enxergar o que não enxergavam antes. Durante o vídeo se vê que ele diz isso ao fim da leitura de uma história em que as crianças estavam ouvindo com olhos fechados, mas quando ele fala abram os olhos e olhem, significa muito mais do que isso. Uma porção muito grande de afeto pelas crianças e pelo que faz.

Os que comparecem deixando sua palavra no corpo dessa narrativa nos diz que o acesso que temos, ou deveríamos ter, ao conhecimento, pode ser propulsor de novas saídas para antigos problemas, mas que o mesmo caminho não deixa as mesmas marcas em pessoas distintas. Somos massas, mas também somos únicos, e aprender a lidar com essa diversidade pode nos ajudar a perceber a grandeza do que somos e nos tornar mais humanos.

Chegando às palavras finais, percebo que é no rastro dessa simplicidade cercada de muitos ensinamentos, histórias, afetos e toda sorte de acontecidos naquela comunidade que nos coube como berço, que seguimos construindo, preparando aquele nosso pedaço de mundo, que será berço de muitos que ainda virão; e queremos que sejam felizes todos os que tenham a sorte de chegar ao mundo pousando lá pr'aquelas bandas... Um cantinho que receba os de agora e os de depois da melhor forma possível. 
Deixo para Galeano, com quem tanto tenho dialogado silenciosamente durante esses anos, a tarefa de fechar este texto, pois as histórias são muitas, mas já não há mais tempo, nem espaço para contá-las.

Quando Lucia Pelaez era pequena, leu um romance escondida. Leu aos pedaços, noite após noite, ocultando o livro debaixo do travesseiro. Lucia tinha roubado o romance da biblioteca de cedro onde seu tio guardava os livros preferidos.

Muito caminhou Lucia, enquanto passavam-se os anos. Na busca de fantasmas caminhou pelos rochedos sobre o rio Antioquia, e na busca de gente caminhou pelas ruas das cidades violentas.

Muito caminhou Lucia, e ao longo de seu caminhar ia sempre acompanhada pelos ecos daquelas vozes distantes que ela tinha escutado, com seus olhos, na infância. Lucia não tornou a ler aquele livro. Não o reconheceria mais. O livro cresceu tanto dentro dela que agora é outro, agora é dela. (2008, p. 20) 


\section{8 \\ Anexos}

\section{Anexo 1}

\section{O MACACO E A VELHA}

Era uma casa em cima do morro. A velha morava lá. Na frente tinha jardim e atrás um montão de bananeira. Perto da porta da cozinha ficava uma escada de pegar banana. A escada quebrou. As bananas estavam madurinhas.

Um macaco vinha passando e a mulher o chamou:

- Me ajuda a catar?

O macaco disse sim. Trepou pelas folhas, deu um suspiro e desabou a comer tudo quanto foi banana bem bonita.

A velha gritou:

- Safado!

$\mathrm{O}$ macaco ria.

- Pelintra!

A mulher ralhava. O macaco só jogava pra velha banana verde ou então fedida, cheia de mosca e mancha preta. Depois o macaco deu até logo e foi embora.

A velha juntou a banana que sobrou, xingando e caraminholando.

Mandou fazer uma boneca grudenta de cera. Botou na porta de casa, junto de uma cesta cheia de banana. E ficou agachada espiando.

Passou um dia. Nada.

Passou outro dia.

No terceiro, o macaco passou e sentiu um cheirinho bom. Veio chegando:

- Ô Catirina! Quero banana...

A boneca nem se mexeu. No céu, um sol de rachar.

$\mathrm{O}$ macaco pediu outra vez. A boneca quieta. O macaco falou grosso:

- Me dá uma banana, ô Catirina, senão leva um tapa.

A boneca nada e ele - pá - deu e ficou com a mão colada no beiço da moça de cera.

- Larga minha mão senão leva um beliscão!

A boneca nem ligou. $\mathrm{O}$ macaco deu e ficou com a outra mãos presa.

- Me solta, ô Catirina! Me solta senão toma um chute!

Esperou que esperou. Meteu o pé e ficou mais grudado ainda.

- Diaba! Moleca! Me larga, ô Catirina! - berrou o macaco preparando outro pé.

Chegou a velha arregaçando os dentes:

- Agora você me paga!

Levou o macaco lá dentro e mandou a cozinheira preparar o coitado pra comer na janta.

A empregada foi e fez.

$\mathrm{Na}$ hora de matar, o macaco revirou os olhos e cantou:

Me mata devagar

Que dói, dói, dói

Eu também tenho filhos

Que dói, dói, dói

Na hora de esfolar, o macaco cantou:

Me esfola devagar

Que dói, dói, dói

Eu também tenho filhos

Que dói, dói, dói

$\mathrm{Na}$ hora de temperar, o macaco cantou: 
Me tempera devagar

Que dói, dói, dói

Eu também tenho filhos

Que dói, dói, dói

Na hora de assar, o macaco cantou:

Me assa devagar

Que dói, dói, dói

Eu também tenho filhos

Que dói, dói, dói

A cozinheira serviu o macaco num prato enfeitado com arroz, feijão-preto, couve, farofa e mandioca frita.

A velha estalou a língua, sorriu, cortou um pedaço e mordeu.

Na hora de mastigar, o macaco cantou:

Mastiga devagar

Que dói, dói, dói

Eu também tenho filhos

Que dói, dói, dói

A velha estranhou, apertou os olhos mas comeu tudinho. Foi quando deu uma dor de barriga daquelas, pior que rebuliço nas tripas. A mulher levantou, sentou, andou prá lá e prá cá. Não teve jeito, era o macaco pedindo:

- Quero sair.

A velha respondeu:

- Sai pelas orelhas.

- Não posso não, que tem cera - gritou o macaco - Quero sair!

A barriga da mulher doía.

- Sai pelo nariz.

- Tá assim de gosma. Quero sair!

A barriga roncava cada vez mais.

- Sai pela boca.

- Pela boca tem cuspe. Quero sair!

Aí a velha estufou, estufou e pum!

Foi um estouro que se ouviu lá de longe.

E de dentro dela saiu o macaco e mais um bando de macaquinhos, tocando viola, dançando e cantando:

Eu vi a bunda da velha iá, iá

Eu vi a bunda da velha iô, iô.

(AZEVEDO, 2002, p. 26-30) 


\section{9}

\section{Referências bibliográficas}

ACTIS, Beatriz, BARBERIS, Ricardo. Las aulas de literatura: de los textos a las teorías y de la teoría a los textos. Rosario: Homo Sapiens Ediciones, 2013.

ANDRADE, Carlos Drummond. A senha do mundo. Rio de Janeiro: Record, 2002.

AZEVEDO, Ricardo. Histórias que o povo conta. São Paulo: Editora Ática, 2002. p. 26-30.

BAKHTIN, Mikhail. Estética da Criação Verbal. São Paulo: Martins Fontes, 2003.

BAKHTIN, Mikhail. Cultura Popular na Idade Média: o contexto de François Rabelais. São Paulo: Hucitec, 2010.

BHABHA, Homi K. Locais da cultura. In: O local da cultura. Belo Horizonte: Editora da UFMG, [1998] 2005

BARROS, Manoel de. Memórias Inventadas: a infância. São Paulo: Planeta, 2010.

BARROS, Manoel de. Exercícios de ser criança. - Rio de Janeiro: Salamandra, 1999.

BAUMAN, ZYGMUNT. Identidade. Rio de Janeiro: Jorge Zahar, 2005.

BENJAMIN, Walter. Magia e Técnica, Arte e Política. Obras Escolhidas I. São Paulo: Brasiliense, 1994.

BETTELHEIM, Bruno. A psicanálise dos contos de fadas. São Paulo: Paz e Terra, 2007.

BIRMAN, Joel. Leitura crítica: questões sobre recepção. In: Caderno do Simpósio Nacional de Leitura (1994: Rio de Janeiro, RJ). Leitura, saber e cidadania. Centro Cultural Banco do Brasil, 1994.

CARVALHO, Kátia de. O hábito de leitura através da arte. IN: YUNES, Eliana (org); PONDÉ, Glória, Maria Fialho. A Leitura e a formação do leitor: questões culturais e pedagógicas. Rio de Janeiro: Edições Antares, 1984.

COULON, Alain. Etnometodologia. Petrópolis: Vozes, 1995.

ESTÈS, Clarissa Pinkola. O dom da história. Rio de Janeiro: Rocco, 1998. 
FREIRE, Paulo. A importância do ato de ler: em três artigos que se completam. São Paulo: Autores Associados: Cortez, 1989.

FOUCAULT, Michel. A verdade e as formas jurídicas. Rio de Janeiro, Nau Editora, 2001.

FOX, Mem. Guilherme Augusto Araújo Fernandes. São Paulo: BrinqueBook, 1995.

GAGNEBIN, Jeanne Marie. Lembrar, escrever, esquecer. São Paulo: Ed. 34, 2006.

GALEANO, Eduardo. Vozes e Crônicas: Che e outras histórias. São Paulo: Global, 1978.

GALEANO, Eduardo. Las Palabras Andantes. Montevideu, Uruguai: Ediciones Chanchito, 1993.

GALEANO, Eduardo. O Livro dos Abraços. Porto Alegre: L\&PM, 2008.

GREGÓRIO, Francisco. Lembranças Amorosas. São Paulo: Global, 2000.

GUIMARÂES, Ruth (seleção, prefácio, texto e narração). Lendas e fábulas do Brasil. São Paulo: Círculo do Livro, 1989.

GUSMÃO, Denise Sampaio. Por uma Estética da Delicadeza: ressignificando contos e imagens nas roças de Minas. Dissertação de Mestrado. Rio de Janeiro: PUC/RJ, Departamento de Psicologia, 2004.

GUSMÃO, Denise Sampaio. Narrativa, Testemunho e Delicadeza: a Casa de Memória e Cultura do Córrego dos Januários. Orientadora: Solange Jobim e Souza. Rio de Janeiro: PUC/RJ, Departamento de Psicologia, 2009.

HALL, Stuart. A identidade cultural na pós-modernidade. Rio de Janeiro: DP\&A Editora, 2006.

HALL, Stuart. Quem precisa da identidade? In: SILVA, Tomaz Tadeu (org. e trad.). Identidade e diferença: a perspectiva dos estudos culturais. Petrópolis: Vozes, 2000. p. 103-133.

KRAMER, Sonia. Infância, cultura e educação: desafios e possibilidades hoje. In: PAIVA, Aparecida; EVANGELISTA, Aracy; PAULINO, Graça \& VERSIANI, Zélia (Orgs.). No Fim do Século: a diversidade - o jogo do livro infantil. Belo Horizonte: Autêntica, 2003. 
LACERDA, Nair (seleção, introdução e tradução parcial). Fábulas do mundo inteiro. São Paulo: Círculo do Livro, 1990.

LAJOLO, Marisa. Do mundo da leitura para a leitura do mundo. São Paulo: Ática, 1994.

LANDOWSKI, Eric. Presenças do outro. São Paulo: Perspectiva, 1997. MÁRQUEZ, Gabriel Garcia. Cem anos de solidão. Rio de Janeiro: Record, 1996.

NÓBREGA, Nanci. Gonçalves. De livros e bibliotecas como memória do mundo: dinamização de acervos. In: Eliana Yunes. (Org.). Pensar a leitura: complexidade. Rio de Janeiro; São Paulo: Editora PUC-Rio; Edições Loyola, 2002.

QUEIRÓS, Bartolomeu Campos de. Por parte de pai. Belo horizonte: $\mathrm{RHJ}, 1995$.

PRADO, Adélia. Poesia Reunida. São Paulo: Editora Siciliano, 1991.

RICOEUR, Paul. Percurso do reconhecimento. São Paulo: Edições Loyola, 2006.

ROSA, João Guimarães. Grande Sertão: veredas. Rio de Janeiro: Nova Fronteira, 2001.

SANTIAGO, Silviano. O entre-lugar no discurso latino-americano. In: Uma literatura nos trópicos. Rio de Janeiro: Rocco, 2000.

SANTIAGO, Silviano. O cosmopolitismo do pobre: crítica literária e crítica cultural. Belo Horizonte: UFMG, 2004.

SANTOS, Boaventura de Souza. Renovar a teoria crítica e reinventar a emancipação social. São Paulo: Boitempo, 2007.

SOUZA, Maria de Lourdes. Dicionário de Lembranças. Rio de Janeiro: Editora Contemporânea, 1998.

SOUZA, Maria de Lourdes. Família Ribeiro e Januário são pioneiras no município de Inhapim. In: O Inhapim - O jornal da cidade. Fevereiro de 2004, p. 2.

YUNES, Eliana. O que é a leitura: o papel da leitura literária hoje. In: SERRA, Elizabeth D'Angelo (Org). Cartilha: leitura. Rio de Janeiro: FNLIJ, 1988.

YUNES, Eliana. Tecendo um leitor: uma rede de fios cruzados. Curitiba: Aymará, 2009. 
YUNES, Eliana (Org). Pensar a leitura: complexidade. Rio de Janeiro: Ed. PUC-Rio; São Paulo: Loyola, 2002.

YUNES, Eliana. Políticas públicas de leitura: modos de fazer. In: Miguel Rettenmaier; Tania M. Kuchenbecker Rösing (org). Questões de Leitura. Passo Fundo: UPF, 2003.

TEZZA, Cristovão. Sobre o autor e o herói. In: FARACO, C. A., TEZZA, Cristovão, e CASTRO, G. Diálogos com Bakhtin. Curitiba: Ed. da UFPR, 1996.

VELHO, Gilberto. Observando o familiar. In: Edson de Oliveira Neves (org). A aventura sociológica: objetividade, paixão, improviso e método na pesquisa social. Rio de Janeiro: Zahar Editores, 1978.

VOLOSHINOV, V. N.; BAKHTIN, Mikhail. Marxismo e filosofia da linguagem. São Paulo: Hucitec, 1079.

\section{1 Referências eletrônicas}

ACTIS, Beatriz. La Pilaraña ataca por primera ¿y última? vez. Disponível em http://bibliopequeitinerante.blogspot.com/2012/11/cuentola-pilarana-ataca-por-primera-y.html . Acessado em 20/02/2014.

BATISTA, Francisco das Chagas. Antônio Silvino: vida, crimes e julgamento. Disponível em:

http://www3.universia.com.br/conteudo/literatura/antoniosilvinovidacrimes ejulgamento.pdf. Acessado em 28/01/2014.

Cátedra UNESCO de Leitura PUC-Rio. Disponível em: http://www.catedra.puc-rio.brl. Acessado em 24/02/2014.

CONAPIB (Comisión Nacional de Bibliotecas Populares). Disponível em:. http://www.conabip.gob.ar/vpes/491 Acessado em 11/02/2014.

Biblioburro (Vídeo). Disponível em: http://www.youtube.com/watch?v=tsHyN9zj8 o\#t=0 . Acessado em 25/02/2014.

El Biblio-Burro, acercando los libros para enseñar a leer. Disponível em http://optimista.net/biblioburro/ . Acessado em 24/02/2014.

"Quando acaba a Comunidade nenhuma cultura sobrevive". Coroação de Reis Congo. Filme realizado pelos pesquisadores Sérgio Bairon (Líder do CEDIPP - Centro de Comunicação Digital e Pesquisa Partilhada - ECA USP - BR e Pesquisador do Diversitas/USP) e José da Silva Ribeiro (Universidade Aberta - $\quad$ PT) Disponível em: 
http://www.youtube.com/watch?v=TDBkagSUx0M. Acessado em 08/12/2012. Acessado em 24/02/2014.

Filhos da Terra: Disponível em: ://www.flickr.com/photos/simonesattler/4709251271/in/photostream/. Acessado em 20/02/1014.

MACHADO, Antônio. Proverbios y cantares XXIX (trecho de poema): Disponível em http://pt.wikipedia.org/wiki/Antonio Machado. Acessado em 09/08/2014.

MORAES, Maria Candida \& LA TORRE, Saturnino de. Sentipensar sob o olhar autopoiético: Estratégias para reencantar a educação. Disponível

em http://www.ub.edu/sentipensar/pdf/sentipensar autopoietico.pdf Acessado em 20/02/2014.

Plan Nacional de Lectura/Argentina. Disponível em: http://www.planlectura.educ.ar/ . Acessado em 20/02/2014.

PROLER (Programa Nacional de Incentivo à Leitura). Disponível em: http://www.bn.br/proler/ . Acessado em 20/02/2014.

PRIETO Benita. Disponpivel em http://benitaprieto.blogspot.com.br/2010_05_01_archive.html. Acessado em 20/02/2014.

VOLOSHINOV, V. N.; BAKHTIN, Mikhail. Discurso na vida discurso na arte. Acessível em: http://pt.scribd.com/doc/96529004/M-BakhtinDiscurso-Na-Vida-Discurso-Na-Arte. Acessado em 28/10/2012. 